Instituto de Agroquímica y Tecnología de Alimentos

(IATA-CSIC)
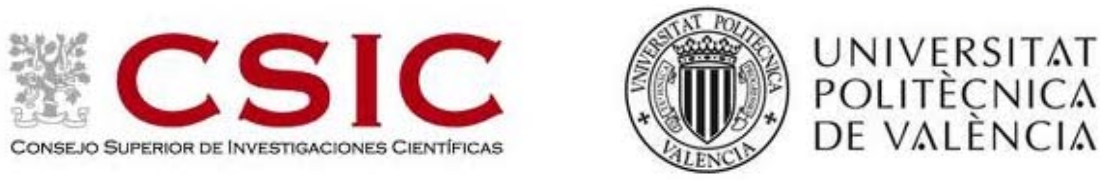

\title{
Desarrollo y caracterización de polímeros activos hidrofílicos para el envasado de alimentos
}

\author{
TESIS DOCTORAL \\ Directores: \\ Rafael Gavara Clemente \\ Pilar Hernández Muñoz
}

Ana Carolina López de Dicastillo Bérgamo

Valencia, Junio 2011 
Dr. Rafael Gavara Clemente, Profesor de Investigación del Consejo Superior de Investigaciones Científicas (CSIC) en el Instituto de Agroquímica y Tecnología de Alimentos (IATA) y Dra. Pilar Hernández Muñoz, científica titutlar en el mismo instituto

\section{CERTIFICAN}

Que la presente memoria "Desarrollo y caracterización de polímeros activos hidrofílicos para el envasado de alimentos" constituye la tesis doctoral de Dña. Ana Carolina López de Dicastillo Bergamo. Asimismo certifican haber dirigido y supervisado tanto los distintos aspectos del trabajo como su redacción.

Y para que conste a los efectos oportunos, firmamos la presente en Valencia a 5 de Mayo de 2011.

Fdo. R.Gavara

Fdo. P.Hernández Muñoz 


\section{DESARROLLO Y CARACTERIZACIÓN DE POLÍMEROS ACTIVOS HIDROFÍLICOS PARA EL ENVASADO DE ALIMENTOS}

\section{RESUMEN}

En esta tesis se ha abordado el desarrollo de dos sistemas de envasado activo de interés, cuyos objetivos son el control de los procesos de oxidación en los alimentos envasados y la eliminación de sustancias indeseables presentes en el alimento $u$ originadas durante el almacenamiento.

Como materiales base para el desarrollo de estos sistemas activos se proponen los polímeros hidrofílicos EVOH y $\mathrm{PVOH}$, ampliamente utilizados en el diseño de envases por sus propiedades barrera. El carácter hidrofílico de estos polímeros y la presencia de grupos polares en la matriz proporciona una adecuada interacción con los agentes activos incorporados y aporta un buen mecanismo de iniciación de la actividad para su utilización tecnológica.

Para el estudio de la reducción de los procesos oxidativos se ha trabajado con sustancias antioxidantes naturales (ácido ascórbico, ácido ferúlico, catequina, quercitina y extracto de té verde), incorporadas en la matriz polimérica mediante técnicas de extrusión (con EVOH 44) y de disolución/evaporación o "casting" (con EVOH 29). Se han caracterizado las propiedades físico-químicas de interés de los materiales desarrollados, evaluando el efecto de la incorporación de los antioxidantes en el polímero y del proceso de obtención de las películas. Se ha estudiado la liberación de los antioxidantes a distintos simulantes alimentarios y se ha comprobado la actividad antioxidante de las películas en distintas matrices alimentarias como cacahuetes, aceite de girasol y pescado graso. Todos los materiales presentaron una significativa actividad antioxidante, siendo la liberación de los agentes activos proporcional a la concentración de antioxidante presente en la película y a su solubilidad en el medio simulante empleado. 
En general, las propiedades del polímero importantes para una aplicación como envase, térmicas o barrera, no se vieron afectadas de forma relevante con la incorporación de los antioxidantes.

El estudio de la eliminación de sustancias indeseables presentes en el alimento $\mathrm{u}$ originadas durante el almacenamiento se ha centrado en el control de colesterol en leche y de los volátiles resultado de la oxidación responsables de olor desagradable, mediante la formación de complejos con $\beta$-ciclodextrinas inmovilizadas en matrices de EVOH y $\mathrm{PVOH}$.

Las películas de EVOH con ciclodextrinas obtenidas por extrusión presentaron pequeñas discontinuidades, sin cambios importantes en sus propiedades térmicas y con valores de permeabilidad a gases y al vapor de agua ligeramente superiores, debido a un aumento en el volumen libre de la matriz. Las películas con mayor concentración de ciclodextrinas presentaron mayor actividad secuestradora de colesterol y de sustancias resultantes de la oxidación de cacahuetes. Las películas de $\mathrm{PVOH}$ con ciclodextrinas se obtuvieron por "casting". Para evitar la redisolución del polímero y aumentar la inmovilización de la ciclodextrina, el polímero se entrecruzó con glioxal. Los materiales obtenidos fueron estables, con propiedades similares a las del $\mathrm{PVOH}$ original. En ensayos con alimento real, se consiguió una reducción significativa de la concentración de colesterol en leche entera. 


\section{DESENVOLUPAMENT I CARACTERITZACIÓ DE POLÍMERS ACTIUS HIDROFÍLICS PER A L'ENVASAMENT D’ALIMENTS}

\section{RESUM}

En aquesta tesi s'ha abordat el desenvolupament de dos sistemes d'envasat actiu d'interès, els objectius dels quals són el control dels processos d'oxidació en els aliments envasats i l'eliminació de substàncies indesitjables presents en l'aliment o originades durant l'emmagatzematge.

Com materials base per al desenvolupament d'aquests sistemes actius es proposen els polímers hidrofílics EVOH i PVOH, àmpliament utilitzats en el disseny d'envasos per les seves propietats barrera. El caràcter hidrofílic d'aquests polímers i la presència de grups polars en la matriu proporciona una adequada interacció amb els agents actius incorporats i aporta un bon mecanisme d'iniciació de l'activitat per a la seva utilització tecnològica.

Per a l'estudi de la reducció dels processos oxidatius s'ha treballat amb substàncies antioxidants naturals (àcid ascòrbic, àcid ferúlic, catequina, quercitina i extracte de te verd), incorporades en la matriu polimèrica mitjançant tècniques de extrusió (amb EVOH 44) o de dissolució/evaporació o "casting" (amb EVOH 29). S'han caracteritzat les propietats físic-químiques d'interès dels materials desenvolupats, avaluant l'efecte de la incorporació dels antioxidants en el polímer i del procés d'obtenció de les pel•lícules. S'ha estudiat l'alliberament dels antioxidants a distints simulants alimentaris i s'ha comprovat l'activitat de les pel-lícules en diferents matrius alimentàries com cacauets, oli de girasol i peix gras. Tots els materials van presentar una significativa activitat antioxidant, sent l'alliberament dels agents actius proporcional a la concentració d'antioxidant present en la pel-lícula i a la seva solubilitat en el mitjà simulant empleat. En general, les propietats del polímer importants per a una aplicació com envàs, tèrmiques o barrera, no es van veure afectades de forma rellevant amb la incorporació dels antioxidants. 
L'estudi de l'eliminació de substàncies indesitjables presents en l'aliment o originades durant l'emmagatzematge s'ha centrat en el control de colesterol en llet i dels volàtils resultat de l'oxidació responsables d'olor desagradable, mitjançant la formació de complexos amıß -ciclodextrines immobilitzades en matrius de EVOH i PVOH.

Les pel-lícules de EVOH amb ciclodextrina obtingudes per extrusió van presentar petites discontinuïtats, sense canvis importants en les seves propietats tèrmiques $\mathrm{i}$ amb valors de permeabilitat a gasos $\mathrm{i}$ al vapor d'aigua lleugerament superiors, a causa de un augment en el volum lliure de la matriu. Les pel-lícules amb major concentració de ciclodextrina van presentar major activitat atrapadora de colesterol i de substàncies resultants de l'oxidació de cacauets. Les pel-lícules de $\mathrm{PVOH}$ amb ciclodextrines es van obtenir per "casting". Per a evitar la redisolució del polímer i augmentar la immobilització de la ciclodextrina, el polímer es va entrecreuar amb glioxal. Els materials obtinguts van ser estables, amb propietats similars a les del PVOH original. En assajos amb aliment real, es va aconseguir una reducció significativa de la concentració de colesterol en llet sencera. 


\title{
DEVELOPMENT AND CHARACTERIZATION OF HYDROPHILIC ACTIVE POLYMERS FOR FOOD PACKAGING APPLICATIONS
}

\begin{abstract}
This PhD dissertation thesis has been focused on two interesting active packaging systems which aim has been the control of oxidation processes in packaged food and the retention of undesired components initially present in food or developed during storage.

Two hydrophilic polymers $\mathrm{EVOH}$ and $\mathrm{PVOH}$, widely used in packaging design to provide barrier properties have been used as polymeric matrices for these active packaging systems. The hydrophilic nature of these polymers and the presence of polar groups impart an adequate interaction with the added agents and provide a triggering mechanism of activity very useful for the technological application.

To delay food deterioration caused by oxidative processes, natural antioxidant substances (ascorbic acid, ferulic acid, catechin, quercetin and green tea extract) were incorporated to the polymer by melt-mixing during extrusion (EVOH 44) or by solution/evaporation (EVOH 29). The physicochemical properties of the materials developed were characterized, evaluating the effect of the addition of the antioxidants and the effect of the type of processing. The release of these agents into various food simulants was fully characterized and the activity in the protection of food products was confirmed in fried peanuts, sunflower seed oil and brined sardines. All materials presented a significant antioxidant activity, the agent release being dependent on the concentration of the additive and their solubilities in the simulants. In general, the functional properties of the polymers as materials for the design of food packages were not relevantly affected by the incorporation of the antioxidants.
\end{abstract}


Scavenging activity of undesired components was focused on the control of cholesterol in whole milk and the control of byproducts produced by fat oxidation through the formation of inclusion complexes with cyclodextrins immobilized in $\mathrm{EVOH}$ and $\mathrm{PVOH}$ films.

Cyclodextrin containing EVOH films obtained by extrusion were mainly transparent with some discontinuities caused by accumulation of the agent. The incorporation of the oligosaccharides produced a slight increase in the permeability to gases and vapors owing to an increase in free volume. Films presented a significant effect on cholesterol content of milk and on the accumulation of aldehydes produced by oxidation of packaged peanuts. Cyclodextrin containing $\mathrm{PVOH}$ films obtained by casting received a crosslinking treatment with glyoxal to improve the immobilization of the cyclodextrin and the solution of the polymer. Tests with milk proved that the films were active as scavengers of cholesterol. 


\section{INTRODUCCIÓN}

\subsection{ENVASADO ACTIVO DE ALIMENTOS}

Durante muchos años el envase cumplía tres funciones básicas: contener, conservar y proteger al producto envasado. Con el paso del tiempo, esas funciones tradicionales se han visto ampliadas con otras muchas exigencias como que presenten comportamientos físico-químicos específicos en relación con el producto contenido, que se adecúen a los requisitos de la moderna distribución comercial, que cumplan con las nuevas reglamentaciones y legislaciones relacionadas con los alimentos o con el medio ambiente, que sus costos sean adecuados al producto final y, tanto más, que presenten un cierto atractivo para captar la atención del consumidor.

En ese contexto de exigencias y continua innovación, el nuevo paradigma de los envases es su comportamiento inteligente, entendiendo como tal la participación activa en el mantenimiento o incluso mejora de la calidad del alimento envasado (Catalá y Gavara, 2001). Surgen así los conceptos de "envase activo" y "envase inteligente", términos que se refieren a formas de actuación de los envases, que van más allá del uso convencional de actuar como barrera pasiva aisladora del medio exterior y con mínima incidencia sobre el producto envasado (Brody, 2001a). El envase activo, por el contrario, trata de potenciar $y$ aprovechar las interacciones del sistema alimento//envase//entorno actuando de forma coordinada para mejorar la salubridad y la calidad del alimento envasado y aumentar su vida útil. De esta forma, el envasado activo, o envasado con envases activos, puede ser considerado como una tecnología emergente de conservación de alimentos (Rooney, 1995; Vermeiren et al., 1999; Ozdemir y Floros, 2004).

Para el desarrollo de envases activos se han empleado todo tipo de materiales, pero son los plásticos con los que estas tecnologías encuentran sus mejores posibilidades. 
En las últimas décadas, el uso de materiales plásticos para el envasado de alimentos ha aumentado enormemente debido a sus ventajas sobre los materiales utilizados tradicionalmente, como el vidrio o la hojalata. Se dispone en la actualidad de una amplia variedad de polímeros con distintas composiciones que además pueden mezclarse o combinarse, lo que ofrece una gran versatilidad de propiedades funcionales y permite adoptar el diseño del envase más conveniente para cada producto. Otras características relevantes son su bajo costo, su termosellabilidad, su facilidad de impresión, que pueden ajustarse a una variedad ilimitada de tamaños y formas, además de unas propiedades ópticas adaptables a las necesidades del producto (Catalá y Gavara, 2001). Los materiales poliméricos han propiciado que los envases se encuentren en una evolución continua, abriendo nuevas fronteras y modificando costumbres y usos establecidos y aparentemente arraigados, pero sobre todo han sido la base para el desarrollo de nuevas tecnologías. Los materiales poliméricos se adecuan particularmente a las necesidades del envasado activo y son la base para el desarrollo de esta nueva tecnología (Hernández et al., 2000; López-Rubio et al., 2004).

Ciertamente el concepto de envasado activo no es totalmente novedoso, se encontraba ya en las prácticas de manejo de alimentos de algunas poblaciones indígenas de países cálidos, las cuales recubrían determinados productos tradicionales con ciertas hojas y, de este modo, el "envase", en este caso las hojas, aportaban enzimas y otros compuestos tales como agentes antimicrobianos o aromas que, además de mejorar las propiedades organolépticas al producto, prolongaban el tiempo de conservación.

En la actualidad, con la redefinición del concepto de envase activo y su aceptación por parte de las legislaciones sanitarias internacionales, se puede pensar en diseñar envases y tecnologías de envasado a medida de las necesidades del mercado consumidor y de los diferentes productos, teniendo en cuenta que cada alimento tiene un mecanismo específico de deterioro (Restuccia et al., 2010). 


\subsubsection{Características básicas de los envases activos}

La base de la utilización de los materiales poliméricos para el desarrollo de envases activos es el aprovechamiento positivo de los procesos de transferencia de masa que tienen lugar en estos materiales (Dury-Brun et al., 2007). Los materiales poliméricos no son totalmente inertes y se producen interacciones con el alimento o la atmósfera que comprenden el transporte de gases, vapor de agua y otras moléculas de bajo peso molecular como componentes del aroma alimentario, o residuos y aditivos del material de envase, que pueden producir cambios químicos, nutricionales y sensoriales en el alimento envasado (Gavara y Catalá, 2002).

La Figura 1 describe esquemáticamente los procesos de transferencia de masa que se establecen en el sistema entorno//envase//alimento: i) permeación o transferencia de componentes volátiles (componentes del aroma, vapor de agua y gases) a través del polímero, tanto del exterior al interior como viceversa; ii) sorción o retención de componentes del alimento en las paredes del envase, y iii) migración o liberación de componentes volátiles y no volátiles del material polimérico al alimento (Dury-Brun et al., 2007; Han, 2005; Lee et al., 2008).
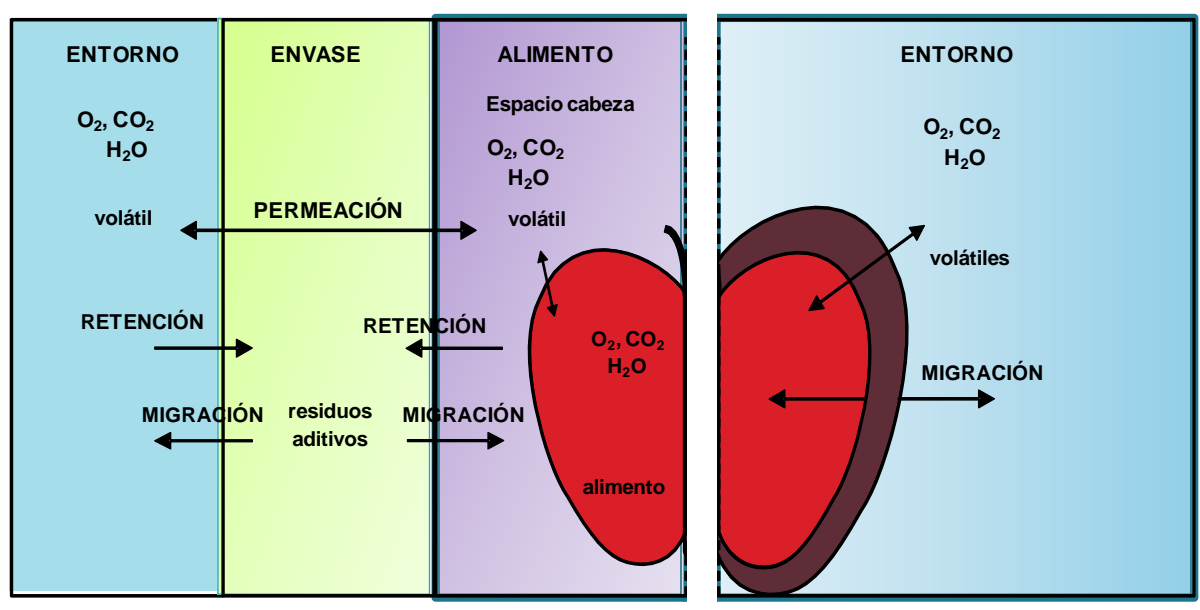
Figura 1. Procesos de transferencia de masa en el sistema producto//envase//entorno. A la izquierda un envase, a la derecha un recubrimiento alimentario.

Estos procesos de transferencia de masa se consideran aspectos negativos de los materiales plásticos porque pueden comprometer la calidad y seguridad del alimento envasado. Sin embargo, también es posible sacar provecho de los mismos en beneficio del producto envasado, haciendo un aprovechamiento positivo de estos mecanismos como base para el desarrollo de envases activos.

Las diversas tecnologías de envasado activo incorporan en el envase algún agente que debe retener, reaccionar o liberar un componente determinado cuya presencia o ausencia es crítica para mantener la calidad del producto envasado. Por tanto, es necesario que dicho componente se intercambie entre el alimento y el envase con una cinética adecuada.

Desde el inicio del desarrollo de estas tecnologías, la forma de introducción del elemento activo ha sido la utilización de una pequeña bolsa conteniendo dicho principio, depositada en el interior del envase junto con el producto envasado (Smith et al., 1995). La bolsa se construye con un material polimérico con baja capacidad barrera frente a la sustancia que se desea retener o liberar para permitir su acción activa sobre el producto. Por supuesto, deben usarse materias activas que no pongan en peligro la salubridad del producto envasado. Así, se comercializan bolsitas con polvo de hierro para secuestrar oxígeno, con bicarbonato sódico para liberar dióxido de carbono, con permanganato potásico y/o zeolitas para adsorber etileno, etc. Ésta ha sido la forma convencional de actuación de muchos sistemas activos y aún es ampliamente utilizada, aunque presenta reconocidos inconvenientes, entre los que destaca el posible rechazo del consumidor al encontrar un objeto extraño y con mensajes de advertencia en contacto con el alimento que va a consumir.

En la actualidad, los desarrollos se encaminan a la sustitución de la bolsita con el elemento activo por la introducción de dicho elemento en la propia estructura del envase, por lo que el material debe tener las características 
adecuadas para permitir la acción del agente con el producto envasado o su atmósfera circundante sin alterar otras propiedades fundamentales del envase por la presencia y actuación del compuesto activo (Han, 2005; López-Rubio et al., 2004). Los componentes activos pueden estar presentes en el material de envase, bien en el interior del mismo formando parte de su composición, o bien depositado sobre su superficie, como recubrimiento o "coating" (Figura 1). Ésta es una forma más atractiva para el consumidor, que así no encuentra nada extraño en el interior del envase que pueda llamarle la atención y hacerle dudar sobre la inocuidad y seguridad del alimento que va a consumir y, así mismo, simplifica la tecnología de envasado al eliminar la operación de introducción del sistema activo en el envase.

Se han propuesto muy diversas formas de envases activos para el control de la mayor parte de problemas de deterioro o alteración de los alimentos. Entre los envases activos comerciales cabe destacar los secuestradores de oxígeno, que se están empleando para eliminar el oxígeno residual del espacio de cabeza en los envases y reducir así los procesos de deterioro causados por la presencia de este gas, como son el crecimiento microbiano, la generación de olores y sabores desagradables debido a la oxidación o las pérdidas en el valor nutricional del alimento. Los compuestos usualmente utilizados como secuestradores de oxígeno son aquellos capaces de reaccionar con éste reduciendo su concentración. El óxido de hierro es el secuestrador más comúnmente utilizado (Kerry et al., 2006), pero también se utilizan el ácido ascórbico, sulfitos, algunas poliamidas, catecoles e incluso enzimas como glucosa oxidasa. Normalmente se incorporan al envase incluidos en pequeñas bolsas o etiquetas junto con el producto envasado, pero los últimos desarrollos tienden a integrarlos en la propia estructura del envase; Farkas (1998) incorporó hierro en polvo en polietileno de baja densidad y Cryovac Corporation ha desarrollado una película secuestradora de oxígeno capaz de superar los efectos negativos de los materiales que contienen hierro, obteniendo un material en el que estas sustancias son 
invisibles al ojo del consumidor, y además su actividad se inicia através de la radiación con luz ultravioleta (Farkas, 1998; López-Rubio et al., 2004).

Otros desarrollos de materiales activos de interés permiten controlar la concentración de dióxido de carbono o etileno en el envasado en atmósfera modificada de frutas y hortalizas, o la humedad -condensación de agua- en el interior del envase de carnes o productos vegetales frescos (Labuza, 1996). La adición de $\mathrm{CO}_{2}$ permite reducir el crecimiento microbiano aeróbico que se da en algunos alimentos como la carne, así como reducir la velocidad de respiración de alimentos vegetales frescos. Multiform Desiccants Incorporated ha desarrollado una bolsita secuestradora de $\mathrm{CO}_{2}$ que contiene óxido cálcico y un agente como gel de sílice, donde el agua se adsorbe. De esta forma, el agua reacciona con el óxido y produce hidróxido de calcio que reacciona con el $\mathrm{CO}_{2}$ formando carbonato cálcico. El gel de sílice es el compuesto más comúnmente utilizado como agente desecante, ya que no es tóxico ni corrosivo. Los adsorbedores de etileno también son muy interesantes, ya que este gas actúa como una hormona durante la maduración de frutas y hortalizas y cataliza el envejecimiento, induce el florecimiento, acelera el reblandecimiento $y$, en definitiva, reduce el tiempo de vida útil, por lo cual es muy importante poder eliminarlo si se encuentra en el interior del envase; los elementos activos más usuales utilizados con este fin son permanganato de potasio, zeolitas o carbón activo con la participación potencial de catalizadores metálicos (paladio).

También se está estudiando la introducción de diferentes aditivos para usos muy específicos como eliminación de aromas y sabores extraños, control de colesterol y de lactosa en leches, etc., que pueden tener gran interés práctico (Rooney, 1995; Vermeiren et al., 1999; Hotchkiss, 2000; Brody et al., 2001b).

Reducir el deterioro microbiológico mediante la incorporación de agentes microbicidas en los plásticos, que se liberan lentamente en el alimento, es otro de los grandes objetivos del envasado activo. El envasado antimicrobiano limita o inhibe el crecimiento de los microorganismos gracias a la prolongación de la fase de latencia, a la reducción de la tasa de crecimiento y/o a la 
reducción de los recuentos microbiológicos. Las sustancias antimicrobianas añadidas al material de envasado migran al alimento de forma gradual durante el almacenamiento y distribución del mismo (Appendini y Hotchkiss, 2002; Suppakul et al., 2003). El envasado antimicrobiano es efectivo para evitar o minimizar la contaminación superficial de los alimentos, de aquí el interés de su aplicación en productos cárnicos listos para el consumo en los que, debido a la manipulación post-procesado, la contaminación ocurre principalmente en la superficie. Algunos agentes antimicrobianos usados en el envasado de alimentos son ácidos orgánicos, sulfitos, nitratos, alcoholes y antimicrobianos naturales. Las sustancias antimicrobianas utilizadas en el envasado de alimentos que pueden migrar hacia el alimento son considerados aditivos alimentarios, por lo que deben cumplir la legislación vigente (Real Decreto 142/2002). Debido a que la alteración microbiológica es una de las principales razones en el deterioro de los alimentos, en los últimos años ha crecido enormemente el interés por estos sistemas, dando lugar al desarrollo de varios materiales activos que ya son comerciales y además han sido desarrollados por grupos y empresas españolas (López et al., 2007; GarcesLardies y Nerín, 2008; Gutiérrez et al., 2009).

Sin duda, con las diferentes formas de actuación de los envases activos en desarrollo la tecnología de envasado activo presenta excelentes perspectivas de futuro para la mejora de la calidad y aumento de la vida útil de los alimentos industrializados.

En los trabajos que se presentan en esta memoria se ha abordado el desarrollo de dos sistemas activos de interés, cuyos objetivos son: a) limitar y controlar los procesos de oxidación de alimentos mediante la incorporación de antioxidantes naturales en la matriz polimérica que constituye el material de envase, y b) retener y eliminar sustancias indeseables, como son el colesterol y compuestos volátiles formados en los procesos de oxidación a partir de la formación de complejos con ciclodextrinas, incorporadas previamente en la matriz polimérica. 
En el diseño de materiales activos deben tenerse en cuenta diversos factores para hacer viable su aplicación industrial. El material polimérico debe ser fácilmente procesable por tecnologías convencionales, ya sea por un procesado mecanotérmico (extrusión, inyección) o aplicado como recubrimiento en el material de envase, sin que afecte de forma apreciable su procesado. Las propiedades del polímero, a su vez, no han de verse comprometidas con la incorporación del agente activo, especialmente si éstas son fundamentales en el diseño del envase. Por otra parte, el agente activo debe retener su actividad una vez incorporado en el polímero y debe poder actuar con una cinética adecuada para que ejerza su actividad de forma óptima, pero sin iniciarla hasta el momento del envasado del producto, evitando así que ésta se haya perdido cuando el material vaya a ser usado, por lo que se requiere algún mecanismo de iniciación en el momento de entrar en contacto con el alimento en el envasado.

En general, cuando el alimento a envasar no requiere particulares exigencias de barrera a gases y vapores, las poliolefinas son los materiales poliméricos más utilizados, pero cuando se exige mayor impermeabilidad del material de envase, las alternativas son poliésteres o poliamidas, y sobretodo estructuras multicapa que incluyen materiales de alta barrera, como son el aluminio, recubrimientos metalizados, el PVdC, el poli(alcohol vinílico) ( $\mathrm{PVOH}$ ) o los copolímeros de etileno-alcohol vinílico $(\mathrm{EVOH})$. Estos dos últimos polímeros hidrofílicos son los materiales de base para el desarrollo de los trabajos que se presenta en esta memoria.

Los envases activos se han ido introduciendo comercialmente y ya son muchos y muy diversos los usos pricipalmente en Australia y Japón, donde comenzó su desarrollo ya en la década de los años 80. En Europa la introducción comercial de estos envases no ha sido posible hasta fechas recientes debido a restricciones legislativas, así como la falta de conocimientos sobre la aceptación del consumidor, la eficacia de los sistemas y el impacto económico y medioambiental (López-Rubio et al., 2004). 


\subsubsection{Legislación de envases activos}

A primeros de diciembre de 2004 entró en vigor un nuevo reglamento comunitario que regula los materiales y objetos destinados a entrar en contacto con los alimentos, el Reglamento CE 1935/2004 del Parlamento Europeo y del Consejo, de 27 de octubre de 2004, sobre los materiales y objetos destinados a entrar en contacto con alimentos y por el que se derogan las Directivas 80/590/CEE y 89/109/CEE (CE 2004). Este Reglamento tiene como finalidad garantizar un elevado nivel de protección de la salud humana y de los intereses de los consumidores, y establece como principios básicos que los materiales y objetos destinados al contacto con los alimentos habrán de estar fabricados de conformidad con las buenas prácticas de fabricación para que, en las condiciones normales o previsibles de empleo, no transfieran sus componentes a los alimentos en cantidades que puedan: a) representar un peligro para la salud humana, b) provocar una modificación inaceptable de la composición de los alimentos, o c) provocar una alteración de las características organolépticas de éstos.

Establece este Reglamento las disposiciones generales obligatorias para todo tipo de materiales y objetos y remite a futuros reglamentos específicos para cada material. En ese marco se publicó el año 2009 un reglamento específico para los materiales activos e inteligentes, Reglamento CE 450/2009 de la Comisión de 29 de mayo de 2009 sobre materiales y objetos activos inteligentes destinados a entrar en contacto con alimentos (CE 2009), que establece las exigencias que deben cumplir estos materiales para la comercialización en el mercado comunitario.

El citado reglamento define como envase activo aquel destinado a prolongar la vida útil o a mantener o mejorar el estado de los alimentos envasados. Los envases activos deben estar diseñados para incorporar intencionadamente componentes que liberan o absorben sustancias del alimento envasado o en su entorno. También se define en el ámbito de aplicación del citado 
reglamento, el envase inteligente, que es aquel que controla el estado del alimento envasado o de su entorno.

De acuerdo con este Reglamento podrán introducirse en el mercado los materiales y objetos activos e inteligentes siempre que: a) sean adecuados y eficaces para el uso previsto, b) cumplan los requisitos generales del Reglamento 1935/2004, y c) cumplan los requisitos específicos establecidos por este Reglamento.

Las sustancias que pueden incorporarse a cualquier sistema activo o inteligente deberán estar incluidas en una futura lista comunitaria de sustancias autorizadas. La lista comunitaria deberá especificar las características de las sustancias, las funciones a cumplir y las condiciones de uso del material u objeto al que se añade o incorpora la sustancia. Por otra parte, la sustancia activa que se libere en un alimento deberá considerarse un ingrediente de acuerdo con el artículo 6 apartado 4 letra a) de la Directiva 2000/13/CE relativa a la aproximación de las legislaciones de los estados miembros en materia de etiquetado y publicidad de los productos alimenticios (CE 2000). Los sistemas activos que no están integrados en el envase, como por ejemplo los sobres y/o bolsas que contienen la sustancia activa, deben incluir obligatoriamente las palabras 'no ingerir'. Por último y en relación a lo dispuesto en el reglamento de materiales en contacto con alimentos, las empresas que fabriquen este tipo de materiales activos e inteligentes deben realizar una declaración de conformidad que registre la aptitud alimentaria de estos productos.

\subsection{MATERIALES HIDROFÍLICOS PARA ENVASES}

Los polímeros hidrofílicos son aquellos que contienen grupos polares o grupos funcionales cargados, presentando cierta afinidad al agua. En general, presentan unas excelentes propiedades barrera frente a gases y compuestos orgánicos en seco, característica básica para asegurar la inmovilización de agentes activos. Sin embargo, todos ellos son materiales sensibles a la 
humedad y en presencia de ambientes de humedad relativa elevada sufren un deterioro en sus propiedades muy significativo, con pérdidas de permeabilidad al oxígeno que pueden superar los tres órdenes de magnitud (López-Rubio et al., 2003; López-Rubio et al., 2005). Esta sensibilidad, que puede suponer un problema cuando se requiere gran capacidad barrera frente al intercambio de gases, puede ser aprovechada para el desarrollo de sistemas de envasado activo, ya que la puesta en contacto del material que incorpora el agente activo con alimentos de humedad relativa elevada, puede iniciar la liberación del agente, produciendo así el efecto de protección del alimento para el que se haya diseñado.

Como se indicaba anteriormente, es de suma importancia que el material activo disponga de un mecanismo de iniciación para dar lugar a su actividad, evitando así la actuación del agente activo antes del envasado del producto. Los materiales hidrofílicos pueden ser adecuados para formar parte de envases activos ya que, debido a su naturaleza hidrofílica, cuando entren en contacto con el alimento su matriz polimérica se hincha debido a la humedad, permitiendo la liberación del compuesto activo.

El PVOH y el EVOH, han sido los polímeros hidrofílicos seleccionados para realizar este proyecto debido a sus excelentes propiedades para el desarrollo y diseño de envases alimentarios.

\subsubsection{EVOH y PVOH}

El poli (alcohol vinílico) o alcohol polivinílico, PVOH, cuya estructura se observa en la Figura 2, es un polímero biodegradable e hidrófilo, con múltiples usos en la preparación de materiales plásticos, en la industria textil y en la industria farmacéutica. Se obtiene a partir de la hidrólisis total o parcial del poliacetato de vinilo, PVA, dependiendo del grado de hidrólisis las propiedades químicas y físicas del polímero final. El material resultante es atáctico pero debido a que el tamaño del grupo hidroxilo es suficientemente pequeño, el polímero presenta una estructura semicristalina, tanto mayor 
cuanto mayor sea el grado de hidrólisis. Presenta fuertes fuerzas intermoleculares por puente de hidrógeno entre los grupos $-\mathrm{OH}$ de diferentes cadenas lo que confiere un elevado grado de cohesión y una reducción del volumen libre. Tiene excelentes características para formar películas que presentan una buena resistencia a la tracción, flexibilidad y excelente barrera a oxígeno y otros gases permeantes, debido a las mencionadas cristalinidad y cohesión interna. Es un polímero difícil de procesar en fundido, ya que estas fuerzas son tan intensas que su temperatura de degradación se encuentra por debajo de su temperatura de fusión. Es soluble en agua y sensible a la humedad y ofrece excelente resistencia a grasas, aceites y disolventes. Tanto su solubilidad como otras propiedades, son influenciadas por su grado de hidrólisis y su peso molecular. A menor grado de hidrólisis, es decir mayor número de grupos acetato, la solubilidad al agua es menor, así como sus propiedades barrera (Brown, 1992; Hernández et al., 2000). Debido a su difícil procesado y su extrema sensibilidad al agua, el PVOH tiene pocas aplicaciones como material de envase. Se emplea como excipiente de medicamentos, adhesivo, formador de películas, lubricante en lentes de contacto, barrera al dióxido de carbono en botellas PET, y como recubrimientos en papel o películas solubles en agua, siendo esta última la principal aplicación en el campo de envases de alimentos.

El copolímero de etileno y alcohol vinílico, EVOH, cuya estructura química se da en la Figura 2, es un polímero que se caracteriza principalmente por su baja permeabilidad a gases y aromas y sus excelentes propiedades físicas y ópticas, aunque debido a su carácter hidrófilo, es muy sensible al agua y sus propiedades barrera se ven muy afectadas por la humedad (Aucejo, 2000; Aucejo et al., 2000).<smiles>CCC(C)C(O)CC</smiles>

PVOH

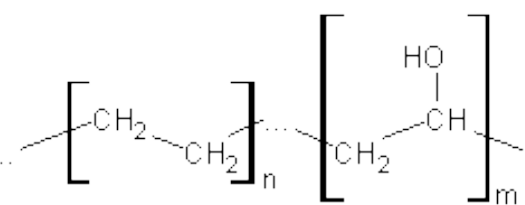

EVOH 
Figura 2. Estructura de los monómeros de los polímeros hidrofílicos, poli (alcohol vinílico), PVOH, y copolímero etileno-alcohol vinílico, EVOH.

El EVOH se obtiene a partir de la hidrólisis del copolímero de etileno y acetato de vinilo (EVA). Las cadenas de EVA están formadas por las unidades constitucionales de ambos monómeros distribuidas estadísticamente. EI copolímero EVOH se clasifica según su fracción molar de etileno, siendo las formulaciones más comúnmente utilizadas las que contienen una fracción molar de etileno de 26 a 48\% (Hernández et al., 2000).

Estos copolímeros combinan el carácter hidrofóbico del etileno y el comportamiento hidrofílico del alcohol vinílico. Las excelentes propiedades barrera de este copolímero se derivan de la presencia en su estructura de grupos hidroxilo que le confieren una elevada cohesión intermolecular, reduciendo el volumen libre entre las cadenas disponibles para el intercambio de gases. Sin embargo, los grupos - $\mathrm{OH}$ también son responsables de la naturaleza hidrofílica del polímero, de manera que a mayor porcentaje de monómero alcohol vinílico, mayor influencia de la humedad en las propiedades barrera y peor procesabilidad tendrá el copolímero (Iwanami y Hirai, 1983). Por otra parte, altos contenidos de etileno disminuyen su temperatura de procesamiento.

A pesar de ser un material sintético que procede del petróleo, tiene las ventajas de ser biodegradable y biocompatible (Oyane et al., 2006). A diferencia del $\mathrm{PVOH}$, el EVOH presenta la ventaja de poder ser transformado con los mismos procesos que otros materiales comunes como las poliolefinas, muestra una alta resistencia química a disolventes, buena resistencia térmica y altísima velocidad de cristalización (Schaper, 1991).

El EVOH suele utilizarse en el envasado de alimentos por sus bajos valores de permeabilidad al oxígeno, pero debido a su sensibilidad a la humedad, en la mayoría de aplicaciones se utilizan estructuras multicapa en las cuales el EVOH se encuentra franqueado entre dos láminas de materiales hidrófobos, como por ejemplo en el material coextruído PP//EVOH//PP. El EVOH lo 
podemos encontrar formando parte tanto de envases flexibles como semirrígidos y rígidos (Wachtel et al., 1985).

\subsection{MATERIALES ACTIVOS PARA EL CONTROL DE LA OXIDACIÓN EN ALIMENTOS}

\subsubsection{Procesos de oxidación en alimentos}

La oxidación es la forma de deterioro de los alimentos más común después de las alteraciones producidas por microorganismos. Las reacciones de oxidación son reacciones en cadena, es decir, una vez iniciadas continúan desarrollándose hasta la oxidación total de las sustancias sensibles. Con la oxidación, aparecen olores y sabores anómalos, se altera el color y la textura del alimento, y desciende el valor nutritivo al perderse algunas vitaminas y ácidos grasos poliinsaturados. Además, los productos formados en la oxidación pueden ocasionalmente llegar a ser nocivos para la salud (Kanner y Rosenthal, 1992; Schaich, 1992).

La industria alimentaria intenta evitar la oxidación de los alimentos mediante diferentes técnicas, muchas de ellas basadas en la reducción de la presencia de oxígeno y de las especies altamente reactivas como son los radicales libres superóxidos, hidroxilo, oxígeno singlete, etc. que se generan por diferentes mecanismos y que se ven implicadas en las reacciones de oxidación de lípidos y otros componentes de los alimentos. El envasado al vacío o en atmósfera modificada, junto con la utilización de envases con las adecuadas características de barrera a gases y radiaciones, o bien la adición directa de antioxidantes al alimento (Becker et al., 2004) son las soluciones comúnmente utilizadas por la industria para el control de los problemas de oxidación de los alimentos. Los antioxidantes desempeñan un papel fundamental garantizando que los alimentos mantengan su sabor y su color y puedan consumirse durante más tiempo. Cuando los antioxidantes se añaden a la grasa o aceite se retrasa el comienzo de las últimas etapas de la 
autooxidación, cuando la ranciedad

-desarrollo de olores y sabores desagradables- se hace evidente. Otra función relevante es proteger ciertas vitaminas y algunos aminoácidos que se destruyen con facilidad debido a la exposición al aire (Nissen et al., 2004; Bozkurt, 2006; Gramza-Michalowska y Regula, 2007).

La mayoría de los productos grasos tienen en su composición sus propios antioxidantes naturales, aunque muchas veces éstos se pierden durante el procesado (refinado de los aceites, por ejemplo), pérdida que debe ser compensada. Por otra parte, la tendencia a aumentar la insaturación de las grasas de la dieta como una forma de prevención de las enfermedades coronarias hace más necesario el uso de antioxidantes, ya que las grasas insaturadas son mucho más sensibles a los fenómenos de oxidación.

Los antioxidantes, en su calidad de aditivos alimentarios, deben estar correctamente etiquetados, debiendo figurar la función del aditivo y su nombre o número $\mathrm{E}$ asignado. Un número $\mathrm{E}$ indica que el aditivo ha sido evaluado por un Comité Científico y que ha sido aceptado por considerarse seguro en todo el territorio de la UE. El número consta de tres dígitos, el primero de los cuales indica el tipo de aditivo -3 para los antioxidantes- y los restantes indican el grupo químico e identifican las sustancias.

Los antioxidantes más comúnmente utilizados en alimentos son el ácido ascórbico (Vitamina C, E300) y sus derivados, como los ascorbatos sódico y cálcico (E301 y E302, respectivamente) y el palmitato de ascorbilo (E304). Son muy solubles en agua, por lo que se utilizan en productos cárnicos, conservas vegetales, zumos, productos de repostería, etc., excepto el palmitato de ascorbilo que es más soluble en grasas y se utiliza en aceites de semillas. Los tocoferoles (E306-309), conocidos como Vitamina E, también son un grupo común de antioxidantes, pero éstos sólo son solubles en las grasas, no en el agua, por lo que se utilizan en alimentos grasos (Lattanzio et al., 1989; Borek-Wajciechowska, 2008; Seppanen et al., 2010) 
También se utilizan en gran medida los antioxidantes sintéticos, como el BHA (Butil-hidroxi-anisol, E-320) y el BHT (Butil-hidroxi-tolueno, E-321) (Pap et al., 1999). El BHA se utiliza para proteger las grasas utilizadas en repostería, fabricación de bizcochos, sopas deshidratadas, etc., y el BHT se utiliza prácticamente siempre mezclado con el BHA, ya que tiene sus mismas aplicaciones. La seguridad de ambos antioxidantes ha sido discutida extensamente, por lo que tienen las mismas limitaciones legales. Ambos compuestos no son mutagénicos, pero son capaces de modificar la acción de ciertos carcinógenos. EI BHT por ejemplo, a dosis relativamente altas, afecta la reproducción en las ratas, especialmente el número de crías por camada y la tasa de crecimiento durante el período de lactancia. En función de estos datos, la OMS ha rebajado recientemente la ingestión diaria admisible.

Debido a las dudas sobre posible toxicidad los antioxidantes sintéticos están siendo cuestionados y hay un creciente interés en la sustitución de estos compuestos por antioxidantes de origen natural.

\subsubsection{Antioxidantes naturales}

Muchos alimentos contienen compuestos antioxidantes en su composición, particularmente los productos vegetales.

El ácido ascórbico es el aditivo y antioxidante más conocido y ampliamente utilizado en la industria alimentaria (Kaur y Kapoor, 2001), si bien se degrada fácilmente al ser expuesto al oxígeno, metales, luz o calor. También, hay referencias científicas que demuestran que, bajo ciertas condiciones, el ácido ascórbico puede tener una actividad pro-oxidante, favoreciendo y acelerando los procesos de oxidación (Niki, 1991; Yen et al., 2002). En esta tesis, este antioxidante se emplea como agente en el desarrollo de un material activo, pero también como antioxidante de referencia para comparar la efectividad de los diferentes agentes y materiales desarrollados.

El ácido ferúlico es el compuesto del grupo de los ácidos hidroxicinámicos más abundante en la pared celular vegetal y presenta elevada capacidad 
antioxidante. Actúa como agente entrecruzante entre la lignina y los polisacáridos, otorgando rigidez en la estructura y resistencia a la degradación por parte de los microorganismos. Por sus propiedades antioxidantes es componente habitual de bloqueadores solares (Scott et al., 1993; Kikuzaki et al., 2002). Tanto el ácido ferúlico como el ácido ascórbico, deben su actividad antioxidante a sus grupos hidroxilo, como se observa en sus estructuras en la Figura 3.

Otro grupo muy interesante de antioxidantes encontrados en plantas son los polifenoles, grupo de sustancias químicas caracterizadas por la presencia de más de un grupo fenol por molécula. Las investigaciones indican que los polifenoles pueden tener además potenciales beneficios para la salud, llegando incluso a reducir el riesgo de contraer enfermedades cardiovasculares y cáncer (Cao et al., 1996; Masuda et al., 2003). Los polifenoles se subdividen, en función de su estructura, en taninos, ligninas y flavonoides, siendo estos últimos compuestos altamente reconocidos por su elevada capacidad antioxidante.

La catequina y la quercitina pertenecen a la familia de los flavonoides, que son pigmentos naturales presentes en los vegetales, semillas, frutas y en bebidas como vino y cerveza, y su actividad antioxidante está ampliamente estudiada (Gordon y Roedig-Penman, 1998; Barclay et al., 1999; Pedrielli et al., 2001; Fukuhara et al., 2002; Martínez-Florez et al., 2002). La catequina es el principal componente de los flavonoides del té verde y la quercitina se encuentra en muchos alimentos como cebolla, manzana, pera y col. Los flavonoides son compuestos fenólicos de bajo peso molecular que comparten un esqueleto común de difenilpiranos (C6-C3-C6), compuesto por dos anillos de fenilos $(A$ y $B$ ) ligados a través de un anillo $C$ de pirano (heterocíclico). 


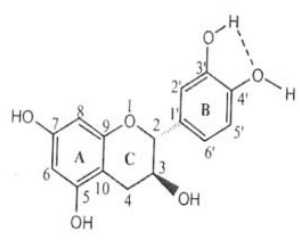

Catequina

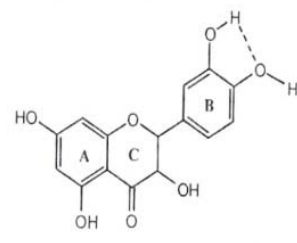

Quercitina

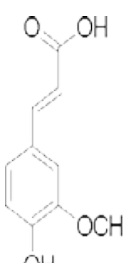

$\mathrm{OH}$

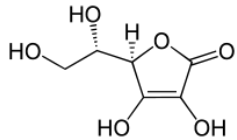

Ácido ascórbico

Figura 3. Detalle de la estructura química de los antioxidantes naturales: catequina, quercitina, ácido ferúlico y ácido ascórbico.

La actividad de los flavonoides como antioxidantes depende de las propiedades redox de sus grupos hidroxifenólicos y de la relación estructural entre las diferentes partes de la estructura química (RiceEvans et al., 1996).

Tres características estructurales son importantes para su función antioxidante: a) La presencia en el anillo B (Figura 3) de la estructura catecol u o-dihidroxibenceno; b) La presencia de un doble enlace en posición 2,3; c) La presencia de grupos hidroxilo en posición 3 y 5 . La quercitina presenta las tres características, mientras que la catequina sólo presenta la primera y la tercera.

Existe consenso en que la actividad antioxidante de los flavonoides resulta de una combinación de sus propiedades quelantes de hierro y secuestradoras de radicales libres $(R L)$ : Otros autores se refieren además a la inhibición de enzimas oxidasas, como la lipoxigenasa, la ciclooxigenasa, etc., evitando la generación de especies reactivas del oxígeno.Por lo menos dos mecanismos están envueltos en la propiedad atrapadora de radicales de los antioxidantes fenólicos (ArOH) (Prior et al., 2005). Uno se basa en la transferencia de un átomo de $\mathrm{H}$, según la reacción (1), y el otro se basa en la transferencia de un electrón seguida de un protón, como se observa en la reacción (2):

$$
\begin{gathered}
\mathrm{G} \cdot+\mathrm{ArOH} \rightarrow \mathrm{GH}+\mathrm{ArO} \cdot \\
\mathrm{G} \cdot+\mathrm{ArOH} \rightarrow \mathrm{G}^{-}+\mathrm{ArOH}^{-} \cdot \rightarrow \mathrm{GH}+\mathrm{Ar}
\end{gathered}
$$


Ambos mecanismos dependen del disolvente del medio y pueden darse en ciertos sistemas químicos y biológicos. A mayor estabilidad del radical formado después de la transferencia mayor será su actividad antioxidante, por lo que teóricamente la quercitina es un antioxidante más activo que la catequina, ya que posee menor potencial de ionización debido a su estructura. Existen discrepancias sobre las reacciones posteriores que tienen lugar en los flavonoides, si bien los estudios coinciden en que pueden llegar a reducir un número elevado de radicales, en algunos trabajos se describen hasta 8 por molécula (Sendra et al., 2007).

\subsubsection{Materiales activos antioxidantes}

Para muchos alimentos sensibles a la oxidación, la eliminación del oxígeno mediante vacío, atmósferas libres de oxígeno o envasado activo con secuestradores de oxígeno, puede no ser una solución satisfactoria ya que se pueden establecer condiciones óptimas para el desarrollo de microorganismos anaerobios patógenos o cambios de pigmentación que conlleven a un rechazo del consumidor. Para este tipo de productos, entre los que se encuentran por ejemplo las carnes frescas, se hace preciso otro tipo de protección. Por otra parte, el control de la oxidación mediante la adición directa de antioxidantes al alimento no siempre es efectivo. Una opción alternativa innovadora propuesta por algunos autores que puede ofrecer buenos resultados es la utilización de envases activos antioxidantes, en los que sustancias antioxidantes se incorporan a la propia composición de material de envase con la intención de que se liberen migrando al alimento de forma controlada con una cinética adecuada, y con la ventaja de que dicha liberación se produciría en la superficie del alimento, que normalmente es la parte más afectada por la oxidación.

Los propios polímeros utilizados en el diseño de envases también son susceptibles a la oxidación, haciéndose más frágiles y menos resistentes, por lo que para su protección se les adiciona antioxidantes en su fabricación para limitar los procesos de degradación que tiene lugar en las operaciones de 
transformación de los polímeros en envases, así como durante su almacenamiento (Mallegol et al., 2001). Existe una gran variedad de compuestos sintéticos que se añaden como antioxidantes en los envases de alimentos, como fosfito, tioésteres y sulfuro, o los compuestos fenólicos BHT e Irganox 1010, que son los más utilizados, y se incorporan a concentraciones entre 0.001-1\% (Dopico-Garcia et al., 2003; Dopico-Garcia et al., 2011b). También se ha desarrollado materiales con algunos antioxidantes sintéticos que tienen la condición de aditivo alimentario con la intención de su liberación al alimento. En 1998, Wessling y colaboradores ya publicaron un trabajo de liberación del antioxidante BHT y tocoferol desde películas de polietileno a simulantes de alimento graso. Torres-Arreola y colaboradores (2007) también han estudiado el retraso de la peroxidación y desnaturalización de proteínas por la incorporación de BHT en polietileno de baja densidad.

Sin embargo, la presencia de estos antioxidantes sintéticos en los alimentos es cuestionada por sus potenciales riesgos y requieren un estricto control legislativo, por lo que existe un gran interés en la sustitución de estas sustancias sintéticas por compuestos antioxidantes naturales (Bruhn, 2000; Dopico-Garcia et al., 2011a). Muchos trabajos se están llevando a cabo en esta línea de investigación para el desarrollo de materiales activos con antioxidantes naturales, como el tocoferol o el extracto de romero (Bentayeb et al., 2007; Jung et al., 2009; Gemili et al., 2010; Nerín, 2010; Gimenez et al., 2011), cuya migración controlada puede significar la incorporación de estas sustancias al alimento, desempeñando de esta forma un papel dual de antioxidante en el envase y en el producto envasado (Figura 4).

Cabe destacar que estos sistemas activos también podrían ejercer actividad antioxidante sin la necesidad de que se encuentren en contacto directo con el alimento, es decir, sin que ocurra la liberación y disolución de los compuestos activos en el alimento. Estos sistemas se comportan como scavengers de radicales libres, como se ha demostrado en varios trabajos (Pezo et al., 2008; López de Dicastillo et al., 2011).

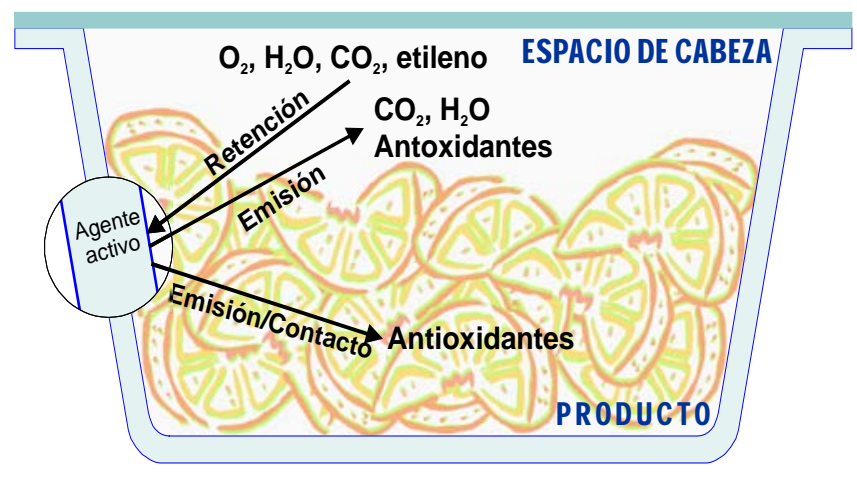


Figura 4. Esquema de un envase activo antioxidante.

Nerín y colaboradores (2006) han probado la eficacia de películas de polipropileno con extracto de romero en la estabilización de carne fresca de ternera, comprobando que tanto la concentración de mioglobina como la conservación de la carne se vieron positivamente favorecidas por la acción antioxidante de estos materiales. De forma análoga, Camo y colaboradores (2008) comprobaron la efectividad de películas activas con extracto de orégano y romero en el envasado de carne de cordero, alcanzando alta efectividad, principalmente los materiales con orégano, que redujeron la oxidación aproximadamente un $60 \%$ respecto al control. La aplicación de estos sistemas activos en la conservación de pescado también se ha estudiado en profundidad. Pereira de Abreu y colaboradores (2010) han estudiado la actividad antioxidante de películas de polietileno de baja densidad, LDPE, con extracto de cáscara de cebada en la conservación de salmón congelado.

Varios trabajos también se han basado en la incorporación de agentes antioxidantes en películas comestibles, como son los desarrollados por Gómez-Estaca y colaboradores (2007), que alcanzaron un retardo en la oxidación de sardinas ahumadas con películas de gelatina con extractos acuosos de orégano y romero, y el desarrollado por Gemili y colaboradores (2010), cuyo objetivo era la liberación controlada de ácido ascórbico y Ltirosina a partir de películas de acetato de celulosa.

Todos estos sistemas activos para el control de la oxidación están basados en polímeros convencionales, estando la mayoría de los desarrollos comerciales 
constituidos por poliolefinas. Solo en fechas recientes se ha empezado a trabajar con biopolímeros y aunque las perspectivas son excelentes aun son muy escasos los resultados.

En esta tesis se ha estudiado el desarrollo de materiales activos antioxidantes, por incorporación de antioxidantes naturales a copolímeros de etileno alcohol vinílico como matriz polimérica. Estos materiales tienen alto atractivo porque, aunque son procedentes del petróleo pueden ser biodegradables y, asimismo, gracias a su naturaleza hidrofílica la liberación de los agentes activos se ve favorecida con la humedad creada por el propio alimento en el envase. Además, presentan la novedad de que los antioxidantes incorporados no son volátiles, por lo que no tendrían un impacto notable sobre las características aromático/sensoriales del alimento.

\subsection{MATERIALES ACTIVOS PARA EL CONTROL DE COMPUESTOS INDESEABLES EN ALIMENTOS}

Desde el momento de su envasado los alimentos inician su degradación hasta el final de su vida útil generando, entre otros, compuestos volátiles tales como algunos aldehídos o cetonas producidos por oxidación lipídica o glicólisis anaeróbica, sulfuros y aminas generados en la degradación proteica, etc., que pueden conferir al alimento olores indeseables, llevando incluso a su rechazo por parte del consumidor. Otros alimentos contienen algún compuesto indeseado, como sería el caso del colesterol en leche y productos lácteos o las aminas biógenas en pescados. La presencia de estos compuestos puede controlarse en muchos casos mediante la incorporación al envase de alguna sustancia absorbente que atrape al compuesto en su estructura (Rooney, 1995; Del Nobile et al., 2002; Suloff et al., 2003; López-Rubio et al., 2004). Materiales porosos o finamente particulados, tales como zeolita, tamiz molecular, arcillas, carbón activo o ciclodextrinas se han propuesto como atrapadores de moléculas indeseables. 
Actualmente existen pocos materiales usados comercialmente para eliminar componentes de olor o sabor o en general compuestos no deseables en los alimentos. El objetivo de estos sistemas activos es mantener la calidad y seguridad de los alimentos envasados a partir de la eliminación de olores extraños y sustancia indeseables, pero, fundamentalmente, sin encubrir algún signo de deterioro del producto envasado, pues se estaría engañando al consumidor.

\subsubsection{Formación de complejos de inclusión con ciclodextrinas}

Las ciclodextrinas son un grupo de moléculas naturales cíclicas constituidas por unidades de glucopiranosa unidas por enlaces $\alpha-(1,4)$. Se obtienen por degradación enzimática del almidón mediante el enzima glucosiltransferasa (CGT amilasa de Bacillus macerans), que produce una reacción intramolecular sin la participación de una molécula de agua. Existen numerosas ciclodextrinas, que se diferencian fundamentalmente en el número de unidades de glucopiranosa, que varía entre 5 y 32 unidades. En la Figura 5 se representan las tres ciclodextrinas más habituales $\alpha, \beta$, y $\mathrm{Y}$-ciclodextrina, con 6, 7 y 8 unidades de glucosa, respectivamente. Presentan una estructura troncocónica hueca; sus principales propiedades son el diámetro de su cavidad y su solubilidad. El diámetro de la cavidad para cada tipo de ciclodextrina implica la complejación de distintas moléculas.
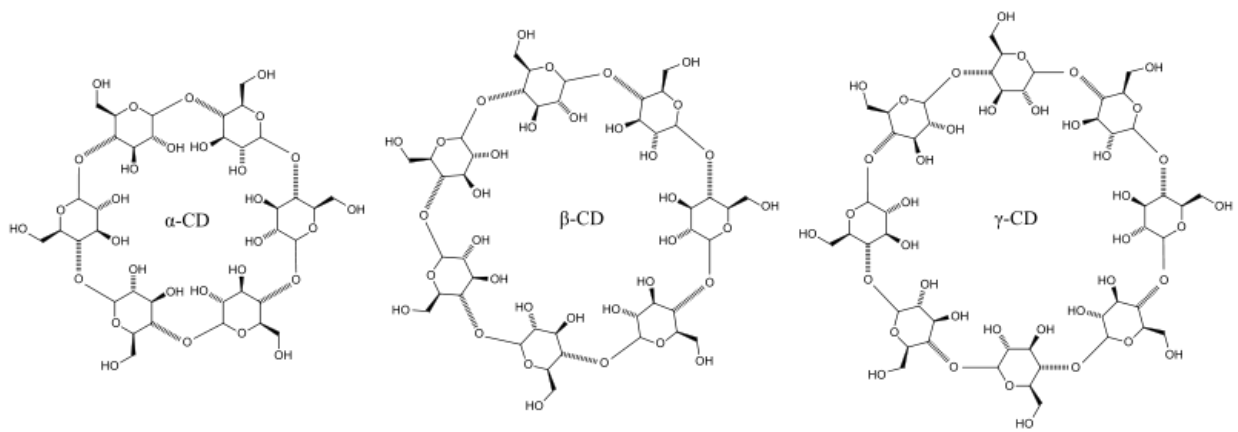


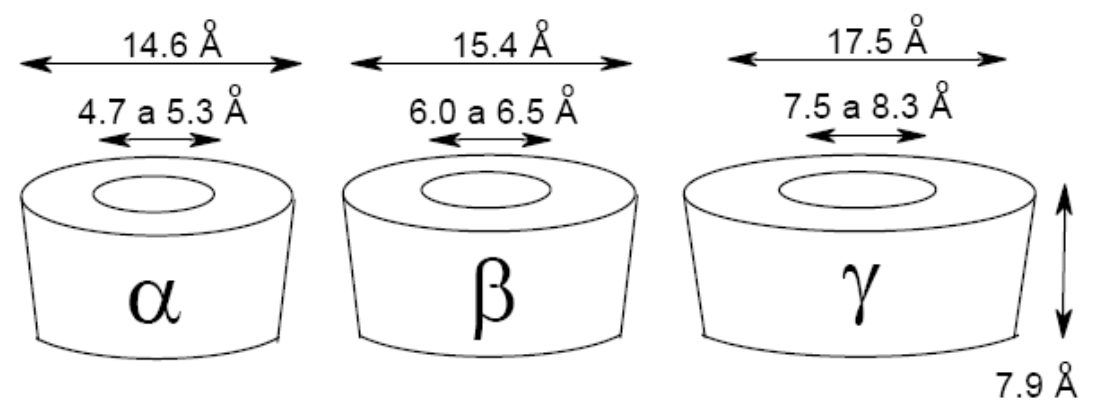

Figura 5. Estructura de los distintos tipos de ciclodextrinas.

Debido a la presencia de los grupos hidroxilo hidrofílicos en los extremos de la cavidad, las ciclodextrinas son solubles en agua y son insolubles en la mayoría de los solventes orgánicos comunes. El interior del cono consiste en tres bandas superpuestas, dos de unidades $\mathrm{C}-\mathrm{H}$ y en medio una de unidades de oxígeno glucosídico. Por lo tanto, los pares electrónicos no compartidos de los puentes de oxígeno hacen que la cavidad interior sea hidrófoba (Szente y Szejtli, 1999; Reineccius et al., 2002; Del Valle, 2004).

La formación de complejos de inclusión está regida por un proceso de reconocimiento molecular, para el cual es necesario que se cumplan dos requisitos: a) Compatibilidad geométrica, en cuanto a tamaño y forma entre el hospedador y el huésped; b) Compatibilidad en la polaridad; a mayor polaridad del huésped, menor capacidad de formar complejos. En el caso de moléculas apolares, como el colesterol, se facilita la formación de complejos. Las fuerzas intermoleculares que hacen posible que se forme el complejo son fuerzas de Coulomb, dipolo-dipolo, Van der Waals, puentes de hidrógeno, etc., que impiden la separación de los componentes. Las moléculas incluidas están normalmente orientadas de modo que se alcance el máximo contacto entre la parte hidrófoba de la molécula huésped y la cavidad de la ciclodextrina apolar (Figura 6). 


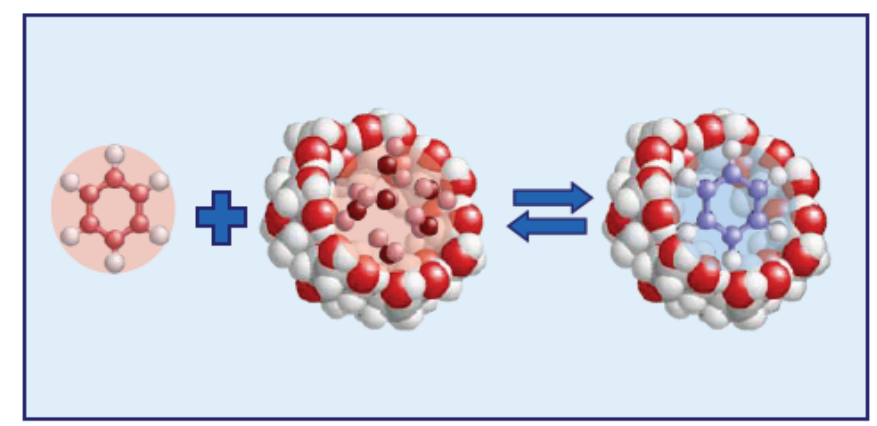

Figura 6. Formación de complejos de inclusión.

Gracias a la capacidad de las ciclodextrinas de formar complejos de inclusión estables, éstas disponen de multitud de aplicaciones en tecnología de alimentos, farmacología, biotecnología, etc., tanto para conseguir una liberación controlada de un compuesto activo previamente encapsulado, o como agente atrapador de sustancias indeseables (Reineccius et al., 2003, 2004).

\subsubsection{Aplicación para la eliminación de colesterol y sustancias indeseables producto de la oxidación lipídica de cacahuetes}

Las ciclodextrinas se han aplicado en la industria alimentaria principalmente actuando como agentes encapsulantes de ingredientes alimentarios, compuestos bioactivos e incluso aromas, para su protección de la oxidación o de la luz, disminuyendo su volatilidad o incluso aumentando la solubilidad de varios compuestos (Reineccius et al., 2002; Szente y Szejtli, 2004). Las ciclodextrinas, principalmente la $\beta$-ciclodextrina, también se utilizan para atrapar y reducir compuestos indeseables que generan sabores y olores desagradables, como el sabor amargo del café o del té (Yu, 1988) o de zumos cítricos (Shaw y Wilson, 1983), aunque en la reducción de colesterol es probablemente una de las principales aplicaciones de la $\beta$-ciclodextrina en el sector alimentario (Comini y Mentink, 1994).

El colesterol (colest-5-en-3- $\beta$-ol) es un lípido esteroide, cuya estructura básica es la del compuesto ciclopentano-perhidrofenantreno, hidrocarburo policíclico 
constituído por cuatro anillos fusionados, que se puede considerar un producto de la saturación del fenantreno asociado a un anillo de ciclopentano. Los esteroides que tienen un grupo $-\mathrm{OH}$ se denominan esteroles, siendo el más conocido de ellos el colesterol. En esta molécula se puede distinguir una cabeza polar, constituida por el grupo hidroxilo, y una cola apolar formada por el carbociclo de núcleos condensados y los sustituyentes alifáticos. Esta estructura le confiere a la molécula de colesterol la característica de ser altamente hidrófoba. Además, su tamaño es compatible con la cavidad de la $\beta$-ciclodextrina. En la bibliografía es posible encontrar complejos colesterol/ $\beta C D$ con ratios desde $1 / 1$ hasta $1 / 3$ (Yamamoto et al., 2005). Algunos autores han alcanzado la reducción de colesterol en leche y otros productos a través de este proceso, describiéndose productos como mantequilla y queso con bajo colesterol, donde no se aprecia diferencia respecto a los productos no tratados (Alonso et al., 2009; Kim et al., 2009; Dias et al., 2010).

La captura del colesterol y demás compuestos es posible gracias a la liberación de entalpía debida a la sustitución de las moléculas de agua, que se encuentran en la cavidad de la ciclodextrina, por moléculas huésped hidrófobas, ocurriendo una asociación apolar-apolar, que disminuye la tensión en la cavidad de la ciclodextrina, resultando en un estado energético de menor energía y más estable.

Las ciclodextrinas también han sido utilizadas para retener o liberar compuestos volátiles como aromas, aldehídos, cetonas, etc. (Suratman et al., 2004; Almenar et al., 2007a; Almenar et al., 2007b). La utilización de ciclodextrinas como agentes activos en polímeros ha sido estudiada por diversos autores, que han inmovilizado ciclodextrinas o derivados en diferentes soportes poliméricos, tanto para la liberación de algún compuesto activo (Almenar et al., 2009), o como membranas para la separación de mezclas de compuestos (Yamasaki et al., 1994; Lue y Peng, 2003; Kusumocahyo et al., 2004; Xiao y Chung, 2007; Touil et al., 2008). La mayoría de estas membranas se prepararon por la técnica de disolución / evaporación 
y se añadieron distintos agentes entrecruzantes para conseguir la inmovilización de estos oligosacáridos en el polímero.

Los trabajos orientados a la aplicación en alimentos son más escasos. Soares y sus colaboradores (2007) desarrollaron por "impresión molecular" ("molecular imprinting") un polímero basado en la matriz polimérica de silica con ciclodextrinas inmovilizadas para la extracción de colesterol. Sidhu y colaboradores (1993) prepararon polímeros de ciclodextrinas con el mismo fin.

En esta tesis se ha estudiado el desarrollo de materiales activos con inclusión de ciclodextrinas en la matriz polimérica para la eliminación de sustancias indeseables como son el colesterol de la leche o los productos de oxidación de los cacahuetes.

\subsection{REFERENCIAS}

Almenar, E., Auras, R., Rubino, M., Harte, B., (2007a). A new technique to prevent the main post harvest diseases in berries during storage: Inclusion complexes betacyclodextrin-hexanal. International Journal of Food Microbiology 118(2), 164-172.

Almenar, E., Auras, R., Wharton, P., Rubino, M., Harte, B., (2007b). Release of acetaldehyde from beta-cyclodextrins inhibits postharvest decay fungi in vitro. Journal of Agricultural and Food Chemistry 55(17), 7205-7212.

Almenar, E., Catala, R., Hernandez-Munoz, P., Gavara, R., (2009). Optimization of an active package for wild strawberries based on the release of 2-nonanone. Lwt-Food Science and Technology 42(2), 587-593.

Alonso, L., Cuesta, P., Fontecha, J., Juarez, M., Gilliland, S.E., (2009). Use of betacyclodextrin to decrease the level of cholesterol in milk fat. Journal of Dairy Science 92(3), 863-869.

Appendini, P., Hotchkiss, J.H., (2002). Review of antimicrobial food packaging. Innovative Food Science \& Emerging Technologies 3, 113-126.

Aucejo, S., (2000). Study and characterization of the humidity effect on the barrier properties of hydrophillic polymeric structures. Ph.D. Dissertation_Univ.Valencia (Spain).

Aucejo, S., Catala, R., Gavara, R., (2000). Interactions between water and EVOH food packaging films. Food Science and Technology International 6(2), 159-164.

Barclay, L.R.C., Edwards, C.E., Vinqvist, M.R., (1999). Media effects on antioxidant activities of phenols and catechols. Journal of the American Chemical Society 121(26), 6226-6231.

Becker, E.M., Nissen, L.R., Skibsted, L.H., (2004). Antioxidant evaluation protocols: Food quality or health effects. European Food Research and Technology 219(6), 561-571. 
Bentayeb, K., Rubio, C., Batlle, R., Nerín, C. (2007). Direct determination of carnosic acid in a new active packaging based on natural extract of rosemary. Analytical and Bioanalytical Chemistry 389, 1989-1996.

Borek-Wajciechowska, R., (2008). Influence of I-ascorbic acid addition on the content of fatty acids in butter during storage. Polish Journal of Food \& Nutritional Sciences. 58(1), 91-94.

Bozkurt, H., (2006). Utilization of natural antioxidants: Green tea extract and Thymbra spicata oil in Turkish dry-fermented sausage. Meat Science 73(3), 442-450.

Brody, A.L., (2001a). What's active about intelligent packaging. Food Technology 55(6), 75-78.

Brody, A.L., Strupinsky, E.R., Kline, L.R., (2001b). Active packaging for food applications. Technomic Publishing Co. Inc. , Lancaster PA, USA.

Brown, W.E., (1992). Plastics in Food Packaging. Properties, design and fabrication., in: Marcel Dekker, I. (Ed.), Nueva York.

Bruhn, C., (2000). Food labelling: Consumer needs., in: Ralph, I.J. (Ed.), Food labelling. Blanchfield Cambridge: Woodhead Publishing Limited.

Camo, J., Beltran, J.A., Roncales, P., (2008). Extension of the display life of lamb with an antioxidant active packaging. Meat Science 80(4), 1086-1091.

Cao, G.H., Sofic, E., Prior, R.L., (1996). Antioxidant capacity of tea and common vegetables. Journal of Agricultural and Food Chemistry 44(11), 3426-3431.

Catalá, R., Gavara, R., ( 2001 ). Nuevos envases. De la protección pasiva a la defensa activa de alimentos envasados. Arbor CLXVIII/661,, 109-127.

CE 2000: Directiva 2000/13/CE del Parlamento Europeo y del Consejo, de 20 de marzo de 2000, relativa a la aproximación de las legislaciones de los Estados miembros en materia de etiquetado, presentación y publicidad de los productos alimenticios. Diario Oficial de las Comunidades Europeas No L109 de 6/5/2000, 2942.

CE 2004: Reglamento(CE) n: 1935/2004 del Parlamento Europeo y del Consejo, de 27 de octubre de 2004, sobre los materiales y objetos destinados a entrar en contacto con alimentos y por el que se derogan las Directivas 80/590/CEE y 89/109/CEE. Diario Oficial de las Comunidades Europeas No L 338 de 13/11/2004 Bruselas, Bélgica, 4.

CE 2009 Reglamento(CE) n: 450/2009 de la Comisión, de 29 de mayo de 2009, sobre los materiales y objetos activos e inteligentes destinados a entrar en contacto con alimentos. Diario Oficial de la Unión Europea No L135 de 30/5/2009, 3-11.

Comini, S., Mentink, L., (1994). Process for refining mixtures resulting from treatment of fatty substances with cyclodextrin and containing complexes of cyclodextrin with fatty acid type lipophilic compounds. Roquette Freres, France, United States.

Del Nobile, M.A., Buonocore, G.G., Fava, P., Piergiovanni, L., (2002). Modeling of hexanal sorption kinetic in an aldehydes scavenger film intended for food packaging applications. Journal of Food Science 67(7), 2687-2691.

Del Valle, E.M.M., (2004). Cyclodextrins and their uses: a review. Process Biochemistry 39(9), 1033-1046. 
Dias, H., Berbicz, F., Pedrochi, F., Baesso, M.L., Matioli, G., (2010). Butter cholesterol removal using different complexation methods with beta-cyclodextrin, and the contribution of photoacoustic spectroscopy to the evaluation of the complex. Food Research International 43(4), 1104-1110.

Dopico-Garcia, M.S., Castro-Lopez, M.M., Lopez-Vilarino, J.M., Gonzalez-Rodriguez, M.V., Valentao, P., Andrade, P.B., Garcia-Garabal, S., Abad, M.J., (2011a). Natural Extracts as Potential Source of Antioxidants to Stabilize Polyolefins. Journal of Applied Polymer Science 119(6), 3553-3559.

Dopico-Garcia, M.S., Cela-Perez, C., Lopez-Vilarino, J.M., Gonzalez-Rodriguez, M.V., Barral-Losada, L.F., (2011b). An Approach to Imprint Irganox 1076: Potential Application to the Specific Migration Test in Olive Oil. Journal of Applied Polymer Science 119(5), 2866-2874.

Dopico-Garcia, M.S., Lopez-Vilarino, J.M., Gonzalez-Rodriguez, M.V., (2003). Determination of antioxidant migration levels from low-density polyethylene films into food simulants. Journal of Chromatography A 1018(1), 53-62.

Dury-Brun, C., Chalier, P., Desobry, S., Voilley, A., (2007). Multiple mass transfers of small volatile molecules through flexible food packaging. Food Reviews International 23(3), 199-255.

Farkas, J.K., (1998). The development of iron-based oxygen absorbing systems used in food packaging and preservation., Ph.D. dissertation. Purdue University, West Lafayette.

Fukuhara, K., Nakanishi, I., Kansui, H., Sugiyama, E., Kimura, M., Shimada, T., Urano, S., Yamaguchi, K., Miyata, N., (2002). Enhanced radical-scavenging activity of a planar catechin analogue. Journal of the American Chemical Society 124(21), 59525953.

Garces Lardies, O., Nerin de la Puerta, C. (2008). Antimicrobial packaging e.g. food applications has coating containing natural extracts of plants with antibacterial / fungicial / antioxidant agents disloved / dispersed in basic formulation comprising resin substrate, solvents and additives. European patent number EP1657181-A1, ARTIBAL SA.

Gavara, R., Catala, R., (2002). Mass transfer in food / plastic packaging systems in Engineering and Food for the 21st Century., in: Welti-Chanes, J., BarbosaCánovas, G., Aguilera, J.M. (Eds.), Food Preservation Technology Series. CRC Press., Washington D.C.

Gemili, S., Yemenicioglu, A., Altinkaya, S.A., (2010). Development of antioxidant food packaging materials with controlled release properties. Journal of Food Engineering 96(3), 325-332.

Gimenez, B., Gomez-Guillen, M.C., Perez-Mateos, M., Montero, P., Marquez-Ruiz, G., (2011). Evaluation of lipid oxidation in horse mackerel patties covered with boragecontaining film during frozen storage. Food Chemistry 124(4), 1393-1403.

Gomez-Estaca, J., Montero, P., Gimenez, B., Gomez-Guillen, M.C., (2007). Effect of functional edible films and high pressure processing on microbial and oxidative spoilage in cold-smoked sardine (Sardina pilchardus). Food Chemistry 105(2), 511520.

Gordon, M.H., Roedig-Penman, A., (1998). Antioxidant activity of quercetin and myricetin in liposomes. Chemistry and Physics of Lipids 97(1), 79-85. 
Gramza-Michalowska, A., Regula, J., (2007). Use of tea extracts (Camelia sinensis) in jelly candies as polyphenols sources in human diet. Asia Pacific Journal of Clinical Nutrition 16, 43-46.

Gutierrez, L., Sanchez, C., Batlle, R., Nerin, C. (2009). New antimicrobial active package for bakery products. Trends in Food Science \& Technology 20, (2), 92-99.

Han, J.H., (2005). Innovations in Food Packaging., in: Series, I. (Ed.), Elsevier Academic Press, Amsterdam.

Hernandez, R.J., Selke, S.E.M., Culter, J.D., (2000). Plastics Packaging - Properties, processing, applications, and regulations., in: Publishers, H. (Ed.), Munich.

Hotchkiss, J.H.C., (2000). Current and future trends in active packaging. Memorias II Congreso Internacional de Envases y Embalajes RISEA-2000 - Hermosillo So., México.

Iwanami, T., Hirai, Y., (1983). Ethylene vinyl alcohol resins for gas-barrier material. Tappi Journal 66(10), 85-90.

Jung, D.C., Lee, S.Y., Yoon, J.H., Hong, K.P., Kang, Y.S., Park, S.R., Park, S.K., Ha, S.D., Kim, G.H., Bae, D.H., (2009). Inhibition of pork and fish oxidation by a novel plastic film coated with horseradish extract. Lwt-Food Science and Technology 42(4), 856-861.

Kanner, J., Rosenthal, I., (1992). An assessment of lipid oxidation in foods - technical report. Pure and Applied Chemistry 64(12), 1959-1964.

Kaur, C., Kapoor, H.C., (2001). Antioxidants in fruits and vegetables - the millennium's health. International Journal of Food Science and Technology 36(7), 703-725.

Kerry, J.P., O'Grady, M.N., Hogan, S.A., (2006). Past, current and potential utilisation of active and intelligent packaging systems for meat and muscle-based products: A review. Meat Science 74(1), 113-130.

Kikuzaki, H., Hisamoto, M., Hirose, K., Akiyama, K., Taniguchi, H., (2002). Antioxidant properties of ferulic acid and its related compounds. Journal of Agricultural and Food Chemistry 50(7), 2161-2168.

Kim, S.Y., Hong, E.K., Ahn, J., Kwak, H.S., (2009). Chemical and sensory properties of cholesterol-reduced processed cheese spread. International Journal of Dairy Technology 62(3), 348-353.

Kusumocahyo, S.P., Kanamori, T., Sumaru, K., Iwatsubo, T., Shinbo, T., (2004). Pervaporation of xylene isomer mixture through cyclodextrins containing polyacrylic acid membranes. Journal of Membrane Science 231(1-2), 127-132.

Labuza, T.P., (1996). An introduction to active packaging for foods. Food Technology 50(4), 68-71.

Lattanzio, V., Linsalata, V., Palmieri, S., Vansumere, C.F., (1989). The beneficial effect of citric and ascorbic acid on the phenolic browning reaction in stored artichoke (Cynara scolymus) heads. Food Chemistry 33(2), 93-106.

Lee, D.S., Yam, K.L., Piergiovanni, L., (2008). Food packaging science and technology., in: Press, C. (Ed.), London. 
Lopez, P., Sanchez, C., Batlle, R., Nerin, C. (2007). Development of flexible antimicrobial films using essential oils as active agents. Journal of Agricultural and Food Chemistry 55, (21), 8814-8824.

López de Dicastillo, A.C., Pezo, D., Nerín, C., López-Carballo, G., Catalá, R., Gavara, R., Hernández-Muñoz, P. Reducing oxidation of foods through antioxidant active packaging based on EVOH and natural flavonoids. (por publicar).

Lopez-Rubio, A., Almenar, E., Hernandez-Munoz, P., Lagaron, J.M., Catala, R., Gavara, R., (2004). Overview of active polymer-based packaging technologies for food applications. Food Reviews International 20(4), 357-387.

Lopez-Rubio, A., Lagaron, J.M., Gimenez, E., Cava, D., Hernandez-Munoz, P., Yamamoto, T., Gavara, R., (2003). Morphological alterations induced by temperature and humidity in ethylene-vinyl alcohol copolymers. Macromolecules 36(25), 9467-9476.

Lopez-Rubio, A., Lagaron, J.M., Hernandez-Munoz, P., Almenar, E., Catala, R., Gavara, R., Pascall, M.A., (2005). Effect of high pressure treatments on the properties of EVOH-based food packaging materials. Innovative Food Science \& Emerging Technologies 6(1), 51-58.

Lue, S.J., Peng, S.H., (2003). Polyurethane (PU) membrane preparation with and without hydroxypropyl-beta-cyclodextrin and their pervaporation characteristics. Journal of Membrane Science 222(1-2), 203-217.

Mallegol, J., Carlsson, D.J., Deschenes, L., (2001). Antioxidant effectiveness of vitamin E in HDPE and tetradecane at 32 degrees C. Polymer Degradation and Stability 73(2), 269-280.

Martínez-Florez, S., González-Gallego, J., Culebras, J.M., Muñon, M.J., (2002). Los flavonoides: propiedades y acciones antioxidantes. Nutr.Hosp. XVII (6), 271-278.

Masuda, T., Inaba, Y., Maekawa, T., Takeda, Y., Yamaguchi, H., Nakamoto, K., Kuninaga, H., Nishizato, S., Nonaka, A., (2003). Simple detection method of powerful antiradical compounds in the raw extract of plants and its application for the identification of antiradical plant constituents. Journal of Agricultural and Food Chemistry 51(7), 1831-1838.

Nerín, C., Tovar, L., Djenane, D., Camo, J., Salafranca, J., Beltran, J.A., Roncales, P., (2006). Stabilization of beef meat by a new active packaging containing natural antioxidants. Journal of Agricultural and Food Chemistry 54(20), 7840-7846.

Niki, E., (1991). Action of ascorbic acid as a scavenger of active and stable oxygen radicals. American Journal of Clinical Nutrition 54, (6), S1119-S1124.

Nissen, L.R., Byrne, D.V., Bertelsen, G., Skibsted, L.H., (2004). The antioxidative activity of plant extracts in cooked pork patties as evaluated by descriptive sensory profiling and chemical analysis. Meat Science 68(3), 485-495.

Oyane, A., Yokoyama, Y., Uchida, M., Ito, A., (2006). The formation of an antibacterial agent-apatite composite coating on a polymer surface using a metastable calcium phosphate solution. Biomaterials 27(17), 3295-3303.

Ozdemir, M., Floros, J.D., (2004). Active food packaging technologies. Critical Reviews in Food Science and Nutrition 44(3), 185-193.

Pap, J., Dimic, E., Ribic, N., Vrbaski, Z., (1999). Effect of additives on quality of frying oil. 
Pedrielli, P., Pedulli, G.F., Skibsted, L.H., (2001). Antioxidant mechanism of flavonoids. Solvent effect on rate constant for chain-breaking reaction of quercetin and epicatechin in autoxidation of methyl linoleate. Journal of Agricultural and Food Chemistry 49(6), 3034-3040.

Pereira de Abreu, D.A.P., Losada, P.P., Maroto, J., Cruz, J.M., (2010). Evaluation of the effectiveness of a new active packaging film containing natural antioxidants (from barley husks) that retard lipid damage in frozen Atlantic salmon (Salmo salar L.). Food Research International 43(5), 1277-1282.

Pezo, D., Salafranca, J., Nerin, C. (2008). Determination of the antioxidant capacity of active food packagings by in situ gas-phase hydroxyl radical generation and highperformance liquid chromatography-fluorescence detection. Journal of Chromatography A 1178, (1-2), 126-133.

Prior, R.L., Wu, X.L., Schaich, K., (2005). Standardized methods for the determination of antioxidant capacity and phenolics in foods and dietary supplements. Journal of Agricultural and Food Chemistry 53(10), 4290-4302.

Reineccius, T.A., Reineccius, G.A., Peppard, T.L., (2002). Encapsulation of flavors using cyclodextrins: Comparison of flavor retention in alpha, beta, and gamma types. Journal of Food Science 67(9), 3271-3279.

Reineccius, T.A., Reineccius, G.A., Peppard, T.L., (2003). Flavor release from cyclodextrin complexes: Comparison of alpha, beta, and gamma types. Journal of Food Science 68(4), 1234-1239.

Reineccius, T.A., Reineccius, G.A., Peppard, T.L., (2004). Utilization of betacyclodextrin for improved flavor retention in thermally processed foods. Journal of Food Science 69(1), C58-C62.

Restuccia, D., Spizzirri, U.G., Parisi, O.I., Cirillo, G., Curcio, M., Iemma, F., Puoci, F., Vinci, G., Picci, N., (2010). New EU regulation aspects and global market of active and intelligent packaging for food industry applications. Food Control 21(11), 14251435.

RiceEvans, C.A., Miller, N.J., Paganga, G., (1996). Structure-antioxidant activity relationships of flavonoids and phenolic acids (vol 20, pg 933, 1996). Free Radical Biology and Medicine 21(3), 417-417.

Rooney, M.L., (1995). Active Food Packaging, in: Profesional, B.A. (Ed.), Chapman \& Hall, Londres (Gran Bretaña).

Scott, B.C., Butler, J., Halliwell, B., Aruoma, O.I., (1993). Evaluation of the antioxidant actions of ferulic acid and catechins. Free Radical Research Communications 19(4), 241-253.

Schaich, K.M., (1992). Metals and lipid oxidation - Contemporary issues. Lipids 27(3), 209-218.

Schaper, E.B., (1991). High barrier plastics packaging and ethylene vinyl alcohol resins (a marriage). in: Henyon, D.K. (Ed.), Food Packaging Technology, pp. 31-36.

Sendra, J.M., Sentandreu, E., Navarro, J.L., (2007). Kinetic model for the antiradical activity of the isolated $p$-catechol group in flavanone type structures using the free stable radical 2,2-diphenyl-1-picrylhydrazyl as the antiradical probe. Journal of Agricultural and Food Chemistry 55(14), 5512-5522. 
Seppanen, C.M., Song, Q.H., Csallany, A.S., (2010). The Antioxidant Functions of Tocopherol and Tocotrienol Homologues in Oils, Fats, and Food Systems. Journal of the American Oil Chemists Society 87(5), 469-481.

Shaw, P.E., Wilson, C.W., (1983). Debittering citrus juices with beta-cyclodextrin polymer. Journal of Food Science 48(2), 646-647.

Sidhu, G.S., Oakenfull, D.G., Rooney, M.L., (1993). Absorbent polymers based on cyclodextrin(s) e.g. modified beta-cyclodextrin inhibit adsorption of cholesterol and bile acid from the intestine, useful for treating hypercholesterolaemia. Commonwealth Sci \& Ind Res Org.

Smith, J.P., Hoshino, J., Abe, Y., (1995). Interactive packaging involving sachet technology. Active food packaging. Blackie Academic and Professional, London, pp. 143-173.

Soares, C.M.F., Zanin, G.M., de Moraes, F.F., dos Santos, O.A.A., de Castro, H.F., (2007). Molecular imprinting of beta-cyclodextrin/cholesterol template into a silica polymer for cholesterol separation. Journal of Inclusion Phenomena and Macrocyclic Chemistry 57, (1-4), 79-82.

Suloff, E.C., Marcy, J.E., Blakistone, B.A., Duncan, S.E., Long, T.E., O'Keefe, S.F., (2003). Sorption behavior of selected aldehyde-scavenging agents in poly(ethylene terephthalate) blends. Journal of Food Science 68(6), 2028-2033.

Suppakul, P., Miltz, J., Sonneveld, K., Bigger, S.W., (2003). Active packaging technologies with an emphasis on antimicrobial packaging and its applications. Journal of Food Science 68(2), 408-420.

Suratman, L.L.I., Jeon, I.J., Schmidt, K.A., (2004). Ability of cyclodextrins to entrap volatile beany flavor compounds in soymilk. Journal of Food Science 69(2), C109C113.

Szente, L., Szejtli, J., (1999). Highly soluble cyclodextrin derivatives: chemistry, properties, and trends in development. Advanced Drug Delivery Reviews 36(1), 1728.

Szente, L., Szejtli, J., (2004). Cyclodextrins as food ingredients. Trends in Food Science \& Technology 15(3-4), 137-142.

Torres-Arreola, W., Soto-Valdez, H., Peralta, E., Cardenas-Lopez, J.L., EzquerraBrauer, J.M., (2007). Effect of a low-density polyethylene film containing butylated hydroxytoluene on lipid oxidation and protein quality of sierra fish (Scomberomorus sierra) muscle during frozen storage. Journal of Agricultural and Food Chemistry 55(15), 6140-6146.

Touil, S., Palmeri, J., Tingry, S., Bouchtalla, S., Deratani, A., (2008). Generalized dualmode modelling of xylene isomer sorption in polyvinylalcohol membranes containing alpha-cyclodextrin. Journal of Membrane Science 317(1-2), 2-13.

Vermeiren, L., Devlieghere, F., van Beest, M., de Kruijf, N., Debevere, J., (1999). Developments in the active packaging of foods. Trends in Food Science \& Technology 10(3), 77-86.

Wachtel, J.A., Tsai, B.C., Farrell, C.J., (1985). Retortable plastic cans keep air out, flavor in. Plastics Engineering 41(2), 41-45. 
Wessling, C., Nielsen, T., Leufven, A., Jagerstad, M., (1998). Mobility of alphatocopherol and BHT in LDPE in contact with fatty food simulants. Food Additives and Contaminants 15(6), 709-715.

Xiao, Y.C., Chung, T.S., (2007). Functionalization of cellulose dialysis membranes for chiral separation using beta-cyclodextrin immobilization. Journal of Membrane Science 290(1-2), 78-85.

Yamamoto, S., Kurihara, H., Mutoh, T., Xing, X.H., Unno, H., (2005). Cholesterol recovery from inclusion complex of beta-cyclodextrin and cholesterol by aeration at elevated temperatures. Biochemical Engineering Journal 22(3), 197-205.

Yamasaki, A., Iwatsubo, T., Masuoka, T., Mizoguchi, K., (1994). Pervaporation of ethanol-water through a poly(vinyl alcohol) cyclodextrin (PVACD) membrane. Journal of Membrane Science 89(1-2), 111-117.

Yen, G.C., Duh, P.D., Tsai, H.L. (2002). Antioxidant and pro-oxidant properties of ascorbic acid and gallic acid. Food Chemistry 79, (3), 307-313

Yu, E.K.C., (1988). Novel decaffeination process using cyclodextrins. Applied Microbiology and Biotechnology 28(6), 546-552. 
2. OBJETIVOS 


\section{OBJETIVOS}

\subsection{OBJETIVO GENERAL}

Desarrollo, caracterización y aplicación de envases activos:

a) para limitar y controlar los procesos de deterioro oxidativo en alimentos, mediante la incorporación de sustancias antioxidantes naturales en materiales plásticos hidrofílicos.

b) para retener o eliminar sustancias indeseables, presentes en el alimento $u$ originadas durante el almacenamiento, a partir de la formación de complejos con ciclodextrinas incorporadas en polímeros hidrofílicos.

\subsection{OBJETIVOS ESPECÍFICOS}

a) Materiales activos para el control de la oxidación:

- Obtener películas de copolímeros de etileno-alcohol vinílico con agentes antioxidantes naturales incorporados mediante técnicas de extrusión y de disolución/evaporación.

- Caracterizar las propiedades físico-químicas de interés de los materiales desarrollados y evaluar el efecto de la incorporación de los antioxidantes en la matriz polimérica y del proceso de obtención de las películas.

- Caracterizar y evaluar la liberación de antioxidantes desde los materiales desarrollados mediante estudios de migración en distintos simulantes alimentarios y comprobar la actividad antioxidante de los antioxidantes liberados.

- Estudiar la aplicación práctica de los materiales para el envasado de alimentos sensibles a la oxidación. 
b) Materiales activos para el control de sustancias indeseables:

- Obtener películas con ciclodextrinas inmovilizadas en copolímeros de etileno alcohol vinílico mediante técnicas de extrusión y de poli (alcohol vinílico) por técnicas de disolución/evaporación.

- Caracterizar las propiedades físico-químicas de las películas desarrolladas de interés para su posible utilización como material de envase.

- Estudiar la aplicación práctica de las películas desarrolladas para la retención de colesterol en leche entera envasada, y de compuestos volátiles desarrollados en la oxidación de cacahuetes. 
3. RESULTADOS Y DISCUSIÓN 


\section{RESULTADOS Y DISCUSIÓN}

En esta memoria y a través de los siete trabajos científicos que la conforman se aborda el desarrollo de dos sistemas activos de interés, cuyos objetivos son el control de los procesos de oxidación en alimentos envasados y la eliminación de sustancias indeseables presentes en el alimento $u$ originadas durante el almacenamiento.

Como materiales base para el desarrollo de estos sistemas activos se proponen los polímeros hidrofílicos $\mathrm{EVOH}$ y $\mathrm{PVOH}$, ampliamente utilizados en el diseño de envases.

Los copolímeros EVOH aportan una elevada protección frente al transporte de gases (oxígeno, dióxido de carbono,...) y compuestos orgánicos, si bien estas propiedades sufren un importante deterioro con la humedad por lo que habitualmente se protegen formando parte de estructuras multicapa en las que el EVOH se encuentra rodeado por materiales hidrofóbicos como las poliolefinas. De este modo, se frena la sorción de agua en el polímero, evitando el consiguiente hinchamiento de la matriz y su plastificación que afecta de forma notable a las propiedades barrera.

Por su parte, el PVOH presenta aún superiores propiedades barrera frente a gases y vapores orgánicos, pero su sensibilidad a la humedad restringe su aplicación en la práctica al envasado de frutos secos o a sistemas donde se aprovecha el carácter hidrosoluble de este polímero.

Con estos materiales se trata de aprovechar, por una parte, su carácter hidrofílico y la presencia de grupos polares en la matriz para conseguir una adecuada interacción entre ellos y los agentes activos incorporados. Por otra parte, se pretende utilizar la conocida plastificación de estos materiales por el agua como mecanismo de iniciación de la actividad en los materiales desarrollados. De esta manera, los envases activos podrían almacenarse en condiciones de baja humedad y en el momento del envasado, con la 
presencia de la humedad del alimento, comenzar su actividad evitando que ésta llegue exhausta al momento del envasado como puede ocurrir en sistemas activos sin mecanismo de iniciación.

Los resultados del trabajo desarrollado se presentan en dos bloques. Los cuatro primeros artículos forman el primer bloque relacionado con el desarrollo y caracterización de materiales activos para el control de la oxidación. El segundo bloque compuesto por tres capítulos expone el desarrollo de materiales activos para el control de sustancias indeseables.

\section{A. Materiales activos para el control de la oxidación}

Para el desarrollo y estudio de materiales activos para el control de la oxidación se han incorporado compuestos con capacidad antioxidante reconocida en el copolímero $\mathrm{EVOH}$, con el objetivo de que su liberación en el alimento permita controlar la presencia de agentes reactivos oxidantes en el alimento evitando así su deterioro. La liberación del agente activo es un proceso complejo consecuencia de los mecanismos de transferencia de masa en polímeros, caracterizados por su extensión, relacionada con el equilibrio de reparto que se alcanza entre material de envase y alimento, y por su cinética, que depende fundamentalmente de la velocidad de difusión del agente antioxidante en la matriz polimérica y la velocidad de difusión o dispersión del mismo en la fase alimento. La extensión y la cinética de la liberación involucran varios factores: concentración inicial del antioxidante en el polímero, su solubilidad en el alimento, coeficiente de difusión en el polímero, coeficiente de partición entre el polímero y el alimento, temperatura y tiempo, factores que es necesario conocer para poder controlar y predecir el comportamiento de los materiales desarrollados en un envasado real. Además de estudiar el efecto de la adición de los agentes en las propiedades funcionales de los materiales, es necesario conocer la cinética de liberación de los agentes, exponiendo las películas a diversos medios simulantes de alimentos, y la capacidad antioxidante de las películas, tanto actuando por 
contacto directo con el alimento, como de forma indirecta, reduciendo la presencia de agentes oxidantes en las inmediaciones del alimento.

En el primer trabajo realizado en esta tesis (Artículo 1: “Improving the antioxidant protection of packaged food by incorporating natural flavonoids into ethylene-vinyl alcohol copolymer (EVOH) films"), se presenta el desarrollo de materiales activos antioxidantes obtenidos por el método convencional de mezclado en fundido y extrusión, basados en EVOH 44 como material polimérico y con dos agentes antioxidantes naturales, la quercitina y la catequina, compuestos polifenólicos con alta capacidad antioxidante reconocida. Además de esta actividad, estos flavonoides presentan otra característica relevante y es su carácter no volátil y un perfil aromático bajo, por lo que su liberación no conlleva un cambio significativo de las características sensoriales del alimento envasado.

Este primer trabajo nos reveló que la adición de estos compuestos no afectaba las propiedades físicas más importantes del polímero para su posterior aplicación como material de envase. Como puede verse en la Figura 1.1 y la Tabla 1.1 de este Artículo 1, no se observaron cambios relevantes en la temperatura de transición vítrea ni en el proceso de fusión, tan solo una ligera fragilización más notable al aumentar la concentración del flavonoide. Sí que se observó que la adición de los agentes produjo un efecto de protección frente a la degradación térmica, retrasando la misma más de $15{ }^{\circ} \mathrm{C}$ como se muestra en la Figura 1.2. No se observaron efectos importantes en la capacidad barrera frente al vapor de agua o el oxígeno (Tabla 1.2), pero sí una ligera coloración amarilla en los materiales con quercitina y ligeramente marrón para los materiales con catequina incorporada.

También se estudió la capacidad de liberación de los flavonoides en diferentes simulantes alimentarios. En los simulantes acuosos (agua y etanol 10\%) se observó una liberación que seguía las leyes de Fick (Figura 1.3) y se procedió a caracterizarla mediante la estimación de los valores de los coeficientes de reparto $(K)$ y de difusión $(D)$ (Figura 1.4). La liberación hacia los simulantes acuosos estuvo limitada por la reducida solubilidad de los 
flavonoides en estos compuestos. En los simulantes grasos se obtuvieron resultados contrarios: una elevada migración hacia etanol 95\% e inferior a los límites de detección en isooctano. En cuanto a la cinética, los valores de $D$ indicaron que se desarrolla de forma más rápida de lo esperable por tratarse de un material como el EVOH. Este resultado se explica por la elevada plastificación de este material cuando se expone a agua o a alcoholes primarios de bajo peso molecular. Además de los estudios de liberación, el estudio de la actividad antioxidante en simulantes alimentarios expuestos a las películas desarrolladas confirmó su posible efecto protector frente a la oxidación.

En este primer artículo quedaron pendientes algunos aspectos de la actividad antioxidante. Por una parte, resolver la controversia observada respecto a su efecto sobre alimentos grasos y, por otra, conocer si los materiales presentan alguna actividad antioxidante sin que se produzca una liberación de los flavonoides de las paredes del envase, aspectos que fueron objeto de estudio en el segundo artículo.

Este Articulo 2 ("Reducing oxidation of foods through antioxidant active packaging base don EVOH and natural flavonoids") tiene como objetivo estudiar la actividad antioxidante de los materiales desarrollados en el artículo anterior cuando no hay contacto directo con el alimento, caso de alimentos sólidos y cuando el alimento es graso. En primer lugar, se estudió la capacidad de reducción de radicales libres presentes en el espacio de cabeza del envase mediante un método que genera y hace fluir radicales hidroxilo por el interior de una bolsa del material analizado. Como puede observarse en los resultados expuestos en la Figura 2.1, los materiales desarrollados mostraron actividad secuestradora de radicales libres sin necesidad de un contacto directo con el alimento que asegure la liberación del agente. Además, los materiales con menor concentración de antioxidante se mostraron más eficaces. 
Para comprobar la actividad en un caso real, se estudió el efecto sobre cacahuetes fritos envasados. La generación de hexanal como consecuencia de los procesos de peroxidación de ácidos grasos insaturados, considerada como parámetro representativo del proceso, se ve significativamente reducida en aquellos envases que incorporan los flavonoides (Figura 2.2).

Para resolver la controversia observada en el primer trabajo sobre la actividad de los materiales en la protección de alimentos grasos por la gran diferencia mostrada con los simulantes grasos utilizados, etanol e isooctano, se planteó el envasado de aceite de girasol. Tal y como se observa en la Figura 2.3, los materiales con antioxidantes presentaron unos valores del índice de peróxidos inferiores a los del blanco. Las muestras con quercetina son las que se mostraron más efectivas, probablemente debida a su mayor compatibilidad con el aceite.

Con estos dos primeros artículos se comprueba que es posible desarrollar materiales activos antioxidantes incluyendo flavonoides en EVOH y mejorar la protección de alimentos sensibles a la oxidación. La quercitina y la catequina son agentes naturales no volátiles con alta capacidad antioxidante y, aunque se encuentran de forma natural en muchos alimentos, hoy no están consideradas como aditivos alimentarios $\mathrm{y}$, por tanto, no podrían comercializarse envases activos en los que estos agentes fueran liberados. Esta condición lleva a plantear un nuevo trabajo.

En ese trabajo (Artículo 3: "Development of new antioxidant active packaging films base don $\mathrm{EVOH}$ and green tea extract') se mantuvo tanto la forma de procesado, mezclado en fundido y extrusión, como el material polimérico base, EVOH 44, sustituyendo los flavonoides anteriores por un extracto completo de té verde, que tiene el estatus de aditivo alimentario, y también elevada capacidad protectora frente a la oxidación ya que está compuesto, entre otros, por varias catequinas.

El proceso de extrusión produjo cambios en la composición del extracto. Como muestra la Figura 3.1, los galatos de las diferentes catequinas se 
reducen, aumentando la concentración de ácido gálico, con una pérdida media del $20 \%$ de la actividad antioxidante inicial. Como se observó en los materiales con catequina y quercitina, la adición del extracto de té verde no modificó de forma relevante las propiedades térmicas, morfológicas y de barrera. Sólo cabe destacar que la incorporación del agente retrasa la degradación térmica del polímero (Figura 3.2) y aumenta ligeramente la cristalinidad del polímero aunque la estructura cristalina es más deficiente (Tabla 3.2). Con estas características, las películas de este material presentan propiedades barrera mejoradas en seco pero en ambientes húmedos empeoran (Tabla 3.3). Se estudió la liberación de antioxidantes a diferentes simulantes alimentarios. De nuevo, el aumento de capacidad antioxidante por la liberación de componentes del extracto fue superior en etanol 95\% (Tabla 3.4 y Figura 3.3). Respecto a los componentes que se liberan, destaca por su elevada concentración y por hacerlo en todos los simulantes ensayados el ácido gálico. En el simulante alcohólico también fue notable la liberación de catequina y de galato de epigalocatequina.

Como se ha comentado, el análisis del contenido real de agentes antioxidantes en los Artículos 1 y 3 reveló que en el proceso de extrusión se perdía aproximadamente entre un 20 y un 35\% (dependiendo del compuesto) del antioxidante incorporado inicialmente. Para tratar de reducir estas pérdidas se propuso el desarrollo de materiales activos antioxidantes a partir de la técnica de disolución-evaporación, también conocida como "casting". Aunque este procedimiento no es una tecnología de aplicación industrial, puede asemejarse a la formación de recubrimientos, muy habitual en el diseño de envases alimentarios. Los resultados de este trabajo se presentan en el Artículo 4 ("Active antioxidant packaging films: Development and effect on lipid stability of brined sardines"). Para este trabajo se seleccionó como material el copolímero EVOH 29 para mejorar la solubilidad y la formación posterior de película. Como agentes antioxidantes se seleccionaron el ácido ascórbico, el ácido ferúlico, la quercitina y el extracto de té verde, cuatro compuestos con diferentes tamaños, solubilidad y características, con la 
intención de estudiar el efecto sobre la liberación y la actividad antioxidante y, en cierta medida, para comparar con los materiales obtenidos en los trabajos anteriores. Como era previsible, el procesado no produjo degradación de los agentes incorporados.

Al igual que con los materiales obtenidos por extrusión, se estudió la cinética de liberación y la actividad antioxidante de dichos materiales en distintos simulantes alimentarios, así como el efecto de la adición de los distintos antioxidantes sobre las características del polímero. En general, pudieron observarse cambios similares a los obtenidos para los materiales extruidos. Ligeros cambios en las propiedades térmicas y morfológicas y una menor degradación térmica, especialmente en los materiales con quercitina y extracto de té. En cuanto a la extensión y cinética de los procesos de liberación, se observó procesos más rápidos para los ácidos orgánicos. No obstante, la utilización del extracto como agente produce un comportamiento similar en todos los simulantes. También se probó la efectividad de estas películas en el envasado de un alimento real, en este caso sardinas saladas, mediante el control de calidad del producto durante el periodo de comercialización. Los resultaron confirmaron que las películas desarrolladas tienen capacidad antioxidante, protegiendo a este alimento frente a la oxidación de grasas, especialmente con las películas con extracto de té verde incorporado.

Para una mejor comprensión del trabajo realizado se resumen y comentan a continuación conjuntamente las propiedades más relevantes de los materiales desarrollados en los cuatro artículos anteriores (Tablas I, II, III y IV).

En la Tabla I de esta sección, se resumen las propiedades térmicas de los materiales objeto de estudio en los cuatro primeros trabajos. Como puede observarse, en todos los materiales desarrollados por extrusión se muestran las mismas tendencias. La adición del agente produce un retraso en la temperatura de degradación del EVOH. También se observa una ligera fragilización inducida por la incorporación de los antioxidantes que es más notable con la concentración de agente. En cuanto a la cristalización del 
$\mathrm{EVOH}$, se muestra en todos los casos una reducción muy leve de la temperatura de fusión que no va acompañada de reducción en la entalpía, que incluso aumenta en los materiales con extracto de té verde.

Tabla I. Propiedades térmicas de los materiales activos desarrollados.

\begin{tabular}{cccccc}
\hline MATERIAL & $\mathrm{T}_{\text {deg }}\left({ }^{\circ} \mathrm{C}\right)$ & $\mathrm{T}_{\mathrm{g}}\left({ }^{\circ} \mathrm{C}\right)$ & $\mathrm{T}_{\mathrm{m}}\left({ }^{\circ} \mathrm{C}\right)$ & $\Delta \mathrm{H}_{\mathrm{m}}(\mathrm{J} / \mathrm{g})$ & $\Delta \mathrm{H}_{\text {corr }}(\mathrm{J} / \mathrm{g})$ \\
\hline \hline Blanco & 414 & $43 \pm 1.3$ & $167 \pm 0.3$ & $-74.8 \pm 1.8$ & $-74.8 \pm 1.8$ \\
Q 1\% & 430 & $42.5 \pm 1.3$ & $165.7 \pm 0.6$ & $-75.2 \pm 1.8$ & $-75.9 \pm 1.8$ \\
Q 5\% & 447 & $50.3 \pm 4.0$ & $164.9 \pm 0.2$ & $-70.4 \pm 1.2$ & $-74.1 \pm 1.2$ \\
Cat. 0.5\% & 395 & $42.7 \pm 1.3$ & $165.4 \pm 0.3$ & $-74.7 \pm 4.2$ & $-75.1 \pm 4.2$ \\
Cat. 2\% & 455 & $44.8 \pm 2.5$ & $165.6 \pm 0.1$ & $-73.0 \pm 1.8$ & $-75.5 \pm 1.8$ \\
GT 5\% & 463 & $49.4 \pm 1.7$ & $163.4 \pm 2.6$ & $-84.3 \pm 5.4$ & $-88.5 \pm 5.4$ \\
\hline Blanco & 414 & $46.7 \pm 2.1$ & $183.6 \pm 1.6$ & $-65.6 \pm 1.7$ & $65.6 \pm 1.7$ \\
AA & 335.6 & $43.8 \pm 0.7$ & $179.3 \pm 2.4$ & $-54.3 \pm 2.0$ & $-57.2 \pm 2.4$ \\
AF & 353.4 & $43.4 \pm 1.1$ & $176.5 \pm 6.0$ & $-60.9 \pm 1.1$ & $-64.1 \pm 1.2$ \\
Q & 420.4 & $46.9 \pm 2.2$ & $177.4 \pm 2.9$ & $-62.7 \pm 0.9$ & $-66.0 \pm 1.0$ \\
GT & 412.4 & $48.6 \pm 2.1$ & $179.5 \pm 1.0$ & $-64.5 \pm 4.2$ & $-67.8 \pm 4.4$ \\
\hline & & & & & \\
\hline
\end{tabular}

Tabla II. Propiedades barreras de los materiales activos antioxidantes.

$$
\begin{array}{cc}
\text { Permeabilidad al Vapor de Agua } & \text { Permeabilidad al Oxígeno } \\
10^{16} \cdot\left(\mathrm{kg} \cdot \mathrm{m} /\left(\mathrm{m}^{2} \text {.s.Pa }\right)\right) & 10^{21} \cdot \mathrm{PO}_{2}\left(\mathrm{~m}^{3} \cdot \mathrm{m} /\left(\mathrm{m}^{2} . \mathrm{s} \cdot \mathrm{Pa}\right)\right.
\end{array}
$$




\begin{tabular}{|c|c|c|c|c|c|}
\hline & RH 50 & RH 75 & RH 100 & RH 50 & RH 90 \\
\hline Blanco & $2.0 \pm 0.1$ & $8.9 \pm 0.6$ & $13.9 \pm 1.0$ & $7.2 \pm 0.2$ & $33.6 \pm 0.9$ \\
\hline Q 1\% & $1.7 \pm 0.1$ & $1.9 \pm 0.1$ & $18.3 \pm 1.3$ & $6.7 \pm 0.4$ & $29.4 \pm 0.6$ \\
\hline Q 5\% & $1.7 \pm 0.4$ & $1.7 \pm 0.1$ & $13.2 \pm 1.6$ & $8.0 \pm 0.2$ & $36.6 \pm 0.3$ \\
\hline Cat. $0.5 \%$ & $1.9 \pm 0.2$ & $1.9 \pm 0.2$ & $16.5 \pm 0.9$ & $7.8 \pm 0.1$ & $40.2 \pm 0.2$ \\
\hline Cat. $2 \%$ & $1.8 \pm 0.2$ & $5.3 \pm 0.6$ & $17.1 \pm 3.0$ & $9.3 \pm 0.4$ & $36.8 \pm 0.4$ \\
\hline GT 5\% & $1.2 \pm 0.1$ & $2.5 \pm 0.1$ & $17.3 \pm 1.0$ & & \\
\hline \multicolumn{6}{|c|}{ "CASTING" } \\
\hline & RH 35 & & RH 90 & RH 35 & RH 90 \\
\hline Blanco & $1.29 \pm 0.02$ & & $27.9 \pm 5.2$ & $17.6 \pm 1.3$ & $91.9 \pm 11.9$ \\
\hline AA & $1.1 \pm 0.2$ & & $80.0 \pm 5.0$ & $6.1 \pm 0.1$ & $242.1 \pm 36.1$ \\
\hline AF & $0.97 \pm 0.12$ & & $25.3 \pm 1.9$ & $13.2 \pm 0.1$ & $135.1 \pm 33.7$ \\
\hline Q & $1.55 \pm 0.03$ & & $17.4 \pm 1.9$ & $9.4 \pm 0.3$ & $85.3 \pm 15.3$ \\
\hline GT & $1.48 \pm 0.06$ & & $20.7 \pm 3.1$ & $8.8 \pm 0.1$ & $80.1 \pm 16.1$ \\
\hline
\end{tabular}

Este cambio puede atribuirse a una estructura cristalina más defectuosa quizás producida por un efecto nucleante de alguno de los compuestos incorporados. Respecto a los materiales desarrollados por "casting", el mayor efecto sobre las propiedades térmicas es consecuencia del tipo de procesado pero comparando con una película control obtenida por "casting", las tendencias son similares a las observadas con los materiales extruidos.

La Tabla II resume los valores de permeabilidad al vapor de agua y oxígeno de los materiales desarrollados con antioxidantes. Los materiales obtenidos por extrusión presentan tendencias similares, con una reducción de la permeabilidad a ambos permeantes a bajas humedades relativas que pueden atribuirse a la elevación de la Tg que conlleva una mayor rigidez de cadena y al aumento de cristalinidad (en el caso del extracto de té verde). A elevada 
humedad ambiental este efecto ya no es notable, e incluso se observa en algunos materiales mayores valores de permeabilidad que la película control.

Los materiales obtenidos por "casting" presentan mayor variabilidad motivada por la presencia de solvente residual del proceso de "casting". No obstante y con la excepción de las películas con ácido ascórbico los valores no difieren en gran medida de la película control.

Finalmente, las Tablas III y IV presentan los resultados de la caracterización de la liberación de los agentes antioxidantes a los diferentes simulantes alimentarios ensayados. Como puede observarse en la Tabla III, la extensión de la liberación difiere entre simulantes y entre agentes. Aumenta en general conforme aumenta el contenido alcohólico del simulante debido a la mayor solubilidad (compatibilidad química) con etanol de la mayoría de los compuestos antioxidantes utilizados. El ácido ascórbico presenta el comportamiento contrario como cabe esperar dada su mayor solubilidad en agua.

Respecto a la velocidad del proceso de liberación, es función de la difusividad de los agentes en la matriz polimérica.

Tabla III. Coeficiente de reparto $(K)$ correspondientes a la liberación de los antioxidantes desde las películas a los simulantes alimentarios.

\begin{tabular}{cccc}
\hline \multicolumn{3}{c}{$K$} \\
\hline \multicolumn{5}{c}{ EXTRUSIÓN } \\
\hline \hline Quercitina & $100 \% \mathrm{H}_{2} \mathrm{O}$ & $10 \% \mathrm{EtOH}$ & $95 \% \mathrm{EtOH}$ \\
Catequina & $5800 \pm 1300$ & $4900 \pm 2000$ & $43 \pm 11$ \\
A.Gálico & $262 \pm 10$ & $212 \pm 28$ & $63 \pm 10$ \\
Cafeína & $10461 \pm 1000$ & $28.7 \pm 12$ & $8.4 \pm 15$ \\
\hline
\end{tabular}




\begin{tabular}{|c|c|c|c|}
\hline \multicolumn{4}{|c|}{ "CASTING" } \\
\hline & $100 \% \mathrm{H}_{2} \mathrm{O}$ & $10 \% \mathrm{EtOH}$ & $95 \% \mathrm{EtOH}$ \\
\hline $\mathrm{AA}$ & $463 \pm 419$ & $127.9 \pm 55$ & $2178 \pm 1064$ \\
\hline AF & $12463 \pm 674$ & $11680 \pm 862$ & $11333 \pm 488$ \\
\hline $\mathrm{Q}$ & $80468 \pm 10173$ & $35931 \pm 4126$ & $76.7 \pm 58$ \\
\hline GT & $908 \pm 155$ & $384 \pm 189$ & $57 \pm 31$ \\
\hline
\end{tabular}

Tabla IV. Coeficiente de difusión $(D)$ de los antioxidantes en las películas desarrolladas expuestas a los simulantes alimentarios.

\begin{tabular}{|c|c|c|c|}
\hline \multicolumn{4}{|c|}{$10^{16} \cdot D$} \\
\hline \multicolumn{4}{|c|}{ EXTRUSIÓN } \\
\hline & 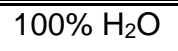 & 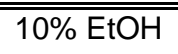 & 95\% EtOH \\
\hline Quercitina & $12 \pm 3$ & $11 \pm 2$ & $60 \pm 10$ \\
\hline Catequina & $8 \pm 3$ & $13 \pm 2$ & $60 \pm 15$ \\
\hline A.Gálico & 2.6 & 12 & 130 \\
\hline \multicolumn{4}{|c|}{ "CASTING" } \\
\hline & 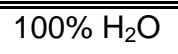 & 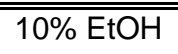 & 95\% EtOH \\
\hline $\mathrm{AF}$ & 500 & 300 & 800 \\
\hline Quercitina & 30 & 30 & 40 \\
\hline GT & 40 & 30 & 50 \\
\hline
\end{tabular}


La Tabla IV demuestra que, en general, la velocidad de difusión en los materiales desarrollados por extrusión aumenta en etanol, tendencia que se atribuye a una mayor plastificación de este polímero por parte del etanol que por el agua.

En el caso del ácido gálico, se observa unos valores menores de $D$ cuando la película está expuesta al agua que para los dos flavonoides, a pesar de su menor tamaño molecular. Esta mayor lentitud puede deberse a la mayor cristalinidad inducida en la muestra de té verde y que supone un aumento de la tortuosidad del camino difusivo del agente en la matriz polimérica. Conforme aumenta el alcohol presente en el simulante, va aumentando la difusividad del ácido gálico. Pudiera ser que en presencia de alcohol se produzca una reducción del impedimiento impuesto al transporte por los cristales en las zonas amorfas próximas, aumentando la flexibilidad de cadena y por tanto la difusividad de los agentes.

En las películas obtenidas por "casting" se obtuvieron valores más homogéneos para los diferentes simulantes. Esta diferencia respecto a los resultados obtenidos por extrusión se debe a la presencia en la matriz de residuos de la mezcla hidroalcohólica de la disolución formadora de película que resulta en películas parcialmente plastificadas y con menor contenido cristalino.

\section{B. Materiales activos para el control de sustancias indeseables}

La segunda parte de esta tesis se centra en el desarrollo y estudio de materiales activos con capacidad para retener o eliminar sustancias indeseables, presentes en el alimento $u$ originadas durante el almacenamiento, a partir de la formación de complejos con ciclodextrinas incorporadas en polímeros hidrofílicos.

El primer trabajo realizado (Artículo 5: "Immobilization of $\beta$-ciclodextrin in ethylene-vinyl alcohol copolymer for active food packaging applications") se centró en el desarrollo de películas activas mediante la incorporación ßle - 
ciclodextrinas, $\beta C D$, en el ṕporo $E V O H ~ 44$, a partir de la técnica de mezclado en fundido durante la extrusión.

Las ciclodextrinas se incorporaron a dos concentraciones, 20 y 30\%, y para mejorar la dispersión del agente en el polímero se utilizó glicerol. El resultado fue una película transparente y flexible, aunque se observaba la presencia de sólidos debido a acumulaciones deßCD $\mathrm{t}$ al y como mostraron las imágenes de SEM.

Los ensayos de inmovilización mostraron que una parte de las $\beta C D$ se liberan cuando el material se sumerge en agua, que principalmente afecta a las $\beta C D$ deficientemente dispersas. Los ensayos para determinar los valores de permeabilidad demostraron que se reducen de forma notable las propiedades barrera (Figuras 5.4-5.7). De gran interés fueron los resultados obtenidos en los estudios de la capacidad de estos materiales para retener compuestos orgánicos, relacionando la polaridad de éstos con la afinidad de los materiales para su captura. Las Figuras 5.8 y 5.9 muestran que las $\beta C D$ y los materiales desarrollados que las incorporan presentan una adsorción preferencial por compuestos apolares, tales como algunos terpenos o hexanal.

Esta característica condujo a plantear el sexto trabajo relacionado con la utilización de las películas desarrolladas en la retención de compuestos no deseados en alimento real (Artículo 6: "Food applications of active packaging $\mathrm{EVOH}$ films containing cyclodextrins for the preferential scavenging of undesirable compounds").

En el sexto artículo se llevó a cabo la aplicación práctica de estos materiales para el envasado de alimentos reales, estudiando la actividad secuestradora de estas películas de sustancias indeseables, como son el colesterol de la leche y los compuestos resultantes de la oxidación de cacahuetes. Las Tablas 6.2 y 6.3 muestran que las películas desarrolladas con estos materiales son efectivas en la retención de colesterol en leche entera, aunque sólo un 25\% de las $\beta C D$ están involucradas en este proceso. Las dificultades de las $\beta C D$ y del colesterol para difundir a través de la matriz de polímero pueden ser 
responsables de esta baja eficiencia. En otro ensayo se utilizaron las películas para reducir la presencia de compuestos volátiles generados en los procesos de oxidación de ácidos grasos insaturados. Los resultados demuestran que las $\beta C D$ son activas en la retención de los aldehídos acumulados en el interior de un envase de cacahuetes. En este ensayo sí que se observó que la práctica totalidad de laßCD estuvieron involucradas en la formáride complejos de inclusión.

Las películas anteriores, aunque transparentes, presentaron discontinuidades por la presencia de aglomerados de $\beta C D$. El objetivo del séptimo y último trabajo de esta tesis (Artículo 7: "Development of active polyvinyl alcohol/ $\beta$ cyclodextrin composites to scavenge undesirable food components") fue la obtención de un material más homogéneo, sin discontinuidades, con el agente bien disperso para alcanzar un mayor secuestro de colesterol. Para ello, se consideró conveniente desarrollar las películas por el método de disoluciónevaporación y así partir con los dos componentes disueltos. Se seleccionó el poli(alcohol vinílico), PVOH, como matriz polimérica, por ser soluble en agua y por que debido a su mayor carácter polar, probablemente tendría mejor afinidad con el exterior de las ciclodextrinas y, a su vez, menor interacción con la cavidad de éstas, permitiendo una mayor captura de colesterol. Para vencer el principal inconveniente de este material que es su elevada solubilidad en agua, fue necesario realizar un entrecruzado químico del polímero con un dialdehído, el glioxal, y optimizar el procedimiento para conseguir no solo evitar la disolución del polímero sino también conseguir una inmovilización adecuada de las $\beta C D$.

Al igual que en los desarrollos anteriores, se procedió a la caracterización funcional de las películas desarrolladas. Como era de esperar, el entrecruzamiento químico conllevó una fragilización del material, retrasándose la temperatura de transición vítrea en más de $15{ }^{\circ} \mathrm{C}$ y una reducción importante de la cristalinidad del polímero. En cuanto a las propiedades barrera, los resultados para la transmisión de vapor de agua fueron dependientes del procedimiento utilizado en el entrecruzamiento. Los valores 
inferiores de permeabilidad se obtuvieron en las dos películas obtenidas en un único proceso de "casting". La presencia en la matriz de un compuesto con menor afinidad por el agua que el propio polímero reduce la solubilidad del composite y con ello la permeabilidad al agua. No se observa el mismo efecto en los valores de permeabilidad al oxígeno, que siempre resultan mayores que la película de $\mathrm{PVOH}$ entrecruzado. Este comportamiento puede atribuirse a la presencia de las ciclodextrinas y su cavidad interior que puede utilizar el oxígeno para su transporte.

Finalmente, se determinó la capacidad secuestradora de colesterol de estos materiales sumergidos en muestras de leche entera. Los resultados mostraron que tras dos días de exposición se había retenido en torno a un 6\% del colesterol inicial en todas las películas desarrolladas. Dos muestras aumentaron la retención hasta casi triplicar este valor al cabo de una semana de almacenamiento en el caso de la muestra obtenida por el doble proceso de "casting". Esta muestra es la que presentó los mayores valores de hinchamiento (Tabla 7.1), y por el procedimiento cabe esperar que la película no sea isótropa, habiendo mayor concentración de ciclodextrinas en una de las caras de la película. Aún así, las películas de PVOH con ciclodextrinas, a pesar de contener una mayor concentración de agente resultaron menos efectivas que las desarrolladas con EVOH.

A continuación se presentan los 7 artículos científicos que conforman la memoria de esta tesis doctoral. 


\subsection{DESARROLLO DE MATERIALES PARA EL CONTROL DE LA OXIDACIÓN EN ALIMENTOS}

Artículo 1: Improving the antioxidant protection of packaged food by incorporating natural flavonoids into ethylene-vinyl alcohol copolymer (EVOH) films.

Artículo 2: Reduction oxidation of foods through antioxidant active packaging based on $\mathrm{EVOH}$ and natural flavonoids.

Artículo 3: Development of new antioxidant active packaging films based on EVOH and green tea extract.

Artículo 4: Active antioxidant packaging films: development and effect on lipid stability of brined sardines. 
Artículo 1

IMPROVING THE ANTIOXIDANT PROTECTION OF PACKAGED FOOD BY INCORPORATING NATURAL FLAVONOIDS INTO ETHYLENE-VINYL ALCOHOL COPOLYMER (EVOH) FILMS

Carol López-de-Dicastillo, José M. Alonso, Ramón Catalá, Rafael Gavara and Pilar Hernández-Muñoz

Journal of Agricultural and Food Chemistry 2010, 58, 10958-10964 


\section{ABSTRACT}

Ethylene vinyl alcohol copolymer (EVOH) films containing catechin or quercetin as antioxidant agents were successfully produced by extrusion. The addition of these bioactive compounds did not modify greatly their water and oxygen permeability, $T_{g}$ or crystallinity but improved their thermal resistance. Exposure of the films to different food simulants showed that both compounds were released, although the extent and kinetics of release were dependent on the type of food. In aqueous and alcoholic food simulants their release was greater in the case of the catechin-containing samples. Exposure of the films to isooctane and ethanol 95\% (fatty food simulants) provided controversial results; no release was observed in isooctane whereas both bioactive compounds were extracted by ethanol due to their high solubility in alcohol and the plasticizing effect of ethanol on the polymer. Packaging applications of these films can improve food stability and provide a method for adding such bioactive compounds.

Keywords: flavonoids, active packaging, antioxidant, release, EVOH 


\section{INTRODUCTION}

Oxidation processes are involved in most deterioration mechanisms present in nature, including both food products and food packages, especially polymeric packages. To protect the polymer during package manufacture and use, most polyolefins contain mixtures of a primary antioxidant which offers long-term protection to the film and a secondary antioxidant which protects the polymer during package manufacture (Caner and Harte, 2005; Crosby, 1981; PerezLamela et al., 1998). Most of the common antioxidants are phenolic compounds, secondary arylamines, organophosphites and thioesters of synthetic origin that are approved by the national and international regulations for plastics in contact with foods. Nevertheless, migration of these additives and their degradation products into food during storage may change the sensory properties of the product they contain or even lead to toxicity upon consumption. For these reasons, several research studies have focused in the development of alternative polymer formulas with antioxidants which are considered food additives, such as BHT, BHA, etc (Bruggemann et al., 2004; Dopico-Garcia et al., 2007; Lu, 1984). However, the presence of these synthetic antioxidants in food is questioned, owing to the potential risks, and strict statutory controls are required. The alternative that is being studied widely is the use of natural antioxidants, particularly tocopherol, plant extracts and essential oils from herbs such as rosemary, oregano, thyme, etc (Moore et al., 2003; Tovar et al., 2005; Wessling et al., 1999).

Many phenolic compounds are commonly found in plants and have been reported to possess multiple biological effects, including antioxidant activity (Balasundram et al., 2006). The principal antioxidant activity of these compounds is mainly as radical scavengers. However, many of the constituents of plant essential oils are volatile and difficult to use in conventional packaging manufacturing processes (extrusion, injection). Some initial studies have proved that natural polyphenolic compounds such as catechin or epicatechin can replace synthetic antioxidants in packaging protection (López-Vilariño et al., 2006). 
To reduce oxidation in sensitive food products, the addition of antioxidants or the design of a suitable packaging technology are the two most common alternatives. Vacuum or modified atmosphere packaging combined with high barrier packaging materials can limit the presence of oxygen, although it is not always completely and effectively eliminated because of a residual presence at the time of packing or because it permeates in from the exterior through the package wall. Moreover, some food products such as fresh red meat cannot be packaged without oxygen. Recently, other strategies are being considered including the use of active antioxidant packages (Granda-Restrepo et al., 2009; Moore et al., 2003; Nerín et al., 2007; Nerín et al., 2006; Peltzer et al., 2009).

EU regulations 1935/2004/EC and 450/2009/EC consider active materials "materials and articles that are intended to extend the shelf-life or to maintain or improve the condition of packaged food", by the on purpose incorporation of components that are released or that absorb substances into or from the packaged food or the environment surrounding the food (Ercolini et al., 2010; Gutierrez et al., 2009; Lopez-Rubio et al., 2004).

Highly reactive species such as free radicals, superoxide, hydroxyl and singlet oxygen are generated in food or in the surrounding atmosphere by different mechanisms and are involved in oxidation reactions in lipids and other food components, contributing to their deterioration. Active packaging systems that absorb these reactive species can be a good choice for many products and constitute one of the potential uses of active packaging. Granda-Restrepo et al. developed polyethylene films with alpha-tocopherol and measured the antioxidant release into milk powder (Granda-Restrepo et al., 2009). Peltzer et al. added carvacrol to polypropylene and measured its migration into water and oil (Peltzer et al., 2009). To reduce the partial loss of volatile antioxidants during conventional packaging manufacturing processes, Nerín et al. developed a polymeric coating with essential oils to protect meat from oxidation (Nerín et al., 2007; Nerín et al., 2006). Nevertheless, volatile agents 
are still released into the atmosphere during storage, reducing the effectiveness of the active materials.

In this work, active antioxidant materials for the packaging of oxygen-sensitive foods, based on an ethylene-vinyl alcohol copolymer (EVOH) and two natural flavonoids, quercetin and catechin, were developed by conventional extrusion. $\mathrm{EVOH}$ is a common packaging material which is known for its excellent oxygen barrier properties and its highly hydrophilic nature (Aucejo et al., 2000; Aucejo et al., 1999; Lopez-Rubio et al., 2003). The main use of this material is to strictly reduce the entrance of oxygen in the package, and in this application the EVOH layer should be sandwiched between polyolefin layers to protect it from the humidity of the environment and of the food. Recently, new data showed the severe effect of humidity on the mass transport of organic compounds, increasing molecular diffusivity several orders of magnitude (Lopez-Carballo et al., 2005). This characteristic is highly profitable since the increment of humidity in the presence of food triggers the agent release and subsequently the antioxidant activity (Lopez-Carballo et al., 2005). The stability of the active materials is guaranteed by dry storage, since the exchange of agents and oxygen is highly restricted.

Quercetin and catechin are phenolic compounds which are commonly found in both edible and nonedible plants. They have been reported to have multiple biological effects, including high antioxidant activity (Boots et al., 2008; Pedrielli et al., 2001). The antioxidant activity of phenolic compounds is due to their ability to scavenge free radicals, donate hydrogen atoms or electrons or chelate metal cations as a result of their chemical structure (Leopoldini et al., 2006; Martínez-Florez et al., 2002; Nakanishi et al., 2002; Sendra et al., 2007). Besides their antioxidant character, these two flavonoids were selected because a) they are non-volatile, reducing the loss of the agent during packaging manufacturing that occurs with other compounds such as BHT or carvacrol, b) they could protect the polymer during processing and furthermore, c) because their release into food increases the product's 
bioactive compound content instead of resulting in a toxicological risk, as occurs with synthetic antioxidants.

The resulting materials were characterized to analyze the effect of the addition of quercetin and catechin on $\mathrm{EVOH}$ functional properties and their antioxidant activity in food was determined by monitoring the agents' release into different food simulants and by analyzing the scavenging capacity of radical oxidizing compounds.

\section{MATERIALS AND METHODS}

\subsection{Chemicals and Reagents}

An ethylene vinyl alcohol copolymer with a $44 \%$ ethylene molar content (EVOH) was obtained from The Nippon Synthetic Chemical Company, (Osaka, Japan). Reagent-grade absolute ethanol, quercetin dihydrate and 2,2diphenyl-1-picrylhydrazyl $95 \%$ free radical were purchased from Sigma (Madrid) and (+) catechin hydrate was purchased from Fluka (Barcelona). Water was obtained from a Milli-Q Plus purification system (Millipore, Molsheim, France).

\subsection{Film Preparation}

$\mathrm{EVOH}$ films containing quercetin and catechin at two different concentrations were obtained by flat extrusion. The antioxidants were incorporated at $1 \%$ and $5 \%$ of quercetin and $0.5 \%$ and $2 \%$ of catechin into hydrophilic EVOH and the antioxidant-EVOH mixture was extruded on a Brabender DSE 20/40 corotating twin screw extruder (Plastograph, Dusseldorf, Germany) at $200{ }^{\circ} \mathrm{C}$ at a screw speed of $100 \mathrm{rpm}$. The resulting films were approximately 40-50 micron thick, although the thickness of every sample was individually measured before tests using a digital Mitutoyo micrometer (Metrotec, San Sebastian, Spain).

The film samples obtained in this way were vacuum packaged in aluminum/LDPE bags and stored at room temperature until the moment of 
analysis. Their thermal properties, oxygen and water vapor transport properties and optical properties were studied.

Flavonoid concentration in the films was determined by extraction in ethanol at $60{ }^{\circ} \mathrm{C}$ during 2 hours. The concentration was then determined by UV-Vis spectroscopy and the retained antioxidant activity by the DPPH. method.

\subsection{Thermal Analysis}

Thermogravimetric analyses were carried out using a Mettler Toledo TGA/SDTA/851 thermal analyzer (Columbus $\mathrm{OH}$, USA). The samples were heated from room temperature to $900{ }^{\circ} \mathrm{C}$ under a nitrogen atmosphere in order to determine any evaporation of volatile compounds, as well as the degradation temperatures of the flavonoid-containing materials.

The thermal properties of the samples were also determined with a DSC Model Q2000 from TA Instruments (New Castle, DE, EEUU). Thermograms from $-50^{\circ} \mathrm{C}$ to $250{ }^{\circ} \mathrm{C}$ with $10^{\circ} \mathrm{C} / \mathrm{min}$ heating and cooling were obtained. The glass transition $\left(\mathrm{T}_{\mathrm{g}}\right)$ and melting point $(\mathrm{Tm})$ temperatures and the enthalpy $(\Delta \mathrm{Hm})$ were calculated. Considering the polymer percentage of each sample, a corrected enthalpy $\left(\Delta \mathrm{Hm}_{\mathrm{cor}}\right)$ value was also estimated.

\subsection{Barrier Properties}

\subsubsection{Water vapor permeability}

WVP tests were carried out at 50\%, 75\% and $100 \% \mathrm{RH}$ and $23{ }^{\circ} \mathrm{C}$ using permeability cups (Elcometer, Manchester, England) in accordance with ISO 2528 (ISO 2528:1995, 1995). The aluminum cups were filled with $7 \mathrm{~g}$ of silica gel and sealed with vacuum silicon grease (Sigma, Barcelona, Spain) and the film to be tested. The film was fixed in place with a flat Viton ring, an aluminum ring and three press-screws. To assure the necessary relative humidity, the cups were then stored in desiccators containing salt solutions: magnesium nitrate $\mathrm{Mg}\left(\mathrm{NO}_{3}\right)_{2} \cdot 6 \mathrm{H}_{2} \mathrm{O}$, sodium chloride $\mathrm{NaCl}$ and water for $50 \%, 75 \%$ and $100 \% \mathrm{RH}$, respectively. The cups were weighed daily, and the plot of the weight increment vs. time provided the water vapor transmission rate. These 
values were then divided by the water pressure gradient and multiplied by the sample thickness to obtain the water vapor permeability value.

\subsubsection{Oxygen permeability}

The oxygen permeation rates of the materials were determined at $50 \%$ and $90 \% \mathrm{RH}$ and $23^{\circ} \mathrm{C}$ using a OXTRAN Model 2/21 ML Mocon (Lippke, Neuwied, Germany). The film samples were previously conditioned at the $\mathrm{RH}$ of the experiment in the desiccators described above. After conditioning the samples in the OXTRAN cells for 6 hours, the transmission values were determined every 45 min until constant.

\subsection{Optical Properties}

The film color was determined with a Konica Minolta CM-35000d spectrophotometer set to D65 illuminant $/ 10^{\circ}$ observer. The film specimens were placed on the surface of a standard white plate and the CIELAB color space was used to determine the parameters, $L^{*}, a^{*}$ and $b^{*}$. The color was also expressed using the polar coordinates $L^{*} C^{*} H^{*}$, where $L^{*}$ is the same as previously, $\mathrm{C}^{*}$ is the chroma or saturation index and $\mathrm{H}^{*}$ is the angle. Eight measurements were taken of each sample and three samples of each film were measured. All the samples were selected with a thickness of $40 \mu \mathrm{m}$ to reduce the effect of thickness on color measurements.

\subsection{Release studies}

A study of the release of the active compounds from the films was carried out by determining the specific migration from the polymer into the different food simulants specified in European law: water was used as an aqueous food simulant, ethanol $10 \%$ as an alcoholic food simulant and ethanol $95 \%$ and isooctane as fatty food simulants. Migration studies were conducted at $37^{\circ} \mathrm{C}$, in accordance with EU regulations (UNE-EN 1186-3) (Dopico-Garcia et al., 2005). Double sided, total immersion migration tests were performed as follows: a $24 \mathrm{~cm}^{2}$ piece of each plastic sample and $90 \mathrm{~mL}$ of the simulant (area-to-volume ratio around $6 \mathrm{dm}^{2} / \mathrm{L}$ ) were placed in a glass vial covered with 
aluminum foil to protect the content from light Simulants were deoxygenated by bubbling nitrogen and a final nitrogen flush was done before closing the cells to reduce the oxygen percentage at the cell headspace. Flavonoid solutions in water and alcohol using this procedure were stable for one month. Periodically, three vials were opened and the concentration of the antioxidant in the simulants was analyzed by UV-spectroscopy. Using an absorbance/concentration $(\mathrm{g} / \mathrm{mL})$ calibration curve, the results can be expressed as the concentration of quercetin or catechin released into the simulants.

At the same time, the antioxidant activity provided by the films was evaluated through measuring the radical scavenging ability of the food simulants, using the method of Okada and Okada with a slight modification (Okada and Okada, 1998). The bleaching rate of a stable free radical, 2,2-diphenyl-1-picrylhydrazyl (DPPH.), was monitored at a characteristic wavelength in the presence of the sample. In its radical form DPPH. absorbs at $517 \mathrm{~nm}$, but upon reduction by an antioxidant or a radical compound its absorption decreases. The percentage inhibition values were calculated using equation 1 :

Using a calibrated curve of ascorbic acid concentration vs I (\%), the results can be expressed easily as the equivalent ascorbic acid concentration. The antioxidant activity of the two flavonoids (as received) was determined by this method. $0.79 \pm 0.03 \mathrm{~g}$ quercetin or $0.89 \pm 0.05$ of catechin were equivalent to $1 \mathrm{~g}$ of ascorbic acid.

\subsection{Statistical analysis}

One-way analyses of variance were carried out. The SPSS ${ }^{\circledR}$ computer program (SPSS Inc., Chicago, IL, USA) was used. Differences in pairs of mean values were evaluated by the Tukey-b test for a confidence interval of $95 \%$. Data are represented as mean \pm standard deviation. 


\section{RESULTS AND DISCUSSION}

In this work, EVOH films containing catechin or quercetin as antioxidant agents were successfully produced by extrusion. The analysis of the ethanol extract of the diverse samples by UV-Vis spectroscopy revealed that the final content of quercetin into Q1\% and Q5\% films was $75.6 \pm 1 \%$ and $80.1 \pm 1.0 \%$ respect to nominal content, respectively. Similar analysis for Cat $0.5 \%$ and Cat $2 \%$ films showed that the final catechin content was $66.8 \pm 1.0 \%$ and $67.1 \pm$ $1.0 \%$, respectively. The analysis of the antioxidant activity by the DPPH. method provided similar results: $71.5 \pm 2 \%$ for Q1\%, $79.5 \pm 1 \%$ for Q5\%, 69.2 $\pm 1 \%$ for Cat $0.5 \%$ and $69.8 \pm 1 \%$ for Cat $2 \%$, with respect to nominal antioxidant activity. Besides these tests, the extract was analyzed by HPLC with DAD (data not shown). Although some minor peaks were present in the spectra, the content of catechin and quercetin measured was in good coincidence with the values obtained by UV-Vis spectroscopy and by the DPPH. test.

\subsection{Thermal characterization}

The films containing the antioxidants were first characterized by DSC to check for effects on the polymer morphology caused by the addition of the flavonoids. Figure 1.1 presents representative first-heating thermograms of the materials developed and Table 1.1 shows the main information obtained from the thermogram analysis. During the first heating, all the samples presented the same features: glass transition at temperatures of ca. $45^{\circ} \mathrm{C}$, a melting endotherm starting at $\sim 120^{\circ} \mathrm{C}$ and with a minimum value at around $165^{\circ} \mathrm{C}$, and temperatures in agreement with the values reported in the literature for pure EVOH (Aucejo et al., 1999; Zhang et al., 1999). Between the glass transition temperature and the melting temperature, all the samples presented a small endotherm at temperatures of ca. $88^{\circ} \mathrm{C}$. 

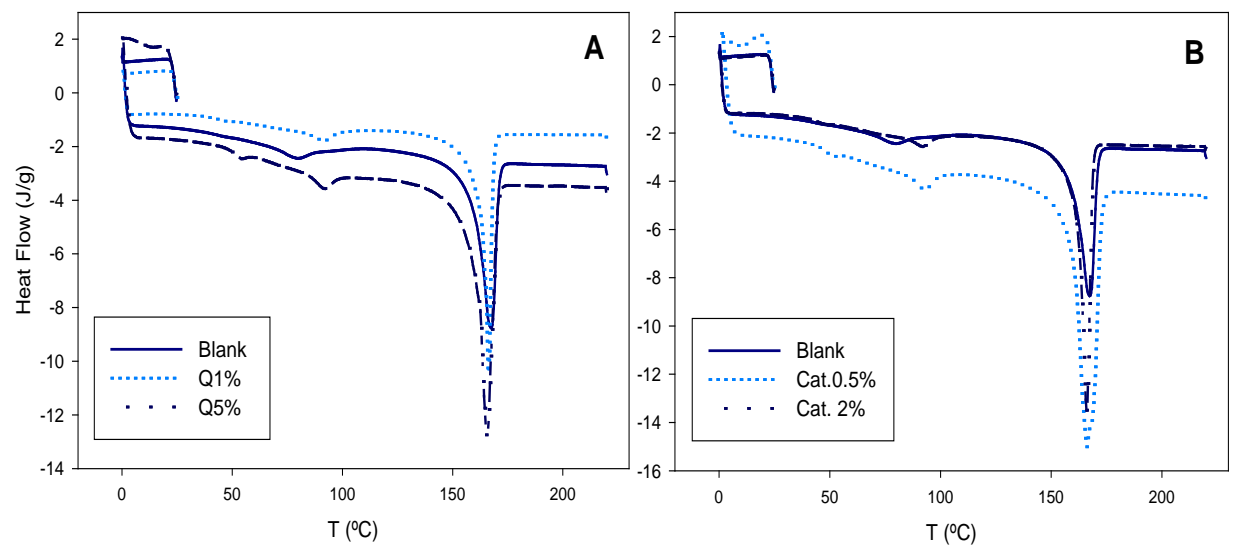

Figure 1.1. $D S C$ thermograms of $E V O H$-based materials during the first heating; $(A)$ values for quercetin-containing films [(-)blank; ( ') Q1\%; and (- - -) Q5\%]; (B) values for catechincontaining films [( $\left(\right.$ )blank; $\left({ }^{-}\right)$Cat.0.5\%; and (- - -)Cat.2\%].

During the cooling process (not shown), the polymer showed a crystallization exotherm at $147{ }^{\circ} \mathrm{C}$. During the second heating (not shown), the glass transition and the melting of crystals were observable at similar temperatures to those of the first heating but there was no sign of the endotherm at $88^{\circ} \mathrm{C}$. In the case of semicristalline/amorphous thermoplastics, processing results in internal molecular stresses (thermal history effects) which are relieved on first heating (Zhang et al., 1999). For all the samples, the release of these stresses appears as an endothermic relaxation event after the glass transition, approximately at around $88^{\circ} \mathrm{C}$.

As can be seen in Figure 1.1 and Table 1.1, the presence of the antioxidants in the polymer did not produce large changes. The glass transition temperatures of the samples were not significantly different $(p<0.05)$, although it would appear that the addition of high concentrations of the flavonoids might result in an increase in polymer rigidity. The melting feature also differed slightly in the materials containing flavonoids. The minimum for the endotherm moved forward significantly in all the antioxidant-containing samples ( $p>0.05$ ). Also, the crystallinity (melting enthalpy) of EVOH samples decreased when high concentrations of the antioxidants were added. 
Table 1.1. Thermal parameters from DSC thermograms of the EVOH-based materials during the first heating.

\begin{tabular}{lcccc}
\hline Sample & $\mathrm{T}_{\mathrm{g}}\left({ }^{\circ} \mathrm{C}\right)$ & $\mathrm{T}_{\mathrm{m}}\left({ }^{\circ} \mathrm{C}\right)$ & $\Delta \mathrm{H}_{\mathrm{m}}(\mathrm{J} / \mathrm{g})$ & $\Delta \mathrm{H}_{\text {mcor }}(\mathrm{J} / \mathrm{g})$ \\
\hline Blank & $43.0 \pm 1.3 \mathrm{a}$ & $167.0 \pm 0.3 \mathrm{a}$ & $-74.8 \pm 1.8$ & $-74.8 \pm 1.8 \mathrm{a}$ \\
Q1\% & $42.5 \pm 1.3 \mathrm{a}$ & $165.7 \pm 0.6 \mathrm{~b}$ & $-75.2 \pm 1.8$ & $-75.9 \pm 1.8 \mathrm{a}$ \\
Q5\% & $50.3 \pm 4.0 \mathrm{~b}$ & $164.9 \pm 0.2 \mathrm{~b}$ & $-70.4 \pm 1.2$ & $-74.1 \pm 1.2 \mathrm{a}$ \\
Cat.0.5\% & $42.7 \pm 1.3 \mathrm{a}$ & $165.4 \pm 0.3 \mathrm{~b}$ & $-74.7 \pm 4.2$ & $-75.1 \pm 4.2 \mathrm{a}$ \\
Cat.2\% & $44.8 \pm 2.5 \mathrm{a}$ & $165.6 \pm 0.1 \mathrm{~b}$ & $-73.0 \pm 1.8$ & $-74.5 \pm 1.8 \mathrm{a}$ \\
\hline
\end{tabular}

$a, b, \ldots$ indicate significant differences among the values of the same thermal property.

However, no significant differences were observed when the enthalpy values were corrected for the percentage of polymer in the sample. Also, Figure 1.1 shows that the width of the transition increased in the samples with flavonoids. A possible interpretation of these differences is that the antioxidant molecules disrupt the crystal structure, resulting in a more heterogeneous structure.

Since the compounds were melt-blended with the polymer at high temperatures, thermogravimetric analyses were performed to determine the degradation temperature of the new materials and the thermal stability of the antioxidants. Figure 1.2 shows that the stability of the polymer was improved by the addition of the natural antioxidants, since the degradation of the resulting materials occurred at higher temperatures.
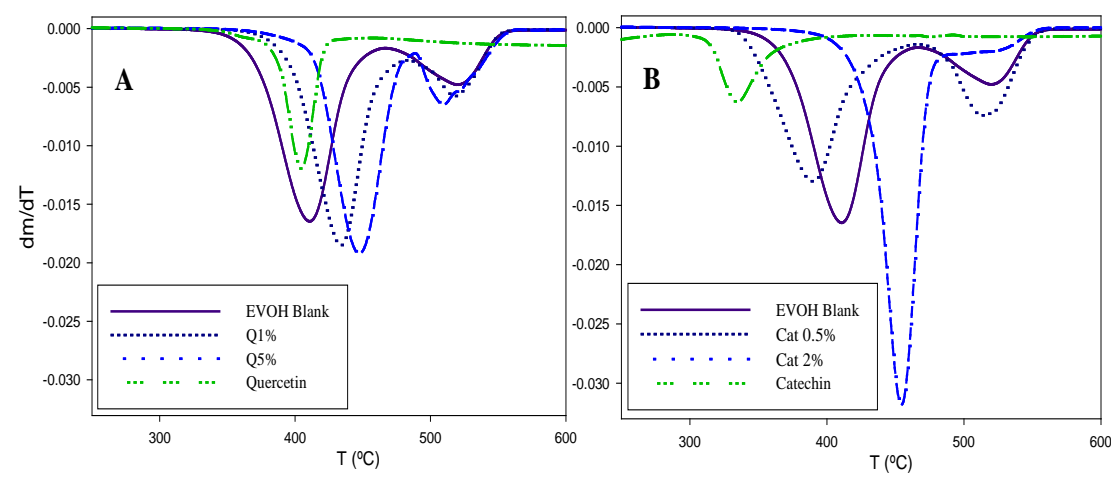
Figure 1.2. Derivative of the weight loss of natural antioxidants and EVOH materials, measured by TGA. $A$, values for quercetin containing films and quercetin. $B$, values for catechin containing films and catechin.

As can be seen in Figure 1.2A, the degradation temperatures of the materials containing quercetin were higher than those of the blank EVOH sample, which degraded at $414{ }^{\circ} \mathrm{C}$, compared to 430 and $447^{\circ} \mathrm{C}$ for 1 and $5 \%$ quercetin respectively. In the case of the catechin-containing samples, shown in Figure $1.2 \mathrm{~B}$, the low concentration sample presented a lower degradation temperature, due to earlier degradation of the catechin, but the higher concentration sample possessed the highest stability: the degradation temperature for the sample with $2 \%$ catechin was $455^{\circ} \mathrm{C}$.

\subsection{Barrier Properties}

\subsubsection{Water vapor permeability}

The water vapor permeability values were measured for all samples at $50 \%$, $75 \%$ and $100 \%$ relative humidity gradients and $23^{\circ} \mathrm{C}$. As can be seen in Table 1.2, the WVP of all samples increased with the RH gradient, showing the plasticizing effect of water on the polymer matrix at high humidities. In dry conditions, strong interchain interactions among EVOH hydroxyl groups result in high cohesive energy and low chain flexibility. In the presence of humidity, sorbed water molecules interact by hydrogen bonding with the $-\mathrm{OH}$ groups of the polymer, reducing the interchain bonding and giving rise to a decrease in the glass transition temperature $\left(T_{g}\right)$ of the polymer and and an increase in its flexibility and permeability to gases and vapors (Aucejo et al., 1999). This effect is in agreement with previous reports in which water permeability was rather constant at low humidity and increased considerably in very humid environments (Aucejo, 2000).

The addition of the antioxidants to EVOH did not produce significant effect on water vapor permeability at $50 \% \mathrm{RH}$. At $100 \% \mathrm{RH}$, the water permeability values of all the samples with active agents incorporated increased up to $30 \%$ with respect to the blank sample. This increment could be a consequence of the more deficient crystallinity of the antioxidant-containing samples. At high 
humidities, the high plasticization of the polymer may increase the areas suitable for transport, including amorphous areas within small and defective crystal structures which are forbidden to transport at low humidities. At $75 \%$ $\mathrm{RH}$, the WVP values of the developed films fell considerably respect to the blank sample, by a factor of 4 . It is known that mass transport kinetics change drastically when a polymer passes from a vitreous to a rubbery state. The presence of the antioxidants may reduce the plasticizing effect of the sorbed water in such a way that the relative humidity at which the $T_{g}$ reaches room temperature increases, delaying the exponential growth of permeability towards higher $\mathrm{RH}$ values.

\subsubsection{Oxygen permeability}

Table 1.2 also shows the oxygen permeability values for EVOH samples. As already commented above, the water sorption of the EVOH samples increased with relative humidity, resulting in plastification of the polymer with a sharp fall in its glass transition temperature $\left(T_{g}\right)$ and an increase in its permeability (Aucejo, 2000; Yamamoto et al., 2009).

The incorporation of antioxidants did not modify the barrier properties notably. At $50 \% \mathrm{RH}$, the samples with antioxidants presented slightly higher oxygen permeability values $(p>0.05)$. This increment could be caused by the already mentioned reduction of the crystalline fraction and the more irregular crystal structure, as observed in the thermal analysis. 
Table 1.2. Water Vapor and Oxygen Permeability Values of EVOH Based Materials.

\begin{tabular}{lccccc}
\hline & \multicolumn{3}{c}{ Water Vapour Permeability } & \multicolumn{2}{c}{ Oxygen Permeability } \\
& \multicolumn{3}{c}{$10^{16} \cdot\left(\mathrm{Kg} \cdot \mathrm{m} /\left(\mathrm{m}^{2} \cdot \mathrm{s} \cdot \mathrm{Pa}\right)\right)$} & \multicolumn{1}{c}{$10^{21} \cdot\left(\mathrm{m}^{3} \cdot \mathrm{m} /\left(\mathrm{m}^{2} \cdot \mathrm{s} \cdot \mathrm{Pa}\right)\right.$} \\
\hline \hline RH 50 & $\mathrm{RH} 75$ & $\mathrm{RH} 100$ & $\mathrm{RH} 50$ & $\mathrm{RH} 90$ \\
\hline & $2.0 \pm 0.1 \mathrm{a}$ & $8.9 \pm 0.6 \mathrm{c}$ & $13.9 \pm 1.0 \mathrm{ab}$ & $7.2 \pm 0.2 \mathrm{a}$ & $33.6 \pm 0.9 \mathrm{~b}$ \\
Q 1\% & $1.7 \pm 0.1 \mathrm{a}$ & $1.9 \pm 0.1 \mathrm{a}$ & $18.3 \pm 1.3 \mathrm{c}$ & $6.7 \pm 0.4 \mathrm{a}$ & $29.4 \pm 0.6 \mathrm{a}$ \\
Q 5\% & $1.7 \pm 0.4 \mathrm{a}$ & $1.7 \pm 0.1 \mathrm{a}$ & $13.2 \pm 1.6 \mathrm{a}$ & $8.0 \pm 0.2 \mathrm{~b}$ & $36.6 \pm 0.3 \mathrm{c}$ \\
Cat 0.5\% & $1.9 \pm 0.2 \mathrm{a}$ & $1.9 \pm 0.2 \mathrm{a}$ & $16.5 \pm 0.9 \mathrm{bc}$ & $7.8 \pm 0.1 \mathrm{~b}$ & $40.2 \pm 0.2 \mathrm{~d}$ \\
Cat 2\% & $1.8 \pm 0.2 \mathrm{a}$ & $5.3 \pm 0.6 \mathrm{~b}$ & $17.1 \pm 3.0 \mathrm{bc}$ & $9.3 \pm 0.4 \mathrm{c}$ & $36.8 \pm 0.4 \mathrm{c}$
\end{tabular}

$a, b, \ldots$ indicate significant differences among the values of permeability at the same $\mathrm{RH}$.

At high humidities, the samples with antioxidants presented increased oxygen permeability values, in agreement with those for water permeability. The presence of the antioxidants may increase the amount of sorbed water and, consequently, polymer plasticization. The samples with catechin, the most hydrophilic antioxidant, are those which present the strongest effect.

From the water and oxygen mass transport results, it can be concluded that the addition of the antioxidants did not modify the barrier properties of the EVOH materials. The materials containing these flavonoids provide a medium permeability to water at low relative humidities and a high permeability in humid environments. With respect to oxygen, the materials maintain their status as very high barrier polymers when dry and high barrier polymers when humid.

\subsection{Optical Properties}

The color parameters of the extruded EVOH films containing catechin (at 0.5 and $2 \% \mathrm{w} / \mathrm{w}$ ) and quercetin (at 1 and 5\%) were analyzed and the results are given in Table 1.3. All the film samples were highly homogeneous and 
transparent, as the luminosity values $(L)$ show. The catechin-containing films presented a light brown color, reflected by the rise in the $a^{*}$ and $b^{*}$ values and the hue angle values falling in the second portion of the first quadrant. The quercetin-containing EVOH materials developed a yellow color as indicated by the hue angle. These samples presented negative $a^{*}$ values (green) and large positive $\mathrm{b}^{\star}$ values (yellow). As shown in Table 1.3, the chroma and $\Delta \mathrm{E}$ values increased with the concentration of each antioxidant in the film.

Table 1.3. Color Parameters of EVOH Based Materials.

\begin{tabular}{|c|c|c|c|c|c|c|}
\hline & $L^{*}$ & $\mathbf{a}^{*}$ & $\mathbf{b}^{*}$ & $\mathrm{C}^{*}$ & $\mathrm{H}\left({ }^{\circ}\right)$ & $\Delta \mathrm{E}$ \\
\hline Blank & $91.1 \pm 1.4 \mathrm{a}$ & $-0.08+0.02 c$ & $-0.05 \pm 0.02 \mathrm{a}$ & $0.10 \pm 0.03 a$ & $29.3 \pm 5.9 \mathrm{~b}$ & - \\
\hline Q 1\% & $92.7 \pm 1.3 \mathrm{a}$ & $-5.3 \pm 0.1 b$ & $11.1 \pm 0.2 \mathrm{~d}$ & $12.3 \pm 0.2 \mathrm{~d}$ & $-64.6 \pm 0.3 a$ & $12.4 \pm 0.2$ \\
\hline Q 5\% & $92.9 \pm 0.8 \mathrm{a}$ & $-11.4 \pm 0.4 \mathrm{a}$ & $28.1 \pm 1.33 \mathrm{e}$ & $30.3 \pm 1.4 \mathrm{e}$ & $-67.8 \pm 0.3 a$ & $18.2 \pm 1.3$ \\
\hline Cat $0.5 \%$ & $92.2 \pm 0.7 \mathrm{a}$ & $0.24 \pm 0.1 \mathrm{~d}$ & $2.5 \pm 0.2 b$ & $2.5 \pm 0.2 b$ & $84.4 \pm 0.7 \mathrm{c}$ & $10.2 \pm 0.1$ \\
\hline Cat $2 \%$ & $91.9 \pm 0.5 a$ & $0.62 \pm 0.1 \mathrm{e}$ & $4.6 \pm 0.6 \mathrm{c}$ & $4.7 \pm 0.6 \mathrm{c}$ & $82.4 \pm 0.2 c$ & $12.3 \pm 0.4$ \\
\hline
\end{tabular}

$\mathrm{a}, \mathrm{b}, \mathrm{c} \ldots$ indicate significant differences among the values of the same color property.

\subsection{Antioxidant release}

The release of antioxidants from the films into different food simulants was monitored during storage at room temperature. Antioxidant release presented a similar profile with all the simulants and antioxidants. Figure 1.3 shows representative evolutions of catechin release at the two concentrations and using ethanol $10 \%$ and water as simulants. The accumulation of antioxidant followed an "exponential growth to a maximum" type of profile, although the extent and kinetics varied markedly between samples.

The first important factor for the release of compounds from the polymer matrix into the simulant was the initial concentration of the antioxidant in the film. In all the tests, and as expected, the higher the initial antioxidant concentration the higher the amount of antioxidant released. 
A second important factor was the food simulant. As can be seen in Figure 1.3, the extent and kinetics of catechin release are higher in the presence of alcohol.

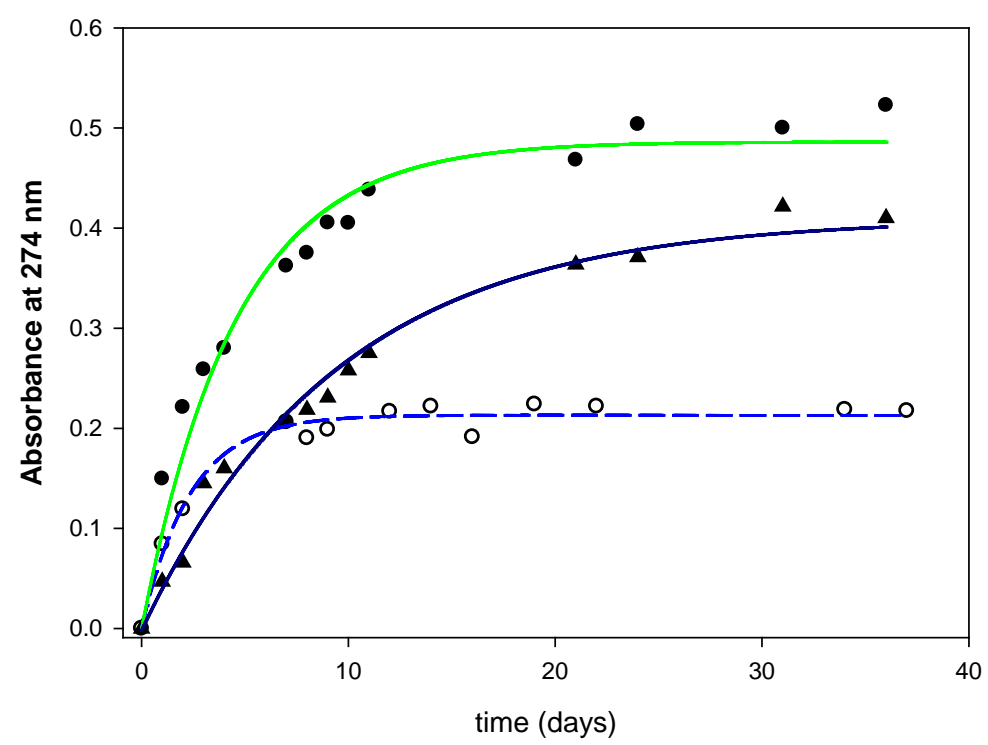

Figure 1.3. Examples of the release of catechin from EVOH based materials, showing the effect of concentration and simulant (water and 10\% ethanol): (•), Cat $2 \%$ into ethanol $10 \%$; (०), Cat $0.5 \%$ into ethanol $10 \%$; and ( $\mathbf{\Delta})$, Cat $2 \%$ into water.

The extent of release at equilibrium (after a lengthy exposure time) depends on the compatibility between the migrant and the simulant. The extent of release can be characterized by the partition coefficient $(K)$, defined as the ratio of the concentration of a compound in the polymeric phase to that in the food simulant. The $K$ values are shown in Figure 1.4. Both antioxidants are highly soluble in ethanol and, therefore, the release of these agents into 95\% ethanol approached full extraction. The $K$ values for both antioxidants were below 100, without significant differences between samples. In contrast, their solubility in water is limited, specially for quercetin, which had a $K$ value well above 10000 . This low compatibility reduces the extent of release considerably. The presence of $10 \%$ of alcohol slightly increases the release of the flavonoids. Release tests were also performed with isooctane, although the 
amount of antioxidant in this simulant, if any, lay below the sensitivity threshold of the technique. The chemical incompatibility between the antioxidants and the isooctane $(K \rightarrow \infty)$ and the lack of plasticization of the polymer (very slow diffusion) are responsible for practically preventing their release.

Figure 1.3 likewise shows that the type of simulant to which the film is exposed can also alter the kinetics of the process. The $D$ coefficient as defined in Fick's laws characterizes the kinetics of transport in polymeric matrices. From the evolution of release during exposure, the $D$ values were calculated by the method of López-Carballo (Lopez-Carballo et al., 2005). Figure 1.3 includes the plots of the theoretical values. It will be seen that they describe the experimental data well, indicating that antioxidant release follows Fick's laws. Figure 1.4 compares the diffusion coefficient values obtained for the two agents and the different food simulants.

It is well known that the presence of high relative humidities results in the plasticization of the polymer, which in turn results in a faster diffusion process. Therefore, one could expect the mass transport to depend on the water gain by the polymer and the release curve not to be described by a model which considers a constant diffusion coefficient.

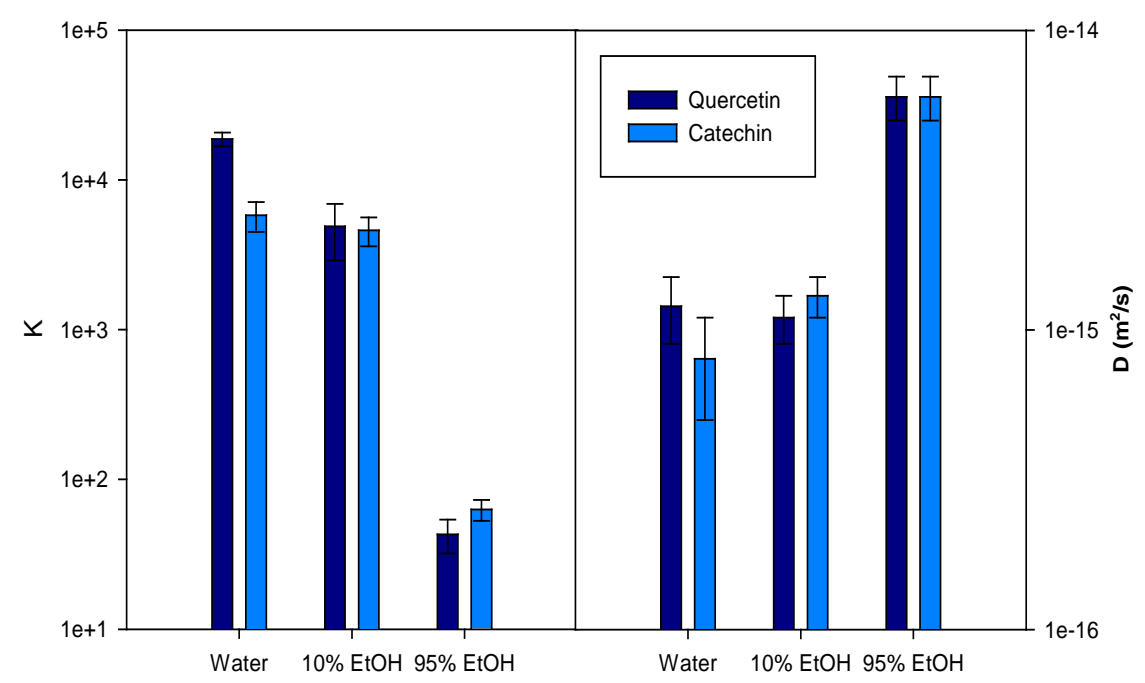


Figure 1.4. Partition (K) and diffusion (D) coefficient values for the release of catechin and quercetin (dark-blue bars) from EVOH based materials into the food simulants tested.

Nevertheless, sorption by the polymer of substances of small molecular size like water is so fast that the mass transport of the flavonoids can be considered to start once the polymer matrix has been plasticized by water. This consideration has been used successfully before, when describing the effect of humidity on the mass transport of $\alpha$-pinene in an ethylene-vinyl alcohol copolymer with 32 molar percentage of ethylene, EVOH32 (LopezCarballo et al., 2005). In that work, the pinene permeability through EVOH32 increased by a factor of 10000 because of humidity. The effect of humidity on $D$ was also severe. In absolute values, however, the measured diffusivity of pinene in EVOH32 exposed to a humid environment was lower than the diffusion of flavonoids in EVOH44 measured in the present study. This difference is probably caused by the difference in ethylene content: there is a 100 factor difference in oxygen permeability between these two copolymers (Yamamoto et al., 2009). Also, immersion in water could be expected to induce far greater plasticization of the polymer than that caused by humid air.

Similar results were observed for diffusion in films exposed to a $10 \%$ ethanol aqueous solution. However, immersion of the sample into 95\% ethanol produced a significant increase in the release rate, as the $D$ values reached the $7 \cdot 10^{-15} \mathrm{~m}^{2} / \mathrm{s}$ range. The plasticizing effect of low molecular weight alcohols on EVOH materials is considered responsible for this effect (Lopez-Carballo et al., 2005). No differences were observed between the $D$ values for the two agents.

The migration of the compounds in isooctane was so low and/or slow that the antioxidant activity, if any, was below the experimental error level. In the films exposed to isooctane, both the low solubility of the antioxidants and the low interaction with the polymer resulted in near-zero release.

To prove that the active films protect the food from oxidation by radicals, the method based on the reduction of DPPH, a stable free radical, was selected to 
evaluate their antioxidant activity in the food simulants, since the free radicalscavenging activity of the phenolic antioxidants incorporated into the films is considered to be due to their hydrogen-donating ability.

The antioxidant activity was observed to be proportional to the antioxidant concentration in the different simulants and showed the same kinetic profile as antioxidant release. Besides the effects of concentration, as already commented, the effect of the food type was clearly noticeable. Films were very active in alcohol containing simulants and showed less activity in aqueous products. However, their activity in contact with fatty food products is uncertain since the values observed in ethanol 95\% and isooctane were clearly divergent. Similar disagreement has been observed in other migration studies (Stoffers et al., 2003).

Table 1.4 compares the maximum antioxidant activity (long term storage) of the food simulants exposed to the antioxidant films. These results refer to the antioxidant activity that a standard 1 litre package made with these films will provide for the packaged product. In water and ethanol 10\% simulants, films with low and high concentration of catechin provided better results comparing to quercetin ones.

Table 1.4. Maximum antioxidant activity, expressed as ascorbic acid concentration, in all food simulants in contact with evoh films containing quercetin and catechin.

\begin{tabular}{lccc}
\hline \multicolumn{4}{c}{ in all food simulants in contact with evoh films containing quercetin and catechin. } \\
\cline { 2 - 4 } & Water & EtOH 10\% & EtOH 95\% \\
\hline Q 1\% & $0.07 \pm 0.03 \mathrm{a}, \mathrm{x}$ & $1.69 \pm 0.72 \mathrm{a}, \mathrm{y}$ & $29.5 \pm 3.26 \mathrm{a}, \mathrm{z}$ \\
Q 5\% & $1.03 \pm 0.79 \mathrm{ab}, \mathrm{x}$ & $4.43 \pm 1.56 \mathrm{ab}, \mathrm{y}$ & $124.71 \pm 8.79 \mathrm{~b}, \mathrm{z}$ \\
Cat 0.5\% & $2.95 \pm 1.36 \mathrm{bc}, \mathrm{x}$ & $4.03 \pm 1.67 \mathrm{ab}, \mathrm{x}$ & $16.48 \pm 3.21 \mathrm{c}, \mathrm{y}$ \\
Cat 2\% & $4.54 \pm 1.8 \mathrm{c}, \mathrm{x}$ & $6.59 \pm 2.57 \mathrm{~b}, \mathrm{x}$ & $84.05 \pm 4.68 \mathrm{~d}, \mathrm{y}$
\end{tabular}

$a, b, c, d$ indicate significant differences among the diverse films in each simulant. $x, y, z$ indicate significant differences among the simulants, in each film. 
The reason for this effect is the above-mentioned higher solubility of catechin in these liquid media. In ethanol 95\%, the antioxidant protection was proportional to the antioxidant concentration in the films since both quercetin and catechin containing films released most of the flavonoid incorporated. Therefore, catechin containing films presented better characteristics for the production of an all-purpose active package.

These results are indicative of active films having been successfully obtained by adding natural antioxidants to hydrophilic EVOH copolymers through an extrusion process. At the flavonoid concentrations tested, the resulting materials maintained the typical properties of $\mathrm{EVOH}$ materials. The films released the active agent as a function of antioxidant concentration and the type of food simulant to which the film was exposed, which thereby acquired antioxidant capacity. The films proved to be active for aqueous and alcoholic food products. However, the activity of the films exposed to fatty foods was ambiguous, since the tests carried out with the two fatty simulants presented opposite outcomes: very high activity in ethanol 95\% and nil for isooctane. Further studies are ongoing to measure the activity of these materials with different real oxygen-sensitive products.

\section{ACKNOWLEDGEMENTS}

The authors acknowledge the financial support of the Spanish Ministry of Science and Innovation, projects AGL2006-02176, AGL2009-08776 and FunC-Food CSD2007-00063, and the C. L-d-D fellowship (FPU program). Mary Georgina Hardinge provided assistance with the English language text.

\section{REFERENCES}

Aucejo, S., (2000). Study and characterization of the humidity effect on the barrier properties of hydrophillic polymeric structures. Ph.D. Dissertation_Univ.Valencia (Spain). 
Aucejo, S., Catala, R., Gavara, R., (2000). Interactions between water and EVOH food packaging films. Food Science and Technology International 6(2), 159-164.

Aucejo, S., Marco, C., Gavara, R., (1999). Water effect on the morphology of EVOH copolymers. Journal of Applied Polymer Science 74(5), 1201-1206.

Balasundram, N., Sundram, K., Samman, S., (2006). Phenolic compounds in plants and agri-industrial by-products: Antioxidant activity, occurrence, and potential uses. Food Chemistry 99(1), 191-203.

Boots, A.W., Haenen, G., Bast, A., (2008). Health effects of quercetin: From antioxidant to nutraceutical. European Journal of Pharmacology 585(2-3), 325-337.

Bruggemann, O., Visnjevski, A., Burch, R., Patel, P., (2004). Selective extraction of antioxidants with molecularly imprinted polymers. Analytica Chimica Acta 504(1), 81-88.

Caner, C., Harte, B., (2005). Effect of high-pressure processing on the migration of antioxidant Irganox 1076 from polypropylene film into a food simulant. Journal of the Science of Food and Agriculture 85(1), 39-46.

Crosby, N.T., (1981). Aspects of analysis and migration of contaminants., in: materials, F.P. (Ed.). London: Applied science publishers Ltd., pp. 106-149.

Dopico-Garcia, M.S., Lopez-Vilarino, J.M., Gonzalez-Rodriguez, M.V., (2005). Determination of antioxidants by solid-phase extraction method in aqueous food simulants. Talanta 66(5), 1103-1107.

Dopico-Garcia, M.S., Lopez-Vilarino, J.M., Gonzalez-Rodriguez, M.V., (2007). Antioxidant content of and migration from commercial polyethylene, polypropylene, and polyvinyl chloride packages. Journal of Agricultural and Food Chemistry 55(8), 3225-3231.

Ercolini, D., Ferrocino, I., La Storia, A., Mauriello, G., Gigli, S., Masi, P., Villani, F., (2010). Development of spoilage microbiota in beef stored in nisin activated packaging. Food Microbiology 27(1), 137-143.

Granda-Restrepo, D.M., Soto-Valdez, H., Peralta, E., Troncoso-Rojas, R., VallejoCordoba, B., Gamez-Meza, N., Graciano-Verdugo, A.Z., (2009). Migration of alphatocopherol from an active multilayer film into whole milk powder. Food Research International 42(10), 1396-1402.

Gutierrez, L., Sanchez, C., Batlle, R., Nerin, C., (2009). New antimicrobial active package for bakery products. Trends in Food Science \& Technology 20(2), 92-99.

ISO2528:1995, (1995). Sheet Materials - Determination of water vapor transmission rate (gravimetric (dish) method).

Leopoldini, M., Russo, N., Chiodo, S., Toscano, M., (2006). Iron chelation by the powerful antioxidant flavonoid quercetin. Journal of Agricultural and Food Chemistry 54(17), 6343-6351.

Lopez-Carballo, G., Cava, D., Lagaron, J.M., Catala, R., Gavara, R., (2005). Characterization of the interaction between two food aroma components, alphapinene and ethyl butyrate, and ethylene-vinyl alcohol copolymer (EVOH) packaging films as a function of environmental humidity. Journal of Agricultural and Food Chemistry 53(18), 7212-7216. 
Lopez-Rubio, A., Almenar, E., Hernandez-Munoz, P., Lagaron, J.M., Catala, R., Gavara, R., (2004). Overview of active polymer-based packaging technologies for food applications. Food Reviews International 20(4), 357-387.

Lopez-Rubio, A., Lagaron, J.M., Gimenez, E., Cava, D., Hernandez-Munoz, P., Yamamoto, T., Gavara, R., (2003). Morphological alterations induced by temperature and humidity in ethylene-vinyl alcohol copolymers. Macromolecules 36(25), 9467-9476.

López-Vilariño, J., Noguerol, C., Villaverde, M., Sabín, J., González, M.V., (2006). Addition of natural antioxidants to polyolefins formulations., Addcon World Rapra Technology, Cologne (Germany).

Lu, P.C., (1984). Phenolic antioxidant-polymeric resin compositions and method.

Martínez-Florez, S., González-Gallego, J., Culebras, J.M., Muñon, M.J., (2002). Los flavonoides: propiedades y acciones antioxidantes. Nutr.Hosp. XVII (6), 271-278.

Moore, M.E., Han, I.Y., Acton, J.C., Ogale, A.A., Barmore, C.R., Dawson, P.L., (2003). Effects of antioxidants in polyethylene film on fresh beef color. Journal of Food Science 68(1), 99-104.

Nakanishi, I., Miyazaki, K., Shimada, T., Ohkubo, K., Urano, S., Ikota, N., Ozawa, T., Fukuzumi, S., Fukuhara, K., (2002). Effects of metal ions distinguishing between one-step hydrogen- and electron-transfer mechanisms for the radical-scavenging reaction of (+)-catechin. Journal of Physical Chemistry A 106(46), 11123-11126.

Nerín, C., Astudillo Campillo, M., Covian Sanchez, I., Mújica, G.R., Garai, R.M., Sanchez, I.C., (2007).

Nerín, C., Tovar, L., Djenane, D., Camo, J., Salafranca, J., Beltran, J.A., Roncales, P., (2006). Stabilization of beef meat by a new active packaging containing natural antioxidants. Journal of Agricultural and Food Chemistry 54(20), 7840-7846.

Okada, Y., Okada, M., (1998). Scavenging effect of water soluble proteins in broad beans on free radicals and active oxygen species. Journal of Agricultural and Food Chemistry 46(2), 401-406.

Pedrielli, P., Pedulli, G.F., Skibsted, L.H., (2001). Antioxidant mechanism of flavonoids. Solvent effect on rate constant for chain-breaking reaction of quercetin and epicatechin in autoxidation of methyl linoleate. Journal of Agricultural and Food Chemistry 49(6), 3034-3040.

Peltzer, M., Wagner, J., Jimenez, A., (2009). Migration study of carvacrol as a natural antioxidant in high-density polyethylene for active packaging. Food Additives and Contaminants Part a-Chemistry Analysis Control Exposure \& Risk Assessment 26(6), 938-946.

Perez-Lamela, C., Rijk, R., Simal-Gandara, J., (1998). Stability of the secondary antioxidant bis(2,4-di-tert-butylphenyl)pentaerythritol diphosphite in food simulants. Journal of Agricultural and Food Chemistry 46(2), 687-691.

Sendra, J.M., Sentandreu, E., Navarro, J.L., (2007). Kinetic model for the antiradical activity of the isolated p-catechol group in flavanone type structures using the free stable radical 2,2-diphenyl-1-picrylhydrazyl as the antiradical probe. Journal of Agricultural and Food Chemistry 55(14), 5512-5522. 
Stoffers, N.H., Dekker, M., Linssen, J.P.H., Stormer, A., Franz, R., (2003). Alternative fatty food simulants and diffusion kinetics of nylon 12 food packaging. Food Additives and Contaminants 20(10), 949-959.

Tovar, L., Salafranca, J., Sanchez, C., Nerin, C., (2005). Migration studies to assess the safety in use of a new antioxidant active packaging. Journal of Agricultural and Food Chemistry 53(13), 5270-5275.

Wessling, C., Nielsen, T., Leufven, A., Jagerstad, M., (1999). Retention of alphatocopherol in low-density polyethylene (LDPE) and polypropylene (PP) in contact with foodstuffs and food-simulating liquids. Journal of the Science of Food and Agriculture 79(12), 1635-1641.

Yamamoto, T., Kanda, T., Nishihara, Y., Ooshima, T., Saito, Y., (2009). Correlation Study among Oxygen Permeability, Molecular Mobility, and Amorphous Structure Change of Poly(ethylene-vinylalcohol copolymers) by Moisture. Journal of Polymer Science Part B-Polymer Physics 47(12), 1181-1191.

Zhang, Z.B., Britt, I.J., Tung, M.A., (1999). Water absorption in EVOH films and its influence on glass transition temperature. Journal of Polymer Science Part BPolymer Physics 37(7), 691-699. 
Artículo 2

\title{
REDUCING OXIDATION OF FOODS THROUGH ANTIOXIDANT ACTIVE PACKAGING BASED ON EVOH AND NATURAL FLAVONOIDS
}

\author{
Carol López-de-Dicastillo, Davinson Pezo, Cristina Nerín, \\ Gracia López-Carballo, Ramón Catalá, Rafael Gavara \\ and Pilar Hernández-Muñoz
}

Submitted to Innovative Food Science and Emerging Technologies 


\section{ABSTRACT}

The development of antioxidant active packaging systems is attracting considerable attention as one of the preferred emerging technologies for reducing the incidence of lipid peroxidation. This work presents the use of ethylene-vinyl alcohol copolymer films containing two natural flavonoids, catechin and quercetin, to reduce the oxidation of food. In a series of experiments, these materials showed their ability to reduce the presence of hydroxyl radicals in the package headspace. Packaging fried peanuts in bags manufactured with these active films resulted in a large reduction in the presence of hexanal, a compound produced during peroxidation of the unsaturated fat in peanuts. The results indicated that the materials actively reduced the presence of radical oxidative species even though the antioxidants are not released into the food. On exposing sunflower oil to the films, the peroxide values obtained showed that the films actively protected the oil; because of the higher solubility of quercetin in this food product, the samples containing this flavonoid were more efficient.

Industrial relevance: Active packaging is receiving considerable attention as an emerging technology that can be used to improve the quality and stability of food, reducing the direct addition of chemicals and the need for changes in formulation. The results of this study show that it is possible to reduce food oxidation without adding antioxidants to the food. The films obtained can be used to protect any type of food, including dry or fatty products.

Keywords: antioxidant, active packaging, quercetin, catechin, EVOH, oil, peanuts, radical species 


\section{INTRODUCTION}

Lipids are found naturally in most biological materials consumed as food and are added as functional ingredients to many processed foods. They provide the food with many desirable qualities, including texture, structure, mouth feel, flavour and colour attributes. However, lipids are also among the most chemically unstable of food components and will readily undergo thermodynamically-favourable free-radical chain reactions that not only deteriorate the lipids but also: i) produce oxidative fragments, some of which are volatile and, with their characteristic soapy smell, are perceived as rancid off-flavours, ii) degrade proteins, vitamins and pigments and iii) cross-link lipids and other macromolecules into non-nutritive polymers.

The addition of antioxidants and the design of a suitable packaging technology are the two most common options for reducing oxidation in sensitive food products. Antioxidants are added to food to slow the oxidation rate; if used and stored properly, they can extend the shelf life of the product. Natural antioxidants are preferred to artificial substances, especially by consumers (Martin-Diana, Rico, \& Barry-Ryan, 2008). Vacuum or modified atmosphere packaging combined with high barrier packaging materials can limit the presence of oxygen, although it is not always completely and effectively eliminated because of a residual presence at the time of packing or because it permeates in from the exterior through the package wall (Rooney, 1995). Moreover, some food products such as fresh red meat cannot be packaged without oxygen. Currently, other strategies are being considered, including the use of active antioxidant packages (Lopez-Rubio, Almenar, HernandezMunoz, Lagaron, Catala, \& Gavara, 2004; Mastromatteo, Barbuzzi, Conte, \& Del Nobile, 2009; Moore, Han, Acton, Ogale, Barmore, \& Dawson, 2003; Nerín, et al., 2006; Nerin, Tovar, \& Salafranca, 2008).

Active packaging is an emerging technology that employs a packaging material or device which interacts with the environment and the product to extend shelf life. The use of active antioxidant packages that incorporate natural antioxidants presents important advantages. On the one hand, the 
addition of a natural antioxidant to the package may reduce the need to use synthetic antioxidants in the plastic, reducing the risk of potential toxicity by migration. Some initial studies have proved that polyphenolic compounds, such as catechin or epicatechin, can replace synthetic antioxidants in protecting the package contents (López-Vilariño, Noguerol, Villaverde, Sabín, \& González, 2006). Equally, the extra protection of the food provided by the active package can make it possible to reduce the direct addition of chemicals to the food. Nerin et al., (2006) reported an increased stability of meat through active packaging with materials containing plant extracts. Peltzer et al. (2009) measured the release of carvacrol from a polyethylene film. Pereira de Abreu et al. (2011) used a film with a barley extract to reduce oxidation in frozen blue shark. Granda-Restrepo et al. (2009) developed polyethylene films containing alpha-tocopherol and measured the release of the antioxidant into milk powder.

Many phenolic compounds commonly found in plants, such as carvacrol, thymol or sesamol, have been reported to possess multiple biological effects including antioxidant activity (Konsoula \& Liakopoulou-Kyriakides, 2010; Viuda-Martos, Ruiz-Navajas, Fernandez-Lopez, \& Perez-Alvarez, 2009; Yanishlieva, Marinova, Gordon, \& Raneva, 1999). However, many of these plant constituents are volatile and difficult to use in conventional packaging manufacturing processes (extrusion and injection). Although other processing strategies employing less severe thermal treatments can be used (Garces, Nerin, Beltran, \& Roncales, 2004), volatile agents are released into the atmosphere during storage, so film aging reduces the effectiveness of the active materials. Flavonoids, a class of polyphenols, are mainly present in fruits and vegetables and have received considerable attention in recent years because of their high antioxidant activity (Pekkarinen, Heinonen, \& Hopia, 1999). Quercetin and catechin are commonly found in both edible and nonedible plants. These phenolic compounds have been reported to possess multiple biological effects, including high antioxidant activity. The antioxidant activity of phenolic compounds is due to their ability to scavenge free radicals, 
donate hydrogen atoms or electrons or chelate metal cations as a result of their chemical structure (Boots, Haenen, \& Bast, 2008; Martínez-Florez, González-Gallego, Culebras, \& Muñon, 2002; Pedrielli, Pedulli, \& Skibsted, 2001).

Besides their antioxidant character, these two flavonoids were selected because a) they are non-volatile, reducing the loss of agent during packaging manufacturing that occurs with other compounds such as BHT or carvacrol, b) they could protect the polymer during processing and overall, and c) because when released into food, they increase the bioactive compound content of the product instead of constituting a toxicological risk as occurs with synthetic antioxidants.

The development of EVOH-based films containing the flavonoids catechin and quercetin was reported in an earlier work (Lopez-de-Dicastillo, Alonso, Catala, Gavara, \& Hernandez-Munoz, 2010) which also characterized their functional properties, including release of the antioxidants into food. The results revealed that the films presented high antimicrobial activity when exposed to aqueous or alcohol-based liquid foods. This activity was based on strong plasticization of the polymeric matrix owing to its highly hydrophilic nature (Aucejo, Catala, \& Gavara, 2000; Aucejo, Marco, \& Gavara, 1999; Lopez-Rubio, et al., 2003) and on the solubility of catechin and quercetin in these liquid media. No release was observed when the films were exposed to isooctane, a solvent used as a fatty food simulant.

The present work was undertaken to characterize the antioxidant activity of EVOH-based films containing two natural flavonoids, quercetin and catechin, when exposed to solid dry food and to fatty food. The ability of these films to scavenge hydroxyl radicals from the package headspace was measured using Pezo's method (Pezo, Salafranca, \& Nerin, 2008) and the effect of the films on the oxidation stability of fried peanuts and sunflower oil was then determined. 


\section{MATERIALS AND METHODS}

\subsection{Chemicals and Reagents}

Ethylene vinyl alcohol copolymer with a $44 \%$ ethylene molar content (EVOH) was kindly supplied by The Nippon Synthetic Chemical Company, (Osaka, Japan). Quercetin dihydrate, chloroform, acetic acid, potassium iodide and hexanal were purchased from Sigma (Madrid), and (+) catechin hydrate, sodium thiosulphate 5-hydrate and starch were purchased from Fluka (Barcelona).

Fried peanuts and refined sunflower oil were acquired from a local supermarket (Mercadona, Valencia, Spain).

\subsection{Film Preparation}

EVOH films containing 1 and 5\% of quercetin (Q1\% and Q5\%) and 0.5 and $2 \%$ of catechin (Cat $0.5 \%$ and Cat $2 \%$ ) were obtained by flat extrusion. The antioxidants were melt-mixed into the EVOH using a Brabender DSE 20/40 corotating twin-screw extruder (Plastograph, Dusseldorf, Germany) at $200{ }^{\circ} \mathrm{C}$ with a screw speed of $100 \mathrm{rpm}$. Films without an antioxidant (Blank), were also obtained as a polymer control. The resulting films were approximately 40-50 $\mu \mathrm{m}$ thick, although the thickness of every sample was individually measured before the tests with a digital Mitutoyo micrometer (Metrotec, San Sebastian, Spain).

The film samples obtained were vacuum packaged in aluminium/LDPE bags and stored at room temperature until the moment of analysis or application to food.

\subsection{Analysis of hydroxyl radical scavenging activity}

The radical scavenging efficiency of the materials was determined through the method developed by Pezo et al. (Pezo, Salafranca, \& Nerin, 2006; Pezo, et al., 2008). In brief, bags were made from all the materials produced, with internal dimensions of $17.5 \mathrm{~cm} \times 9.5 \mathrm{~cm}$ and a total headspace volume of 194 
$\mathrm{ml}$. A gas stream containing hydroxyl radicals was generated by photolysis of a finely nebulized aerosol of aqueous hydrogen peroxide solution with $254 \mathrm{~nm}$ UV light, thus obtaining an $\mathrm{OH}$ • enriched atmosphere. This gas stream containing hydroxyl radicals was flowed through the bags to be tested and the out-stream containing the $\mathrm{OH} \cdot$ radicals which were not scavenged was bubbled into a solution of salicylic acid at $\mathrm{pH}$ 4.5. This compound reacts with the $\mathrm{OH} \bullet$ radicals to produce 2,5-dihydroxybenzoic acid. The reaction mechanism between $\mathrm{OH}$ - radicals and salicylic acid via an intermediate hydroxylcyclohexadienyl radical is well known (Saran \& Summer, 1999). The concentrations of these compounds were monitored over time by reverse phase HPLC using UV and fluorescence detectors connected in series. Details of the method can be found elsewhere (Pezo, et al., 2006).

In order to measure the antioxidant capacity of the materials, two different series of measurements were carried out. The first was based on total antioxidant activity after 48 hours. In the second set of experiments, hydroxylation measurements were taken periodically, after 3, 6, 9, 12 and 24 hours.

\subsection{Antioxidant effect on food}

\subsubsection{Analysis of oxidation in packaged peanuts}

The oxidation of fried peanuts packaged in bags manufactured with the films was monitored through the accumulation of hexanal in the package headspace (Han, Hwang, Min, \& Krochta, 2008; Pastorelli, Valzacchi, Rodriguez, \& Simoneau, 2006). $10 \times 10 \mathrm{~cm} 2$ bags were prepared with a Sealboy heatsealer (Roveblock, Barcelona, Spain), filled with $30 \mathrm{~g}$ of fried peanuts, thermosealed and stored in the dark at $37^{\circ} \mathrm{C}$ for 40 days. The headspace was atmospheric air. 4 bags were prepared for each type of film. A self-adhesive septum was stuck on each bag for sampling.

In agreement with the literature, hexanal was identified as the most important volatile component in the package headspace in a prior GC-MS analysis. 
The concentration of hexanal in the headspace of the bags was quantified by gas chromatography with flame ionization detection (GC-FID) at different moments throughout the storage time. A Supelco 65- $\mu$ m DVB/PDMS solid phase micro extraction (SPME) fibre (Teknokroma, Barcelona, Spain) was exposed to the bag headspace for $10 \mathrm{~min}$ and immediately desorbed for 10 min in the injector of a HP5890 gas chromatograph (Agilent Technologies, Barcelona, Spain) equipped with a $30 \mathrm{~m}, 0.32 \mathrm{~mm}, 0.25 \mu \mathrm{m}$ TRB-MetaX5 capillary column (Teknokroma, Barcelona, Spain). The chromatographic conditions were as follows: $\mathrm{He}$ as the carrier gas, splitless injection, 210 and $300^{\circ} \mathrm{C}$ injector and detector temperatures, $5 \mathrm{~min}$ at $40^{\circ} \mathrm{C}$, first heating ramp to $60{ }^{\circ} \mathrm{C}$ at $3{ }^{\circ} \mathrm{C} / \mathrm{min}$, second heating ramp to $200^{\circ} \mathrm{C}$ at $10^{\circ} \mathrm{C} / \mathrm{min}$, and $5 \mathrm{~min}$ at $200{ }^{\circ} \mathrm{C}$. No calibration curves were constructed, therefore the results are expressed as peak area units.

\subsubsection{Analysis of oxidation in sunflower oil.}

Samples of $80 \mathrm{~g}$ of sunflower oil and $24 \mathrm{~cm} 2$ of the active films (relation 6 $\mathrm{dm} 2 / \mathrm{L}$ ) were placed in $100 \mathrm{~mL}$ glass vials with twist-off caps and stored in the dark at $37{ }^{\circ} \mathrm{C}$ for 150 days. The oxidation process was monitored by withdrawing samples at intervals and determining the peroxide values, PV, following the standard AOAC iodometric method with some modifications. The peroxide value was determined by measuring the amount of iodine formed by the reaction of peroxides (formed in fat or oil) with the iodide ion.

$2 \mathrm{~g}$ of the sample were weighed, $10 \mathrm{~mL}$ of chloroform and $15 \mathrm{~mL}$ of acetic acid were added to dissolve the sample, and $1 \mathrm{~mL}$ of saturated potassium iodide was added. The mixture was then closed, stirred for 1 minute and kept in the dark for 5 minutes. $75 \mathrm{~mL}$ of water and $1 \mathrm{~mL}$ of a starch solution at $1 \%$ were then added and the final mixture was titrated with $0.002 \mathrm{~N}$ or $0.01 \mathrm{~N}$ sodium thiosulphate depending on the degree of oxidation. Peroxide values were calculated by the following equation:

$$
\mathrm{PV}=\mathrm{V} \cdot \mathrm{N} \cdot 1000 / \mathrm{m}
$$


where $V$ is the volume of sodium thiosulphate used in the assay $(\mathrm{mL}), \mathrm{N}$ is the normality of the sodium thiosulfate $(\mathrm{mmol} / \mathrm{mL})$ and $\mathrm{m}$ is the mass of the sample used in the assay (g). The results are expressed as $\mathrm{O}_{2}$ mequiv / $\mathrm{kg}$ fat.

\section{RESULTS AND DISCUSSION}

The development of EVOH-based films containing the flavonoids catechin and quercetin and the characterization of their functional properties was reported in an earlier work (Lopez-de-Dicastillo, et al., 2010). The transparent films obtained were slightly brown (catechin) or yellow (quercetin) and presented similar thermal properties and permeability to water and oxygen to those of pure EVOH films. Analysis of the films by the DPPH method revealed that the final concentrations ( $w / w)$ in films were $0.72 \pm 0.02 \%(Q 1 \%), 4.01 \pm 0.05 \%$ (Q5\%), $0.33 \pm 0.01 \%$ (Cat0.5\%) and $1.34 \pm 0.02$ (Cat2\%). By exposing the films to the EU food simulants, it was shown that antioxidant release was dependent on the type of food and followed Fickian behaviour: the higher the solubility of antioxidants on the food simulant, the higher the release observed. For this reason, it was observed that there was no release of antioxidant into isooctane, an alternative fatty food simulant. Also, negligible release into solid food products could be expected due to the non-volatile nature of the agent and the very limited surface contact between the film and a granular solid food. In the present study, the films were tested for antioxidant activity in the two scenarios of protecting fried peanuts and protecting oily products.

\subsection{Hydroxyl radical scavenging activity results}

Since the flavonoids incorporated into the films are not volatile, the only way in which the active films can protect a solid food is by scavenging oxidative radicals from the package headspace. To determine whether the films provide any protection for this type of product, the scavenging activity of the films was analysed by measuring the reduction of hydroxyl radicals in the vapour phase using Pezo's method (Pezo, et al., 2008). As Pezo et al. employed this method to determine the activity of films containing volatile antioxidant compounds from plant extracts, the activity measured could be the result of reactions with 
the radicals in the headspace, but another possibility is that the gas stream could carry the antioxidant released from the films into the salicylic acid solution, effectively increasing the antioxidant capacity of the solution.

In the first test, conducted to check whether Pezo's method was applicable to the EVOH films containing flavonoids, the bags were exposed to the hydroxyl radical enriched air stream for 48 hours (Figure 2.1). After this time, the salicylic acid was fully hydroxilated in the blank sample and in the one containing $5 \%$ of quercetin. This showed that the experimental time was too long, since the number of radicals that reached the final solution was higher than the maximum amount which could react with the acid. Nevertheless, the other three film materials presented hydroxyl scavenging activity of up to $40 \%$ compared to the blank samples; for both antioxidants, the materials were more efficient at the lower concentration. This result proved the validity of the methodology for testing the antioxidant activity of non-releasing active systems.

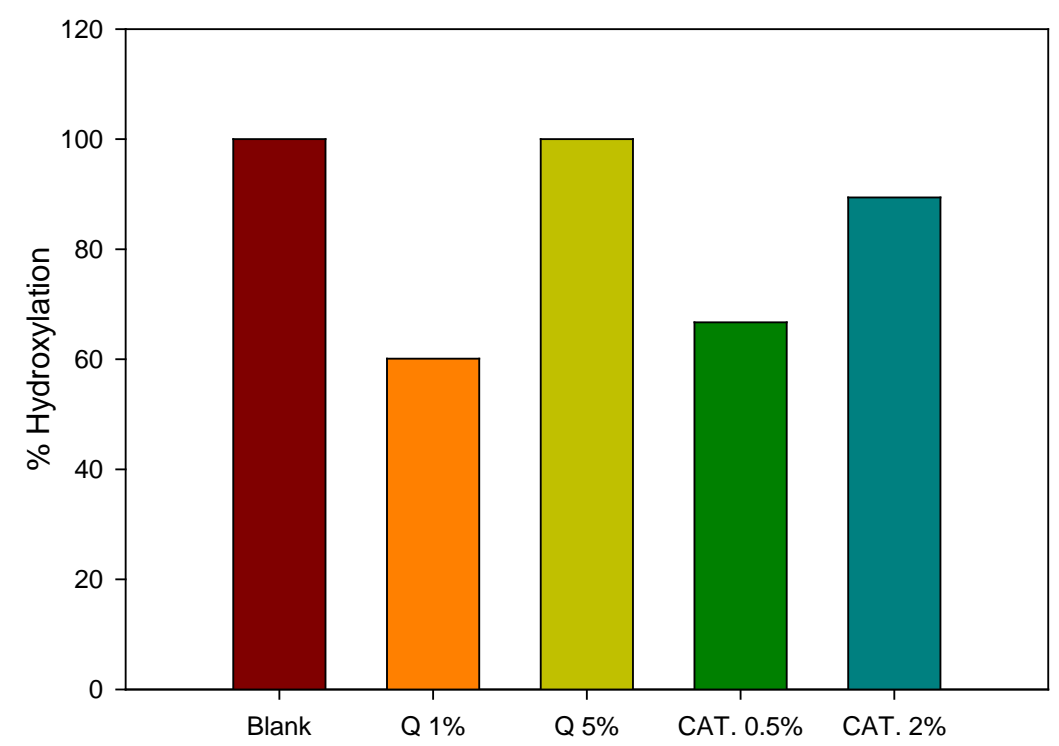

Figure 2.1. Percentage of salicylic acid hydroxylation after 48 hours' exposure of the developed film to a gas stream enriched with hydroxyl radicals (Pezo's method). 
To monitor the antioxidant activity over the storage time, a second test was carried out to measure the hydroxylation reaction after 3, 6, 9, 12 and 24 hours. As Figure 2.2 shows, and as in the first experiment, this method was able to measure antioxidant activity in the materials. Compared to the blank bags, all the flavonoid-containing materials were able to bring about a significant reduction in the number of hydroxyl radicals which reached the final salicylic acid solutions. The best behaviour was observed in the samples containing $1 \%$ quercetin and $0.5 \%$ catechin, which respectively achieved $63 \%$ and 59\% reductions in hydroxyl radicals compared to the blank sample after 9 hours of exposure. The samples with $5 \%$ quercetin and $2 \%$ catechin samples, although less efficient than Q1\% and Cat 0.5\%, also displayed radical reduction activity. The maximum reduction of radicals caused by these two samples was ca. $16 \%$ after 6 hours of exposure.

These results indicate that the flavonoid materials could provide active protection of oxygen-sensitive food products despite the fact that no antioxidant agents are released into the food, as the extruded EVOH-based materials were found to scavenge free radicals from the headspace, improving the food protection afforded by the packaging. To confirm these data, tests with real oxygen-sensitive products were designed.

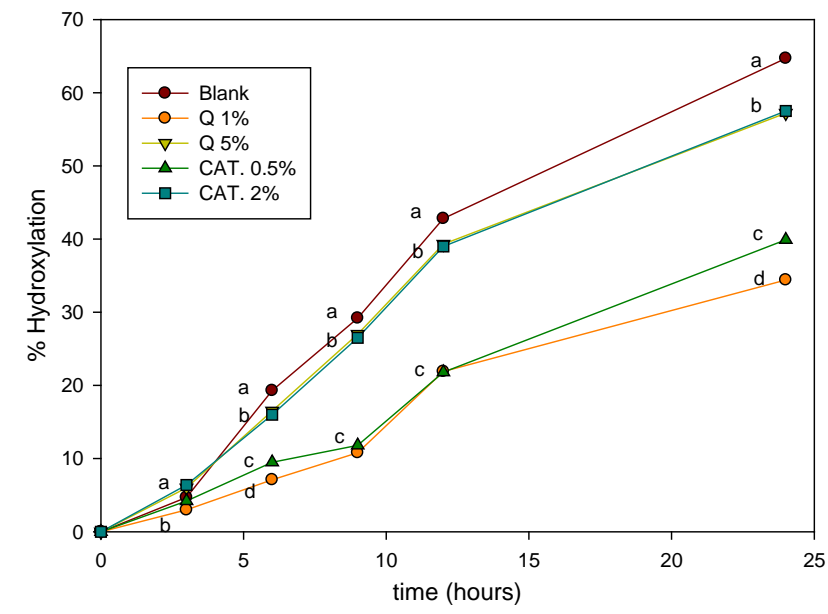

Figure 2.2. Antioxidant activity of extruded films containing quercetin and catechin according to their hydroxyl radical scavenging capacity over time. 


\subsection{Antioxidant activity results on food}

\subsubsection{Peanuts}

Lipids are the major components of peanuts and approximately $80 \%$ of them are unsaturated. Lipid oxidation of packaged peanuts leads indirectly to the accumulation of aliphatic aldehydes, ketones and alcohols, (Burroni, Grosso, \& Guzman, 1997; Wambura \& Yang, 2010; Williams, Duncan, Williams, Mallikarjunan, Eigel, \& O'Keefe, 2006). Oxidation products and rancid flavours decrease the sensory quality of peanut products at very low concentrations, making them unacceptable to consumers even before the end of their shelf life. Hexanal is one of the principal volatile compounds formed during the oxidative degradation of linoleic acid, a polyunsaturated fatty acid present in peanuts, and is usually selected as an indicating chemical for the oxidation of peanuts (Han, et al., 2008; Pastorelli, et al., 2006).

In the present study, fried peanuts were packaged in atmospheric air in bags manufactured with the EVOH films obtained, which were closed and stored at $37^{\circ} \mathrm{C}$ for 40 days to accelerate lipid oxidation. The evolution of hexanal concentration in the package headspace was monitored during storage and the results are plotted in Figure 2.3. As can be seen, the hexanal concentration in the package headspace increased with the storage time as a consequence of the peroxidation of unsaturated fatty acids in all the samples, although the accumulation of hexanal was dependent on the package film. The plot shows that the control samples presented the highest oxidation rate, with a large accumulation of hexanal in the headspace at very early stages of storage. The samples with $1 \%$ quercetin and 0.5 and $2 \%$ catechin displayed the best behaviour. As can be seen, the first significant increment in hexanal concentration was observed on day 25 for these three samples, after which the hexanal increased at the same rate as the control and $5 \%$ quercetin samples, although the accumulated hexanal was significantly lower throughout the experiment. No difference was observed between bags manufactured with $\mathrm{EVOH}$ containing $1 \%$ quercetin or $0.5 \%$ catequin at any time of storage. 


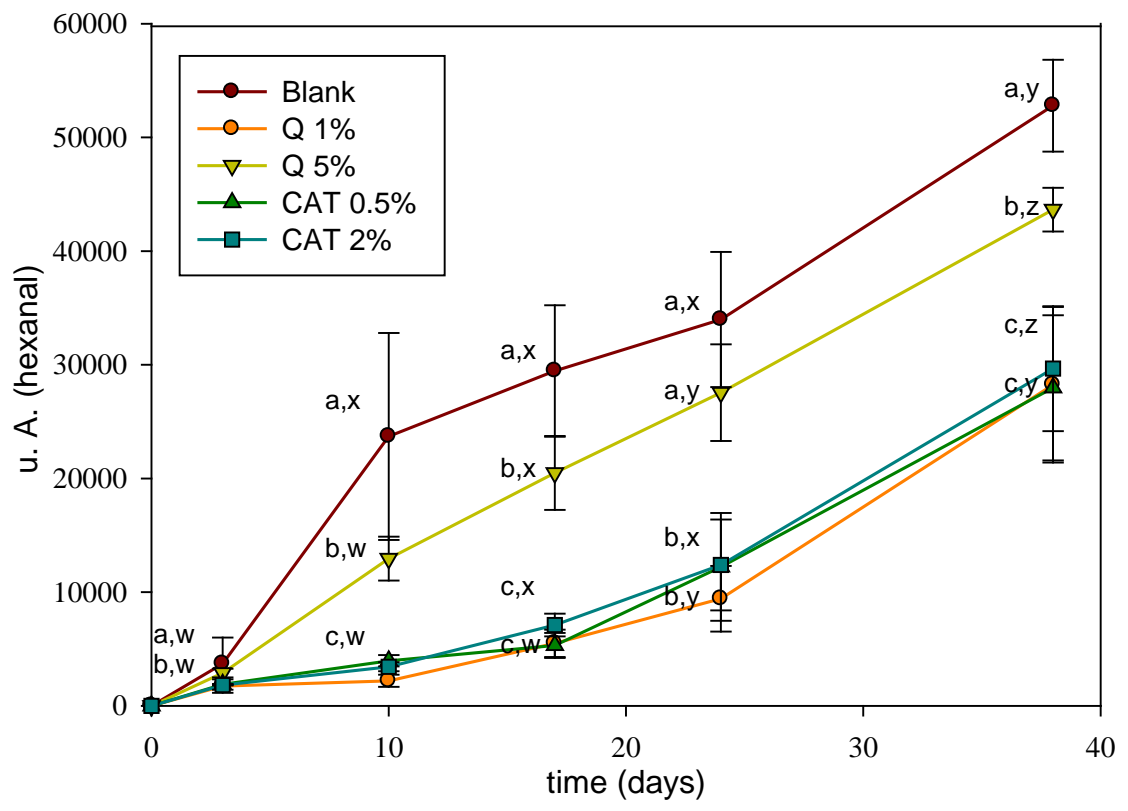

Figure 2.3. Evolution of hexanal concentration in the headspace of packaged peanuts, $(a, b$, $c, \ldots$ indicate significant differences in hexanal content between samples at the same day, and $x, y, .$. indicate significant differences in hexanal content for the same storage time).

The $2 \%$ catechin sample was less efficient at reducing oxidation after day 17 , scoring higher hexanal values than the other two samples in this group. The sample with $5 \%$ quercetin presented intermediate protection. This material significantly reduced the oxidation of the peanuts, especially during the first week (45\% reduction in hexanal presence on day 10). After 10 days the presence of hexanal increased significantly with storage time, although it was still lower than that of the control sample.

These results were in good agreement with the data obtained by the hydroxyl radical scavenging method. In both tests, the materials with $5 \%$ quercetin presented the lowest antioxidant activity. This unexpected result might be correlated to excessive antioxidant concentration. Several studies have shown that tocopherol exhibits its greatest antioxidant potency at lower concentrations and at high concentrations these decrease, or it even exhibits 
prooxidant behaviour (Huang, Frankel, \& German, 1994; Jung \& Min, 1990; Zuta, Simpson, Zhao, \& Leclerc, 2007). Similar results have been reported for ascorbic acid, phenolic compounds including quercetin and their combination (Abou Samra, Chedea, Economou, Calokerinos, \& Kefalas, 2011; Lopez-deDicastillo, Balasubramanian, Yam, \& Schaich, 2009).

\subsubsection{Sunflower oil}

The peroxide index (PV) was used to monitor the effect of the films on the oxidation of sunflower oil. Figure 2.4 plots the evolution of this index for the different samples over 5 months. As can be seen, the PV increased continuously with time for all samples, in agreement with the reported oxidative evolution of this oil in open containers (Martin-Polvillo, Marquez-Ruiz, \& Dobarganes, 2004). This evolution was observed in all the samples, although the rate of increase differed according to the packaging film.

The oil sample packaged in the bag manufactured with plain EVOH (blank) presented the highest peroxide value at all the storage times tested. Differences began to be significant after 40 days' storage for samples containing quercetin. After that point, these two samples presented the lowest hydroperoxide content, with the Q5\% sample as the most efficient. The results for the oil samples packaged in films containing catequin were always in between those of the blank and quercetin samples. Nevertheless, the differences were not significant until the $5^{\text {th }}$ month. These antioxidant efficiencies differ from the results obtained in the hydroxyl radical scavenging test and the peanut stability test. In those assays, the materials were tested to determine whether the films were able to reduce the presence of radicals in the vapour phase.

In a previous work, it was demonstrated that the release and antioxidant activity of these materials into aqueous food products followed Fickian behaviour and were dependent on the solubility of antioxidants in the food simulant (Lopez-de-Dicastillo, et al., 2010). 


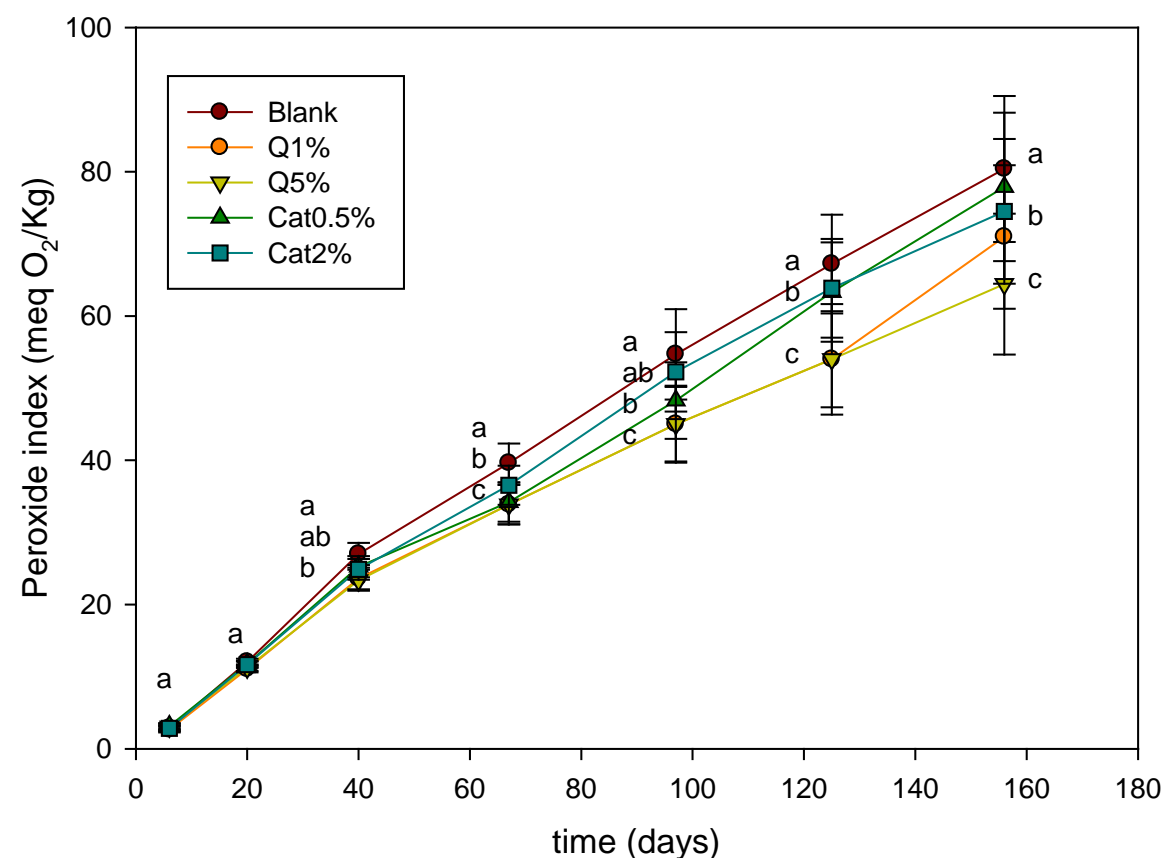

Figure 2.4. Peroxide value $\left(\mathrm{O}_{2}\right.$ mequiv/ $\mathrm{Kg}$ fat $)$ measured in sunflower oil exposed to the films over time $(a, b, c, \ldots$ indicate significant differences in hexanal content between samples on the same day).

The samples with catechin presented the highest release in distilled water, as expected in view of this compound's solubility being the highest in water. In contrast, no measurable release from any sample was observed in isooctane (the fatty food simulant). In the present test with oil, the results appear to be related to release of the antioxidant agent into the food. Due to the low solubility of quercetin and catechin in oil, the release rate and protective effect were very limited and were only significant for the samples containing quercetin. These results are in agreement with the higher solubility of quercetin in oil (Nwuha, Nakajima, Tong, \& Ichikawa, 1999; Roedig-Penman \& Gordon, 1998). 


\section{CONCLUSIONS}

Active EVOH films containing catechin or quercetin presented antioxidant activity in solid food and in fatty food products. According to the tests carried out by Pezo's method and through real packaging of fried peanuts, the films act by scavenging radicals in the vapour phase. In the case of sunflower oil, the activity was more limited but still significant and appears to be due to partial release and solubilisation of the agents in the liquid oil. Quercetin showed a double antioxidant/prooxidant rol depending on its concentration and the food substrate. These effects should have to be considered in the final design of packages for specific food products.

\section{ACKNOWLEDGEMENTS}

The authors acknowledge the financial support of the Spanish Ministry of Science and Innovation, projects AGL2006-02176, AGL2009-08776 and FunC-Food CSD2007-00063, and the C. L-d-D fellowship (FPU program). Mary Georgina Hardinge provided assistance with the English language text.

\section{REFERENCES}

Abou Samra, M., Chedea, V. S., Economou, A., Calokerinos, A., \& Kefalas, P. (2011). Antioxidant/prooxidant properties of model phenolic compounds: Part I. Studies on equimolar mixtures by chemiluminescence and cyclic voltammetry. Food Chemistry, 125(2), 622-629.

Aucejo, S., Catala, R., \& Gavara, R. (2000). Interactions between water and EVOH food packaging films. Food Science and Technology International, 6(2), 159-164.

Aucejo, S., Marco, C., \& Gavara, R. (1999). Water effect on the morphology of EVOH copolymers. Journal of Applied Polymer Science, 74(5), 1201-1206.

Boots, A. W., Haenen, G., \& Bast, A. (2008). Health effects of quercetin: From antioxidant to nutraceutical. European Journal of Pharmacology, 585(2-3), 325-337.

Burroni, L. V., Grosso, N. R., \& Guzman, C. A. (1997). Principal volatile components of raw, roasted, and fried Argentinean peanut flavors. Journal of Agricultural and Food Chemistry, 45(8), 3190-3192.

Garces, O., Nerin, C., Beltran, J. A., \& Roncales, P. (2004). Antioxidant active varnish Patent EP1477519,. In. Spain. 
Han, J. H., Hwang, H. M., Min, S., \& Krochta, J. M. (2008). Coating of Peanuts with Edible Whey Protein Film Containing alpha-Tocopherol and Ascorbyl Palmitate. Journal of Food Science, 73(8), E349-E355.

Huang, S. W., Frankel, E. N., \& German, J. B. (1994). Antioxidant activity of alphatocopherols and gamma-tocopherols in bulk oils and in oil-in-water emulsions. Journal of Agricultural and Food Chemistry, 42(10), 2108-2114.

Jung, M. Y., \& Min, D. B. (1990). Effects of alpha-tocopherol, gamma-tocopherol, and delta-tocopherol on oxidative stability of soybean oil. Journal of Food Science, 55(5), 1464-1465.

Konsoula, Z., \& Liakopoulou-Kyriakides, M. (2010). Effect of endogenous antioxidants of sesame seeds and sesame oil to the thermal stability of edible vegetable oils. Lwt-Food Science and Technology, 43(9), 1379-1386.

Lopez-de-Dicastillo, C., Alonso, J. M., Catala, R., Gavara, R., \& Hernandez-Munoz, P. (2010). Improving the Antioxidant Protection of Packaged Food by Incorporating Natural Flavonoids into Ethylene-Vinyl Alcohol Copolymer (EVOH) Films. Journal of Agricultural and Food Chemistry, 58(20), 10958-10964.

Lopez-de-Dicastillo, C., Balasubramanian, A., Yam, K. L., \& Schaich, K. (2009). Characterization of the antioxidant activity of quercetin against lipid oxidation for controlled release packaging. In I. o. F. Technologists" (Ed.), IFT Food Expo. New Orleans, USA.

Lopez-Rubio, A., Almenar, E., Hernandez-Munoz, P., Lagaron, J. M., Catala, R., \& Gavara, R. (2004). Overview of active polymer-based packaging technologies for food applications. Food Reviews International, 20(4), 357-387.

Lopez-Rubio, A., Lagaron, J. M., Gimenez, E., Cava, D., Hernandez-Munoz, P., Yamamoto, T., \& Gavara, R. (2003). Morphological alterations induced by temperature and humidity in ethylene-vinyl alcohol copolymers. Macromolecules, 36(25), 9467-9476.

López-Vilariño, J., Noguerol, C., Villaverde, M., Sabín, J., \& González, M. V. (2006). Addition of natural antioxidants to polyolefins formulations. In Addcon World Cologne (Germany): Rapra Technology.

Martin-Diana, A. B., Rico, D., \& Barry-Ryan, C. (2008). Green tea extract as a natural antioxidant to extend the shelf-life of fresh-cut lettuce. Innovative Food Science \& Emerging Technologies, 9(4), 593-603.

Martin-Polvillo, M., Marquez-Ruiz, G., \& Dobarganes, M. C. (2004). Oxidative stability of sunflower oils differing in unsaturation degree during long-term storage at room temperature. Journal of the American Oil Chemists Society, 81(6), 577-583.

Martínez-Florez, S., González-Gallego, J., Culebras, J. M., \& Muñon, M. J. (2002). Los flavonoides: propiedades y acciones antioxidantes. Nutr.Hosp., XVII (6), 271-278.

Mastromatteo, M., Barbuzzi, G., Conte, A., \& Del Nobile, M. A. (2009). Controlled release of thymol from zein based film. Innovative Food Science \& Emerging Technologies, 10(2), 222-227.

Moore, M. E., Han, I. Y., Acton, J. C., Ogale, A. A., Barmore, C. R., \& Dawson, P. L. (2003). Effects of antioxidants in polyethylene film on fresh beef color. Journal of Food Science, 68(1), 99-104. 
Nerín, C., Tovar, L., Djenane, D., Camo, J., Salafranca, J., Beltran, J. A., \& Roncales, P. (2006). Stabilization of beef meat by a new active packaging containing natural antioxidants. Journal of Agricultural and Food Chemistry, 54(20), 7840-7846.

Nerin, C., Tovar, L., \& Salafranca, J. (2008). Behaviour of a new antioxidant active film versus oxidizable model compounds. Journal of Food Engineering, 84(2), 313-320.

Nwuha, V., Nakajima, M., Tong, J. H., \& Ichikawa, S. (1999). Solubility study of green tea extracts in pure solvents and edible oils. Journal of Food Engineering, 40(3), 161-165.

Pastorelli, S., Valzacchi, S., Rodriguez, A., \& Simoneau, C. (2006). Solid-phase microextraction method for the determination of hexanal in hazelnuts as an indicator of the interaction of active packaging materials with food aroma compounds. Food Additives and Contaminants, 23(11), 1236-1241.

Pedrielli, P., Pedulli, G. F., \& Skibsted, L. H. (2001). Antioxidant mechanism of flavonoids. Solvent effect on rate constant for chain-breaking reaction of quercetin and epicatechin in autoxidation of methyl linoleate. Journal of Agricultural and Food Chemistry, 49(6), 3034-3040.

Pekkarinen, S. S., Heinonen, I. M., \& Hopia, A. I. (1999). Flavonoids quercetin, myricetin, kaemferol and (+)-catechin as antioxidants in methyl linoleate. Journal of the Science of Food and Agriculture, 79(4), 499-506.

Pezo, D., Salafranca, J., \& Nerin, C. (2006). Design of a method for generation of gasphase hydroxyl radicals, and use of HPLC with fluorescence detection to assess the antioxidant capacity of natural essential oils. Analytical and Bioanalytical Chemistry, 385(7), 1241-1246.

Pezo, D., Salafranca, J., \& Nerin, C. (2008). Determination of the antioxidant capacity of active food packagings by in situ gas-phase hydroxyl radical generation and highperformance liquid chromatography-fluorescence detection. Journal of Chromatography A, 1178(1-2), 126-133.

Roedig-Penman, A., \& Gordon, M. H. (1998). Antioxidant properties of myricetin and quercetin in oil and emulsions. Journal of the American Oil Chemists Society, 75(2), 169-180.

Rooney, M. L. (1995). Active Food Packaging. In B. A. Profesional (Ed.), Chapman \& Hall. Londres (Gran Bretaña).

Saran, M., \& Summer, K. H. (1999). Assaying for hydroxyl radicals: Hydroxylated terephthalate is a superior fluorescence marker than hydroxylated benzoate. Free Radical Research, 31(5), 429-436.

Viuda-Martos, M., Ruiz-Navajas, Y., Fernandez-Lopez, J., \& Perez-Alvarez, J. A. (2009). Effect of adding citrus waste water, thyme and oregano essential oil on the chemical, physical and sensory characteristics of a bologna sausage. Innovative Food Science \& Emerging Technologies, 10(4), 655-660.

Wambura, P., \& Yang, W. W. (2010). Ultrasonication and Edible Coating Effects on Lipid Oxidation of Roasted Peanuts. Food and Bioprocess Technology, 3(4), 620628. 
Williams, J. P., Duncan, S. E., Williams, R. C., Mallikarjunan, K., Eigel, W. N., \& O'Keefe, S. F. (2006). Flavor fade in peanuts during short-term storage. Journal of Food Science, 71(3), S265-S269.

Yanishlieva, N. V., Marinova, E. M., Gordon, M. H., \& Raneva, V. G. (1999). Antioxidant activity and mechanism of action of thymol and carvacrol in two lipid systems. Food Chemistry, 64(1), 59-66.

Zuta, P. C., Simpson, B. K., Zhao, X., \& Leclerc, L. (2007). The effect of alphatocopherol on the oxidation of mackerel oil. Food Chemistry, 100(2), 800-807. 


\title{
Artículo 3
}

\section{DEVELOPMENT OF A NEW ANTIOXIDANT ACTIVE \\ PACKAGING FILMS BASED ON EVOH AND GREEN TEA EXTRACT}

\author{
Carol López de Dicastillo, Cristina Nerín, Pilar Alfaro, Ramón Catalá, \\ Rafael Gavara and Pilar Hernández-Muñoz
}

Submitted to Journal of Agricultural and Food Chemistry 


\section{ABSTRACT}

Ethylene vinyl alcohol copolymer (EVOH) films containing green tea extract were successfully produced by extrusion. The films were brown and translucent and the addition of the extract did not greatly modify the water and oxygen permeability, $T_{g}$, or crystallinity of the films but improved their thermal resistance. An analysis by HPLC revealed that the antioxidant components of the extract suffered partial degradation during extrusion, reducing the content of catechin gallates and increasing the concentration of free gallic acid. Exposure of the films to various food simulants showed that the liquid simulants increased their capacity to reduce DPPH• and ABTS•+ radicals. The release of green tea extract components into the simulant monitored by HPLC showed that all compounds present in the green tea extract were partially released, although the extent and kinetics of release were dependent on the type of food. In aqueous food simulants, gallic acid was the main antioxidant component released. In 95\% ethanol (fatty food simulant) a substantial contribution of catechins greatly increased antioxidant efficiency. Kinetically, gallic acid was released faster than catechins, owing to its faster diffusivity in the polymer matrix as a consequence of its smaller molecular size.

Keywords: active packaging, antioxidant, release, $\mathrm{EVOH}$, green tea extract vinyl alcohol copolymer (EVOH) 


\section{INTRODUCTION}

To reduce oxidation in sensitive food products, the addition of antioxidants and the design of a suitable vacuum or modified atmosphere packaging technology are the two most common alternatives. A novel alternative that is being developed is the design of active antioxidant packaging systems (Nerín, 2010). Various antioxidant agents were added to polymeric films with the purpose of being delivered to oxygen-sensitive food, improving its chemical stability. Substances such as carvacrol, aromatic plant extract (oregano, barley), or $\alpha$ tocopherol have been incorporated into polymers for the preparation of active packages (Bentayeb et al., 2007; Granda-Restrepo et al., 2009; Nerín, 2010; Nerín et al., 2006; Peltzer et al., 2009; Pereira de Abreu et al., 2010; Pezo et al., 2008; Tovar et al., 2005). Although all these developments presented significant antioxidant activity they have some drawbacks, derived from a collateral effect on sensory properties of food owing to the release of highly aromatic substances, or the absence of a triggering mechanism. Flavonoids, catechin, and quercetin have also been incorporated into polymers to reduce polymer degradation (Dopico-Garcia et al., 2011) and/or to reduce food oxidation (Lopez-de-Dicastillo et al., 2010a). These substances are well-known antioxidant agents and do not add relevant modification of food flavor; however, although naturally present in many food products, they are not food additives and therefore these agents should receive the status of food additive before commercialization of the active package.

Green tea extract is a great source of flavonoids with the status of food additive. These compounds have aroused considerable interest recently because of their potential beneficial effects on human health. They have been reported to have antiviral, anti-allergic, antiplatelet, anti-inflammatory, antitumor, and antioxidant activities (Graham, 1992; Lambert et al., 2010; Pedrielli et al., 2001; Rietveld and Wiseman, 2003). The main compounds responsible for this antioxidant activity are gallic acid and eight major catechins: (+)-catechin (C), (-)-epicatechin (EC), (-)-catechin gallate (CG), ()-epicatechin gallate (ECG), (-)-gallocatechin (GC), (-)-epigallocatechin 
(EGC), (-)-gallocatechin gallate (GCG), and (-)-epigallocatechin gallate (EGCG) (Lin et al., 2008; Poon, 1998; Saito et al., 2007; Zeeb et al., 2000; Zuo et al., 2002).

Tea catechins can act as antioxidants by donation of hydrogen atoms, as acceptors of free radicals, interrupters of chain oxidation reactions, or by chelating metals (Gramza and Korczak, 2004). It has also been shown that green tea extract has greater antioxidant activity than a reproduced mixture of catechins, a well-known synergistic effect (Cuvelier et al., 2000; Korczak et al., 1998). Possible interactions must be considered, and not only the content of phenolic components

Green tea extract has been already incorporated in food in order to extend its shelf life resulting in food protection and no visible color or perceivable odor change in treated samples when the extract was incorporated at optimum concentrations (Gramza-Michalowska and Regula, 2007; Martin-Diana et al., 2008; Wanasundara and Shahidi, 1998).

Green tea (GT) extract has also been investigated as a potential source of antioxidants to be used as plastic additives to protect them during polymer processing/manufacturing. The performance of polypropylene samples stabilized with GT at $0.05 \%(\mathrm{w} / \mathrm{w})$ was developed by Dopico-Garcia et al. (2010). Results showed GT can be an interesting source of antioxidants for plastics because the stability provided by the addition of GT was comparable to the stability provided by synthetic additives (Dopico-Garcia et al., 2011).

The purpose of this work was to develop an antioxidant active packaging material to improve food protection by the incorporation of green tea extract in a hydrophilic plastic layer, EVOH 44, by flat extrusion. The material developed was characterized by the analysis of: i) its optical, thermal, and barrier properties, ii) its antioxidant efficiency, and iii) the release kinetics of the antioxidant agents in several food simulants. 


\section{MATERIALS AND METHODS}

\subsection{Chemicals and Reagents}

An ethylene vinyl alcohol copolymer with a 44\% ethylene molar content (EVOH) was kindly supplied by The Nippon Synthetic Chemical Company, (Osaka, Japan). Green tea extract was supplied by Plantextrakt (The nature network), Baceiredo S.L. (Vitoria, Spain). Reagent-grade absolute ethanol, methanol, formic acid, 2,2-diphenyl-1-picrylhydrazyl 95\% free radical, 2,2'azino-bis(3-ethylbenzothiazoline-6-sulfonic acid), and acetic acid were purchased from Sigma (Madrid, Spain). Gallic acid, caffeine, catechin hydrate, and epigallocatechin gallate were purchased from Fluka Biochemika (Barcelona, Spain). Water was obtained from a Milli-Q Plus purification system (Millipore, Molsheim, France).

\subsection{Film Preparation}

EVOH films containing green tea extract were obtained by flat extrusion. The extract was incorporated at $5 \%(\mathrm{w} / \mathrm{w})$ concentration into hydrophilic $\mathrm{EVOH}$, and the antioxidant-EVOH mixture was extruded on a Brabender DSE 20/40 co-rotating twin-screw extruder (Plastograph, Düsseldorf, Germany) at $200{ }^{\circ} \mathrm{C}$ at a screw speed of $100 \mathrm{rpm}$. The resulting films were approximately 35 microns thick, although the thickness of every sample was individually measured before tests using a digital Mitutoyo micrometer (Metrotec, San Sebastian, Spain). The film samples obtained were vacuum packaged in aluminum/LDPE bags and stored at room temperature until the moment of analysis.

\subsection{Antioxidant activity of GT and film of EVOH with GT incorporated}

Antioxidant activities of GT and film containing GT were measured by two different antioxidant assays, $\mathrm{DPPH}^{\circ}$ method and $\mathrm{ABTS}^{\circ+}$ assay, that measure antioxidant effectiveness by monitoring the inhibition of oxidation of a suitable substrate. The $\mathrm{DPPH}^{\circ}$ method is based on the bleaching rate of a stable free radical, 2,2-diphenyl-1-picrylhydrazyl ( $\left.\mathrm{DPPH}^{\circ}\right)$, monitored at a characteristic 
wavelength in the presence of the sample. In its radical form $\mathrm{DPPH}^{\circ}$ absorbs at $517 \mathrm{~nm}$, but upon reduction by an antioxidant or a radical compound its absorption decreases (Okada and Okada, 1998). The ABTS ${ }^{\circ+}$ assay is based on the inhibition by antioxidants of the radical cation 2,2-azinobis-(3ethylbenzothiazoline-6-sulfonate), $\mathrm{ABTS}^{\circ+}$, which has a characteristic longwavelength absorption spectrum showing main absorption maxima at $415 \mathrm{~nm}$ (Sanchez-Moreno, 2002). These two indicator radicals are neutralized either by direct reduction via electron transfers or by radical quenching via $\mathrm{H}$ atom transfer (Prior et al., 2005). In both assays, the percentage inhibition values were calculated using this equation:

In order to standardize the results, scavenging activities of the $\mathrm{DPPH}^{\circ}$ and $\mathrm{ABTS}^{\circ+}$ radicals were expressed as ascorbic acid concentration, using a calibrated curve of ascorbic acid concentration vs. I (\%).

The antioxidant activities of the extract and the film were determined by these methods in order to study the degree of immobilization of the antioxidant in the film and its final active concentration in the film after undergoing the process of flat extrusion. Film extraction was performed by two consecutive extractions in ethanol at $65^{\circ} \mathrm{C}$ for 3 hours. The antioxidant activity was determined by the $\mathrm{DPPH} \cdot$ method. Similarly, extraction was done under water, and the antioxidant activity was measured by the ABTS $\bullet+$ assay.

\subsection{Chromatographic study of GT and film of EVOH with GT incorporated}

Green tea extract and the ethanolic extraction of the film (described in the previous section) were analyzed by HPLC with UV detector in order to identify their major compounds. A first identification of the compounds was performed by UPLC-q-TOF using an Acquity BEH C18 (100 mm X 2.1) column with 1.7 $\mu \mathrm{m}$ particle size. The mobile phase consisted of $\mathrm{A}$ : MilliQ water and $\mathrm{B}$ : methanol with $0.1 \%$ formic acid. Solvent flow was $0.3 \mathrm{~mL} / \mathrm{min}$ with a linear 
gradient from $5 \%$ to $95 \%$ of B. The detection system was a q-TOF equipped with an electrospray source in positive mode, with the mass range $\mathrm{m} / \mathrm{z}$ between 50 and 5000 , the capillary voltage $1 \mathrm{kV}$, and source and desolvation temperatures 100 and $400{ }^{\circ} \mathrm{C}$, respectively. The cone and desolvation flows were 20 and $600 \mathrm{~L} / \mathrm{h}$ of nitrogen, respectively. The analysis was performed on an Agilent Technologies 1200 Series equipped with an SPD-M10Avp diode array detector, a DGU-14A degasser, an SCL-10Avp system controller and Class-VP v.6.14 chromatography data system. A stainless steel column, Gemini C6-Phenyl 110A, $4.6 \times 150 \mathrm{~mm}, 5 \mu \mathrm{m}$ particle size, protected by an RP_18 pre-column, both from Phenomenex (Torrance, CA, USA), was used. The flow rate was $1 \mathrm{~mL} / \mathrm{min}$ and the injection volume was $20 \mu \mathrm{L}$. The mobile phases were $0.3 \%$ formic acid (solvent $A$ ) and methanol $0.3 \%$ formic acid (solvent B). The gradient started with $12 \%$ solvent B, changing linearly to $40 \%$ solvent B over a period of $25 \mathrm{~min}$, then changing linearly to $60 \%$ until min 60 was reached, and then changing to $100 \%$ over a period of $1 \mathrm{~min}$. This was maintained for $5 \mathrm{~min}$, followed by a change to $12 \%$ solvent B for $10 \mathrm{~min}$. Peaks were detected by measurement of UV- absorbance at $280 \mathrm{~nm}$. A tentative identification was performed by comparison of the chromatograms with those reported in the literature and the results of the UPLC-q-TOF chromatography. Catechin, caffeine, gallic acid, and EGCG were identified by injection of standards.

\subsection{Optical properties}

The film color was determined with a Konica Minolta CM-3500d spectrophotometer set to D65 illuminant $/ 10^{\circ}$ observer. The film specimen was placed on the surface of a standard white plate, and the CIELAB color space was used to determine the parameters $L^{*}, a^{*}$, and $b^{*}$. The color was also expressed using the polar coordinates $L^{*}, C^{*}$, and $h_{a b}$, where $L^{*}$ is the same as previously, $C^{*}$ is the chroma or saturation index, and $h_{a b}$ is the angle. Eight measurements were taken of each sample, and three samples of each film 
were measured. All of the samples were selected with a thickness of $35 \mu \mathrm{m}$ to reduce the effect of thickness on color measurements.

\subsection{Thermal Analysis}

Thermogravimetric analyses were carried out using a Mettler Toledo TGA/SDTA/851 thermal analyzer (Columbus, OH, USA). The samples were heated from room temperature to $900^{\circ} \mathrm{C}$ under a nitrogen atmosphere in order to determine any evaporation of volatile compounds, as well as the degradation temperatures of the antioxidant-containing materials.

The thermal properties of the samples were also determined with a Model Q2000 DSC from TA Instruments (New Castle, DE, USA). Thermograms were obtained from $25^{\circ} \mathrm{C}$ to $220^{\circ} \mathrm{C}$ with $10^{\circ} \mathrm{C} /$ min heating, cooling to $25^{\circ} \mathrm{C}$, and a second heating process to $220^{\circ} \mathrm{C}$. The glass transition $\left(T_{g}\right)$ and melting point $\left(T_{m}\right)$ temperatures and the enthalpy $\left(\Delta \mathrm{H}_{\mathrm{m}}\right)$ were calculated. Considering the polymer percentage of each sample, a corrected enthalpy $\left(\Delta \mathrm{H}_{\text {mcor }}\right)$ value was also estimated.

\subsection{Barrier properties}

\subsubsection{Water vapor permeability}

WVP tests were carried out at 50\%, 75\% and $100 \% \mathrm{RH}$ and $23{ }^{\circ} \mathrm{C}$ using permeability cups (Elcometer, Manchester, England) in accordance with ISO 2528. The aluminum cups were filled with $7 \mathrm{~g}$ of silica gel and sealed with vacuum silicon grease (Sigma, Barcelona, Spain) and the film to be tested. The film was fixed in place with a flat Viton ring, an aluminum ring and three press-screws. To assure the necessary relative humidity, the cups were then stored in desiccators containing salt solutions: magnesium nitrate $\mathrm{Mg}\left(\mathrm{NO}_{3}\right)_{2} \cdot 6 \mathrm{H}_{2} \mathrm{O}$, sodium chloride $\mathrm{NaCl}$ and water for $50 \%, 75 \%$ and $100 \% \mathrm{RH}$, respectively. The cups were weighed daily, and the plot of the weight increment vs. time provided the water vapor transmission rate. These values were then divided by the water pressure gradient and multiplied by the sample thickness to obtain the water vapor permeability value. 


\subsubsection{Oxygen permeability}

The oxygen permeation rates of the materials were determined at $50 \%$ and $90 \% \mathrm{RH}$ and $23{ }^{\circ} \mathrm{C}$ using an OXTRAN Model 2/21 ML Mocon (Lippke, Neuwied, Germany). After conditioning the samples in the OXTRAN cells for 6 hours, the transmission values were determined every $45 \mathrm{~min}$ until constant. After the permeation tests were completed, continuous permeation experiments were carried out on each sample to determine the diffusion coefficient $(D)$. From the transmission rate values measured during the transient state, the value of $D$ was assessed from the solution to Fick's second law for the boundary conditions of an isostatic permeation experiment (Gavara and Hernández, 1993).

\subsection{Release studies}

A study of the release of the active compounds from the films was carried out by determining the specific migration from the polymer into the various food simulants specified in European law: water was used as aqueous food simulant, 3\% acetic acid acidic food simulant, 10\% ethanol as alcoholic food simulant, and $95 \%$ ethanol as fatty food simulant. Migration studies were conducted at $40 \pm 1^{\circ} \mathrm{C}$, in accordance with EU regulations (UNE-EN 1186-3). Double-sided, total immersion migration tests were performed as follows: 80 $\mathrm{cm}^{2}$ of each plastic sample and $100 \mathrm{~mL}$ of the simulant (area-to-volume ratio around $\left.6 \mathrm{dm}^{2} / L\right)$ were placed in tubes $(12.5 \mathrm{~cm}$ high $\times 4.3 \mathrm{~cm}$ diameter) covered with aluminum foil to protect the content from light. Simulants were deoxygenated by bubbling nitrogen, and a final nitrogen flush was done before closing the cells to reduce the oxygen percentage in the cell headspace. Periodically, three vials were opened and the antioxidant activity provided by the films was evaluated by measuring the radical scavenging ability of the food simulants, using the $\mathrm{ABTS}^{\circ+}$ assay in the case of aqueous simulants, and the 
$\mathrm{DPPH}^{\circ}$ method in the case of the $95 \%$ ethanol simulant. Both assays are described in section 2.3.

At the same time, the release of the various green tea components was analyzed by HPLC. Simulants were previously concentrated by evaporation using a water bath at $60^{\circ} \mathrm{C}$ and flushing with nitrogen gas. The resulting dry residues were redissolved on mobile phase solvents, filtered, and analyzed by HPLC. The conditions are described in section 2.4.

\subsection{Statistical analysis}

One-way analyses of variance were carried out. The SPSS $^{\circledR}$ computer program (SPSS Inc., Chicago, IL, USA) was used. Differences in pairs of mean values were evaluated by the Tukey-b test for a confidence interval of $95 \%$. Data are represented as mean \pm standard deviation.

\section{RESULTS AND DISCUSSION}

In this work, EVOH films containing green tea extract at $5 \%(\mathrm{w} / \mathrm{w})$ as antioxidant agent were successfully produced by flat extrusion. The films were flexible, with a thickness of approximately $35 \mu \mathrm{m}$, transparent, and without discontinuities.

\subsection{Antioxidant activity and composition}

First, the antioxidant activity (AA) of green tea extract was determined by the $\mathrm{DPPH}^{\circ}$ and $\mathrm{ABTS}^{\circ+}$ methods. $1 \mathrm{~g}$ of green tea extract dissolved in ethanol presented an AA versus the $\mathrm{DPPH}^{\circ}$ radical equivalent to $7.43 \mathrm{~g}$ of ascorbic acid. The AA versus $\mathrm{ABTS}^{\circ+}$ of $1 \mathrm{~g}$ of the extract dissolved in water was equivalent to $3.80 \mathrm{~g}$ of ascorbic acid. These results confirm the high antioxidant activity of the extract, especially in ethanol. Differences in the measurement of the AA with these two radicals have often been reported. Besides the use of different solvent media in the two methods, reactivity patterns and mechanisms are difficult to interpret without detailed information about the composition and structures of the antioxidants tested. Both assays 
are usually classified as SET reactions (single electron transfer), but these two indicator radicals may in fact be neutralized either by direct reduction via electron transfers or by radical quenching via $\mathrm{H}$ atom transfer (Dudonne et al., 2009; Prior et al., 2005; Zhu et al., 2011).

To determine the real concentration of green tea extract in the polymeric film, extractions with water and ethanol were conducted at $65^{\circ} \mathrm{C}$. To check for any degradation effect of the extraction process, an aqueous solution of green tea extract underwent the extraction process. The extract suffered a large degradation, with the $A A$ decreasing to $20.4 \%$ of the initial value. When the film was submitted to the extraction process, the aqueous extract presented an equivalent activity of $4.33 \cdot 10^{-3} \mathrm{~g}$ of ascorbic acid per gram of film versus the $\mathrm{ABTS}^{\circ+}$ radical (nominal value was 0.0795 ). According to this result, only $5.5 \%$ of the nominal extract maintained AA after processing and extraction.

The same procedure was followed with ethanol as solvent. An ethanolic solution of the extract was maintained for 3 hours at $65^{\circ} \mathrm{C}$ and then analyzed by the DPPH method. The green tea extract maintained $88.3 \%$ of the nominal activity. Next, the ethanol extraction of the film presented an equivalent activity of $0.264 \mathrm{~g}$ of ascorbic acid per gram of film versus the DPPH radical (nominal value was $0.371 \mathrm{~g}$ ), $71 \%$ of the nominal activity. According to these results, the extrusion process resulted in a degradation of the extract of about $20 \%$, as the evaluation of the ethanolic extract suggests, possibly due to the potential polymerization of phenols and the degradation of some catechins. The AA of green tea is greatly deteriorated when heated in water, this extraction procedure being unsuitable.

Green tea extract and the ethanolic extraction of the film were also studied by HPLC in order to analyze their major compounds. UPLC-qTOF chromatography allowed the identification in the tea extract of gallic acid, caffeine, catechin, gallocatechin, and gallocatechin gallate through the molecular ions, although isomers could not be distinguished. Figure 3.1 shows the chromatograms obtained by HPLC-UV for both the green tea extract and the film. The original green tea extract consisted of several compounds, eight 
of them identified as gallic acid (GA), epigallocatechin (EGC), catechin (C), caffeine (CF), epigallocatechin gallate (EGCG), gallocatechin gallate (GCG), epicatechin gallate (ECG), and catechin gallate (CG) by comparison with other reports in the literature.

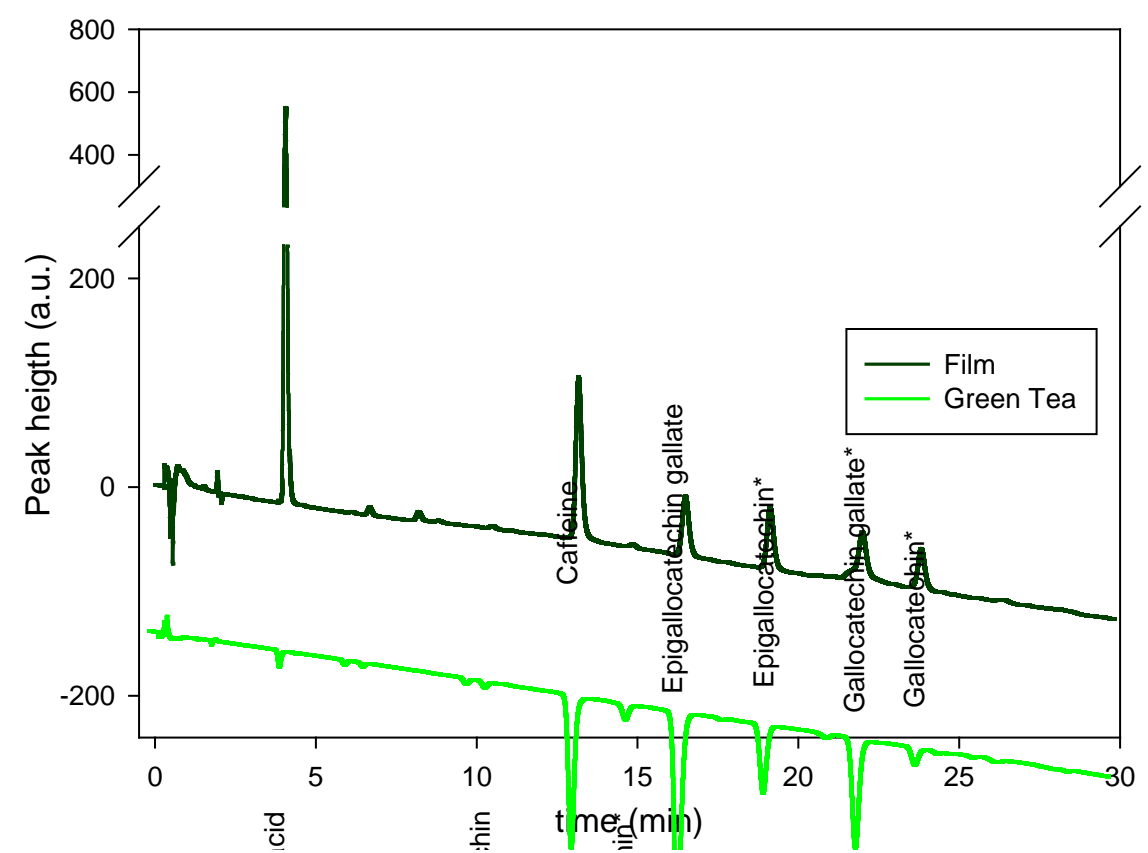

Figure 3.1. Chromatogram of GT extract (Green tea) and the resulting ethanolic extraction from EVOH_GT5\% (film). *, tentative identification.

The resulting ethanolic extractions of the film were also analyzed by HPLC with UV detection. Chromatograms revealed that the extract incorporated was affected by thermal and mechanical stresses during the extrusion process, implying changes in the concentration of some compounds. Several tea catechin concentrations decreased considerably, especially the four catechin gallates. Apparently, the ester bond of the gallate breaks during film manufacture, resulting in a severe increase of gallic acid concentration in the film. 


\subsection{Optical properties}

The films containing the extract were transparent and brown and clearly different from the blank samples. Color parameters of the extruded EVOH films were analyzed, and the results are given in Table 3.1. The incorporation of the green tea extract slightly reduced the luminosity of the film, as the $\mathrm{L}$ values show. The brownish color of the films developed is reflected by the rise in the $a^{*}$ and $b^{*}$ values, and the hue angle values falling in the second portion of the first quadrant. This film color change may be a consequence of sugar caramelization during the extrusion process, since the extract contains sugars, free or as glycosilated catechins that can undergo caramelization reactions. Partial polymerization of phenols during heating may also be involved in the development of the brown color.

Table 3.1. Color Parameters of EVOH-based materials: control film (blank) and film containing $5 \%$ of green tea extract (EVOH GT5\%).

\begin{tabular}{lccccc}
\hline & $L^{*}$ & $\mathrm{a}^{*}$ & $\mathrm{~b}^{*}$ & $\mathrm{C}^{*}$ & $\mathrm{~h}_{\mathrm{ab}}$ \\
\hline Blank & $91.1 \pm 1.4 \mathrm{~b}$ & $-0.08 \pm 0.02 \mathrm{a}$ & $-0.05 \pm 0.02 \mathrm{a}$ & $0.10 \pm 0.03 \mathrm{a}$ & $209.3 \pm 5.9 \mathrm{a}$ \\
& & & & & \\
EVOH GT5\% & $81.1 \pm 1.3 \mathrm{a}$ & $6.3 \pm 0.3 \mathrm{~b}$ & $12.8 \pm 0.6 \mathrm{~b}$ & $14.2 \pm 0.7 \mathrm{~b}$ & $63.9 \pm 0.3 \mathrm{~b}$ \\
\hline
\end{tabular}

$a, b$ indicate significant differences among the values of the same color property.

\subsection{Thermal characterization}

Thermal analyses of the films were carried out to study the influence of the addition of the green tea extract on the thermal stability and morphology of the polymer. As Figure 3.2 shows, in the thermogram of the green tea extract there is a broad degradation band that starts at $150^{\circ} \mathrm{C}$, with a maximum at approximately $200{ }^{\circ} \mathrm{C}$. The catechins from the extract are partially glycosylated, and a "caramelization" of these sugars takes place, probably due to heating. A partial degradation of the catechins, leading to the formation of gallic acid, and the polymerization of phenols might be related to this transition too. The degradation continues over a wide temperature range, with a final ash content of ca. $50 \%$ of the initial weight. 
TGA of the two polymeric samples showed that the degradation occurred in a main step at a temperature above $400{ }^{\circ} \mathrm{C}$. The $\mathrm{EVOH}$ blank sample presented its maximum loss rate at $414{ }^{\circ} \mathrm{C}$. The film containing the green tea extract had improved thermal stability, the center of the transition being at $463{ }^{\circ} \mathrm{C}$ maximum. The presence of the antioxidant mixture in the matrix is probably responsible for this stability, and this is in agreement with the results observed in $\mathrm{EVOH}$ materials containing catechin or quercetin (Lopez-de-Dicastillo et al., 2010a).

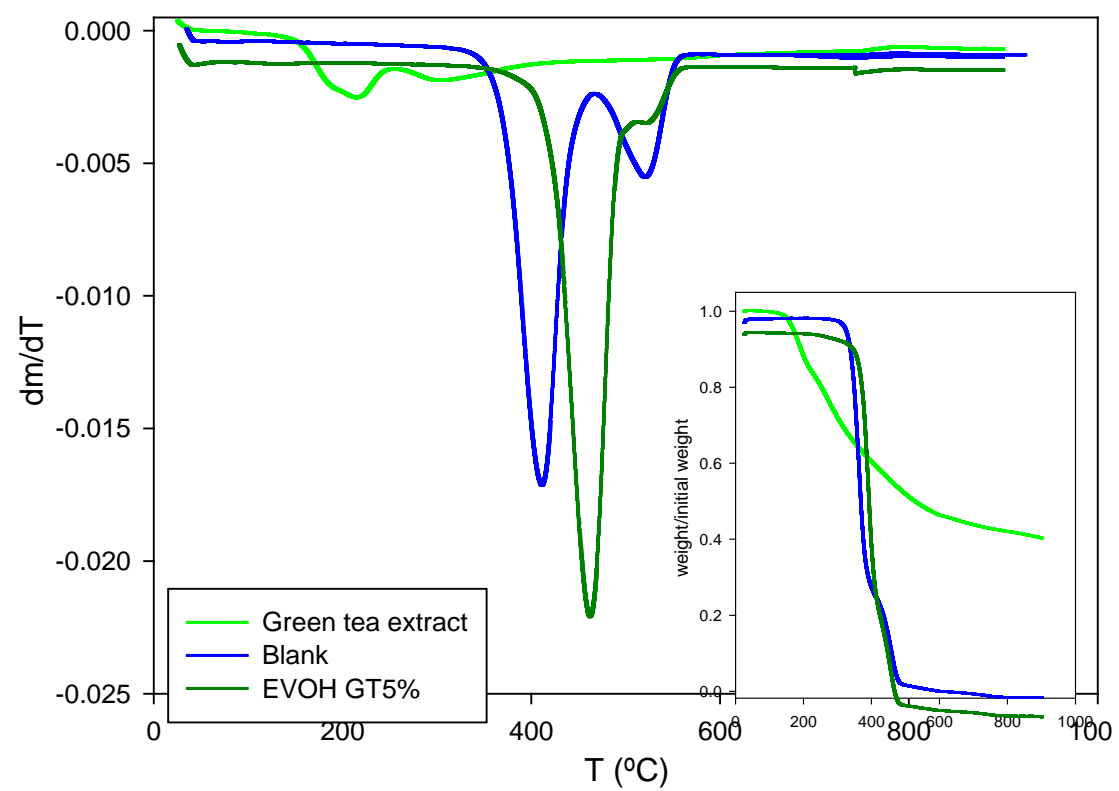

Figure 3.2. Weight loss and derivative of the weight loss of green tea extract and EVOH materials.

Materials were also analyzed by DSC, to study the effect of the extract addition on the polymer morphology. Table 3.2 summarizes the main information obtained from the DSC analysis. As can be seen, the glass transition temperature increased significantly in the EVOH-GT sample, indicating increased rigidity with respect to the blank sample. Also, the presence of green tea extract modified the crystallinity of the composite material. The thermogram showed a decrease in the melting point (minimum 
of the endotherm) and an increase in the melting enthalpy. These two observations can be interpreted as if the additive produces a nucleating effect on the polymer, increasing the crystalline percentage of the polymer although the crystal structure is more deficient. Similar properties were observed in $\mathrm{EVOH}$ films containing catechin and quercetin, although the effects of these two flavonoids on the thermal behavior of $\mathrm{EVOH}$ were not as significant (Lopez-de-Dicastillo et al., 2010a).

Table 3.2. Thermal properties obtained from DSC thermograms during the first heating for the $\mathrm{EVOH}$-based materials: control film (blank) and film containing $5 \%$ of green tea extract (EVOH GT5\%).

\begin{tabular}{ccccc}
\hline Sample & $\mathrm{T}_{\mathrm{g}}\left({ }^{\circ} \mathrm{C}\right)$ & $\mathrm{T}_{\mathrm{m}}\left({ }^{\circ} \mathrm{C}\right)$ & $\Delta \mathrm{H}_{\mathrm{m}}(\mathrm{J} / \mathrm{g})$ & $\Delta \mathrm{H}_{\mathrm{m}, \text { cor }}(\mathrm{J} / \mathrm{g})$ \\
\hline Blank & $43.0 \pm 1.3 \mathrm{a}$ & $167.0 \pm 0.3 \mathrm{~b}$ & $-74.8 \pm 1.8 \mathrm{a}$ & $-74.8 \pm 1.8 \mathrm{a}$ \\
EVOH GT5\% & $49.4 \pm 1.7 \mathrm{~b}$ & $163.4 \pm 2.6 \mathrm{a}$ & $-84.3 \pm 5.4 \mathrm{~b}$ & $-88.5 \pm 5.4 \mathrm{~b}$
\end{tabular}

$\mathrm{a}, \mathrm{b}$ indicate significant differences among the values of the same thermal property.

\subsection{Barrier Properties}

\subsubsection{Water vapor permeability}

As Table 3.3 shows, WVP was measured at 50,75 , and $100 \%$ RH gradients at $23{ }^{\circ} \mathrm{C}$. Both samples presented the same profile: permeability increased significantly with the $\mathrm{RH}$ gradient (statistics not shown), showing the plasticizing effect of water on the polymer matrix at high humidities. In dry conditions, EVOH is well known for its good barrier properties, owing to strong interchain interactions among EVOH hydroxyl groups that result in high cohesive energy and low chain flexibility. But, as the humidity increases, water molecules get sorbed and interact with the polymer chains, reducing intermolecular interactions and increasing flexibility, and as a consequence the molecular diffusion is accelerated. This effect is in agreement with several studies in which water permeability increased considerably in very humid conditions (Aucejo et al., 2000; Lopez-de-Dicastillo et al., 2010b). 
The addition of the green tea extract to EVOH improved barrier properties at low and medium relative humidities, decreasing up to $50 \%$ with respect to the blank sample, in agreement with thermal analysis that showed a more crystalline morphology for antioxidant-incorporated samples. Nevertheless, the films appeared to be more water sensitive than the pure polymer since at $100 \% \mathrm{RH}$ the water permeability values of the material developed with the active agent were higher than those of the blank sample, probably owing to the higher water affinity of the extract components. This effect was also shown in a previous work (Lopez-de-Dicastillo et al., 2010a).

Table 3.3. Water Vapor and Oxygen Permeability Values for the EVOH-based materials: control film (blank) and film containing 5\% of green tea extract (EVOH GT5\%).

\begin{tabular}{lccccc}
\hline & \multicolumn{2}{c}{ Water vapor permeability } & \multicolumn{2}{c}{ Oxygen permeability } \\
& \multicolumn{2}{c}{$10^{16} \cdot\left(\mathrm{Kg} \cdot \mathrm{m} /\left[\mathrm{m}^{2} \cdot \mathrm{s} \cdot \mathrm{Pa}\right]\right)$} & $10^{21} \cdot\left(\mathrm{m}^{3} \cdot \mathrm{m} /\left[\mathrm{m}^{2} \cdot \mathrm{s} \cdot \mathrm{Pa}\right]\right)$ \\
\hline Sample & $\mathrm{RH} 50$ & $\mathrm{RH} \mathrm{75}$ & $\mathrm{RH} 100$ & $\mathrm{RH} 50$ & $\mathrm{RH} 90$ \\
\hline \hline Blank & $2.0 \pm 0.1 \mathrm{~b}$ & $8.9 \pm 0.6 \mathrm{~b}$ & $13.9 \pm 1.0 \mathrm{a}$ & $7.2 \pm 0.2 \mathrm{~b}$ & $33.6 \pm 0.9 \mathrm{a}$ \\
EVOH GT5\% & $1.16 \pm 0.06 \mathrm{a}$ & $2.45 \pm 0.07 \mathrm{a}$ & $17.3 \pm 1.0 \mathrm{~b}$ & $3.5 \pm 0.3 \mathrm{a}$ & $43.8 \pm 0.5 \mathrm{~b}$
\end{tabular}

$a, b$ indicate significant differences among the values of permeability at the same $\mathrm{RH}$.

The high plasticization of the polymer may increase the areas suitable for transport, including amorphous areas within small and defective crystal structures, where transport is impeded at low humidities.

\subsubsection{Oxygen permeability}

Oxygen transmission through $\mathrm{EVOH}$ is limited by the semicrystalline structure and the high intermolecular and intramolecular cohesive energy. Accordingly, EVOH films have a very low oxygen permeability in the $10^{-21} \cdot \mathrm{m}^{3} \cdot \mathrm{m} /\left(\mathrm{m}^{2} . \mathrm{s} . \mathrm{Pa}\right)$ range. However, EVOH is hygroscopic and absorbs water at high relative humidity, and then loses much of its oxygen barrier performance. Water molecules interact with the hydroxyl groups in the polymer matrix, weakening the existing hydrogen interchain bonds, increasing polymer segment mobility, and facilitating the diffusion of oxygen. As Table 3.3 shows, the permeability to 
oxygen presented a similar profile to permeability to water vapor. $P$ values increased significantly with $\mathrm{RH}$ for both samples, in agreement with previous reports (Aucejo et al., 2000; Yamamoto et al., 2009). The incorporation of the extract improved the oxygen barrier at low humidity, an effect that can be attributed to the previously commented increase in polymer crystallinity. At high humidity, the active film presented higher values than the blank polymer as a result of increased water sensitivity, in agreement with the effect observed in the water permeability.

The diffusion coefficient was also calculated by applying the analytical solution to Fick's law for the boundary conditions of an isostatic permeation process (Gavara and Hernández, 1993). The diffusion coefficient was measured at $90 \% \mathrm{RH}$, and the values were $1.125 \cdot 10^{-13} \mathrm{~m}^{2} / \mathrm{s}$ and $1.63 \cdot 10^{-13} \mathrm{~m}^{2} / \mathrm{s}$ for the EVOH blank and EVOH_GT5\% films, respectively. The values obtained were very similar to the value obtained from the literature, $1 \cdot 10^{-13} \mathrm{~m}^{2} / \mathrm{s}$ (Aucejo et al., 2000). The higher value obtained for the sample containing the extract revealed a faster diffusivity of oxygen in this film as a consequence of a more plasticized polymer structure.

\subsection{Green tea extract release}

Release studies were carried out by exposure of the films developed to the food simulants included in EU regulations (UNE-EN 1186-3) for migration studies. The antioxidant activity of the GT released on food simulants was evaluated periodically by measuring the radical scavenging ability, using the $\mathrm{ABTS}^{\circ+}$ assay in the case of aqueous simulants and the $\mathrm{DPPH}^{\circ}$ method in the case of $95 \%$ ethanol.

Figure 3.3 presents the antioxidant activity of food simulants exposed to GTcontaining films, expressed as equivalent ascorbic acid concentration. The kinetics presented a similar profile with all of the simulants, following an "exponential growth to a maximum" type profile. The effect of the type of food was clearly noticeable, presenting around ten times higher antioxidant activity on $95 \%$ ethanol, probably owing to the better solubility of the active agents in 
this liquid. Catechins, the most powerful antioxidants present in green tea extract, are slightly soluble in water and highly soluble in ethanol. The nominal antioxidant activity towards the $\mathrm{DPPH}^{\circ}$ radical which could be provided by the film to the $95 \%$ ethanol simulant (considering $5 \%$ of green tea extract, no degradation, and full release) was $1.25 \mathrm{~g} / \mathrm{L}$ ascorbic acid equivalent. According to the results of the release (Figure 3.3), the extraction of the green tea components advances towards an almost complete release after two weeks of exposure.

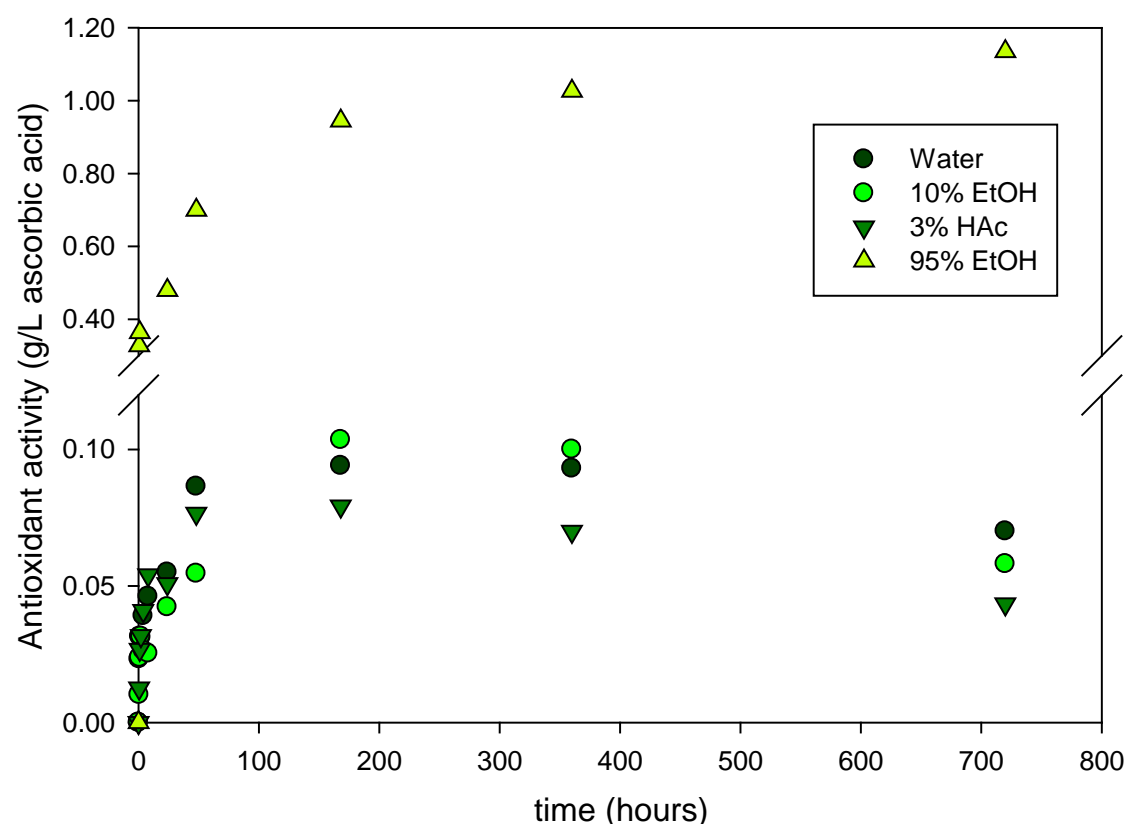

Figure 3.3. Antioxidant activity of green tea extract found in the food simulants tested during exposure to the EVOH-based materials determined by the DPPH• method (95\% ethanol) and by the ABTS ++ method for the aqueous simulants.

For the aqueous simulants, the nominal antioxidant activity against ABTS ${ }^{\circ+}$ which could be provided by the film to the water, 3\% acetic acid, and $10 \%$ ethanol simulants (considering $5 \%$ of green tea extract, no degradation, and full release) was $0.267 \mathrm{~g} / \mathrm{L}$ ascorbic acid equivalent. According to the release results (Figure 3.3), the extraction of the green tea components advances 
towards an equilibrium value that is ca. $35 \%$ of the nominal value. Besides a partial degradation of the green tea extract during extrusion, the low compatibility between the catechins and water reduced the extent of their release and subsequently considerably reduced the antioxidant activity on aqueous food simulants. According to the experimental values (Figure 3.3), equilibrium is achieved after 10 days for the three simulants. The highest extent was obtained for $10 \%$ ethanol, in the $0.10 \mathrm{~g} / \mathrm{L}$ range. Neutral and acidic aqueous simulants presented a maximum extent at 0.09 and $0.07 \mathrm{~g} / \mathrm{mL}$, respectively, reaching this value after 200 hours.

A reduction in this value was observed at longer exposure times, probably due to partial degradation of the active compounds in these solvents.

To determine the components of the green tea extract that were responsible for the antioxidant activity measured, the simulants were sampled and analyzed by HPLC. All compounds identified in the extracts (Figure 3.1) were observed in the four simulants, although the concentrations of the compounds were dependent on the type of simulant. The two main compounds that were released in all simulants were gallic acid and caffeine. Also, the five catechins were released from the polymeric films, although this release is more evident in $95 \%$ ethanol owing to the higher solubility of catechins in this solvent.

The identification of four of the compounds was confirmed by injection of pure standards: gallic acid, caffeine, catechin, and epigallocatechin gallate. The response of the HPLC was calibrated for these four compounds and their individual release was monitored during storage.

Table 3.4 summarizes the maximum release reached at equilibrium of each identified compound, expressed as ( $\mathrm{mg}$ of compound/g film), and as a percentage of the nominal content of each compound in the film. The release of gallic acid was very similar for all aqueous simulants, and caffeine was practically all extracted from the material developed. 
Table 3.4. Concentration of four identified green tea components, A) into the developed EVOH_GT5\% material, expressed as ( $\mathrm{mg}$ each compound $/ \mathrm{g}$ film), and B) released into the different food simulants, expressed as $\mathrm{mg} / \mathrm{g}$ film and (\% from that originally present in film).

\begin{tabular}{cccc}
\hline Gallic acid & Caffeine & Catechin & EGCG \\
\cline { 2 - 4 } & $(\mathrm{mg} / \mathrm{g}$ film $)$ &
\end{tabular}

\begin{tabular}{lllll}
\cline { 2 - 4 } A) EVOH_GT5\% & 4.84 & 5.01 & 2.71 & 2.48
\end{tabular}

B) Simulant

$\mathrm{mg} / \mathrm{g}$ film (\% released from film)

\begin{tabular}{lcccc}
\hline \hline Water & $2.86(59 \%)$ & $4.85(97 \%)$ & $1 \%$ & $1 \%$ \\
Acetic acid 3\% & $2.79(57 \%)$ & $4.63(97 \%)$ & $1 \%$ & $1 \%$ \\
Ethanol 10\% & $3.03(63 \%)$ & $4.80(93 \%)$ & $1 \%$ & $1 \%$ \\
Ethanol 95\% & $4.73(98 \%)$ & $4.86(96 \%)$ & $0.81(10 \%)$ & $0.32(6 \%)$ \\
\hline
\end{tabular}

The release of all identified components was higher in the 95\% ethanol simulant, especially for catechin and epigallocatechin gallate, whose releases on aqueous simulants were very small and within the limit of sensitivity of the experimental procedure (quantification was not attempted).

The extent of release at equilibrium (after a long exposure time) depends on the compatibility of the migrant with both the food simulant and the polymeric film. The higher the solubility in the simulant, the higher the release that should be expected. Caffeine with a water solubility of $23 \mathrm{~g} / \mathrm{L}$ is the most soluble compound in water and presented the largest extent.

The extent of release can be characterized by the partition coefficient $(K)$, defined as the ratio of the concentration of a compound in the polymeric phase to that in the food simulant. The values of $K$ are represented in Figure 3.4 and show that caffeine was the compound with the highest release in all simulants, migration being slightly lower in the acidic food simulant. 


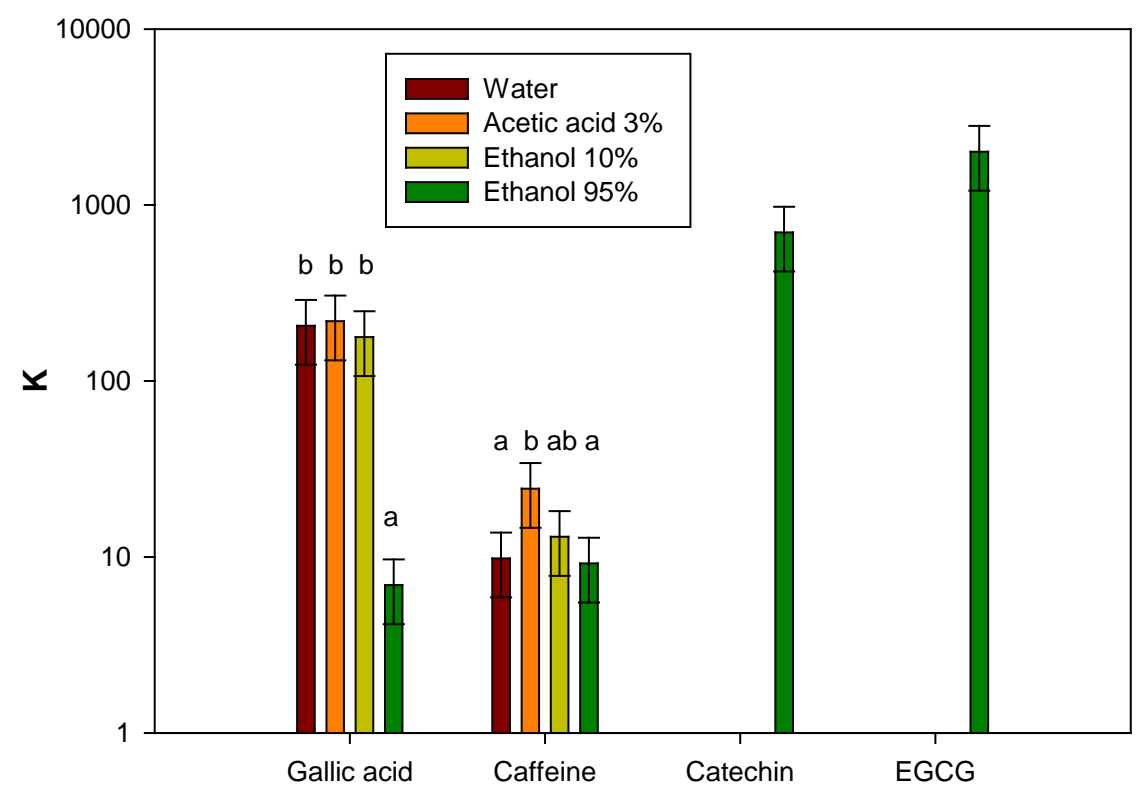

Figure 3.4. Partition coefficients of gallic acid, caffeine, catechin, and EGCG between EVOH and food simulants.

Similar $K$ values were obtained for gallic acid in the three aqueous simulants. The partition value favored the release into $95 \%$ ethanol to a larger extent $(p<$ 0.05). For the two catechins, the values obtained for the equilibrium constant were higher than for the other two compounds, indicating a limited release. Since both substances are very soluble in ethanol, a larger release close to full extraction could be expected, and $K$ values approaching 0 . No values were calculated for the release of catechins into aqueous simulants since the concentrations present large errors, although they could be expected to be well above 30000 .

The kinetics of the release of the various compounds was also monitored. Figure 3.5 shows the release of gallic acid and caffeine in the four simulants. As can be seen, the release kinetics of the compounds followed the same profile as antioxidant activity. Similar curves were obtained for the other components of the extract. The diffusion coefficient $(D)$ as defined in Fick's laws is commonly used to characterize the kinetics of transport in polymeric 
matrices. Kinetically, the release process depends on the diffusion of the migrant and the extent of the process. Considering that the release agents are rapidly dispersed in the food simulant, so that their concentration is homogeneous at all times, the release of a given compound from the polymer phase into the liquid phase at time $t(m(t))$ can be expressed as a function of the release at equilibrium (meq) and the values of the $D$ and $K$ coefficients (Crank, 1975):

$$
\frac{m(t)}{m_{S}^{f}}==1-\sum_{n=1}^{\infty} \frac{2 \alpha(1+\alpha)}{1+\alpha+\alpha^{2} q_{n}^{2}} \exp \left(-4 D q_{n}^{2} t / \ell^{2}\right)
$$

where $\alpha$ represents the ratio between the mass of compound in the liquid and that in the polymer at equilibrium $\left(\alpha=V_{S} /\left(K \cdot V_{P}\right), V_{S}\right.$ and $V_{P}$ are the volumes of simulant and polymer, and $q_{n}$ are the positive solutions of the equation:

$$
\operatorname{tg}\left(q_{n}\right)=-\alpha q_{n}
$$



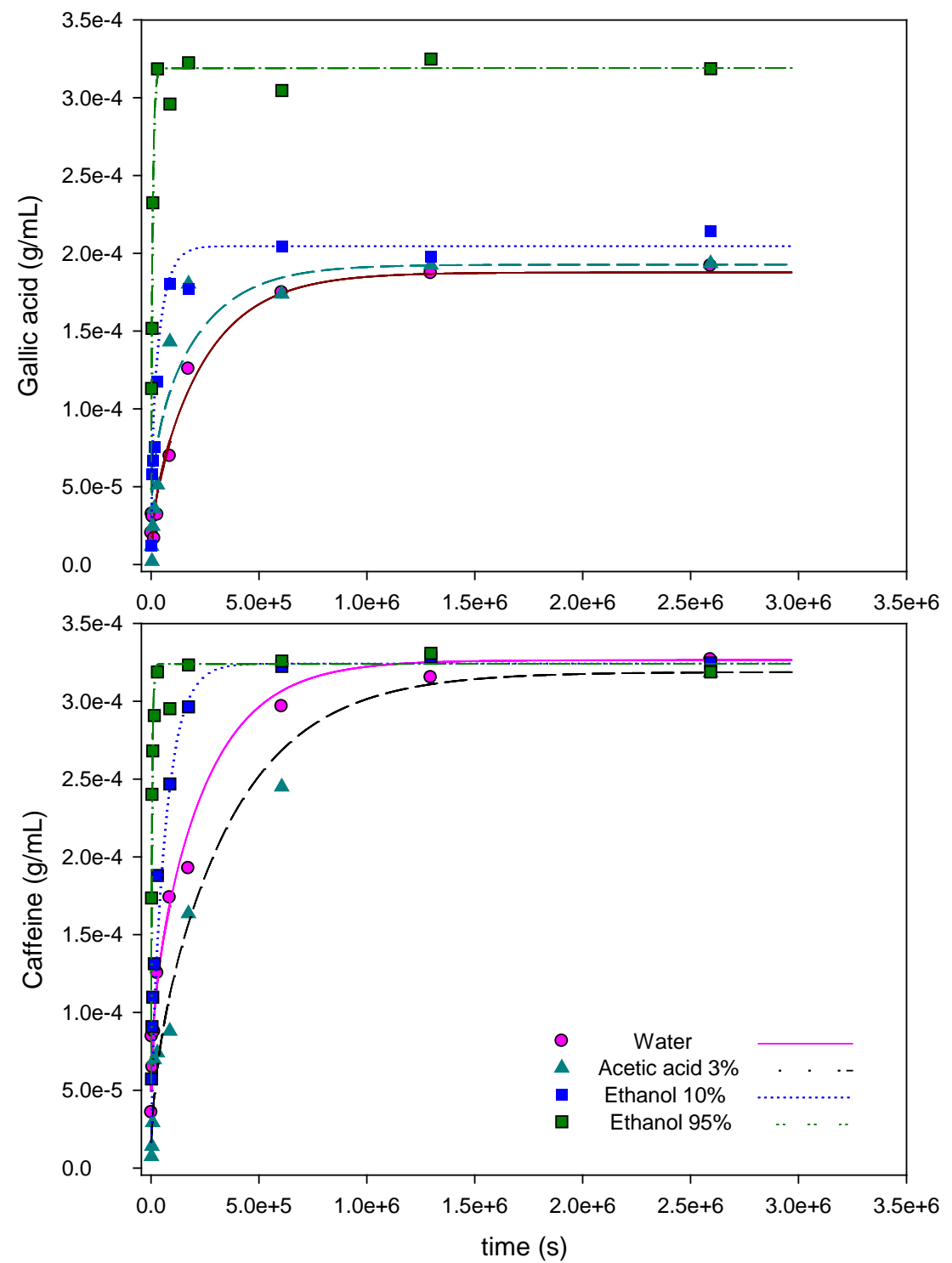

Figure 3.5. Release of gallic acid and caffeine from EVOH-based material into food simulants: symbols represent experimental data and lines are values predicted using equation (1) with $K$ and $D$ values included in Figures 3.4 and 3.6.

Figure 3.5 shows the curves obtained from eq. (1) using the $K$ values included in Figure 3.4 and the $D$ values that yielded the best fit to the experimental 
values (shown in Figure 3.6). As can be seen, there was good agreement between the theoretical values and the experimental release data.

The $D$ values for all compounds and simulants are plotted in Figure 3.6. As can be seen, gallic acid and caffeine had similar $D$ values in all simulants. With respect to the effect of simulant on the diffusivity of the antioxidants in the polymer matrix, the release from films contacting $95 \%$ ethanol is faster than from films exposed to aqueous simulants. The large interactions reported between low molecular weight alcohols and $\mathrm{EVOH}$ could result in a strong plasticization of the matrix, accelerating the agent release (Lagaron et al., 2001; Lopez-de-Dicastillo et al., 2010a).

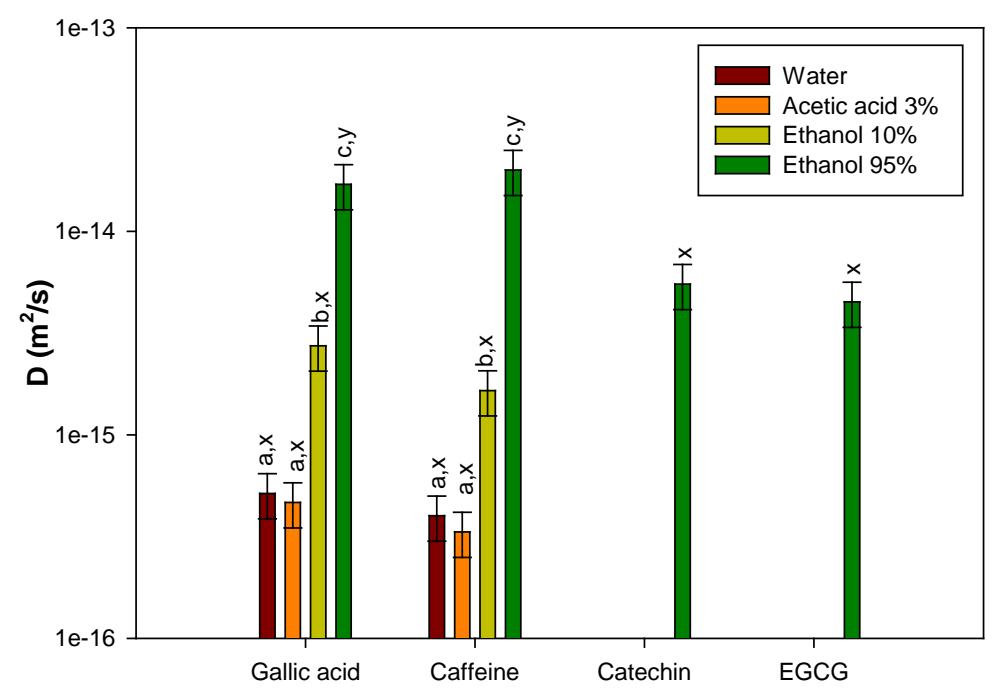

Figure 3.6. Diffusion coefficients of gallic acid, caffeine, catechin, and EGCG in films exposed to the tested food simulants obtained by fitting the experimental release using eq.

(1) for gallic acid and caffeine and eq. (2) for catechin and EGCG.

Figure 3.7 shows the release of the two catechins. As can be seen, the curves obtained with equation (1) did not describe the experimental results. To cast some light on the reason for this deviation, the model applicable to the release of compounds in an extraction process was attempted. Equation (2) is the Fick's solution to this case, in which diffusion is the only variable controlling the process: 


$$
\frac{m(t)}{m_{S}^{f}}=\left[1-\frac{8}{\pi^{2}} \sum_{n=0}^{\infty} \frac{1}{(2 n+1)^{2}} \exp \left(\frac{-D(2 n+1)^{2} \pi^{2} t}{\ell^{2}}\right)\right]
$$

Figure 3.7 also shows the theoretical results obtained using eq. (2). It is obvious that the extraction model describes the release of these two compounds better than the partition model. These results indicated that both catechin and EGCG were fully extracted during the exposure test, therefore the remains of these two compounds that remained in the polymer were not available for transport, that is, they were immobilized in the polymeric matrix. Only during the extraction process in hot ethanol were they released from the EVOH. Figure 3.6 also shows the $D$ values that best fit the experimental results for the two catechins. As can be seen, they are much lower than those calculated for gallic acid and caffeine. This difference was expected, since catechin and EGCG have a much larger molecular size than the other two compounds and a larger size results in more difficult transport and a lower $D$ value.

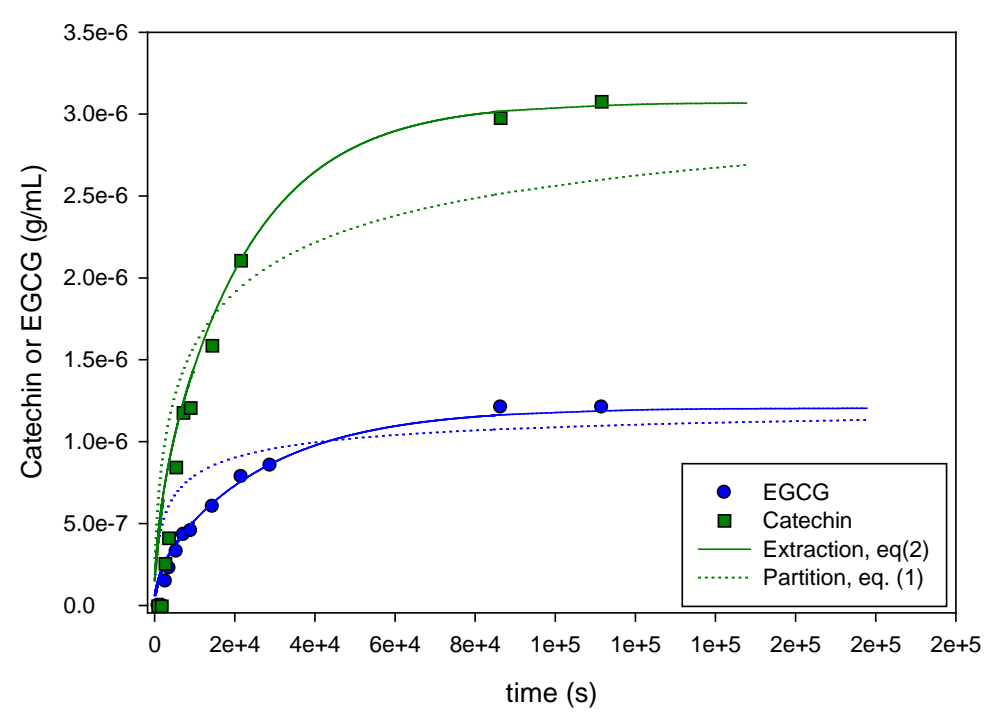

Figure 3.7. Release of catechin and EGCG from EVOH-based material into ethanol. Dots are experimental data and lines are the theoretical description obtained using eqs. (1)and (2). 


\section{ACKNOWLEDGEMENTS}

The authors acknowledge the financial support of the Spanish Ministry of Science and Innovation, projects AGL2006-02176, AGL2009-08776 and Fun-

C-Food CSD2007-00063, and the C. L-d-D fellowship (FPU program). Karel

Clapshaw provided assistance with the English language text.

\section{REFERENCES}

Aucejo, S., Catala, R., Gavara, R., (2000). Interactions between water and EVOH food packaging films. Food Science and Technology International 6(2), 159-164.

Bentayeb, K., Rubio, C., Batlle, R., Nerin, C., (2007). Direct determination of carnosic acid in a new active packaging based on natural extract of rosemary. Analytical and Bioanalytical Chemistry 389, 1989-1996.

Crank, J., (1975). The mathematics of diffusion., in: ed., n. (Ed.). Clarendon, Oxford.

Cuvelier, M.E., Bondet, V., Berset, C., (2000). Behavior of phenolic antioxidants in a partitioned medium: Structure-activity relationship. Journal of the American Oil Chemists Society 77(8), 819-823.

Dopico-Garcia, M.S., Castro-Lopez, M.M., Lopez-Vilarino, J.M., Gonzalez-Rodriguez, M.V., Valentao, P., Andrade, P.B., Garcia-Garabal, S., Abad, M.J., (2011). Natural Extracts as Potential Source of Antioxidants to Stabilize Polyolefins. Journal of Applied Polymer Science 119(6), 3553-3559.

Dudonne, S., Vitrac, X., Coutiere, P., Woillez, M., Merillon, J.M., (2009). Comparative Study of Antioxidant Properties and Total Phenolic Content of 30 Plant Extracts of Industrial Interest Using DPPH, ABTS, FRAP, SOD, and ORAC Assays. Journal of Agricultural and Food Chemistry 57(5), 1768-1774.

Gavara, R., Hernández, R.J., (1993). Consistency test for continuos flow permeability experimental data. , in: Sheeting, J.o.P.F. (Ed.), pp. 126-138.

Graham, H.N., (1992). Green tea composition, consumption, and polyphenol chemistry. Preventive Medicine 21(3), 334-350.

Gramza-Michalowska, A., Regula, J., (2007). Use of tea extracts (Camelia sinensis) in jelly candies as polyphenols sources in human diet. Asia Pacific Journal of Clinical Nutrition 16, 43-46.

Gramza, A., Korczak, J., (2004). Tea extracts influence on catalytical properties of Fe2+ in lipids. Polish Journal of Environmental Studies. 13, 143-146.

Granda-Restrepo, D.M., Soto-Valdez, H., Peralta, E., Troncoso-Rojas, R., VallejoCordoba, B., Gamez-Meza, N., Graciano-Verdugo, A.Z., (2009). Migration of alphatocopherol from an active multilayer film into whole milk powder. Food Research International 42(10), 1396-1402. 
Korczak, J., Janitz, W., Pokorny, J., Nogala-Kalucka, M., (1998). Synergism of natural antioxidants in stabilizing fat and oils., in: Koseoglu, S.S., Rhee, K.C., Wilson, R.F. (Eds.), Proceeding of World Conference on oilseed and edible oils processing., Champaign:AOCS Press. ed. World Conference on oilseed and edible oils processing advances in oils and fats, antioxidants and oilseed by-products., Instanbul-1996, pp. 253-255.

Lagaron, J.M., Powell, A.K., Bonner, G., (2001). Permeation of water, methanol, fuel and alcohol-containing fuels in high-barrier ethylene-vinyl alcohol copolymer. Polymer Testing 20(5), 569-577.

Lambert, J.D., Sang, S.M., Hong, J., Yang, C.S., (2010). Anticancer and Antiinflammatory Effects of Cysteine Metabolites of the Green Tea Polyphenol, (-)Epigallocatechin-3-gallate. Journal of Agricultural and Food Chemistry 58(18), 10016-10019.

Lin, L.Z., Chen, P., Harnly, J.M., (2008). New phenolic components and chromatographic profiles of green and fermented teas. Journal of Agricultural and Food Chemistry 56(17), 8130-8140.

Lopez-de-Dicastillo, C., Alonso, J.M., Catala, R., Gavara, R., Hernandez-Munoz, P., (2010a). Improving the Antioxidant Protection of Packaged Food by Incorporating Natural Flavonoids into Ethylene-Vinyl Alcohol Copolymer (EVOH) Films. Journal of Agricultural and Food Chemistry 58(20), 10958-10964.

Lopez-de-Dicastillo, C., Gallur, M., Catala, R., Gavara, R., Hernandez-Munoz, P., (2010b). Immobilization of beta-cyclodextrin in ethylene-vinyl alcohol copolymer for active food packaging applications. Journal of Membrane Science 353(1-2), 184191.

Martin-Diana, A.B., Rico, D., Barry-Ryan, C., (2008). Green tea extract as a natural antioxidant to extend the shelf-life of fresh-cut lettuce. Innovative Food Science \& Emerging Technologies 9(4), 593-603.

Nerín, C., (2010). Antioxidant active food packaging and antioxidant edible films Chapter 31 of "Oxidation in foods and beverages and antioxidant applications". , in: Decker, E.A., Elias, R.J., McClements, D.J. (Eds.). Woodhead Publishing Series in Food Science, Technology and Nutrition., pp. 496-515.

Nerín, C., Tovar, L., Djenane, D., Camo, J., Salafranca, J., Beltran, J.A., Roncales, P., (2006). Stabilization of beef meat by a new active packaging containing natural antioxidants. Journal of Agricultural and Food Chemistry 54(20), 7840-7846.

Okada, Y., Okada, M., (1998). Scavenging effect of water soluble proteins in broad beans on free radicals and active oxygen species. Journal of Agricultural and Food Chemistry 46(2), 401-406.

Pedrielli, P., Pedulli, G.F., Skibsted, L.H., (2001). Antioxidant mechanism of flavonoids. Solvent effect on rate constant for chain-breaking reaction of quercetin and epicatechin in autoxidation of methyl linoleate. Journal of Agricultural and Food Chemistry 49(6), 3034-3040.

Peltzer, M., Wagner, J., Jimenez, A., (2009). Migration study of carvacrol as a natural antioxidant in high-density polyethylene for active packaging. Food Additives and 
Contaminants Part a-Chemistry Analysis Control Exposure \& Risk Assessment 26(6), 938-946.

Pereira de Abreu, D.A.P., Losada, P.P., Maroto, J., Cruz, J.M., (2010). Evaluation of the effectiveness of a new active packaging film containing natural antioxidants (from barley husks) that retard lipid damage in frozen Atlantic salmon (Salmo salar L.). Food Research International 43(5), 1277-1282.

Pezo, D., Salafranca, J., Nerin, C., (2008). Determination of the antioxidant capacity of active food packagings by in situ gas-phase hydroxyl radical generation and highperformance liquid chromatography-fluorescence detection. Journal of Chromatography A 1178(1-2), 126-133.

Poon, G.K., (1998). Analysis of catechins in tea extracts by liquid chromatography electrospray ionization mass spectrometry. Journal of Chromatography A 794(1-2), 63-74.

Prior, R.L., Wu, X.L., Schaich, K., (2005). Standardized methods for the determination of antioxidant capacity and phenolics in foods and dietary supplements. Journal of Agricultural and Food Chemistry 53(10), 4290-4302.

Rietveld, A., Wiseman, S., (2003). Antioxidant effects of tea: Evidence from human clinical trials. Journal of Nutrition 133(10), 3285S-3292S.

Saito, S.T., Froehlich, P.E., Gosmann, G., Bergold, A.M., (2007). Full validation of a simple method for determination of catechins and caffeine in Brazilian green tea (Camellia sinensis var. assamica) using HPLC. Chromatographia 65(9-10), 607610.

Sanchez-Moreno, C., (2002). Review: Methods used to evaluate the free radical scavenging activity in foods and biological systems. Food Science and Technology International 8(3), 121-137.

Tovar, L., Salafranca, J., Sanchez, C., Nerin, C., (2005). Migration studies to assess the safety in use of a new antioxidant active packaging. Journal of Agricultural and Food Chemistry 53(13), 5270-5275.

Wanasundara, U.N., Shahidi, F., (1998). Antioxidant and pro-oxidant activity of green tea extracts in marine oils. Food Chemistry 63(3), 335-342.

Yamamoto, T., Kanda, T., Nishihara, Y., Ooshima, T., Saito, Y., (2009). Correlation Study among Oxygen Permeability, Molecular Mobility, and Amorphous Structure Change of Poly(ethylene-vinylalcohol copolymers) by Moisture. Journal of Polymer Science Part B-Polymer Physics 47(12), 1181-1191.

Zeeb, D.J., Nelson, B.C., Albert, K., Dalluge, J.J., (2000). Separation and identification of twelve catechins in tea using liquid chromatography/atmospheric pressure chemical ionization-mass spectrometry. Analytical Chemistry 72(20), 5020-5026.

Zhu, K.X., Lian, C.X., Guo, X.N., Peng, W., Zhou, H.M., (2011). Antioxidant activities and total phenolic contents of various extracts from defatted wheat germ. Food Chemistry 126(3), 1122-1126. 
Zuo, Y.G., Chen, H., Deng, Y.W., (2002). Simultaneous determination of catechins, caffeine and gallic acids in green, Oolong, black and pu-erh teas using HPLC with a photodiode array detector. Talanta 57(2), 307-316. 
Artículo 4

ACTIVE ANTIOXIDANT PACKAGING FILMS:

DEVELOPMENT AND EFFECT ON LIPID STABILITY OF BRINED SARDINES

Carol López-de-Dicastillo, Joaquín Gómez Estaca, Ramón Catalá,

Rafael Gavara, Pilar Hernández-Muñoz

Submitted to Journal of Food Chemistry 


\section{ABSTRACT}

Active antioxidant food packaging films were produced by the incorporation of ascorbic acid, ferulic acid, quercetin and green tea extract into an ethylene vinyl alcohol copolymer (EVOH) matrix. The characterization of the thermal and barrier properties of the film developed showed that the addition of these bioactive compounds did not greatly modify their properties. However, the presence of ascorbic and ferulic acid resulted in a significant decrease in water vapor permeability, possibly due to their high affinity to water of these substances. Exposure of the films to various food simulants showed that the release from films was dependent on the type of food simulant and the antioxidant incorporated: in the aqueous food simulant, materials containing ascorbic acid presented the largest release; in the fatty food simulant, quercetin and green tea extract presented the best performance. The efficiency of the films developed was determined by real packaging applications of brined sardines. The evolution of the peroxide index and the malonaldehyde content showed that, in general, the films improved sardine stability. Films with green tea extract offered the best protection against lipid oxidation.

Keywords: active packaging, antioxidant release, EVOH, sardines, lipid oxidation 


\section{INTRODUCTION}

Active packaging with antioxidant properties have received special attention, since they are one of the most promising alternatives to traditional packaging, in which antioxidants are incorporated into or coated onto food packaging materials to reduce oxidation of the food, which is one of the main causes of food spoilage.

In this connection, several groups have reported on the release of purposeful added antioxidants from packaging films. Wessling et al. (1998) reported the release of butylated hydroxytoluene $(\mathrm{BHT})$ and tocopherol from polyethylene films into fatty food simulants, and Torres-Arreola et al. (2007) reported the delay of lipid oxidation and of protein denaturation by the incorporation of butylated hydroxytoluene (BHT) into low-density polyethylene. Nowadays, the tendency to reduce the use of synthethic additives in packaging has focused interest on their substitution by natural antioxidants, particularly tocopherol, plant extracts, and essential oils from herbs such as rosemary, oregano, and tea, that are safer and in most cases offer multiple health benefits. GrandaRestrepo et al. (2009) developed polyethylene films with a-tocopherol and measured its release into milk powder. Gemili et al. (2010) studied the release of ascorbic acid and L-tyrosine from a cellulose acetate based film. Garces et al. (2003) patented an antioxidant varnish based on the addition of plant extracts for food protection and Nerin et al. (2006) reported its efficiency in the stabilization of beef meat.

In this work, active antioxidant films for the packaging of oxygen-sensitive foods, based on an ethylene-vinyl alcohol copolymer (EVOH 29) and four natural antioxidants, were developed by casting. $\mathrm{EVOH}$ is a common packaging material that is well known for its excellent oxygen barrier properties and its highly hydrophilic nature (Aucejo et al., 2000). Recently, EVOH materials have been used as matrices for the development of active packaging systems, where the polymer protects the active agents during storage and trigger their activity upon exposition to a humid environment (the food product) (López-de-Dicastillo et al., 2010; López-de-Dicastillo et al., 2010; López-de- 
Dicastillo et al., 2011). This release from the polymeric film to the food is a complex process, affected mainly by the properties of the polymer matrix, the nature of the antioxidant and the characteristics of the food product. To check the applicability of the developed films they were used in the protection of sardines.

Sardines are fatty fish that contain high levels of $\omega-3$ polyunsaturated fatty acids, and their consumption has been considered very beneficial to human health, e.g. for cardiovascular diseases and arteriosclerosis. However, owing to this high polyunsaturated lipid content, fatty fish are very susceptible to loss of nutritional quality and shortening of shelf life because of lipid oxidation. Although the use of natural antioxidants to delay oxidation in fish muscle is widely studied (Giménez et al., 2005; Serdaroglu \& Felekoglu, 2003), the incorporation of these antioxidants in polymer as an active packaging application is quite innovative and limited. Pereira de Abreu et al. (2010) have studied the antioxidant activity of LDPE films with a natural antioxidant from barley husks on frozen Atlantic salmon lipid oxidation. Gómez-Estaca et al. (2007) managed to delay lipid oxidation of smoked sardines with the development of a film based on gelatin with rosemary and oregano aqueous extracts. A gelatin film added with a borage extract was also effective in reducing lipid oxidation of frozen fish patties (Giménez et al., 2011). Jung et al. (2009) have also developed a film covered with microcapsules of chitosan with volatile horseradish extract for refrigerated preservation of fresh mackerel.

The present work has an important advantage compared to most of the abovementioned references, which is the non-volatile, non-aromatic nature of the antioxidant agents, which should reduce any effect on the sensorial quality of the final product. Ascorbic acid is one of the most used antioxidants in the food industry. It is water-soluble, but it is easily oxidized and degraded when exposed to oxygen, metals, light or heat. Ferulic acid is a component of lignocelluloses, and serves to crosslink the lignin and polysaccharides, giving rigidity to cell walls. It is found in seeds of plants such as in rice, wheat, and oats. Ascorbic and ferulic acid owe their antioxidant activity to the hydroxyl 
groups. Catechins are the principal components of green tea extract, and like quercetin, are bioflavonoids. They present a well-known antioxidant activity due to the catechol group, among others substituents.

The resulting materials were characterized to analyze the effect of the addition of the antioxidants, and the casting process on EVOH functional properties, and their antioxidant activity in food was determined by monitoring the release of active agents into different food simulants, analyzing the scavenging capacity of radical oxidizing compounds, as well as their application as sardine packaging. The lipid oxidation of sardines was monitored by peroxide and TBARS values.

\section{MATERIALS AND METHODS}

\subsection{Chemicals and Reagents}

An ethylene vinyl alcohol copolymer with a $29 \%$ ethylene molar content (EVOH) was kindly provided by The Nippon Synthetic Chemical Company, (Osaka, Japan). Reagent-grade absolute ethanol, 1-propanol, ascorbic acid, quercetin dihydrate, ferulic acid, 2,2-diphenyl-1-picrylhydrazyl 95\% free radical, acetic acid, starch and 2-thiobarbituric acid were purchased from Sigma (Madrid, Spain). Green tea extract was supplied by Plantextrakt, the nature network (Baceiredo S.L., Vitoria, Spain). Chloroform, methanol, potassium iodide, sodium thiosulfate and trichloroacetic acid were purchased from Panreac Química (Barcelona, Spain). Water was obtained from a Milli-Q Plus purification system (Millipore, Molsheim, France).

\subsection{Film Preparation}

EVOH films containing ascorbic acid, ferulic acid, quercetin and green tea extract were obtained by a solution-extension-evaporation process (casting). The polymer was dissolved in a 1:1 (v:v) 1-propanol-water mixture at $75{ }^{\circ} \mathrm{C}$ and the antioxidants were incorporated at $5 \%$ (w/w respect to polymer weight). Casting was done with a wire wound bar coater on a glass plate. Film drying was accomplished by using a heating tunnel $\left(80^{\circ} \mathrm{C}\right)$ with ventilation during 3 
minutes, and then transferred to a chamber at $40^{\circ} \mathrm{C}$ and $14 \% \mathrm{RH}$ during 24 hours. The thickness of every sample was individually measured before tests using a digital Mitutoyo micrometer (Metrotec, San Sebastian, Spain) with an average value of $25 \pm 2 \mu \mathrm{m}$. Finally, the films were vacuum packaged in aluminum/LDPE bags and stored at room temperature until the moment of analysis.

Antioxidant concentration and antioxidant activity in the films were determined by two consecutive extractions in ethanol at $65^{\circ} \mathrm{C}$ during 3 hours and analysis of the extracts by UV-Vis spectroscopy and by the DPPH. method, respectively.

\subsection{Thermal analysis}

Thermogravimetric analysis (TGA) was carried out using a Mettler Toledo TGA/SDTA/851 thermal analyzer (Columbus $\mathrm{OH}$, USA). The samples were heated from room temperature to $900{ }^{\circ} \mathrm{C}$ at $10^{\circ} \mathrm{C} / \mathrm{min}$ under a nitrogen atmosphere to analyze the evaporation of volatile compounds and the thermal degradation of the materials developed.

The glass transition temperature $(\mathrm{Tg})$ and the melting temperature $\left(\mathrm{T}_{\mathrm{m}}\right)$ and enthalpy $\left(\Delta \mathrm{H}_{\mathrm{m}}\right)$ of the samples were also determined by differential scanning calorimetry with a DSC Model Q2000 from TA Instruments (New Castle, DE, EEUU). Materials were dried in a vacuum oven at $50^{\circ} \mathrm{C}$ during two days to evaporate the residual solvent. Thermograms from $-20{ }^{\circ} \mathrm{C}$ to $220{ }^{\circ} \mathrm{C}$ with 10 ${ }^{\circ} \mathrm{C} /$ min heating, cooling to $-20{ }^{\circ} \mathrm{C}$ and a second heating process to $220{ }^{\circ} \mathrm{C}$ were obtained. Considering the polymer percentage of each sample, a corrected enthalpy $\left(\Delta \mathrm{Hm}_{\text {cor }}\right)$ value was also estimated.

\subsection{Barrier Properties}

\subsubsection{Water Vapor Permeability}

WVP tests were carried out at $33 \%$ and $90 \% \mathrm{RH}$ and $23{ }^{\circ} \mathrm{C}$ using permeability cups (Elcometer, Manchester, England) in accordance with ISO 2528. The 
aluminum cups were filled with $7 \mathrm{~g}$ of silica gel and sealed with vacuum silicon grease (Sigma, Barcelona, Spain) and the film to be tested. The film was fixed in place with a flat Viton ring, an aluminum ring, and three press-screws. To ensure the necessary relative humidity, the cups were then stored in desiccators containing salt solutions: barium chloride, $\mathrm{BaCl}_{2}$, and magnesium chloride, $\mathrm{MgCl}_{2}$, for $33 \%$ and $90 \% \mathrm{RH}$, respectively. The cups were weighed daily, and the plot of the weight increment vs. time provided the water vapor transmission rate. These values were then divided by the water pressure gradient and multiplied by the sample thickness to obtain the water vapor permeability value.

\subsubsection{Oxygen Permeability}

The oxygen permeation rates of the materials were determined at $35 \%$ and $90 \% \mathrm{RH}$ and $23^{\circ} \mathrm{C}$ using a OXTRAN Model 2/21 ML Mocon (Lippke, Neuwied, Germany). After conditioning the samples in the permeation cells for 6 hours, the transmission values were determined every 45 min until constant.

\subsection{Antioxidant release tests}

A study of the release of the active compounds from the films was carried out by determining the specific migration from the polymer into the different food simulants specified in European law: water was used as an aqueous food simulant, $10 \%$ ethanol as an alcoholic food simulant and $95 \%$ ethanol as fatty food simulant. Migration studies were conducted at $37^{\circ} \mathrm{C}$. Double-sided, total immersion migration tests were performed as follows: a $3 \mathrm{~cm}^{2}$ piece of each plastic sample and $5 \mathrm{~mL}$ of the simulant (area-to-volume ratio around $6 \mathrm{dm}^{2} / \mathrm{L}$ ) were placed in Sovirel tubes covered with aluminum foil to protect the content from light. Simulants were deoxygenated by bubbling nitrogen, and a final nitrogen flush was done before closing the cells to reduce the oxygen percentage in the cell headspace. Antioxidant solutions in water and alcohol using this procedure were stable for one month except for the ascorbic acid aqueous solutions, which degraded during storage. Periodically, three vials were opened and the concentration of the antioxidant in the simulants was 
analyzed by UV-Vis spectroscopy. Using absorbance/concentration $(\mathrm{g} / \mathrm{mL})$ calibration curves, the results can be expressed as the concentration of each antioxidant released into the simulants. From the evolution of antioxidant concentration in the various simulants tested, the values of the diffusion coefficients $(D)$ of the antioxidants in the EVOH films were calculated assuming the fulfillment of Fick's laws. From the concentration values at equilibrium, the partition constant $(K)$ of each antioxidant in the various film/simulant systems was estimated.

At the same time, the antioxidant activity provided by the films was evaluated by measuring the radical scavenging ability of the food simulants, using the method of Okada and Okada with a slight modification (Okada \& Okada, 1998). The bleaching rate of a stable free radical, 2,2-diphenyl-1-picrylhydrazyl (DPPH.), was monitored at a characteristic wavelength in the presence of the sample. In its radical form DPPH. absorbs at $517 \mathrm{~nm}$, but upon reduction by an antioxidant or a radical compound its absorption decreases. The percentage inhibition values were calculated using equation 1 :

Using a calibrated curve of ascorbic acid concentration vs. I (\%), the results can be expressed easily as the equivalent ascorbic acid concentration. The antioxidant activity of the antioxidants selected was also determined by this method. $1 \mathrm{~g}$ of ascorbic acid was equivalent to approximately $0.981 \pm 0.021 \mathrm{~g}$ of ferulic acid, $0.779 \pm 0.023 \mathrm{~g}$ of quercetin and $0.898 \pm 0.038 \mathrm{~g}$ of green tea extract.

\subsection{Sardine processing and packaging}

Approximately $5 \mathrm{Kg}$ of sardines (Sardina pilchardus) caught during the month of February were purchased at a local market in Valencia (Spain) and brined using the procedure described by Gómez-Estaca et al. (2007). Briefly, sardines were headed and gutted, the backbone removed, and cut into two fillets that were washed in cold tap water. The skin was not removed. Salting 
was performed by immersion in brine $\left(15 \mathrm{~g} \mathrm{NaCl} / 100 \mathrm{~mL}\right.$ tap water) at $20^{\circ} \mathrm{C}$ for $10 \mathrm{~min}$. The fillets were then rinsed under cold tap water and suitably dried with absorbent paper. The salt content of fillets thus processed is about $3 \pm 0.1$ $\mathrm{g} \mathrm{NaCl} / 100 \mathrm{~mL}$ muscle.

For sardine packaging, eight sardine fillets per package, which were randomly taken from the total amount of brined fillets, were wrapped with the active films developed (each sardine fillet was in contact with the active film on both sides) and placed in a tray of PP/EVOH/PP $(20 \times 15 \times 2 \mathrm{~cm})$ that was closed with a 50 $\mu \mathrm{m}$ thick OPP/CPP thermosealed film with atmospheric air. A control batch was also prepared by wrapping the sardine fillets with an EVOH film without any intentionally added antioxidants. Samples were kept at $4 \pm 0.5^{\circ} \mathrm{C}$ for 13 days in dark conditions. At days 3, 5, 7, 10 and 13 of storage two trays per batch were opened, the films thrown out and the sardine's skins removed prior to muscle analyses.

\subsection{Oxidative status analyses of brined packaged sardines}

Both the primary oxidation products and the secondary ones were monitored over the storage period, by means of the peroxide and TBARS indices, respectively. Lipid extraction was carried out according to the method of Bligh \& Dyer (1959), resulting in a fat content of $1.27 \pm 0.2 \mathrm{~g} / 100 \mathrm{~g}$ muscle. The peroxide index was assayed according to UNE standard 55-023-73 (1973), and the results have been expressed in milliequivalents of peroxides per $\mathrm{kg}$ of fat. The thiobarbituric acid reactive substances were assayed according to the method of Vyncke (1970), and results have been expressed as mg of malondialdehyde/ $\mathrm{Kg}$ fat based on a standard curve constructed with 1,1,3,3tetraethoxypropane as per Botsoglou et al. (1994).

\subsection{Statistical analysis}

One-way and two-way analyses of variance were carried out using the SPSS ${ }^{\circledR}$ computer program (SPSS Inc., Chicago, IL, USA). Differences in pairs of 
mean values were evaluated by the Tukey test for a confidence interval of $95 \%$. Data are represented as mean \pm standard deviation.

\section{RESULTS AND DISCUSSION}

$25 \mu \mathrm{m}$ thick EVOH films containing ascorbic acid, ferulic acid, quercetin and green tea extract as antioxidant agents were successfully produced by casting. This technique has the advantage of reducing thermal degradation of the antioxidants with respect to conventional extrusion and can be compared to film coating techniques from a technological point of view. All these films were flexible, transparent and without visual discontinuities. Films with quercetin were slightly yellow and those with green tea extract showed a slightly brown coloration.

The final content of the diverse antioxidants in the films was determined by UV-Vis spectroscopy via a previous extraction with ethanol. The final concentrations are presented in Table 4.1. As can be seen, the final content of the various additives was slightly below the $5 \%$ nominal content, probably owing to some degradation caused during processing. To assess the antioxidant activity of the extracted agents, an analysis of the radical scavenging activity was carried out by the DPPH. method and the results are also included in Table 4.1. This test revealed that the two methodologies, spectroscopy and radical scavenging, provided similar results for ascorbic acid, quercetin and green tea extract. However, significant differences were observed for ferulic acid, whose antioxidant capacity was well below that expected from the concentration measured by UV-Vis spectroscopy. 
Table 4.1. Concentration of antioxidant in the developed films measured by ethanol extraction followed by UV-Vis spectroscopy analysis or by DPPH. method.

\begin{tabular}{ccc}
\hline \multicolumn{3}{c}{ Concentration of antioxidant in films (g/100g of film) } \\
\hline Uscorbic acid & $4.31 \pm 0.32 \mathrm{a}$ & $\mathrm{DPPH} \cdot$ method \\
\cline { 2 - 3 } Ferulic acid & $3.97 \pm 0.31 \mathrm{~b}$ & $4.06 \pm 0.52 \mathrm{a}$ \\
Quercetin & $4.61 \pm 0.05 \mathrm{a}$ & $2.18 \pm 0.06 \mathrm{a}$ \\
Green tea extract & $4.89 \pm 0.26 \mathrm{a}$ & $4.58 \pm 0.10 \mathrm{a}$ \\
\end{tabular}

Different letters in the same row indicate significant differences.

Interactions between the polymer and this phenolic acid may be responsible for this activity reduction since an independent experiment showed that the extraction process did not have any effect on ferulic acid.

\subsection{Thermal characterization}

TGA and DSC tests were carried out to study the influence of the casting process and the addition of antioxidants on the thermal stability and morphology of the polymer. The thermograms are presented in Figures 4.1 and 4.2 and the most relevant results are listed in Tables 4.2 and 4.3.

Figure 4.1 shows the TGA thermograms of the developed films, and, more specifically, the derivative of the weight loss with temperature versus temperature. As can be seen, they present multiple features. To determine their individual contributions to the mass loss, the wide bands presented in the derivative curve were deconvoluted using Origin software with Gaussian or Lorentzian fitting. In all cases, a good fit was observed with $\mathrm{R}^{2}>0.99$. 


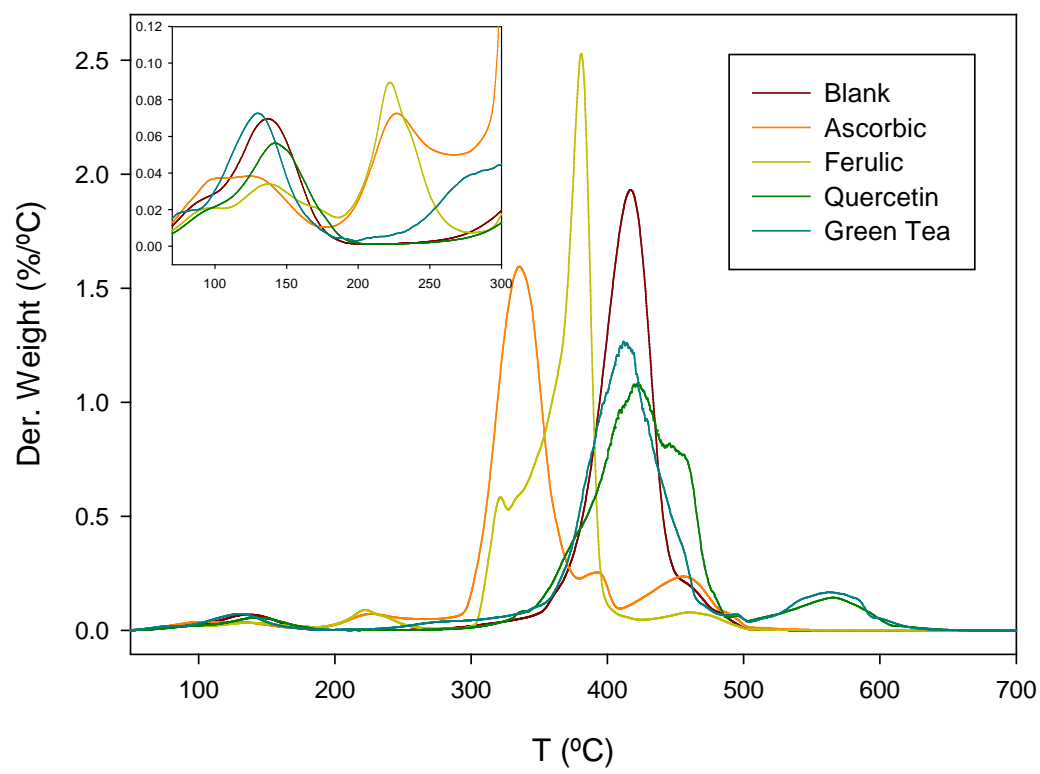

Figure 4.1. Derivative of the weight loss of $\mathrm{EVOH}$ materials containing natural antioxidants. Insert: magnified image of the dehydration process.

All thermograms presented a first feature with a maximum at ca. $130^{\circ} \mathrm{C}$ (as can be seen in the insert of Figure 4.1). This weight loss, ranging between 3.0 and $3.4 \%$ (see Table 4.2), was attributed to the evaporation of the residual solvent mixture, water and 1-propanol, from the film manufacturing process. These values were similar to that of quercetin and slightly lower (significantly different) than those measured for the green tea sample and the blank. The plot also showed that the evaporation of solvent in the films containing ascorbic and ferulic acids occurred in a wider temperature range and overlapped with a second weight loss with a maximum at about $227^{\circ} \mathrm{C}$. The second transition could be assigned to the degradation of the antioxidants with weight losses of 3.3 and 1.0 for the films containing ferulic and ascorbic acid, respectively. Independent TGA analysis of the pure compounds confirmed the presence of degradation peaks at $232.2^{\circ} \mathrm{C}$ for ferulic acid and $249.2^{\circ} \mathrm{C}$ for ascorbic acid. 
The second and biggest process for all the materials corresponded to the thermal degradation of the polymer and occurred from 300 to $500{ }^{\circ} \mathrm{C}$. The control sample had a single band with maximum at $414.0^{\circ} \mathrm{C}$ and responsible for $95 \%$ of the sample weight loss. The curves obtained for the materials with quercetin and green tea extract had a main degradation process at 420.4 and $412.4^{\circ} \mathrm{C}$, respectively, similar to that of the blank sample, although $14 \%$ and $12 \%$ of the weight loss of these samples happened at higher temperatures, probably due to the protection of these agents.

Table 4.2. Degradation peaks expressed as temperature of the minimum at the derivative and attributed percentage of the weight loss (WL).

\begin{tabular}{|c|c|c|c|c|c|c|c|c|c|c|}
\hline Material & $\begin{array}{l}\text { Dehyc } \\
\text { proc }\end{array}$ & $\begin{array}{l}\text { tion } \\
\text { ss }\end{array}$ & \multicolumn{8}{|c|}{ Degradation Peaks from TGAs $\left({ }^{\circ} \mathrm{C}\right)$} \\
\hline \multirow[b]{2}{*}{ Blank } & $\begin{array}{c}\mathrm{T} \\
\left({ }^{\circ} \mathrm{C}\right)\end{array}$ & $\begin{array}{l}\text { WL } \\
\text { (\%) }\end{array}$ & $\begin{array}{c}\mathrm{T} \\
\left({ }^{\circ} \mathrm{C}\right)\end{array}$ & $\begin{array}{l}\text { WL } \\
(\%)\end{array}$ & $\begin{array}{c}\mathrm{T} \\
\left({ }^{\circ} \mathrm{C}\right)\end{array}$ & $\begin{array}{l}\text { WL } \\
\text { (\%) }\end{array}$ & $\begin{array}{c}\mathrm{T} \\
\left({ }^{\circ} \mathrm{C}\right)\end{array}$ & $\begin{array}{l}\text { WL } \\
\text { (\%) }\end{array}$ & $\begin{array}{c}\mathrm{T} \\
\left({ }^{\circ} \mathrm{C}\right)\end{array}$ & $\begin{array}{l}\text { WL } \\
\text { (\%) }\end{array}$ \\
\hline & 135.0 & 4.3 & & & 414.0 & 95.7 & & & & \\
\hline Ascorbic & 116.5 & 3.4 & 227.4 & 1.0 & 335.6 & 73.7 & 388.1 & 8.4 & 451 & 13.8 \\
\hline Ferulic & 133.5 & 3.0 & 226.2 & 3.3 & 353.4 & 55.0 & 380 & 34.2 & 459 & 4.5 \\
\hline Quercetin & 139.8 & 3.6 & & & 420.4 & 82.6 & 457 & 4.7 & 561 & 9.2 \\
\hline Green tea & 127.0 & 4.2 & & & 412.4 & 84.2 & 559 & 11.7 & & \\
\hline
\end{tabular}

On the other hand, the materials with ascorbic and ferulic acid presented earlier degradation, possibly initiated by the agents' degradation.

DSC analysis was carried out to determine the thermal transitions of the materials developed. First analyses of the samples (not shown) were affected by the presence of solvent residues, which was reflected as an endotherm that partially hid the endset of $T_{g}$ and the beginning of the melting process. Therefore, samples were rigorously dried under vacuum before analysis. Figure 4.2 presents the DSC thermograms correspondent to the first heating 
process and Table 4.3 summarizes the main information obtained from the DSC analysis, together with literature values for extruded EVOH films. As can be seen, the type of processing results in a significant change in the thermal properties of EVOH films. The EVOH film obtained by casting had a lower melting temperature and a reduction of melting enthalpy as compared to extruded EVOH films (López-Rubio et al., 2007).

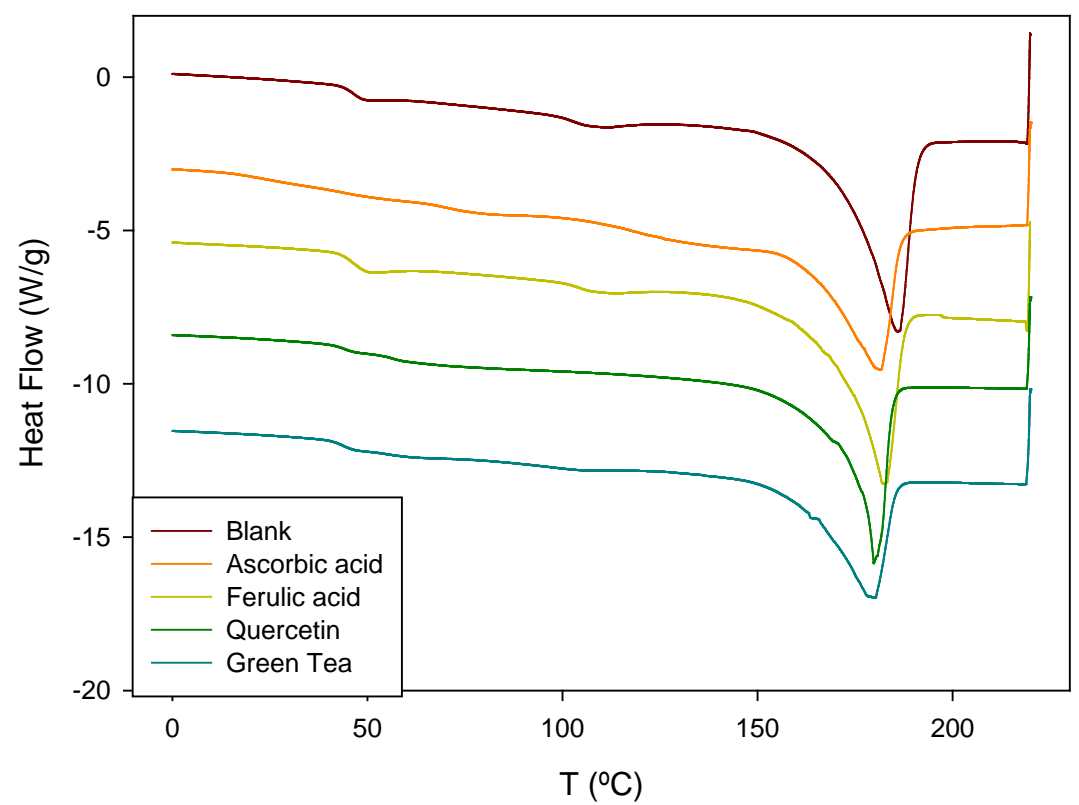

Figure 4.2. DSC thermograms of EVOH-based materials during the first heating.

These two features are consequence of a lower and more deficient crystallinity structure. Also, the thermograms reflected a slight reduction in the $T_{g}$ values (Aucejo at al., 1999), although the difference were not significant.

The incorporation of the agents also results in changes in the thermal properties of the films. Samples containing ascorbic and ferulic acids were more flexible, as indicated by a decrease of $3^{\circ} \mathrm{C}$ in $\mathrm{T}_{\mathrm{g}}$. No significant differences were observed between the samples containing quercetin or green tea and the blank film. With respect to the melting behavior, a general decrease in the minimum of the endotherms was observed in the samples 
incorporating antioxidants although their effect does not affect relevantly to the melting enthalpy (percentage crystallinity). A colder melting process over a wider temperature range is related to a more deficient crystalline structure. The presence of the antioxidants probably produces two antagonistic effects: a nucleating effect on the polymer which induces the growth of a large number of crystals, and a decrease in crystal size because of imperfections (Xu et al., 2003).

Table 4.3. Thermal parameters obtained by DSC for the EVOH-based materials during the first heating.

\begin{tabular}{lcccc}
\hline Material & $\mathrm{T}_{\mathrm{g}}{ }^{\circ} \mathrm{C}$ & $\mathrm{T}_{\mathrm{f}}{ }^{\circ} \mathrm{C}$ & $\Delta \mathrm{H}(\mathrm{J} / \mathrm{g})$ & $\Delta \mathrm{H}_{\text {cor. }}(\mathrm{J} / \mathrm{g})$ \\
\hline $\mathrm{EVOH}^{*}$ & $47.5^{\star}$ & $186^{\star}$ & $70.6^{\star}$ & $70.6^{\star}$ \\
\hline Blank. & $46.7 \pm 2.1 \mathrm{~b}$ & $183.6 \pm 1.6 \mathrm{~b}$ & $65.6 \pm 1.7$ & $65.6 \pm 1.7 \mathrm{~b}$ \\
& & & & \\
Ascorbic acid & $43.8 \pm 0.7 \mathrm{a}$ & $179.3 \pm 2.4 \mathrm{ab}$ & $54.3 \pm 2.0$ & $57.2 \pm 2.4 \mathrm{a}$ \\
Ferulic acid & $43.4 \pm 1.1 \mathrm{a}$ & $176.5 \pm 6.0 \mathrm{a}$ & $60.9 \pm 1.1$ & $64.1 \pm 1.2 \mathrm{~b}$ \\
Quercetin & $46.9 \pm 2.2 \mathrm{~b}$ & $177.4 \pm 2.9 \mathrm{a}$ & $62.7 \pm 0.9$ & $66.0 \pm 1.0 \mathrm{~b}$ \\
Green Tea & $48.6 \pm 2.1 \mathrm{~b}$ & $179.5 \pm 1.0 \mathrm{ab}$ & $64.5 \pm 4.2$ & $67.9 \pm 4.4 \mathrm{~b}$ \\
\hline
\end{tabular}

$a, b, \ldots$ indicate significant differences among the values of the same thermal property.

* Values for extruded EVOH films from Aucejo et al. (1999) and López-Rubio et al. (2007).

\subsection{Barrier Properties}

Due to the hydrophilic nature of $\mathrm{EVOH}$, its barrier properties are dependent on the surrounding relative humidity conditions. For this reason, tests were carried out at $35 \% \mathrm{RH}$ and $90 \% \mathrm{RH}$. Figure 4.3 shows the values of permeability to water vapour $\left(\mathrm{P}_{\mathrm{H} 2 \mathrm{O}}\right)$ and oxygen $\left(\mathrm{P}_{\mathrm{O} 2}\right)$ for all the films studied.

\subsubsection{Water vapor permeability}


As expected, humidity is the most relevant factor in permeability values (López de Dicastillo et al., 2010; Aucejo et al., 2000, Zhang et al., 2001). In all cases, $P_{\mathrm{H} 2 \mathrm{O}}$ values increase by a factor between 10 and 100 when the relative humidity increases from 35 to $90 \%$. Compared to the extruded EVOH films, all films obtained by casting had higher water permeability values. The more deficient crystalline structure of the casting films (as shown by DSC studies) could be responsible for this effect.

In general, the addition of antioxidants increased the permeability of EVOH films. At $35 \% \mathrm{RH}$, the incorporation of ferulic acid, quercetin, or green tea extract yield an increase of about $20 \%$ on $\mathrm{P}_{\mathrm{H} 2 \mathrm{O}}$ values, probably caused by the presence of foreign substances in the polymer matrix.

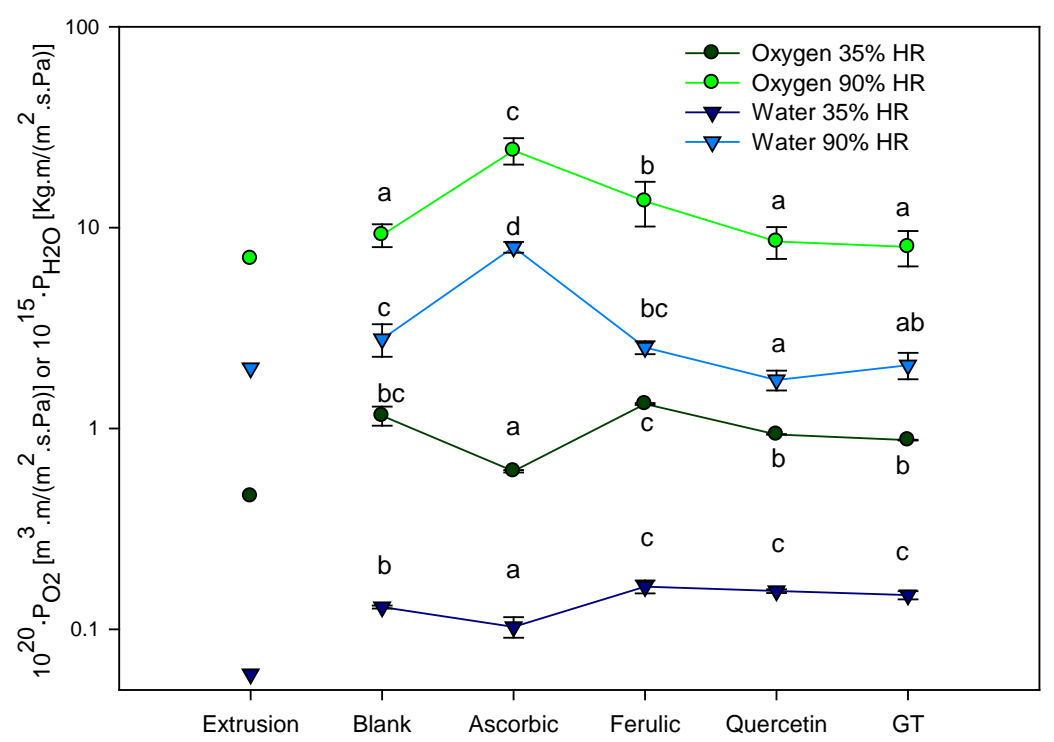

Figure 4.3. Oxygen and water vapour permeability values measured for the developed materials at 35 and 90\% RH, and reported for extruded EVOH (Aucejo, 2000; and Zhang et al., 2001). a, b, ... indicate significant differences among the values of the same thermal property.

On the other hand, the film with ascorbic acid produced an unexpected barrier improvement, which might be a consequence of interactions between the acid 
and the hydroxyl groups of the polymer. At high relative humidity (90\%), the addition of quercetin and green tea extract provided an improvement of the water barrier, attributable to the lower affinity of these agents for water, which may reduce the hydrophilic capacity of the composite matrix. The opposite observation was made for the film with ascorbic acid; the high affinity of the acid for water may result in its solubilization and the breakage of the interaction with polymer chains, resulting in a higher plasticization and the subsequent increase in $\mathrm{P}_{\mathrm{H} 2 \mathrm{O}}$ value.

\subsubsection{Oxygen permeability}

Figure 4.3 also presents the oxygen permeability values for the various materials at 35 and $90 \% \mathrm{RH}$. Again, the relative humidity is the most relevant factor on the oxygen permeability. The previously mentioned polymer plasticization caused by the ingress of water in the polymer matrix is responsible for this effect. The molecules of water reduce the interactions of hydrogen bonds between the hydroxyl groups of the polymer chains, also reducing the internal cohesion and increasing the flexibility of the material, and decreasing the barrier properties (Aucejo, 2000; Zhang et al., 2001; Yamamoto et al.,, 2009).

The comparison between the $\mathrm{P}_{\mathrm{O} 2}$ values of extruded and cast films revealed the same effect of processing as was observed for $\mathrm{P}_{\mathrm{H} 2 \mathrm{O}}$ values. Cast films had a more intense oxygen transport process, especially at 35\% $\mathrm{RH}$. The presence of residual solvent in the films and of a defective crystalline structure can be considered as the main causes of this behavior.

With respect to the influence of the incorporation of antioxidants, all films had similar $\mathrm{P}_{\mathrm{O} 2}$ values at $35 \% \mathrm{RH}$ with the exception of the film with ascorbic acid. This result is in agreement with that observed for the $\mathrm{P}_{\mathrm{H} 2 \mathrm{O}}$ values and may be caused by interactions between ascorbic acid and the polymeric segments. This effect vanished at high humidity, as also occurred in the water transmission process, with the sample containing ascorbic acid being the one with the highest $\mathrm{P}_{\mathrm{O} 2}$ value. 


\subsection{Antioxidant release from the films}

The main mechanism of action of the materials developed is through the release of the antioxidant compounds in the food product that is being protected. Therefore, the release of antioxidants from the films into different food simulants (water for aqueous foods, $10 \%$ ethanol for alcoholic beverages and $95 \%$ ethanol for fatty foods) was monitored at $37^{\circ} \mathrm{C}$.

As an example, Figure 4.4 shows the concentration of green tea extract in the various food simulants as a function of exposure time. All samples and simulants had an "exponential growth to a maximum" type of profile, although the extent and the kinetics of the release depended on the type of food simulants, and the antioxidant agent. Similar results were obtained in previous work on the release of active agents from materials obtained by extrusion (López de Dicastillo et al., 2010).

Despite the precautions taken in sample handling and storage, degradation of the ascorbic acid release from the EVOH films was observed in the aqueous simulants, hence making it difficult to monitor the accumulation of ascorbic acid in the various simulant liquids. Instead, the release of ascorbic acid from the films was monitored by measuring the amount of ascorbic acid remaining in the film by direct UV spectroscopy measurements.

Figure 4.5 shows the results obtained from films exposed to water and $10 \%$ ethanol. As can be seen, the presence of ascorbic acid in the film decreases exponentially to a minimum, indicating a release process similar to those observed for the other antioxidants.

It is also important to mention that ascorbic acid was protected from degradation within the polymer matrix as it was revealed by the constant UV absorbance observed in stored films. 


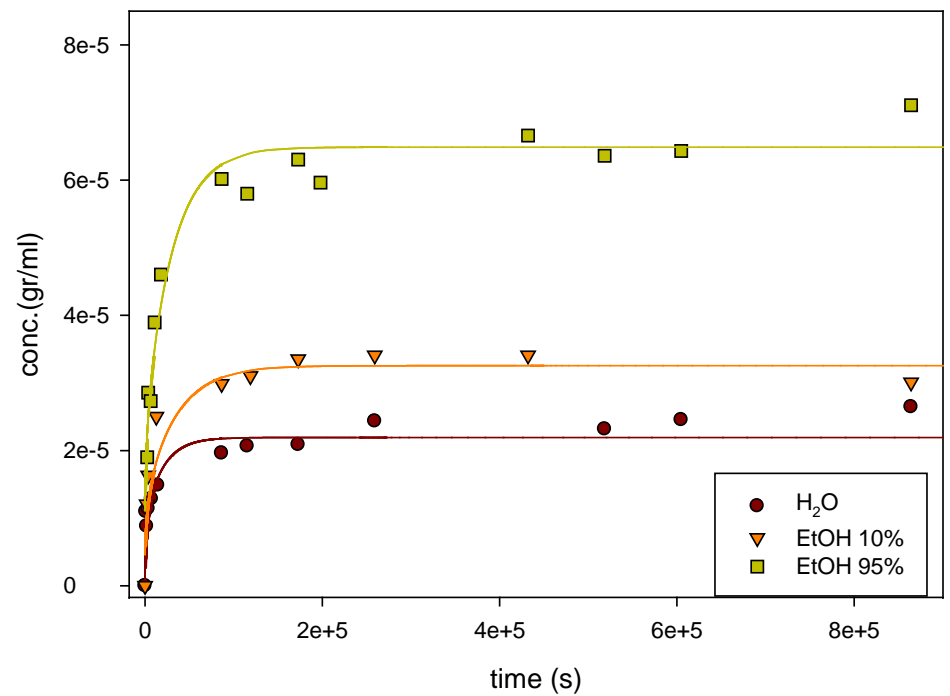

Figure 4.4. Experimental data and theoretical description of green tea extract release to different food simulants.

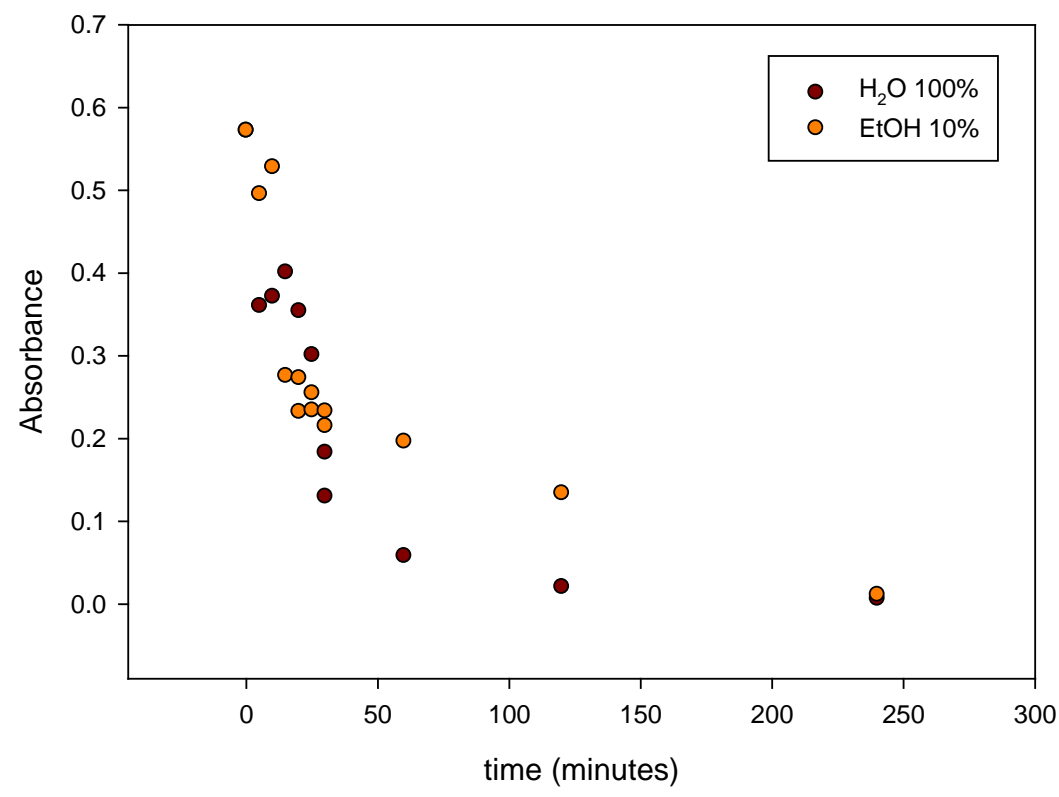

Figure 4.5. UV absorbance measured in films containing ascorbic acid as a function of the time exposed to the food simulants. 
A full characterization of a mass transport process requires the measurement of both its extent and its kinetics. The extent of release at equilibrium (after a prolonged exposure time) depends on the compatibility between the migrant and the simulant. In this work, it is assumed that the release process accomplished the following:

a) active agents are released by both sides of the film;

b) the extent of the release is controlled by an equilibrium which can be represented by the partition coefficient $(K)$ and represents the ratio between the concentration of agent in the film $\left(c_{p}\right)$ and in the simulant $\left(\mathrm{c}_{\mathrm{s}}\right)$ at equilibrium $K=\left(\mathrm{c}_{\mathrm{p}} / \mathrm{c}_{\mathrm{s}}\right)$;

c) the simulant medium is finite and the concentration of the active agent is homogenous.

The $K$ values for the diverse film/simulant systems are shown in Figure 4.6. As can be seen the extent of the release differs with the agent and simulant. Ascorbic acid was released to a large extent into water and $10 \%$ ethanol ( $K$ values ca. 100) thanks to its great solubility in water. In contrast, its release into ethanol $95 \%$ was restricted by a low solubility, with a $K$ value above 10000.
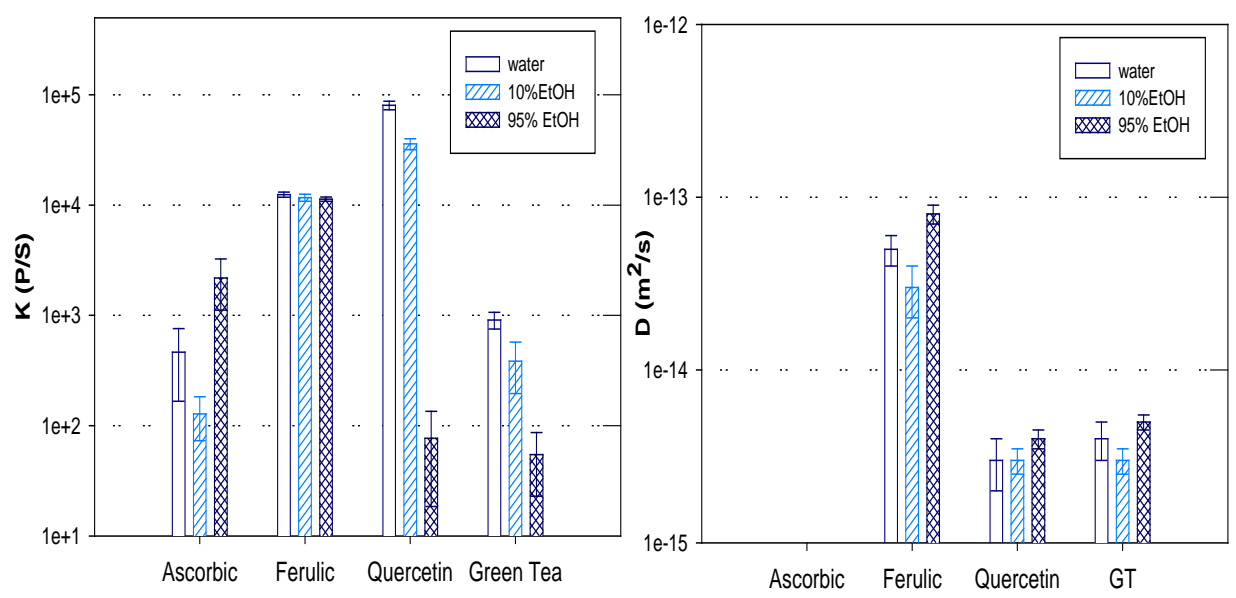
Figure 4.6. Partition $(K)$ and diffusion $(D)$ coefficient values for the release of ascorbic acid, ferulic acid, quercetin and green tea extract from EVOH-based materials into the food simulants tested.

The release of ferulic acid to the three simulants tested was very similar, with $K$ values ca. 10000 . This unexpected low delivery appears to be related to a chemical interaction with the polymer. As mentioned above, only one third of the agent extracted from the polymer showed antioxidant activity. Therefore, it can be assumed that a part of the agent was chemically bonded to the polymer and its release was not allowed. These linked molecules could be extracted under severe conditions (hot ethanol), although in a degraded form not showing antioxidant activity. In the release studies, however, bonded molecules are trapped and therefore do not participate in the mass transport process. In contrast, quercetin and green tea extract, antioxidants highly soluble in ethanol, were released to a great extent in $95 \%$ ethanol, approaching full extraction ( $K$ values $<50$ ). The low solubility of quercetin in water resulted in a highly restricted migration into aqueous simulants $(K>$ 10000). The presence of $10 \%$ alcohol slightly increased the release of quercetin and green tea extract. Green tea catechins are partially soluble in water, and therefore their release into water and 10\% ethanol was higher than that of quercetin.

To characterize the kinetics of the mass transport process within the film, it is necessary to solve Fick's laws considering the boundary conditions of the experiments. In this work, the presence of a partition equilibrium and a limited volume of simulant was considered. Also, the diffusion coefficient $(D)$ for the transport of the agent in the film is considered independent of time and position. By integration of the Fick's laws with these assumptions, the ratio of the mass of agent release into the simulant at time $t$ and at equilibrium $\mathrm{m}_{\mathrm{s}}{ }^{\mathrm{t}} / \mathrm{m}_{\mathrm{s}}{ }^{\dagger}$, can be expressed as:

$$
\frac{m_{S}^{t}}{m_{S}^{f}}=1-\sum_{n=1}^{\infty} \frac{2 \alpha(1+\alpha)}{1+\alpha+\alpha^{2} q_{n}^{2}} \exp \left(-4 D q_{n}^{2} t / \ell^{2}\right) ; \alpha=\frac{V_{S}}{K \cdot V_{P}}
$$


where $\alpha=V_{S} /\left(A V_{P}\right)$ and $q_{n}$ are the positive solutions of $\tan \left(q_{n}\right)=-\alpha \cdot q_{n}$ (Garde et al., 2001). $V_{S}, V_{P}$ and $\ell$ are the simulant volume and the film volume and thickness, respectively.

Since $\mathrm{EVOH}$ is a hydrophilic polymer which gets plasticized in contact with water or alcohols, the mass transport process and, specifically, the $D$ coefficient are dependent on the intake of these compounds. Thus, when the active film is immersed in the simulant, an intake of water (or alcohol) in the matrix occurs, which promotes a plasticization of the polymer and, subsequently, an increase in the $D$ value. Therefore, the assumption of a constant value for $D$ is apparently invalid. In a previous work, it was observed that the transport of large organic molecules through EVOH was so slow, compared to that of water or primary alcohols that, at the time that the polymer reaches equilibrium with the simulant, the release of the agent can be considered negligible. In this work, the observed release of antioxidant can be considered to occur from a "wet" polymer and the $D$ value measured corresponds to the plasticized film. Figure 4.4 includes the theoretical plots obtained for the release of green tea extract by equation (2) using the $K$ and $D$ values included in Figure 4.6. As can be seen, there is an excellent agreement between experimental data and theoretical curves.

The diffusivity of quercetin and green tea extract in $\mathrm{EVOH}$ showed values close to $3.10^{-15} \mathrm{~m}^{2} / \mathrm{s}$, similar in all the simulants. Values obtained on ethanolic simulant were slightly higher, showing a possibly higher plasticizing power of ethanol in this polymer matrix. $D$ values were slightly higher than those reported for quercetin from extruded EVOH (López de Dicastillo et al., 2010). The type of processing appears to be responsible for this difference.

The release kinetics of ferulic acid was very similar in all simulants, and faster than those observed for quercetin and green tea extract. Molecular diffusion takes place by statistical jumps within the free volume of the polymer amorphous region: the smaller and more flexible the diffusant substance is, the faster the process is. Thus, the smaller molecular size of ferulic acid, compared to the flavonoids (quercetin, catechin), is responsible for a faster 
process. No reliable $D$ values could be obtained for ascorbic acid owing to the previously mentioned degradation in the simulants and the large errors obtained in the measurement of average concentrations of ascorbic acid in films by direct spectroscopy tests on films.

Besides monitoring the release of the agent, it was considered important to confirm that the agents maintained their antioxidant activity. The antioxidant activity of the simulants exposed to the active films was determined using the method based on the reduction of the free radical DPPH: The antioxidant activity was observed to be proportional to the antioxidant concentration in the different simulants. Figure 4.7 presents the maximum antioxidant activity of the food simulants exposed to the antioxidant films, expressed as ascorbic acid equivalents for a better comparison between samples. In general these values were obtained at the end of the storage time, but for ascorbic acid this value was measured during the first stages of the exposure. These results refer to the antioxidant activity that a $1 \mathrm{~L}$ package made with these films would provide to the packaged product. In water and $10 \%$ ethanol simulants, films with ascorbic acid provided best results. The reason for this effect is the abovementioned higher solubility of this antioxidant in these liquid media.

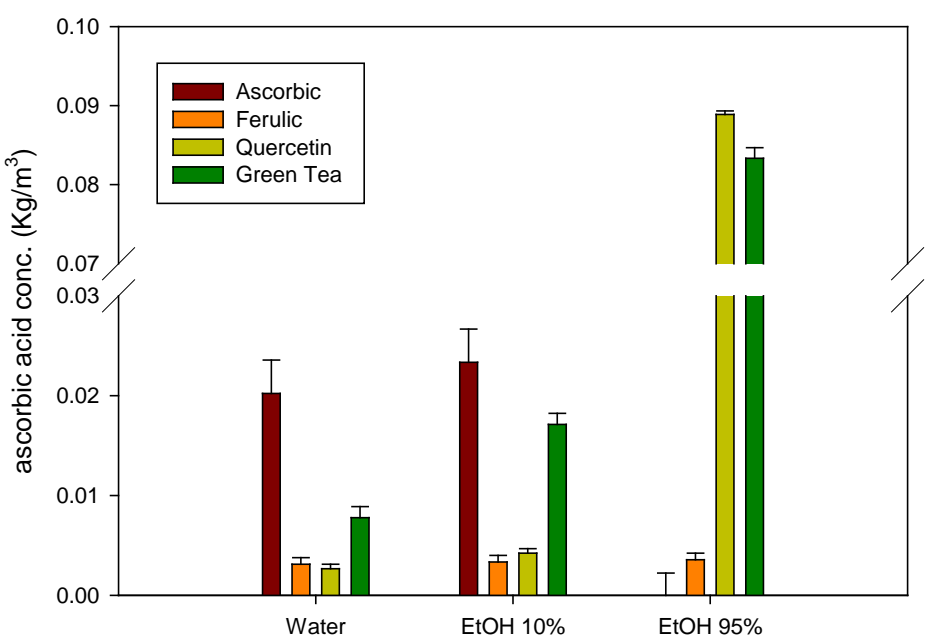

Figure 4.7. Maximum antioxidant activity, expressed as ascorbic acid concentration, in all food stimulants in contact with EVOH films containing acorbic acid, ferulic acid, quercetin and green tea extract. 
In 95\% ethanol, the highest activities were reached by the films with quercetin and green tea extract incorporated, because both types of films released most of the flavonoid incorporated. In general, green tea extract-containing materials presented better characteristics for the production of an all-purpose active package.

\subsection{Brined sardines packaging results}

Figures 4.8 and 4.9 show the evolution of the oxidation of the brined sardines packaged with the different active materials over the days, measured as peroxide and malondialdehyde index, respectively. The control sample shows that after three days, oxidation state had increased considerably. The oxidation was reduced in the sardines packaged with the active materials, especially in the case of the materials with green tea extract, whose release and antioxidant activity were high in aqueous simulants, and superior to ascorbic acid after 24 hours of contact.

The oxidation of the control sample did not increase markedly after the third day, and after five days peroxide concentration started to decrease till the end of the experiment, as a result of peroxide degradation due to secondary oxidation reactions (Labuza et al., 1971). The oxidation process was very fast owing to: i) sardines with highly unsaturated fat, because of the season (Beltran \& Moral, 1990); ii) salted process may induce prooxidation (Aubourg \& Ugliano, 2002; Guillén \& Ruiz, 2004).

Brined sardines in contact with materials containing quercetin and ferulic acid had a lower oxidation state than the control sample, but showed the same oxidation tendency, with a maximum at fifth day followed by a subsequent decrease. Nevertheless, peroxide degradation was delayed for these samples, compared to the control. This was an indication of the radical scavenging activity of the antioxidants from the active materials, that it was also indicated by a decrease in aldehyde accumulation, as Figure 4.9 shows. Films with green tea extract had similar behavior to these materials, but green tea extract 
was more efficient in the initial antioxidant activity preventing peroxide accumulation.

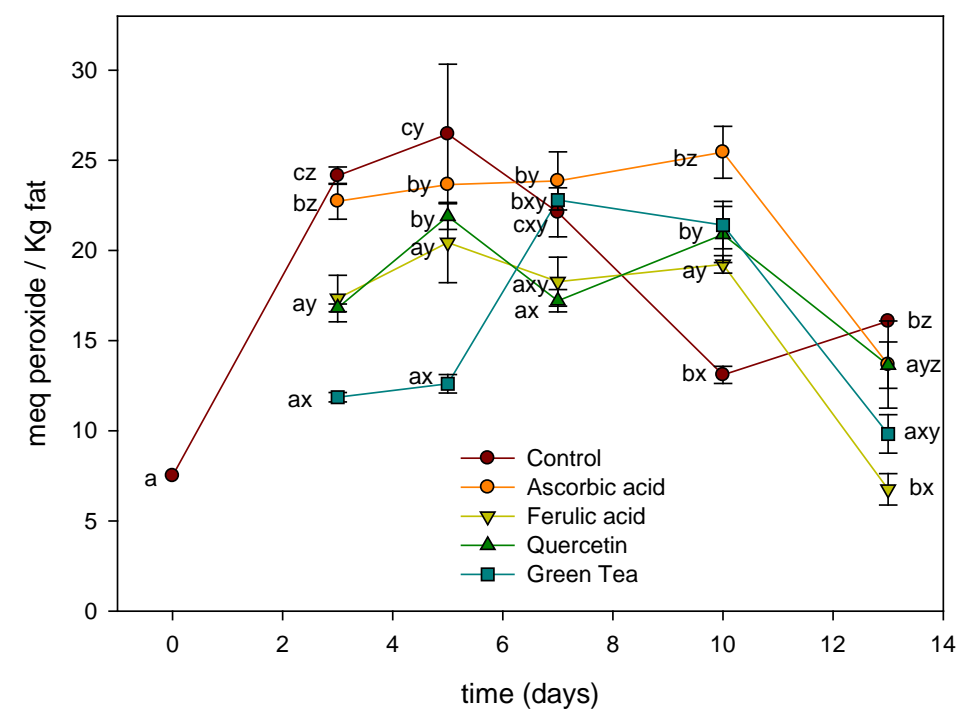

Figure 4.8. Evolution of sardines fat oxidation by measuring peroxide index.

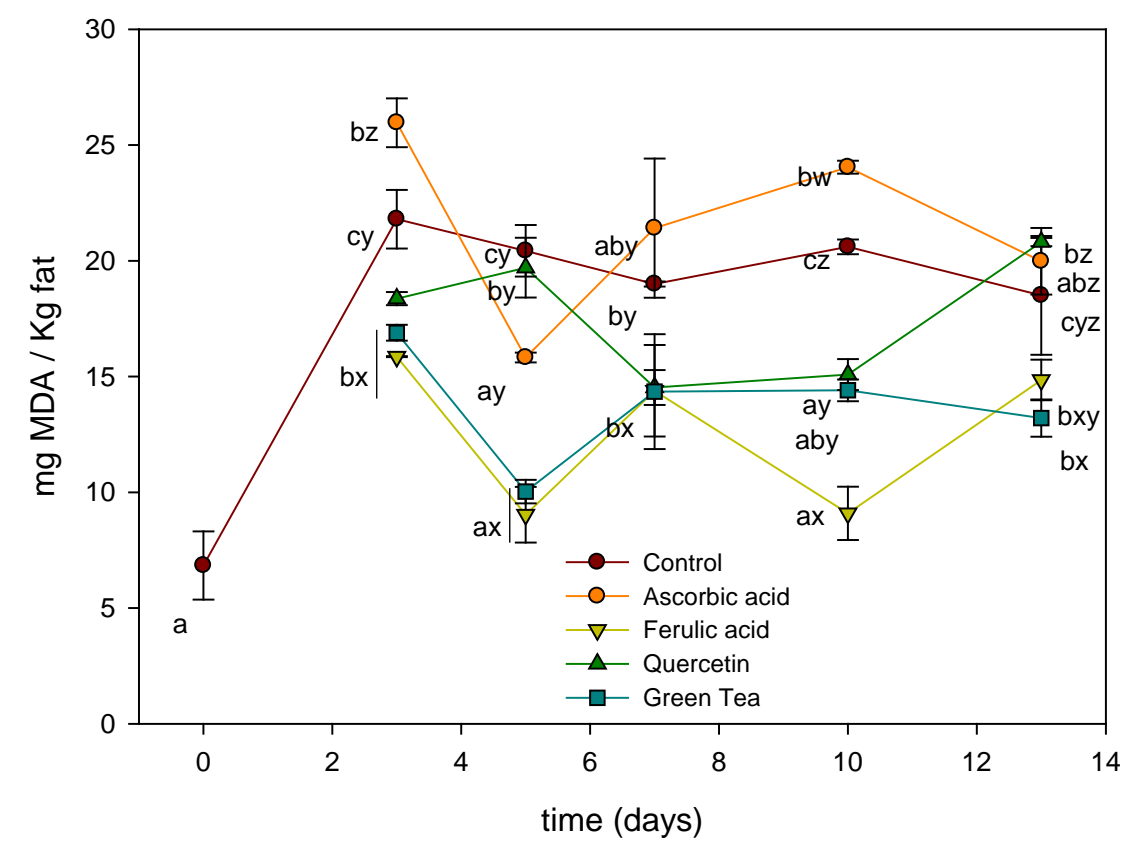

Figure 4.9. Sardines fat oxidation kinetic by measuring malonaldehyde content. 
However, after seven days of preservation, peroxide concentration increased sharply, but aldehyde presence was never as high as that of the control during the days of storage. The same occurred for the materials with ferulic acid and quercetin.

Materials with ascorbic acid had a completely different activity. Not only did they not prevent lipid oxidation but they also had some prooxidat effect, as the TBARS index showed on most of the days of experiment. Ascorbic acid is a known antioxidant commonly used in the food industry but it has also been associated with prooxidant actions (Chen et al., 2008). In relation to peroxide concentration, sardines with ascorbic acid material presented some protection at the first three days. These results are in good agreement with the release results of these materials that showed a fast release at the first days.

\section{CONCLUSIONS}

Antioxidant active films based on an ethylene-vinyl alcohol copolymer and natural antioxidants were successfully developed by casting. Thermal analysis revealed that the materials had a deterioration of the crystallinity structure, and approximately $4 \%$ of residual solvent, which resulted in a reduction in barrier properties compared to materials obtained by extrusion. The incorporation of antioxidants did not greatly affect the polymer properties, and in the case of materials containing green tea extract and quercetin permeability values even decreased. Release of active agents depended on the affinity of the antioxidants for the food simulants, the release of ascorbic and ferulic acid being higher in aqueous simulants, and the release of quercetin and green tea extract higher in ethanolic simulant.

The antioxidant activities of the films were tested against lipid oxidation of brined sardines. The films with green tea extract were the most effective, slowing down the peroxide values from 27 to $12 \mathrm{meq} / \mathrm{Kg}$ fat on the fifth day of storage, and also reducing the malonaldehyde concentration by $25 \%$ during the storage time. 


\section{ACKNOWLEDGEMENTS}

The authors acknowledge the financial support of the Spanish Ministry of Science and Innovation, projects AGL2006-02176, AGL2009-08776 and Fun-

C-Food CSD2007-00063, and the C. L-d-D fellowship (FPU program). Karel

Clapshaw provided assistance with the English language text

\section{REFERENCES}

Aubourg, S. P., \& Ugliano, M. (2002). Effect of brine pre-treatment on lipid stability of frozen horse mackerel (Trachurus trachurus). European Food Research and Technology, 215, 91-95.

Aucejo, V. S., Catalá, R., \& Gavara, R. (2000). Interactions between water and EVOH food packaging films, Food Science and Technology International, 6, 159-164.

Aucejo, S., Marco, C., \& Gavara, R. (1999). Water effect on the morphology of EVOH copolymers. Journal of Applied Polymer Science, 74, 1201-1206.

Aucejo, S. Study and characterization of the humidity effect on the barrier properties of hydrophilic polymeric structures. Ph.D. Dissertation 2000, Univ. Valencia (Spain).

Beltran, A., \& Moral, A. (1990). Influencia de las variaciones estacionales sobre la composicion de la fraccion lipidica de sardine (Sardina pilchardus W.). Grasas y aceites, 41, 73-81.

Bligh, E. G., \& Dyer, W. J. (1959). A rapid method of total lipid extraction and purification. Canadian Journal of Biochemistry and Physiology, 37, 911-917.

Botsoglou, N. A., Fletouris, D. J., Papageorgiu, G. E., Vassilopoulos, V. N., Mantis, A. J., \& Trakatellis, A. G. (1994). Rapid, sensitive and specific thiobarbituric acid method for measuring lipid peroxidation in animal tissue, food and feedstuff samples. Journal of Agricultural and Food Chemistry, 42, 1931-1937.

Chen, Q., Espey, M. G., Sun, A. Y., Pooput, C., Kirk, K. L., Krishna, M. C., Khosh, D. B., Drisko, J., Levine, M. (2008). Pharmacologic doses of ascorbate act as a prooxidant and decrease growth of aggressive tumor xenografts in mice. Proceedings of the National Academy of Sciences of the United Stated of America, 105, 11105-11109.

Garces, O., Nerin, C., Beltran, J.A., Roncales, P. (2003). Antioxidant active varnish. European Patent EP1477159-A1.

Garde, J. A., Catalá, R., Gavara, R., \& Hernández R. J. (2001). Characterizing the migration of antioxidants from polypropylene into fatty simulants. Food Additives and Contaminants, 18, 750-762. 
Gemili, S., Yemenicioglu A., Altinkaya S. A. (2010). Development of antioxidant food packaging materials with controlled release properties. Journal of Food Engineering, 96, 325-332.

Giménez, B., Gómez-Guillén, M. C., Pérez-Mateos, M., Montero, P., \& Márquez-Ruiz, G. (2011). Evaluation of lipid oxidation in horse Mackerel patties covered with borage-containing film during frozen storage. Food Chemistry, 124, 1393-1403.

Giménez, B., Roncalés, P., \& Beltrán, J. A. (2005). The effects of natural antioxidants and lighting conditions on the quality characteristics of salmon (Salmo salar) packaged in modified atmosphere. Journal of the Science of Food and Agriculture, 85, 1033-1040.

Gómez-Estaca, J., Bravo, L., Gómez-Guillen, M. C., \& Montero, P. (2009). Antioxidant properties of tuna-skin and bovine-hide gelatin films induced by the addition of oregano and Rosemary extracts. Food Chemistry, 112, 18-25.

Gómez-Estaca, J., Montero, P., Giménez, B., \& Gómez-Guillen, M. C. (2007). Effect of functional edible films and high pressure processing on microbiologic and oxidative spoilage in cold-smoked sardine (Sardina pilchardus). Food Chemistry, 105, 511520.

Granda-Restrepo, D. M., Soto-Valdez, H., Peralta, E., Troncoso-Rojas, R., \& GracianoVerdugo, A. Z. (2009). Migration of $\alpha$-tocopherol from an active multilayer film into whole milk poder. Food Research International, 42, 1396-1402.

Guillén, M. D., \& Ruiz, A. (2004). Study of the oxidative stability of salted and unsalted salmon fillets by $1 \mathrm{H}$ nuclear magnetic resonance. Food Chemistry, 86, 297-304.

ISO 2528:1995 Sheet materials - Determination of water vapor transmission rate Gravimetric (dish) method.

Jung, D. C., Lee, S. Y., Yoon, J. H., Hong, K. P., Kang, Y. S., Park, S. R., Park, S. K., Ha, S. D., Kim, G. H., \& Bae, D. H. (2009). Inhibition of pork and fish oxidation by a novel plastic film coated with horseradish extract. Food Science and Technology, 42, 856-861.

Labuza, T. P., Heidelba, N. D., \& Silver, M. (1971). Oxidation at intermediate moisture contents. Journal of the American Oil Chemists Society, 48, 86-90.

López de Dicastillo, C., Alonso, J. M., Catalá, R., Gavara, R., \& Hernández-Muñoz, P. (2010). Improving the antioxidant protection of packaged food by incorporating natural flavonoids into ethylene-vinyl alcohol copolymer (EVOH) films. Journal of Agricultural and Food Chemistry.

López-de-Dicastillo, C., Gallur, M., Catalá, R., Gavara, R., Hernández-Muñoz, P. (2010). Immobilization of $\beta$-cyclodextrin in ethylene-vinyl alcohol copolymer for active food packaging applications. Journal of Membrane Science, 353, 184-191 
López-de-Dicastillo, C., Catalá, R., Gavara, R., Hernández-Muñoz, P. (2011). Food applications of active packaging EVOH films containing cyclodextrins for the preferential scavenging of undesirable compounds. Journal of Food Engineering, in press.

López-Rubio, A., Lagarón, J. M., Yamamoto, T., \& Gavara, R. (2007). Radiationinduced oxygen scavenging activity in $\mathrm{EVOH}$ copolymers. Journal of Applied Polymer Science, 105, 2676-2682.

López-Rubio, A., Almenar, E., Hernández-Muñoz, P., Lagarón, Catalá, R., \& Gavara, R. (2004). Overview of active polymer-based packaging technologies for food applications. Food Reviews International, 20, 357-387.

Nerin, C., Tovar, L., Djenane, D., Camo, J., Salafranca, J., Beltran, J.A., Roncales, P. (2006). Stabilization of beef meat by a new active packaging containing natural antioxidants. Journal of Agricultural and Food Chemistry, 54, 7840-7846

Okada, Y., \& Okada, M. (1998). Scavenging effect of water soluble proteins in broad beans on free radicals and active oxygen species. Journal of Agricultural and Food Chemistry, 46, 401-406.

Pereira de Abreu, D. A., Paseiro Losada, P., Maroto, J., \& Cruz, J. M. (2010). Evaluation of the effectiveness of a new packaging film containing natural antioxidants (from barley husks) that retard lipid damage in frozen Atlantic salmon (Salmo salar L.). Food Research International, 43, 1277-1282.

Serdaroglu, M., \& Felekoglu, E. (2003). Effects of using rosemary extract and onion juice on oxidative stability of sardine (Sardina pilchardus) mince. Journal of Food Quality, 28, 109-120.

Torres-Arreola, W., Soto-Valdez, H., Peralta, E., Cardenas-Lopez, J. L., \& EzquerraBrauer, J. M. (2007). Effect of low density polyethylene film containing butylated hydroxytoluene on lipid oxidation and protein quality of Sierra fish (Scomberomorus sierra) muscle during frozen storage. Journal of Agricultural and Food Chemistry, $55,6140-6146$.

UNE Standard No. 55-023-73. Materias grasas [Fats]. Índice de Peróxidos [Peroxide index].

Vyncke, W. (1970). Direct determination of the thiobarbituric acid value in trichloroacetic acid extract of fish as a measure of oxidative rancidity. Fette Seifen Anstrichmittel, 72, 1084-1087.

Wessling, C., Nielsen, T., Leufvén, A., Jägerstad, M. (1998). Mobility of a-tocopherol and BHT in LDPE in contact with fatty food simulants. Food Additives and Contaminants, 15, 709-715.

Xu, T., Lei, H., Xie, C. H. (2003). The effect of nucleating agent on the crystalline morphology of polypropylene (PP). Materials and Design, 24, 227-230. 
Yamamoto, T., Kanda, T., Nishihara, Y., Ooshima, T., \& Saito, Y. (2009). Correlation study among oxygen permeability, molecular mobility, and amorphous structure change of poly (ethylene-vinylalcohol copolymers) by moisture. Journal of Polymer Science Part B: Polymer Physics, 47, 1181-1191.

Zhang, Z., Britt I. J., Tung M. A. (2001). Permeation of oxygen and water through EVOH films as influenced by relative humidity. Journal of applied polymer science, 82, 1866-1872. 


\subsection{DESARROLLO DE MATERIALES PARA EL CONTROL DE COMPUESTOS INDESEABLES EN ALIMENTOS}

Artículo 5: Immobilization of $\beta$-cyclodextrin in ethylene vinyl alcohol copolymer for active food packaging applications.

Artículo 6: Food applications of active packaging EVOH films containing cyclodextrins for the preferential scavenging of undesirable compounds.

Artículo 7: Development of active polyvinyl alcohol/ $\beta$-cyclodextrin composites to scavenge undesirable food components. 
Artículo 5

\section{IMMOBILIZATION OF $\beta$-CYCLODEXTRIN IN ETHYLENE- VINYL ALCOHOL COPOLYMER FOR ACTIVE FOOD PACKAGING APPLICATIONS}

Carol López-de-Dicastillo, Miriam Gallur, Ramón Catalá,

Rafael Gavara, Pilar Hernandez-Muñoz

Journal of Membrame Science 2010, 353, 184-191 


\section{ABSTRACT}

Current developments in active food packaging are focusing on incorporating agents into the polymeric package walls that will release or retain substances to improve the quality, safety and shelf-life of the food. Because cyclodextrins are able to form inclusion complexes with various compounds, they are of potential interest as agents to retain or scavenge substances in active packaging applications. In this study, $\beta$-cyclodextrin $(\beta C D)$ was successfully immobilized in an ethylene-vinyl alcohol copolymer with a $44 \%$ molar percentage of ethylene (EVOH44) by using regular extrusion with glycerol as an adjuvant. Films with $10 \%, 20 \%$ and $30 \%$ of $\beta C D$ were flexible and transparent. The presence of the agent slightly increased the glass transition temperature and the crystallinity percentage of the polymer, that is to say, it induced some fragility and a nucleating effect. The water vapor, oxygen and carbon dioxide barrier properties of the materials containing $\beta C D$ were determined and compared with those of the pure polymeric material. Permeability to these three permeants increased with the addition of $\beta C D$ due to the presence of discontinuities in the matrix and to the internal cavity of the oligosaccharide. Also the $\mathrm{CO}_{2} / \mathrm{O}_{2}$ permselectivity increased with the addition of $\beta C D$. Finally, the potential effect of the composites in the food aroma was analyzed. The materials with $\beta C D$ preferentially sorbed apolar compounds such as terpenes. This characteristic could be useful in active packaging applications for preferentially retaining undesired apolar food components like hexanal or cholesterol.

Keywords: $\beta$-cyclodextrin, EVOH copolymer, extrusion, immobilization, DSC, retention of organic compounds, gas permeation. 


\section{INTRODUCTION}

Active food packaging is one of the most dynamic emerging technologies that the food industry is investigating as an alternative to traditional food techniques (intense heat treatments, salting, acidification, drying, chemical preservation, etc.) for several uses, especially combined with other technologies such as MAP, radiation, pulsed electric fields, high pressure treatments, etc (Vermeiren et al., 1999). Active food packaging is defined as the technology in which the packaging system plays an active role in food preservation and quality during the marketing process. Examples of active packaging technologies include the use of oxygen scavengers, carbon dioxide or ethylene emitters and scavengers, ethanol releasers, amine or aldehyde scavengers, and antimicrobial or antioxidant agents.

In many present-day active packaging technologies the active agent is placed in the package with the food, in a small sachet, pad or device manufactured from a permeable material which allows the active compound to achieve its purpose but prevents direct contact with the food product, protecting the food from contamination or degradation. Active packaging developments are now focusing on incorporating the agents into the polymeric matrices which constitute the package walls; the resulting materials act by releasing substances which have a positive effect on the food or by retaining undesired substances from the food or the internal atmosphere of the package.

Because cyclodextrins (CDs) are able to form inclusion complexes with various compounds, they present a potential interest as agents to retain or scavenge substances such as odors, bitter compounds, lactose, cholesterol, etc., or to add aromas, colors, or functional ingredients whose release could enhance the quality of the packaged product and extend its shelf-life.

Cyclodextrins (CDs) are cyclic oligosaccharides composed of several glucose units ( 6 units in $\alpha C D, 7$ units in $\beta C D$ or 8 units in $\gamma C D$ ) linked by $\alpha-(1-4)$ bonds, with a ring structure characterized by an hydrophilic external surface and an hydrophobic cavity. This unique structure enables CDs to form inclusion 
complexes, entrapping all or part of a 'guest' molecule inside their cavities. In aqueous solution, this hydrophobic cavity contains about 3 ( $\alpha C D), 7$ ( $\beta C D)$ or 9 ( $y C D$ ) poorly held and easily displaceable water molecules (Sabadini et al., 2006). The cyclodextrin molecules may bind suitably-sized non-polar aliphatic and aromatic compounds such as aroma compounds and lipophilic drugs.

$\beta C D$, the seven-glucose cyclic oligosaccharide, is nontoxic, edible (on the GRAS list since 1992), nonhygroscopic, chemically stable and easy to separate, and overall is readily available at a low cost. This cyclodextrin has a wide range of applications in the food and pharmaceutical industries. Food ingredients, bioactive compounds, or flavor compounds can be complexed by $\mathrm{CDs}$ to protect them against oxidation, light-induced reactions, heat-promoted decomposition, loss by volatility, or sublimation, or to reduce undesired tastes/odours (Reineccius et al., 2002; Szente and Szejtli, 2004). Empty $\beta C D$ is also being used in the food industry to entrap or remove undesirable compounds such as bitter components from coffee and tea (Yu, 1988), milk casein hydrolysate (Specht et al., 1981), ginseng extract (Akiyama and Miyao, 1979), or grapefruit or mandarin juices (Shaw and Wilson, 1983). Reducing the cholesterol in food is probably the main commercial use of $\beta C D$ in the food sector (Comini and Mentink, 1994).

Several applications have been described in which cyclodextrins or cyclodextrin derivatives have been immobilized in different polymeric supports. Cyclodextrins have been immobilized in polyvinyl alcohol based membranes for pervaporation of alcohol/water mixtures (Yamasaki et al., 1994), and enantiomer separation and sorption of xylene (Touil et al., 2008). The same objective was pursued in the preparation of polyacrylic acid membranes containing diverse cyclodextrines (Kusumocahyo et al., 2004). The surface of cellulose membranes were modified by covalent bonding of $\beta C D$ for chiral separation of tryptophan (Xiao and Chung, 2007). Membranes for pervaporation of benzene/cyclohexane were prepared by synthesis of a polyurethane copolymer containing cyclodextrins (Lue and Peng, 2003). Most of these membranes were prepared by solution/casting and diverse 
crosslinking agents were added to immobilize the oligosaccharides. Modified cyclodextrins with different substituents (hydroxyl, acetyl, silanes...) to improve polymer compatibility have been used to increase water permeability and reduce migration in extruded polyethylene and polypropylene films (Wood and Beaverson, 1996).

In this study, $\beta C D$ was immobilized in an ethylene-vinyl alcohol copolymer and the resulting materials were studied for their potential use in active packaging. Ethylene-vinyl alcohol copolymers (EVOHs) are a family of semicrystalline random copolymers widely used in the food-packaging sector due to their outstanding properties as gas barriers to oxygen and organic compounds (solvents and food aromas), as well as their considerable chemical resistance and high transparency (Sanchez-Chaves et al., 2007). This family of materials has been also used in the preparation of membranes for solute release induced by water sorption (Hopfenberg et al., 1981). The major drawback of these materials in this application is their moisture sensitivity, which causes a significant decrease in their gas barrier properties. Nevertheless, this water sensitivity can be useful in the development of active packages for food, as food humidity is a potential mechanism to trigger their activity. EVOH was selected as the vehicle for immobilizing $\beta C D$ because of its hydrophilicity and polarity. EVOH should present good chemical compatibility with the external surface of the cyclodextrin molecule and the interior can be used to design active packages based on the release of complexed agents or the retention of undesirable food components.

In this study, EVOH films containing $\beta C D$ were prepared by conventional extrusion and the resulting materials were studied in order to characterize the effect of cyclodextrin addition on the most relevant properties of EVOH as a packaging material, namely its morphological, thermal and barrier properties. 


\section{MATERIALS AND METHODS}

\subsection{Chemicals and Reagents}

Ethylene vinyl alcohol copolymer with a $44 \%$ ethylene molar content (EVOH44) was gently supplied by The Nippon Synthetic Chemical Company, (Osaka, Japan). Reagent-grade ethanol, $\alpha$-pinene, d-limonene, linalool, citral, ethyl caproate, 2-nonanone, octanal, methyl-isobuthyl ketone, n-hexanal, nhexanol, silica gel, magnesium chloride $\mathrm{MgCl}_{2} \cdot 6 \mathrm{H}_{2} \mathrm{O}$, magnesium nitrate $\mathrm{Mg}\left(\mathrm{NO}_{3}\right)_{2} \cdot 6 \mathrm{H}_{2} \mathrm{O}$, sodium nitrite $\mathrm{NaNO}_{2}$, and sodium chloride $\mathrm{NaCl}$ were provided by Sigma (Madrid, Spain). Nitrogen, carbon dioxide and oxygen were provided by Abelló-Linde (Valencia, Spain)

$\beta C D$ was purchased from Wacker Fine Chemicals, S.L.(Barcelona) and glycerol from Sigma (Madrid). Water was obtained from a Milli-Q Plus purification system (Millipore, Molsheim, France).

\subsection{Film Preparation}

EVOH films containing $\beta C D$ were obtained by two methods: flat extrusion and compression molding. In both methods, films of the hydrophilic EVOH44 material containing different concentrations of cyclodextrins $(10,20$ and 30 nominal \%) were prepared. Previous thermal gravimetric analysis (not shown) revealed that thermal degradation of the pure compounds starts at very high temperatures, $330^{\circ} \mathrm{C}$ for $\beta \mathrm{CD}$ and $340^{\circ} \mathrm{C}$ for $\mathrm{EVOH}$.

For the flat extrusion process, a glycerol-CD paste was prepared, mixed with the polymer pellets and melt-blended during extrusion. The mixture of the three components was extruded on a Brabender DSE 20/40 co-rotating twin screw extruder (Plastograph, Dusseldorf, Germany) with a screw speed of 100 rpm and with the following thermal profile: $160,180,200,190$ and $190{ }^{\circ} \mathrm{C}$ at the flat die. The resulting films were ca. 50 micrometers thick, although the thickness of every sample was individually measured with a digital Mitutoyo micrometer (Metrotec, San Sebastian, Spain) in ten positions of the measured surface before testing. 
For the compression molding process, the EVOH polymer was ground with a knife mill and sieved, then mixed with the cyclodextrin powder and compression-molded in a hot plate Carver press (Carver, Wabash, IN, USA) at $190{ }^{\circ} \mathrm{C}$, and 20 bars for 1 minute, then the pressure was increased to 200 bars. After a total of 4 minutes, the material was cooled for 2 minutes at $20^{\circ} \mathrm{C}$. The films obtained were ca. 100 micrometers thick.

The film samples were vacuum-packed in aluminum/LDPE bags and stored at room temperature until the moment of analysis. The morphology of the composite, the degree of immobilization of $\beta C D$, the thermal properties, the oxygen, carbon dioxide and water vapor barrier properties and organic compound sorption were studied.

\subsection{Morphology}

The materials were analyzed by Electronic Scanning Microscopy (SEM), using a Hitachi model S-4100 with a BSE AUTRATA detector and EMIP 3.0 image trapping. After being completely dried, the samples were broken up to investigate their cross-section. A cylindrical aluminum stub cut like a straightbacked chair, on which the film was fixed using a double-sided copper tape, was used in a specific way to observe the morphology of the cross section. The stubs holding the films were then coated with gold.

\subsection{Immobilization studies}

Since cyclodextrins are partially water soluble and the first objective is to use the material for active food packaging, a preliminary study of cyclodextrin release from the films was carried out by determining the global migration from the polymer into water, as an aqueous food simulant, following EU regulations (UNE-EN 1186-3) with slight modifications (Grob et al., 2006; Grob et al., 2007). In brief, $4 \mathrm{~cm}^{2}$ samples of each of the films obtained were immersed in $100 \mathrm{~mL}$ of freshly distilled Millipore water for periods of 1 and 10 days at $40^{\circ} \mathrm{C}$ and the global migration values were determined on days 1 and 10 by calculating the weight loss according to the method prescribed in the 
applicable EC directives (European Economic Community, 1989, 1990; Garde et al., 1998). All the samples were measured in triplicate.

\subsection{Thermal Analysis}

Thermal properties were determined with a DSC Model Q2000 from TA Instruments (New Castle, DE, EEUU). Thermograms were obtained from -50 ${ }^{\circ} \mathrm{C}$ to $250{ }^{\circ} \mathrm{C}$ with a $10{ }^{\circ} \mathrm{C} / \mathrm{min}$ heating ramp. The glass transition and melting point temperature and enthalpy were calculated. The melting enthalpy values were corrected to the polymer weight and are expressed in $\mathrm{J} / \mathrm{g}$ of EVOH.

\subsection{Transport Properties}

\subsubsection{Water vapor}

WVP tests were carried out at 35, 50, 65, 75 and $100 \% \mathrm{RH}$ and $23{ }^{\circ} \mathrm{C}$ using permeability cups (Elcometer, Manchester, UK) according to ISO 2528 (ISO2528:1995, 1995). Aluminum cups were filled with $7 \mathrm{~g}$ of silica gel and sealed with vacuum silicon grease (Sigma, Barcelona, Spain) and the film to be tested. The film was fixed with a flat Viton ring, an aluminum ring and three press-screws. The cups were then stored in desiccators containing saturated salt solutions to ensure the required relative humidity: magnesium chloride $\mathrm{MgCl}_{2} \cdot 6 \mathrm{H}_{2} \mathrm{O}$, magnesium nitrate $\mathrm{Mg}\left(\mathrm{NO}_{3}\right)_{2} \cdot 6 \mathrm{H}_{2} \mathrm{O}$, sodium nitrite $\mathrm{NaNO}_{2}$, sodium chloride $\mathrm{NaCl}$ and water for humidities of 35, 50, 65, 75 and $100 \%$ respectively. The cups were weighed daily, and the plot of the weight increment over time provided the water vapor transmission rate. These values were divided by the water pressure gradient and multiplied by the sample thickness to obtain the water vapor permeability value. All the samples were measured in triplicate.

The water sorption of the prepared films was also measured. Film samples were cut, put on aluminum dishes and placed in the above mentioned desiccators. The samples were weighed daily until constant. The films were then dried for $48 \mathrm{~h}$ at $60^{\circ} \mathrm{C}$ under vacuum and weighed. The sorption values 
were calculated as the water gain per $100 \mathrm{~g}$ of dry sample. All the samples were measured in triplicate.

\subsubsection{Oxygen}

The oxygen permeation rates of the materials were determined at 50 and $90 \%$ $\mathrm{RH}$ and $23{ }^{\circ} \mathrm{C}$ using a OXTRAN Model 2/21 ML Mocon (Lippke, Neuwied, Germany). The film samples were first conditioned at the $\mathrm{RH}$ of the experiment in the desiccators described above. Two identical samples were then placed in the apparatus for analysis. The samples were conditioned in the cells for 6 hours, then the transmission values were determined every $45 \mathrm{~min}$. After the permeation tests were completed, continuous permeation experiments were carried out on each sample to determine the diffusion coefficient (D). From the transmission rate values measured during the transient state, the value of $D$ was assessed from the solution to Fick's second law for the boundary conditions of an isostatic permeation experiment (Gavara and Hernández, 1993).

\subsubsection{Carbon dioxide}

The carbon dioxide permeation rates of the materials were determined at 50 and $90 \% \mathrm{RH}$ and $23{ }^{\circ} \mathrm{C}$ using an isostatic permeation test (Gavara et al., 1996). In brief: a stainless-steel cell with two chambers separated by the film to be tested was used. A constant gas stream was passed through each chamber. The permeant gas, carbon dioxide, flowed through the upper chamber while the carrier gas, nitrogen, flowed through the lower chamber at the required relative humidity and drove the permeated molecules to the detector system.

To humidify the gases, a stream of gas was bubbled through a gas washing bottle filled with water and then mixed with a second stream of dry gas. Flowmeters (Dakota Instruments, Orangeburg, USA), needle valves (Swagelok, Solon $\mathrm{OH}, \mathrm{USA}$ ), and digital hygrometers were used to adjust and control the gas streams. At the exit from the lower chamber, the flowrate of carrier gas was measured by a mass flowmeter (Dakota Instruments, 
Orangeburg, USA). The concentration of $\mathrm{CO}_{2}$ in this stream was analyzed by gas chromatography. A HP5890 gas chromatograph (Agilent Technologies, Barcelona, SPAIN) equipped with a manual injection valve and an injection loop of $500 \mu \mathrm{L}$, a Chromosorb 102, 80/100 mesh, 12'x 1/8' column (Teknokroma, Barcelona, Spain), and a thermal conductivity detector was used. The GC was calibrated by injecting known amounts of carbon dioxide $\left(\mathrm{CO}_{2} \%=2.59 \cdot 10^{-4} \times\right.$ Peak area, $\left.\mathrm{r}^{2}=0.9993\right)$. Once the cell had been assembled, the carrier gas was passed through both chambers for at least 6 hours to remove all gases present in the cell during handling and equilibrate the film to the humidity of the test. At time zero, the permeant gas started to flow into the upper chamber. The concentration of carbon dioxide in the lower chamber was monitored until constant, that is to say, until the stationary state was established. The gas permeability $(P)$ was calculated as follows:

$$
P=\frac{C_{\mathrm{CO} 2} \cdot f \cdot \ell}{A \cdot \Delta p}
$$

Where $\mathrm{C}_{\mathrm{CO} 2}$ is the volume concentration of $\mathrm{CO}_{2}$ in the stationary state, $\mathrm{f}$ is the carrier gas flow in $\mathrm{m}^{3} / \mathrm{s}, \ell$ is the film thickness in $\mathrm{m}, \mathrm{A}$ is the film area in $\mathrm{m}^{2}$, and $\Delta \mathrm{p}$ is the difference in the partial pressure of $\mathrm{CO}_{2}$ in the stationary state between the two chambers, measured in $\mathrm{Pa}$.

\subsection{Sorption of organic compounds}

The organic compound retention capacity of the films and the effect of the addition of $\beta C D$ were also studied. A hydroalcoholic solution (5\% ethanol) of several organic compounds commonly found in food aromas was prepared at an initial concentration of $200 \mathrm{ppm}(\mathrm{mg} / \mathrm{L})$. The organic compounds selected were $\alpha$-pinene, $\mathrm{d}$-limonene, linalool, citral, ethyl caproate, 2-nonanone, octanal, methyl-isobuthyl ketone, n-hexanal and n-hexanol. The solution was then further diluted (to $5 \mathrm{ppm}$ ) with distilled water. The $\beta \mathrm{CD}$ and the EVOHbased film materials were exposed to this solution as follows: 
a) To determine the preferential sorption of the $\beta C D, 1 \mathrm{~g}$ of cyclodextrin was added to $30 \mathrm{~mL}$ of the same solution. The vial was closed with a PTFE/rubber septum and stored at room temperature for 15 days with constant stirring. The concentration of $\beta C D$ exceeded the molar concentration of the different compounds by a factor of 500 .

b) To determine the sorption capacity of the films, 10 pieces measuring $2 \mathrm{~cm} x$ $2 \mathrm{~cm}$, separated by glass rings, were threaded onto a stainless steel wire, immersed in $30 \mathrm{~mL}$ of distilled water and stored for 1 day at $40^{\circ} \mathrm{C}$ to remove all releasable $\beta C D$ molecules from the samples. Then, the threaded samples were removed from the vial, thoroughly rinsed with water, dried for 48 hours under vacuum and immersed in $30 \mathrm{~mL}$ of a $5 \mathrm{ppm}$ solution of hexanal, $\mathrm{d}$ limonene and $\alpha$-pinene, and stored for 15 days at room temperature. Parallel samples were prepared by dispersing $0.02 \mathrm{~g}$ of $\beta C D$ in $30 \mathrm{~mL}$ of the solution, which corresponds to the molar content of organic compounds in the sample and is similar to the $\beta C D$ content in the $E V O H-10 \beta C D$ sample. All the samples were prepared in triplicate.

The concentration of organic compounds present in the organic solution after the storage period was evaluated by gas chromatography. Three $5 \mathrm{~mL}$ fractions of the hydroalcoholic solution from each sample were placed in glass vials closed with PTFE/rubber septa. A Supelco 65- $\mu \mathrm{m}$ DVB/PDMS solid phase microextraction (SPME) fiber (Teknokroma, Barcelona, Spain) was exposed to the liquid solution for $10 \mathrm{~min}$ and immediately desorbed for $5 \mathrm{~min}$ in the injector of a HP5890 gas chromatograph (Agilent Technologies, Barcelona, Spain) equipped with a $30 \mathrm{~m}, 0.32 \mathrm{~mm}, 0.25 \mu \mathrm{m}$ TRB- 5 capillary column (Teknokroma, Barcelona, Spain). The chromatographic conditions were as follows: He as the carrier gas, 1/20 split injection, 210 and $300^{\circ} \mathrm{C}$ injector and detector temperatures, $5 \mathrm{~min}$ at $40^{\circ} \mathrm{C}$, first heating ramp to $60^{\circ} \mathrm{C}$ at $3^{\circ} \mathrm{C} / \mathrm{min}$, second heating ramp to $200{ }^{\circ} \mathrm{C}$ at $10{ }^{\circ} \mathrm{C} / \mathrm{min}$, and $5 \mathrm{~min}$ at $200{ }^{\circ} \mathrm{C}$. The gas chromatograph was calibrated by measuring hydroalcoholic solutions with known concentrations of the organic compounds. 


\subsection{Statistical analysis}

One-way analyses of variance were carried out. The SPSS ${ }^{\circledR}$ computer program (SPSS Inc., Chicago, IL, USA) was used. Differences in pairs of mean values were evaluated by the Tukey-b test for a confidence interval of $95 \%$.

\section{RESULTS AND DISCUSSION}

The objective of this work was to immobilize $\beta C D$ molecules in a $E V O H$ polymer matrix and produce films with functional characteristics suitable for the production of active packages for foods.

In a first attempt, EVOH powder was mixed with $\beta C D$ and films were obtained by compression molding at $190{ }^{\circ} \mathrm{C}$ and 20 bar for four minutes. The resulting films were translucent, brittle and heterogeneous, and the cyclodextrins were visible and concentrated in some areas due to an insufficient mixture of polymer chains and oligosaccharide molecules. Besides, the high migration results ruled out these materials for food packaging applications. Therefore, no further tests were done on the materials obtained by compression.

In the second procedure, the EVOH films were obtained by extrusion. To improve the $C D$ addition results, the CDs were first mixed with glycerol, then the resulting paste was manually mixed with the polymer pellets before being sent to the extruder hopper. The films obtained by this method were transparent and flexible, although some white spots could occasionally be observed due to the presence of $\beta C D$ aggregates. The final thickness was in the $50 \pm 10 \mu \mathrm{m}$ range. This technique was used to obtain materials with 10,20 and $30 \% \beta C D$ and $20 \%$ of glycerol, designated as EVOH-10ßCD, EVOH$20 \beta C D$ and EVOH-30ßCD, respectively. Blank samples of pure EVOH (EVOH) and $\mathrm{EVOH}$ with $20 \%$ of glycerol (EVOH-20G) were also extruded for comparison and submitted to the characterization and migration studies. 


\subsection{Morphological analysis}

The phase morphology of the prepared materials was studied through scanning electron microscopy. The cryo-fracture surface was examined after drying the samples; Figure 5.1 shows an example of the SEM images obtained. Figure 5.1A presents the morphology of the EVOH-20G sample used as control. As can be seen, the figure shows a continuous homogeneous matrix without phasing. Figure 5.1B is the SEM image of an extruded sample of EVOH with $30 \%$ of $\beta C D$ (EVOH-30ßCD). As can be seen, $\beta C D$ particles of different sizes (0.1-1.5 $\mu \mathrm{m})$ are dispersed within the polymer matrix, showing signs of low compatibility at the interface. Also, the image shows the presence of particle aggregates, which would explain the white spots observed in the films with the naked eye.

(A)

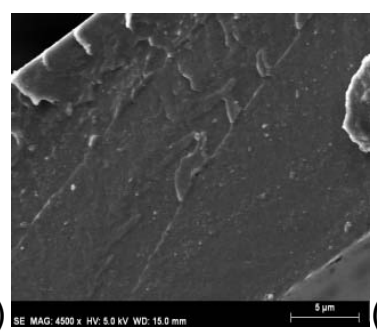

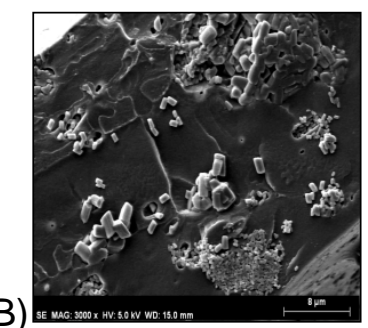

(C)

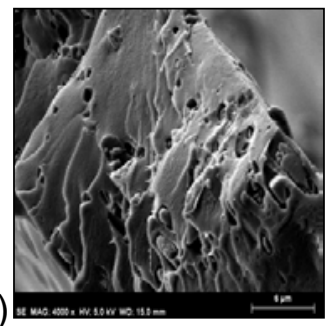

Figure 5.1. Cross-section SEM images of the materials: EVOH-20G (A), EVOH-30ßCD before migration process (B) and $\mathrm{EVOH}-30 \beta C D$ after migration (C).

Figure $5.1 \mathrm{C}$ is the image of a similar sample after immersion in water for 10 days. Small holes in the fracture surface and some small particles can be seen in this picture, as in Figure 5.1B. Nevertheless, in these samples there is no evidence of large particles or particle aggregates, which suggests that they may have been released into the liquid medium before the SEM analysis.

\subsection{Immobilization analysis}

Since cyclodextrins are partially water soluble and the first objective is to use them in an active food packaging material, a preliminary study of their release 
from the films was carried out by determining the global migration from the polymer into water, as an aqueous food simulant, in accordance with EU regulations (Garde et al., 1998; Grob et al., 2006; Grob et al., 2007). Film samples were immersed in distilled water and the global migration values were measured on days 1 and 10 .

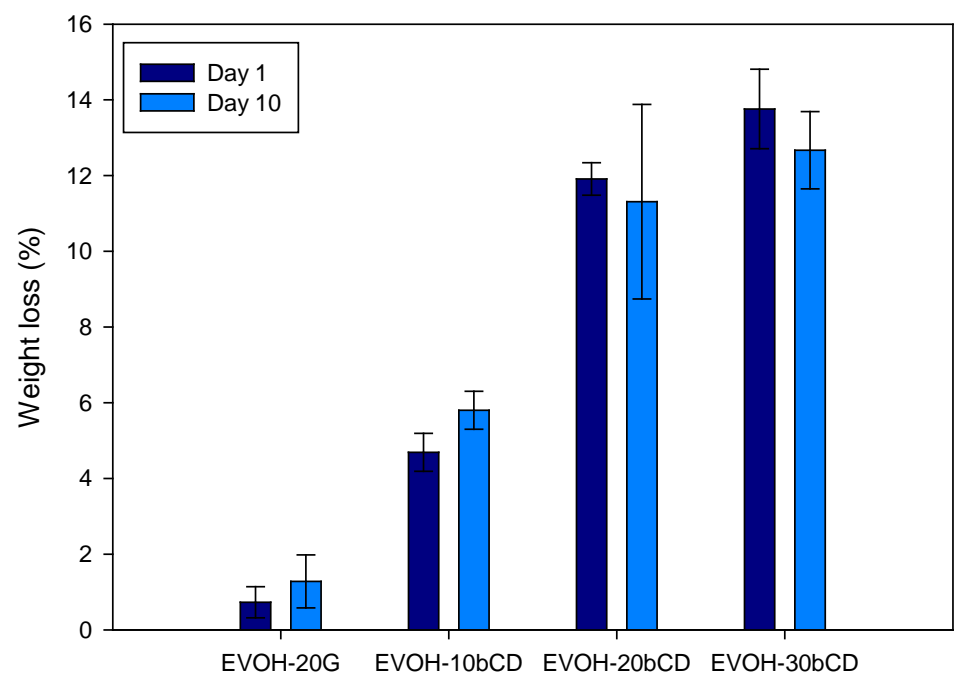

Figure 5.2. Global migration from EVOH materials obtained by extrusion.

Figure 5.2 presents the results of the migration tests. As can be seen, all the $C D$ samples showed high global migration values when exposed to distilled water, the food simulant indicated by EU regulations for non-acid aqueous food products due to the slight water solubility of $\beta C D$.

The samples with glycerol presented global migration values of about $2 \%$. Since pure $\mathrm{EVOH}$ samples presented negligible migration $(<0.1 \%$, not included in the figure), this percentage can be assigned to the loss of plasticizer. However, it is much lower than had been expected from the results reported for hydrophilic biopolymers such as proteins or polysaccharides (Hernandez-Munoz et al., 2004a; Hernandez-Munoz et al., 2004b), where the glycerol used as the plasticizer was fully extracted from the developed films. 
The low values observed in the present work can be interpreted as indicating a high chemical affinity between this polyol and the EVOH copolymer, resulting in a partition equilibrium which favors the polymer over the food simulant. Also, the results show that the migration increases with exposure time, indicating a release process controlled by diffusion.

The EVOH samples with $\beta C D$ and glycerol presented higher migration values than those containing only glycerol. The amount of substances released by the different films increased with the initial $\beta C D$ content. The method used in this assay was gravimetric and therefore does not distinguish between glycerol, $\beta C D$ or other residues and additives. Nevertheless, considering that the release of glycerol should be similar in all the samples, the amount of $\beta C D$ released from the films was below $50 \%$ of the initial content, although the potential synergistic release of the two compounds cannot be disregarded. Also, it was noticeable that the migration values for the samples containing $\beta C D$ were similar on days 1 and 10 . This kind of effect matches up with the case of migration processes limited to the more external zones of the polymeric sample. However, EVOH copolymers are high-barrier materials and although they become plasticized by water, the diffusivity of organic molecules is very slow (Lopez-Carballo et al., 2005). Bearing in mind that $\beta C D$ molecules are very large, cyclic and rigid, their diffusivity in this material should be practically negligible. Considering the SEM images of the samples before and after exposure to the food simulant (Figure 5.1), the larger particles and the aggregated particles might be those most exposed to dissolution in the aqueous medium.

\subsection{Thermal Characterization}

DSC thermogram values for EVOH samples are shown in Figure 5.3 and the more relevant thermal properties are given in Table 5.1. As Figure 5.3 shows, the thermograms of the samples containing $\beta C D$ present several differences with respect to the blank samples. The glass-transition temperature obtained for pure EVOH was $46^{\circ} \mathrm{C}$, in agreement with the $T_{g}$ values reported in the 
literature on this material (Aucejo et al., 1999; Zhang et al., 1999). The addition of $20 \%$ glycerol brought a reduction in the $\mathrm{T}_{\mathrm{g}}$ value of ca. $3{ }^{\circ} \mathrm{C}$. This effect was expected, although the plasticization caused by the addition of this agent was lower than that observed in other hydrophilic biopolymers (Hernandez-Munoz et al., 2004a; Hernandez-Munoz et al., 2004b; Pouplin et al., 1999).

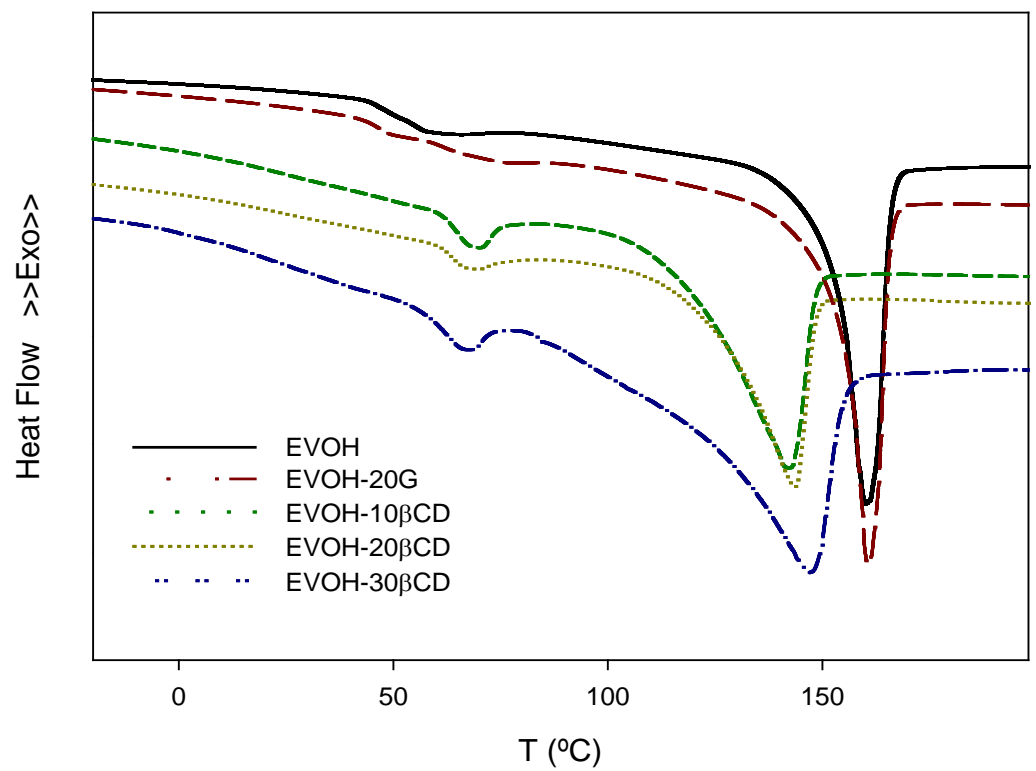

Figure 5.3. DSC thermograms of the different EVOH-based materials during the first heating. 
Table 5.1. Thermal properties of the materials developed: glass transition temperature $\left(T_{g}\right.$, *:onset value), melting enthalpy $(\Delta \mathrm{H})$, melting temperature $\left(T_{m}\right)$ and melting temperature range $\left(\Delta \mathrm{T}_{\mathrm{m}}\right)$.

\begin{tabular}{|c|c|c|c|c|}
\hline Material & $\mathrm{T}_{\mathrm{g}}\left({ }^{\circ} \mathrm{C}\right)$ & $\Delta \mathrm{H}(\mathrm{J} / \mathrm{g})$ & $\mathrm{T}_{\mathrm{m}}\left({ }^{\circ} \mathrm{C}\right)$ & $\Delta \mathrm{T}_{\mathrm{m}}\left({ }^{\circ} \mathrm{C}\right)$ \\
\hline \multicolumn{5}{|l|}{ First heating } \\
\hline EVOH & $46.1 \pm 0.5 b$ & $59.1 \pm 0.9 \mathrm{a}$ & $160.0 \pm 0.3 d$ & $43.3 \pm 1.7 \mathrm{a}$ \\
\hline EVOH-20G & $42.9 \pm 0.4 \mathrm{a}$ & $70.3 \pm 1.0 \mathrm{c}$ & $160.3 \pm 0.2 \mathrm{~d}$ & $38.9 \pm 1.4 \mathrm{a}$ \\
\hline EVOH-10ßCD & $57.7 \pm 0.6^{*} c$ & $72.0 \pm 1.0 \mathrm{c}$ & $141.5 \pm 0.1 \mathrm{a}$ & $64.7 \pm 1.1 b$ \\
\hline EVOH-20ßCD & $57.0 \pm 0.4^{*} c$ & $68.1 \pm 1.0 \mathrm{~b}$ & $143.4 \pm 0.2 b$ & $66.6 \pm 1.4 \mathrm{~b}$ \\
\hline EVOH-30ßCD & $61.6 \pm 0.4^{*} d$ & $71.2 \pm 0.9 c$ & $149.1 \pm 0.2 \mathrm{c}$ & $89.7 \pm 3.5 c$ \\
\hline \multicolumn{5}{|l|}{ Second heating } \\
\hline $\mathrm{EVOH}$ & $43.3 \pm 0.4$ & $67.5 \pm 1.0 \mathrm{~b}$ & $161.7 \pm 0.2 \mathrm{e}$ & $63.6 \pm 2.2 \mathrm{a}$ \\
\hline EVOH-20G & $37.4 \pm 0.5$ & $82.3 \pm 0.8 c$ & $160.8 \pm 0.2 d$ & $61.7 \pm 1.5 \mathrm{a}$ \\
\hline EVOH-10ßCD & & $64.0 \pm 1.3 \mathrm{a}$ & $147.7 \pm 0.3 a$ & $64.4 \pm 1.6 b$ \\
\hline EVOH-20ßCD & & $68.8 \pm 0.6 b$ & $149.8 \pm 0.4 b$ & $73.8 \pm 1.4 b$ \\
\hline EVOH-30ßCD & & $68.8 \pm 0.4 b$ & $151.8 \pm 0.3 c$ & $73.8 \pm 1.4 \mathrm{C}$ \\
\hline
\end{tabular}

Letters (a-e) are mean significant differences among values of a thermal property.

The addition of cyclodextrins to this 'plasticized' copolymer caused an increase in rigidity, with $10-15^{\circ} \mathrm{C}$ increments in $\mathrm{T}_{\mathrm{g}}$ value The values were calculated by the onset of the transition, since the end was hidden by the endothermic feature ascribed to enthalpy relaxation. Figure 5.3 also shows that the crystallinity of EVOH was not affected by the addition of glycerol. The melting temperature value and range were nearly identical. However, the incorporation of the cyclodextrins did influence the melting behavior of the composite materials and, therefore, the copolymer morphology. The presence of cyclodextrins in the polymer matrix reduced the melting temperature. The endothermic minimum fell by $10-15^{\circ} \mathrm{C}$ and the shape of the endothermic 
depression differed, being wider with the addition of the oligosaccharides. These changes can be interpreted as due to the cyclodextrins having a nucleating effect, leading to a reduction in crystal size and a more imperfect crystalline structure (Fairgrieve, 2009). All samples presented a significant increment in the melting enthalpy values. The presence of glycerol appears to be responsible for this effect which could be caused by a greater chain mobility during cooling from the melt. The same effects of a lower melting temperature and a wider transition temperature range were observable during the second heating. However, the $T_{g}$ transitions were not perceptible (no relaxation enthalpy), nor were they detected by the equipment software.

\subsection{Barrier Properties}

\subsubsection{Water vapor transport}

Figure 5.4 shows the results obtained in the sorption experiments. As expected, the water uptake increased with the relative humidity in all the samples. The profile was an S-shape, convex at low humidity values and concave at high $\mathrm{RH}$ values, in agreement with previously reported isotherms for pure EVOH copolymers (Aucejo et al., 2000). The addition of glycerol caused a slight rise in the water gain of $\mathrm{EVOH}$ samples under all the $\mathrm{RH}$ conditions tested. Nevertheless, the differences were not statistically different $(p<0.05)$. With respect to the incorporation of cyclodextrins, the amount of sorbed water increased with the $\beta C D$ content, rising by a factor of 2 for samples with $10 \%$ and by a factor of 3 for samples with $30 \% \mathrm{RH}$. Solubility values were obtained for all the samples and $\mathrm{RH}$ conditions. As can be seen, the water solubility coefficient of the pure EVOH and EVOH-20G samples remained fairly constant at ca. $0.02 \mathrm{Kg} /\left[\mathrm{m}^{3} \cdot \mathrm{Pa}\right]$. These values are in agreement with published values for $\mathrm{EVOH} 44$, although the weak effect of glycerol on water uptake was noticeable, in disagreement with the strong effects observed in hydrophilic biopolymers. The samples containing $\beta C D$ presented values of between 0.04 and $0.06 \mathrm{Kg} /\left[\mathrm{m}^{3} \cdot \mathrm{Pa}\right]$, well above the control samples. This increment could be a consequence of two effects: a) the 
presence in the matrix of empty spots, as shown in the SEM images, which could be filled with water molecules, and b) inclusion of water molecules in the cavity of the $\beta C D$ molecules. According to the literature (Sabadini et al., 2006), the water uptake due to molecule inclusion inside the $\beta C D$ cavity could account for up to $4 \%(w / w)$ for the EVOH-30ßCD samples, close to the amount sorbed by the pure copolymer.

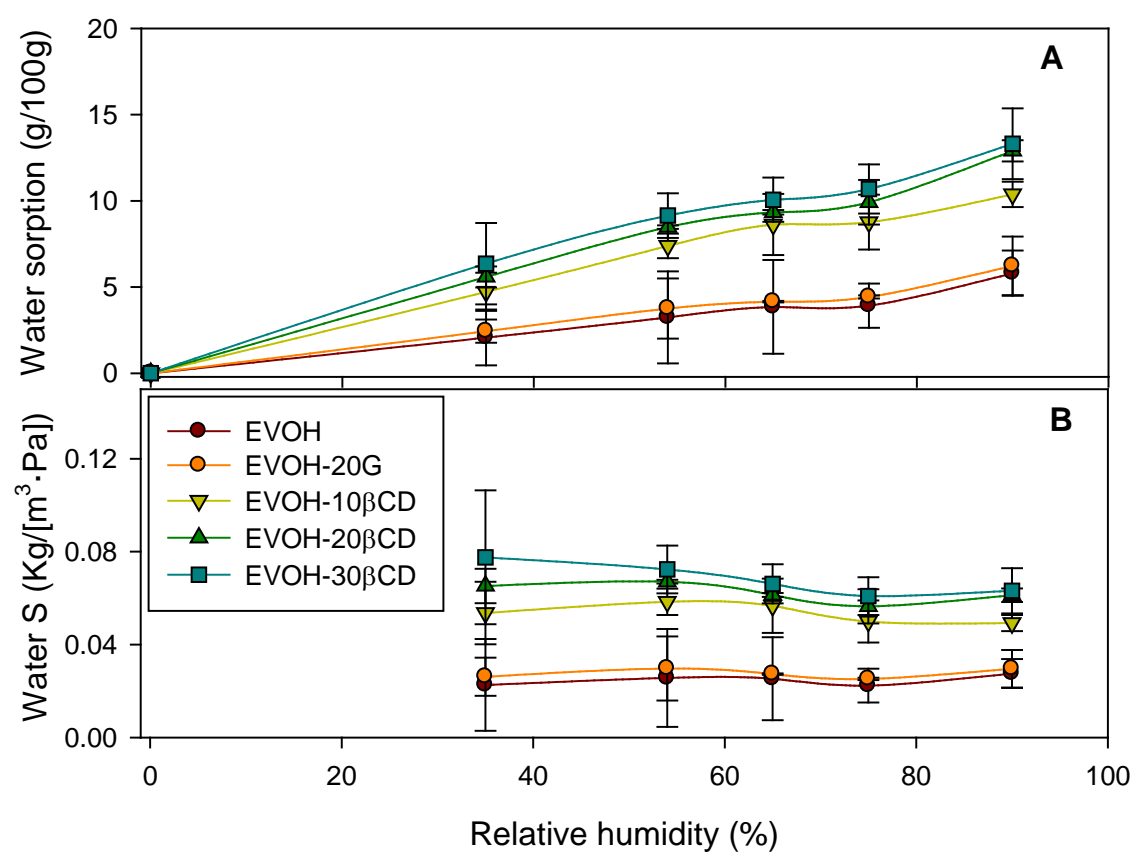

Figure 5.4. Water sorption rates (A) and solubility coefficients (B) of the different $\mathrm{EVOH}$-based materials as a function of relative humidity.

The water permeability through the films was also measured under different relative humidity conditions; the results are plotted in Figure 5.5. As can be seen, all the samples presented the same profile, showing the plasticizing effect of water at high humidities. This effect is in agreement with previous reports in which water permeability was rather constant at low and medium humidity and increased rapidly in very humid environments (Aucejo et al., 2000). The addition of glycerol to EVOH produced a small increase in permeability in all the conditions tested $(p<0.05)$, which can be related to the 
presence of glycerol in the sample and a slight plasticization caused by this polyol as reflected by the reduction in $T_{g}$. The addition of cyclodextrins increased the water permeability of all the samples, especially those with $20 \%$ and $30 \% \beta C D$. This effect could have two causes: a) higher water-solubility in these matrices, as shown in Figure 5.4, and b) an increase in water diffusion resulting from the presence of voids in the matrices and in the polymer/ $\beta C D$ interface. Using the definition of permeability as the product of solubility and the diffusion coefficient $(D)$, the diffusion coefficient can be estimated.

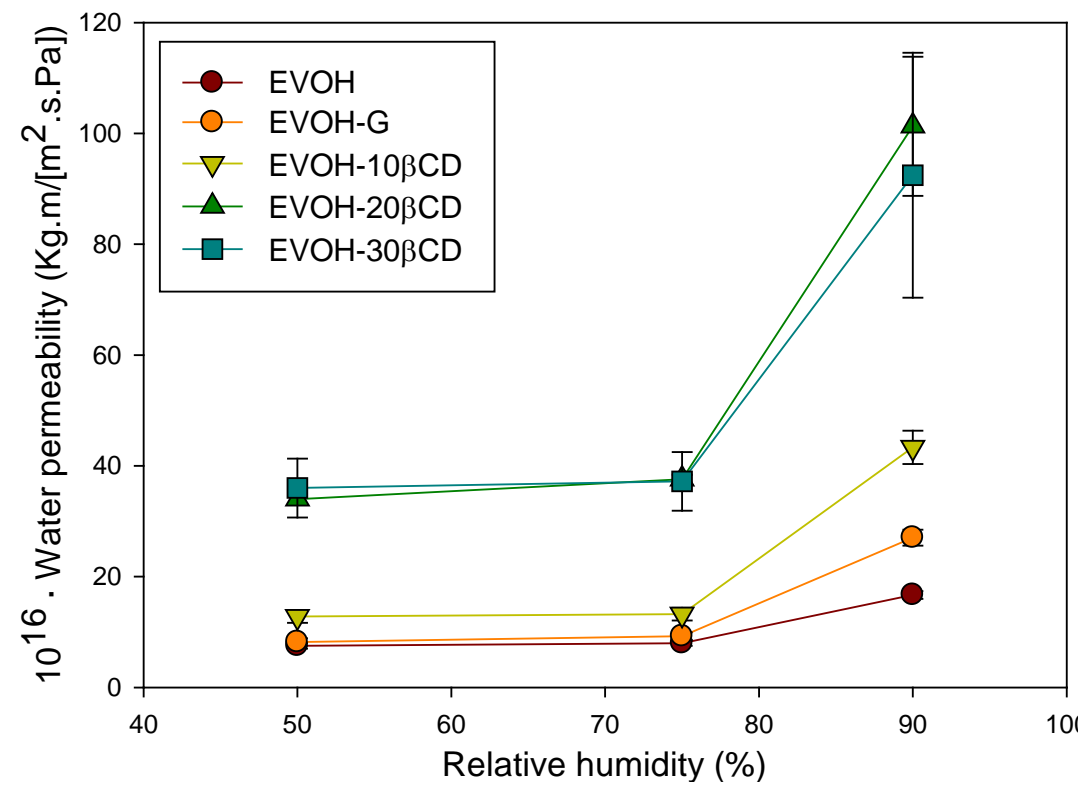

Figure 5.5. Water vapor permeability of film samples at $23^{\circ} \mathrm{C}$ as a function of relative humidity

At $75 \% \mathrm{RH}$, the $D$ values of the control samples were in the $4 \cdot 10^{-14} \mathrm{~m}^{2} / \mathrm{s}$ range, while the $D$ values for the samples with $\beta C D$ rose to $6-7 \cdot 10^{-14} \mathrm{~m}^{2} / \mathrm{s}$. At $90 \%$ $\mathrm{RH}$, the addition of $\beta C D$ raised the $D$ values from 8 to $15 \cdot 10^{-14} \mathrm{~m}^{2} / \mathrm{s}$.

\subsubsection{Gas transport}

Permeability to oxygen and carbon dioxide was also evaluated under two relative humidity conditions: $50 \%$ and $90 \%$. Figure 5.6 shows the values for all 
the samples. As can be seen, the addition of glycerol significantly increased the permeability to oxygen of the EVOH films, especially at low humidity. This effect was greater than for water permeation and is most probably due to the effect of the plasticizer on the diffusivity of this gas. To check this hypothesis, the diffusion coefficient was calculated by applying the analytical solution to Fick's laws for the boundary conditions of an isostatic permeation process (Gavara and Hernández, 1993).

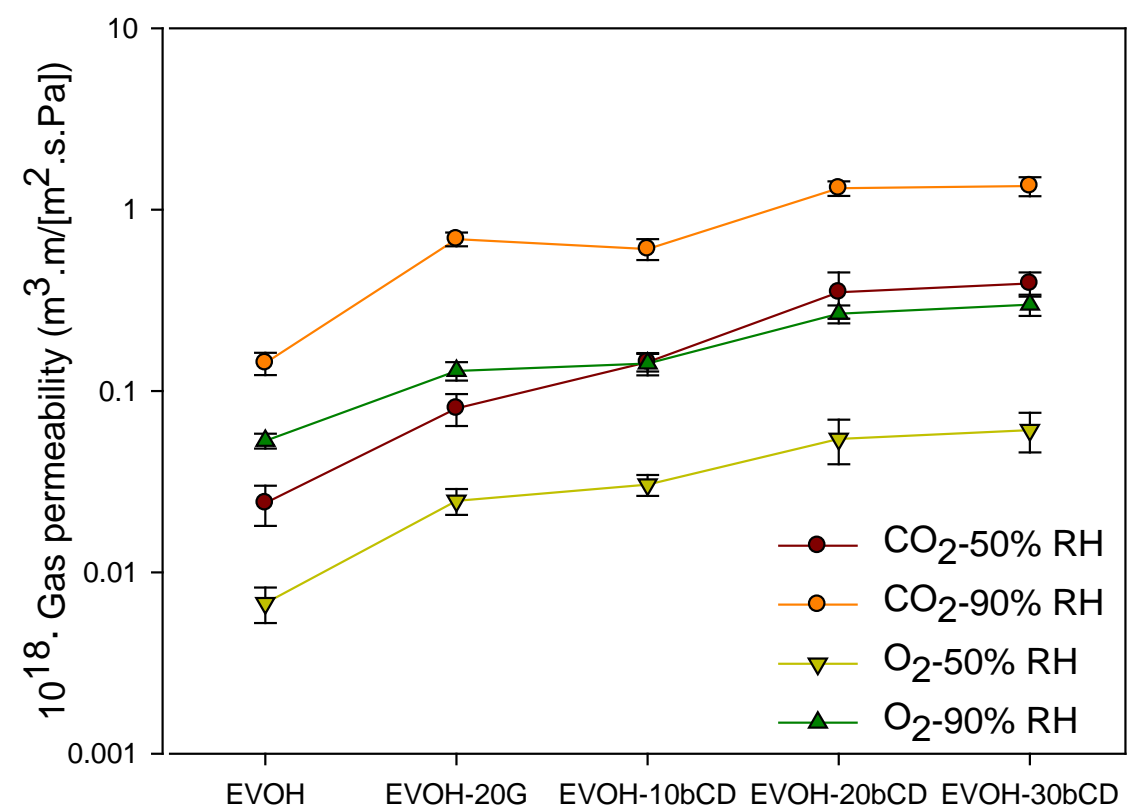

.Figure 5.6. Oxygen and carbon dioxide permeability of film samples at $23^{\circ} \mathrm{C}$, at $50 \%$ and $90 \%$ $\mathrm{RH}$.

The results collected in Figure 5.7 show that the addition of glycerol increased the $D$ value by a factor of 10 at $50 \% \mathrm{RH}$. This increment was similar to that in the EVOH sample caused by the plasticization of water at $90 \% \mathrm{RH}$. The incorporation of cyclodextrins also increased the permeability of the samples to oxygen compared to the pure EVOH sample. However, this increment was not as high as that caused by the plasticizer. The profile obtained at $90 \% \mathrm{RH}$ was very similar to that obtained at $50 \%$. With respect to oxygen diffusivity, the 
addition of $\beta C D$ increased the diffusion coefficient value in proportion to the $\beta C D$ content.

The effect of relative humidity on the oxygen diffusion coefficient of the EVOH sample shows the plasticization caused by water sorption (Aucejo, 2000). This effect was less pronounced in the sample containing glycerol, since the material was partially plasticized by this agent. The effect is even smaller in the presence of $\beta C D$. Discontinuities in the matrix and transport through $\beta C D$ cavities may be responsible for the greater diffusivity of the $\beta C D$ films, where water uptake is a less important factor than in the polymeric matrix.

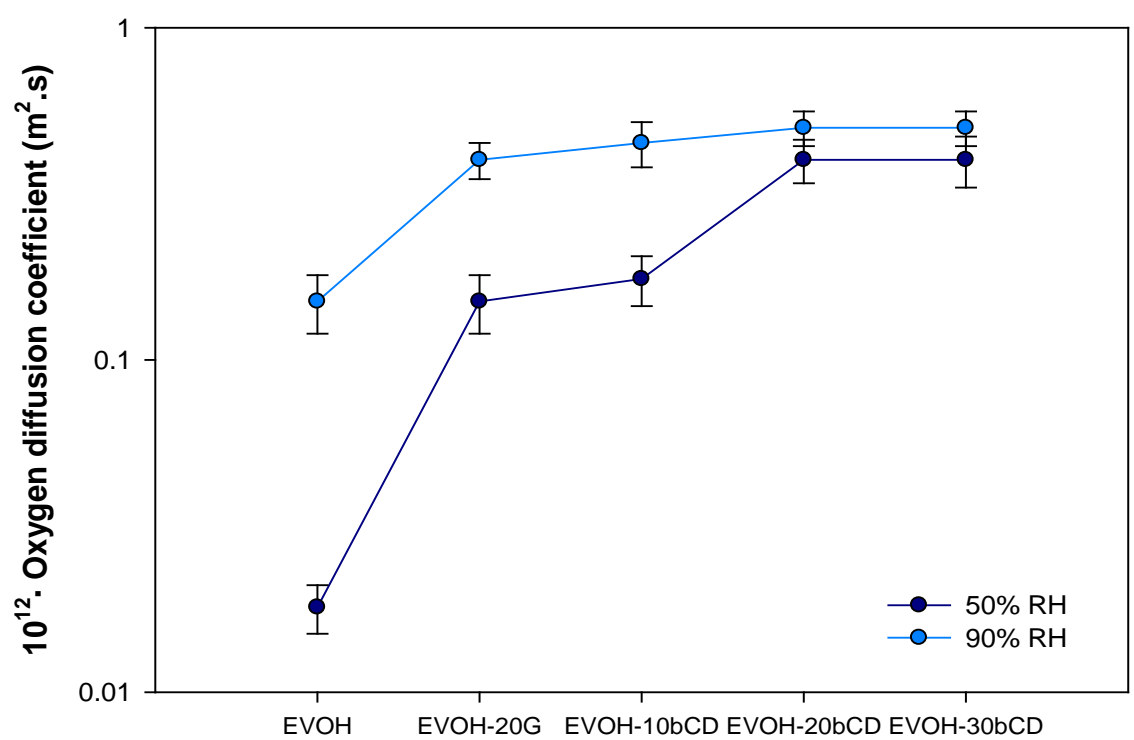

Figure 5.7. Oxygen diffusion coefficient values for the different film samples at $23^{\circ} \mathrm{C}$, at $50 \%$ and $90 \% \mathrm{RH}$.

Finally, the permeability of these materials to carbon dioxide was also measured, due to the growing importance of this property in current packaging technologies (MAP, high barrier packaging, active packaging, etc.). The results shown in Figure 5.6 present the same profile as the oxygen permeability values. However, the permselectivity of the EVOH was altered by the presence of $\beta C D$ : the carbon dioxide permeability was 3-4 times higher than the oxygen permeability in the $\mathrm{EVOH}$ control samples, but 5-6 times higher in 
the samples containing $\beta C D$. This might be caused by an increase in the solubility of carbon dioxide in the composite matrices. Unfortunately, the experimental method did not allow evaluation of $D$, which would have helped to confirm this hypothesis.

\subsection{Retention of organic compounds}

It is well known that polymer-based packages have interactions with organic compounds present in food. This characteristic, known as aroma scalping, may affect the sensory characteristics of the packaged food product, causing a reduction in aroma intensity or an unbalanced aroma due to the preferential retention of certain compounds. Therefore, in order to optimize the packaging design, it is important to study the potential food aroma interaction that a new material may present.

In this work, a preliminary experiment was carried out to study the relationship between the polarity of the organic compounds and the complexation capacity of $\beta C D$. For this purpose, $\beta C D$ was added to a hydroalcoholic solution of several organic compounds at a concentration of $5 \mathrm{ppm}(\mathrm{w} / \mathrm{v})$. The amount of oligosaccharide added was calculated to achieve a molar ratio of 500/1 $\beta C D /$ organic compounds. After two days of contact, the samples were filtered and the concentration of non-encapsulated organic compounds $\left(A_{\text {free }}\right)$ was calculated by gas chromatography. The results were expressed as the value of the equilibrium constant:

$$
K=\frac{\left[A_{\text {complexed }}\right]}{\left[A_{\text {free }}\right]}
$$

The concentrations of complexed organic compounds $\left(A_{\text {complexed }}\right)$ were estimated by subtraction from the nominal concentrations. Figure 5.8 presents the complexation constant value as a function of the Hildebrand coefficient $(\delta)$, which is related to the polarity of substances (Brandrup and Immergut, 1989). As can be seen, the highest complexation values were obtained for the most apolar compounds, those with the lowest Hildebrand coefficient values. 
Aproximately $90 \%$ of the $\alpha$-pinene and limonene molecules were complexed by $\beta C D$. At the other extreme, the most polar compound tested, hexanol, presented the lowest $K$ value. Only $20 \%$ of the hexanol molecules formed inclusion complexes with the oligosacharides. These results are in agreement with previous published results in which terpenes and sesquiterpenes from various plant extracts were highly encapsulated and protected by $\beta C D$ (Goubet et al., 1998; Szente and Szejtli, 2004).

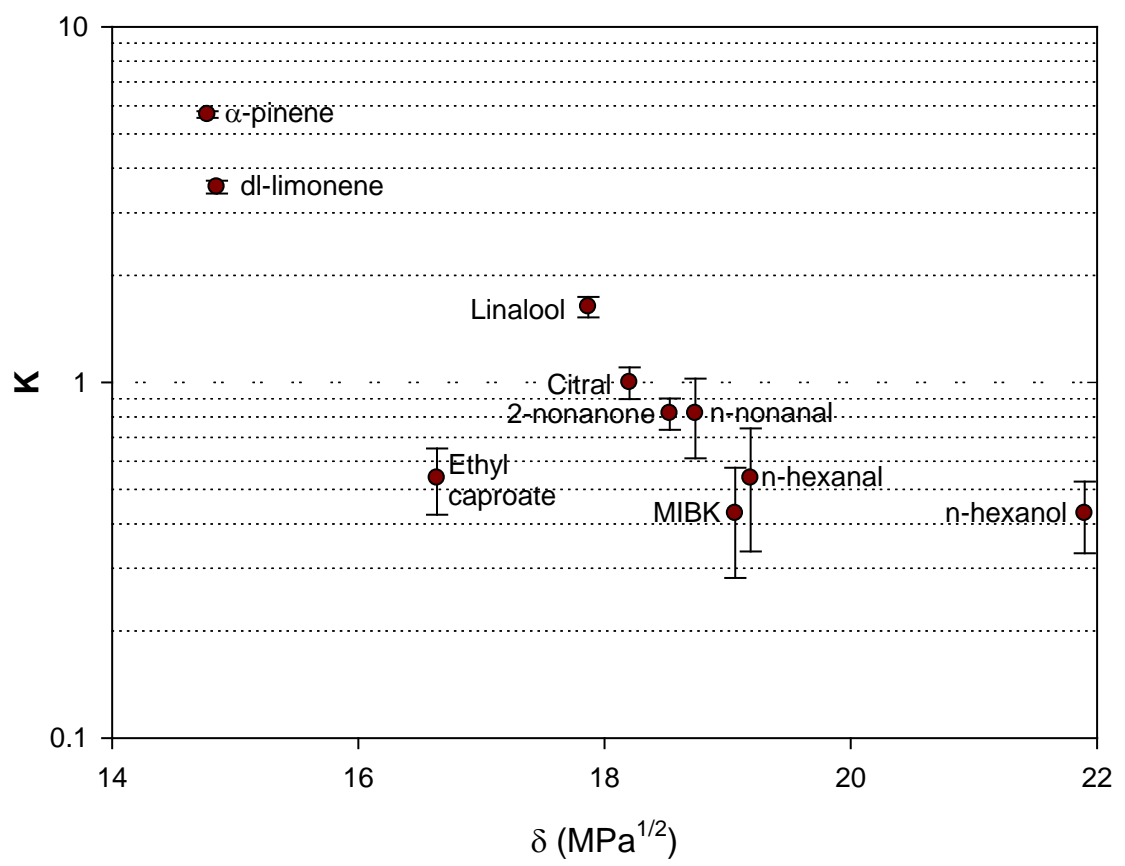

Figure 5.8. Effect of thepolarity of aroma compounds on the complexation capacity of $\beta C D$.

Another set of experiments was prepared with the materials under development. Control EVOH films and those containing $\beta C D$ were immersed in water for 24 hours at $40{ }^{\circ} \mathrm{C}$ and then dried under vacuum for 48 hours to eliminate the cyclodextrin molecules which are released from the films. In this way, the potential organic compound complexation caused by released $\beta C D$ 
can be considered negligible. Then, films were immersed in hydroalcoholic solutions of pinene, limonene and $n$-hexanal. The two terpenes were selected because of their great affinity for the $\beta C D$. The hexanal was selected since it is an organic compound which is formed as a consequence of oxidative degradation of fats, and scavenging it could be a potential application of the materials for active food packaging. The amounts of film and of the hydroalcoholic solution were selected to obtain a $\beta C D / o r g a n i c$ compounds molar ratio of 1:1, 2:1 and 3:1 for the EVOH-10ßCD, EVOH-20ßCD and $E V O H-30 \beta C D$ respectively. For the control tests, a similar sample was prepared with $\mathrm{EVOH}-20 \mathrm{G}$ as the control and another by adding $\beta C D$ in a $\beta C D /$ organic compounds molar ratio of $1: 1$. As Figure 5.9 shows, in all the samples the highest retention was obtained with the most apolar compounds.

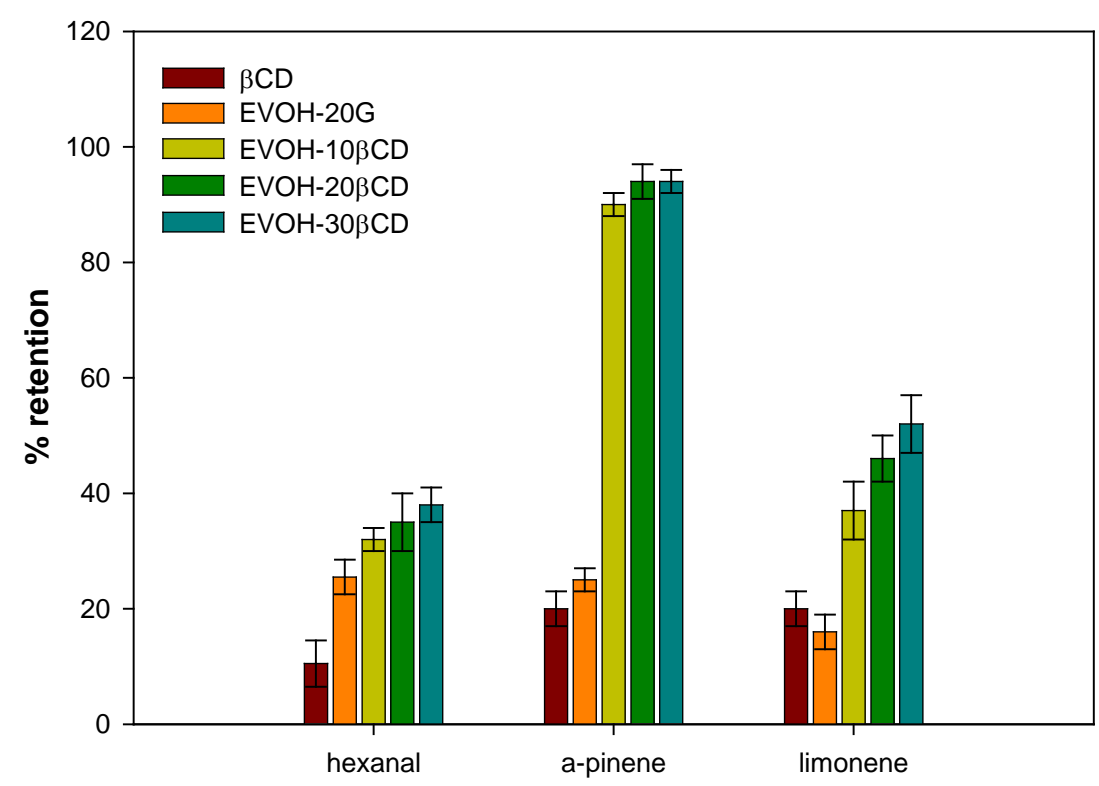

Figure 5.9. Retention of volatile components by the different samples.

It is interesting to observe the sorption of components by the polymeric matrix. The quantity retained by the polymer is similar or even higher in comparison to free cyclodextrins. EVOH is known to be a high barrier material for organic compounds when dry, but it has been reported that water plasticization severely damages the barrier properties of this family of copolymers. Thus, 
EVOH with glycerol is highly plasticized when immersed in the hydroalcoholic solution, and organic compounds can easily diffuse though the matrix.

The materials developed in this study presented much higher retention values because of complexation with immobilized cyclodextrins, mainly of terpenic compounds. This high retention also provides confirmation of the availability of the $\beta C D$ cavity for sorption of compounds. Therefore, it may be concluded that $E V O H$ materials containing immobilized $\beta C D$, prepared by regular extrusion, can be used to design active food packaging that uses the $\beta C D$ cavity for the inclusion or retention of apolar organic compounds. At present, these materials are being tested with real products to observe their capacity to retain undesirable compounds such as hexanal or cholesterol.

\section{CONCLUSIONS}

$\beta$-Cyclodextrin was successfully incorporated in an ethylene-vinyl alcohol copolymer with a $44 \%$ molar percentage of ethylene by regular extrusion with the aid of glycerol to improve the dispersion of the oligosaccharide. Although the composite presented phase separation, the films were continuous and transparent and their thermal properties did not present great changes. The barrier properties to gases and water decreased slightly due to the increase of free volume in the matrix. Also, the $\mathrm{CO}_{2} / \mathrm{O}_{2}$ permselectivity increased, attribute with interesting uses in MAP. It is noticeable that the presence of $\beta C D$ increased their apolar organic compound sorption capacity, a characteristic which could be useful in active packaging design and in the preparation of composite membranes for preferential sorption of organic compounds.

\section{ACKNOWLEDGEMENTS}

The authors acknowledge the financial support of the Spanish Ministry of Science and Innovation, projects AGL2006-02176, AGL2009-08776 and FunC-Food CSD2007-00063, and the C. L-d-D fellowship (FPU program). Mary Georgina Hardinge provided assistance with the English language text. 


\section{REFERENCES}

Akiyama, Y., Miyao, K., (1979). Microencapsulation of royal jelly. Jpn. Kokai. JP80, 463.

Aucejo, S., (2000). Study and characterization of the humidity effect on the barrier properties of hydrophillic polymeric structures. Ph.D. Dissertation_Univ.Valencia (Spain).

Aucejo, S., Catala, R., Gavara, R., (2000). Interactions between water and EVOH food packaging films. Food Science and Technology International 6(2), 159-164.

Aucejo, S., Marco, C., Gavara, R., (1999). Water effect on the morphology of EVOH copolymers. Journal of Applied Polymer Science 74(5), 1201-1206.

Brandrup, J.Y., Immergut, E.H., (1989). Polymer Handbook, in: Sons, J.W. (Ed.), 3rd ed., New York.

Comini, S., Mentink, L., (1994). Process for refining mixtures resulting from treatment of fatty substances with cyclodextrin and containing complexes of cyclodextrin with fatty acid type lipophilic compounds. Roquette Freres, France, United States.

European Economic Community, (1989). Council Directive of 21 December 1988. Official Journal European Community 32(L40), 38-44.

European Economic Community, (1990). Council Directive 90/128/EEC of 23 February 1990, Official Journal European Community, 26-47.

Fairgrieve, S., (2009). Nucleating Agents: Rapra Review Reports. Woodhead Publishing Limited, Cambridge.

Garde, J.A., Catala, R., Gavara, R., (1998). Global and specific migration of antioxidants from polypropylene films into food simulants. Journal of Food Protection 61(8), 1000-1006.

Gavara, R., Catala, R., Hernández-Muñoz, P., Hernández, R.J., (1996). Evaluation of permeability through permeation experiments. Isostatic and quasi-isostatic methods compared. Packag. Technol. Sci. 9, 215-234.

Gavara, R., Hernández, R.J., (1993). Consistency test for continuos flow permeability experimental data, in: Sheeting, J.o.P.F. (Ed.), 126-138.

Goubet, I., Le Quere, J.L., Voilley, A.J., (1998). Retention of aroma compounds by carbohydrates: Influence of their physicochemical characteristics and of their physical state. A review. Journal of Agricultural and Food Chemistry 46(5), 19811990. 
Grob, K., Biedermann, M., Scherbaum, E., Roth, M., Rieger, K., (2006). Food contamination with organic materials in perspective: Packaging materials as the largest and least controlled source? A view focusing on the European situation. Critical Reviews in Food Science and Nutrition 46(7), 529-535.

Grob, K., Pfenninger, S., Pohl, W., Laso, M., Imhof, D., Rieger, K., (2007). European legal limits for migration from food packaging materials: 1 . Food should prevail over simulants; 2. More realistic conversion from concentrations to limits per surface area. PVC cling films in contact with cheese as an example. Food Control 18(3), 201-210.

Hernandez-Munoz, P., Lopez-Rubio, A., Del-Valle, V., Almenar, E., Gavara, R., (2004a). Mechanical and water barrier properties of glutenin films influenced by storage time. Journal of Agricultural and Food Chemistry 52(1), 79-83.

Hernandez-Munoz, P., Villalobos, R., Chiralt, A., (2004b). Effect of cross-linking using aldehydes on properties of glutenin-rich films. Food Hydrocolloids 18(3), 403-411.

Hopfenberg, H.B., Apicella, A., Saleeby, D.E., (1981). Factors affecting water sorption in and solute release from glassy ethylene-vinyl alcohol copolymers. Journal of Membrane Science 8(3), 273-282.

ISO 2528:1995, (1995). Sheet Materials - Determination of water vapor transmission rate (gravimetric (dish) method).

Kusumocahyo, S.P., Kanamori, T., Sumaru, K., Iwatsubo, T., Shinbo, T., (2004). Pervaporation of xylene isomer mixture through cyclodextrins containing polyacrylic acid membranes. Journal of Membrane Science 231(1-2), 127-132.

Lopez-Carballo, G., Cava, D., Lagaron, J.M., Catala, R., Gavara, R., (2005). Characterization of the interaction between two food aroma components, alphapinene and ethyl butyrate, and ethylene-vinyl alcohol copolymer (EVOH) packaging films as a function of environmental humidity. Journal of Agricultural and Food Chemistry 53(18), 7212-7216.

Lue, S.J., Peng, S.H., (2003). Polyurethane (PU) membrane preparation with and without hydroxypropyl-beta-cyclodextrin and their pervaporation characteristics. Journal of Membrane Science 222(1-2), 203-217.

Pouplin, M., Redl, A., Gontard, N., (1999). Glass transition of wheat gluten plasticized with water, glycerol, or sorbitol. Journal of Agricultural and Food Chemistry 47(2), 538-543.

Reineccius, T.A., Reineccius, G.A., Peppard, T.L., (2002). Encapsulation of flavors using cyclodextrins: Comparison of flavor retention in alpha, beta, and gamma types. Journal of Food Science 67(9), 3271-3279. 
Sabadini, E., Cosgrove, T., Egidio, F.C., (2006). Solubility of cyclomaltooligosaccharides (cyclodextrins) in $\mathrm{H}_{2} \mathrm{O}$ and $\mathrm{D}_{2} \mathrm{O}$ : a comparative study. Carbohydrate Research 341(2), 270-274.

Sanchez-Chaves, M., Fernandez-Garcia, M., Cerrada, M.L., (2007). Ethylene-vinyl alcohol copolymers partially modified with benzoate groups: Study of their polymorphic behavior. Journal of Polymer Science Part B-Polymer Physics 45(9), 1026-1036.

Shaw, P.E., Wilson, C.W., (1983). Debittering citrus juices with beta-cyclodextrin polymer. Journal of Food Science 48(2), 646-647.

Specht, M., Rothe, M., Szente, L., Szejtli, J., (1981). Removal of phenylalanine from protein hydrolysates. J. Ger. Offen. 147, 615.

Szente, L., Szejtli, J., (2004). Cyclodextrins as food ingredients. Trends in Food Science \& Technology 15(3-4), 137-142.

Touil, S., Palmeri, J., Tingry, S., Bouchtalla, S., Deratani, A., (2008). Generalized dualmode modelling of xylene isomer sorption in polyvinylalcohol membranes containing alpha-cyclodextrin. Journal of Membrane Science 317(1-2), 2-13.

Vermeiren, L., Devlieghere, F., van Beest, M., de Kruijf, N., Debevere, J., (1999). Developments in the active packaging of foods. Trends in Food Science \& Technology 10(3), 77-86.

Wood, W.E., Beaverson, N.J., (1996). Thermoplastic barrier film compsn. used for food packing|comprises vinyl! polymer thermoplastic web contg. dispersed cyclodextrin deriv., free of inclusion complex cpd. Aspen Res Corp; Cellresin Technologies Llc.

Xiao, Y.C., Chung, T.S., (2007). Functionalization of cellulose dialysis membranes for chiral separation using beta-cyclodextrin immobilization. Journal of Membrane Science 290(1-2), 78-85.

Yamasaki, A., Iwatsubo, T., Masuoka, T., Mizoguchi, K., (1994). Pervaporation of ethanol-water through a poly(vinyl alcohol) cyclodextrin (PVACD) membrane. Journal of Membrane Science 89(1-2), 111-117.

Yu, E.K.C., (1988). Novel decaffeination process using cyclodextrins. Applied Microbiology and Biotechnology 28(6), 546-552.

Zhang, Z.B., Britt, I.J., Tung, M.A., (1999). Water absorption in EVOH films and its influence on glass transition temperature. Journal of Polymer Science Part B Polymer Physics 37 (7), 691-699. 
Artículo 6

FOOD APPLICATIONS OF ACTIVE PACKAGING EVOH

FILMS CONTAINING CYCLODEXTRINS FOR THE PREFERENTIAL SCAVENGING OF UNDESIRABLE COMPOUNDS

Carol López-de-Dicastillo, Ramón Catalá, Rafael Gavara, Pilar Hernández-Muñoz

Journal of Food Engineering 2011, 58, 10958-10964 


\section{ABSTRACT}

Novel ethylene-vinyl alcohol copolymer (EVOH) films containing betacyclodextrins $(B C D)$ with potential application in active food packaging have been tested as materials for the preferential retention of undesired food components. The films were immersed on pasteurized milk and UHT milk and stored at 4 and $23^{\circ} \mathrm{C}$, respectively. The films containifod presented a significant reduction in cholesterol concentration, achieving a $23 \%$ reduction in UHT milk exposed to EVOH films containing 30\% $\beta C D$. Despite the immobilization of the $\beta C D$ and the large molecular size of cholesterol, $15 \%$ of the $\beta C D$ molecules added to the films were involved in the formation of $\beta C D /$ cholesterol inclusion complexes. In another set of experiments, the films were used to reduce the presence of aldehydes (substances which develop as a result of oxidative processes) in packaged fried peanuts. The films containing $\beta C D$ brought a significant reduction in hexanal, reaching a $50 \%$ decrease over short periods (1-5 weeks). At longer storage times (10 weeks) the retention capacity of the developed films was exhausted and no differences were observed between the samples.

Keywords: active packaging; cyclodextrins; $\mathrm{EVOH}$; cholesterol scavenging; aldehydes retention; lipid oxidation 


\section{INTRODUCTION}

Active packaging is one of the emerging technologies which is being developed as an alternative to traditional food processing (intense heat treatments, salting, acidification, drying and chemical preservation). Active packaging does more than simply provide a barrier to external detrimental factors, as the packaging system plays an active role in food preservation and quality during the marketing process (López-Rubio et al., 2004). Active packaging materials are designed to deliberately incorporate components that release or absorb substances into or from the packaged food or the environment surrounding the food to extend the shelf-life or to maintain or improve the condition of the packaged food (Regulation (CE) No 450/2009 (29/05/2009)). Nowadays, active material developments are focusing on polymeric matrices which release active agents (antimicrobials, antioxidants, etc.) and/or retain substances such as oxygen, ethylene or water (Charles et al., 2006; Flores et al., 2007) or undesired food components. While the scavengers used in the latter applications are mainly based on inorganic metals or salts, which have mechanisms of action based on irreversible reactions, the present work studies the use of cyclodextrins as potential scavengers.

Beta-cyclodextrin $(\beta C D)$ is an inexpensive enzyme-modified starch derivative, composed of seven glucose units linked by a $\$ 14)$ glycos idic bonds in a cylindrically shaped cavity with a hydrophobic inner surface and a hydrophilic outer surface. The hydrophobic cavity is able to form inclusion complexes with a wide range of organic guest molecules principally by means of weak forces, such as van der Waals, dipole-dipole interactions, and hydrogen bonding. The use of cyclodextrins has increased annually in the food sector (Astray et al., 2009) mainly to remove cholesterol but also as carriers for molecular encapsulation of flavors and other sensitive ingredients. Several reviews have been published describing their possible applications in food processing and as food additives with different aims (Cravotto et al., 2006), although their use is mainly based on the direct addition of the oligosaccharides to the liquid food, 
and precipitation and separation of the resulting inclusion complexes. In this work, the retention capacity of $\beta C D$ immobilized in packaging structures is explored.

Cholesterol (cholest-5-ene-3- $\beta-0 l$ ) is an apolar molecule and its size is compatible with filling the $\beta$-cyclodextrin cavity. In the literature it is possible to find cholesterol/ $\beta C D$ complexation ratios ranging from 1:1 to 1:3 (Yamamoto et al., 2005). The main driving force for complex formation is the release of enthalpy-rich water molecules from the cavity. Water molecules are displaced by more hydrophobic guest molecules present in the solution to attain an apolar-apolar association and a decrease of cyclodextrin ring strain resulting in a more stable lower energy state. Cholesterol has already been removed from milk and dairy products by a $\beta C D$-based process, and the resulting lowcholesterol butter and cheese are indistinguishable from untreated products (Schroder \& Baer, 1990).

Complexation with a wide range of organic molecules has already been researched and demonstrated. Cyclodextrins (CDs) have been used to retain and/or release volatile compounds, such as aromes, aldehydes, ketones, etc (Almenar et al., 2007, Szejtli, 1982). Previous analysis showed that complexation is related to the polarity of substances, the most apolar compounds having the highest complexation values (López de Dicastillo et al., 2010). Lipid oxidation of stored peanuts leads indirectly to the formation of aliphatic aldehydes, ketones and alcohols, (Burroni et al., 1997; Wambura and Yang, 2010; Williams et al., 2006). Lipids are the major components in peanuts, where approximately $80 \%$ are unsaturated. Oxidation products and rancid flavors decrease the sensory quality of peanut products at very low concentrations, making them unacceptable to consumers, even before the end of their shelf life.

In a previous work (López de Dicastillo et al., 2010), different concentrations of $\beta C D$ were incorporated by extrusion into a hydrophilic ethylene-vinyl alcohol copolymer (EVOH). The films obtained, when exposed to a mixture of organic compounds, presented preferential sorption capacity for apolar compounds. 
The aim of this work was to use these materials with real food products to reduce the levels of undesired components. Concretely, the films were used to scavenge undesired compounds through the formation of inclusion complexes: a) reducing the cholesterol content of milk by direct contact of the food product with the packaging films, and b) reducing the oxidation byproducts in the package headspace of fried peanuts.

\section{MATERIALS AND METHODS}

\subsection{Chemicals and Reagents}

The ethylene vinyl alcohol copolymer with a 44\% ethylene molar content (EVOH) was kindly supplied by The Nippon Synthetic Chemical Company, (Osaka, Japan). $\beta C D$ was obtained from Wacker (Barcelona , Spain), glycerol from Sigma (Madrid, Spain) and, cholesterol, 5a-cholestane and potassium hydroxide from Fluka Biochemika (Barcelona, Spain). Hexane and methanol were from Merck (Barcelona, Spain) and pentanal, hexanal, heptanal, 2-heptenal, octanal, and 2-octenal from Sigma (Madrid, Spain). Molecular weights and sizes of $\beta C D$ cyclodextrins, cholesterol and selected aldehydes have been included in Table 6.1.

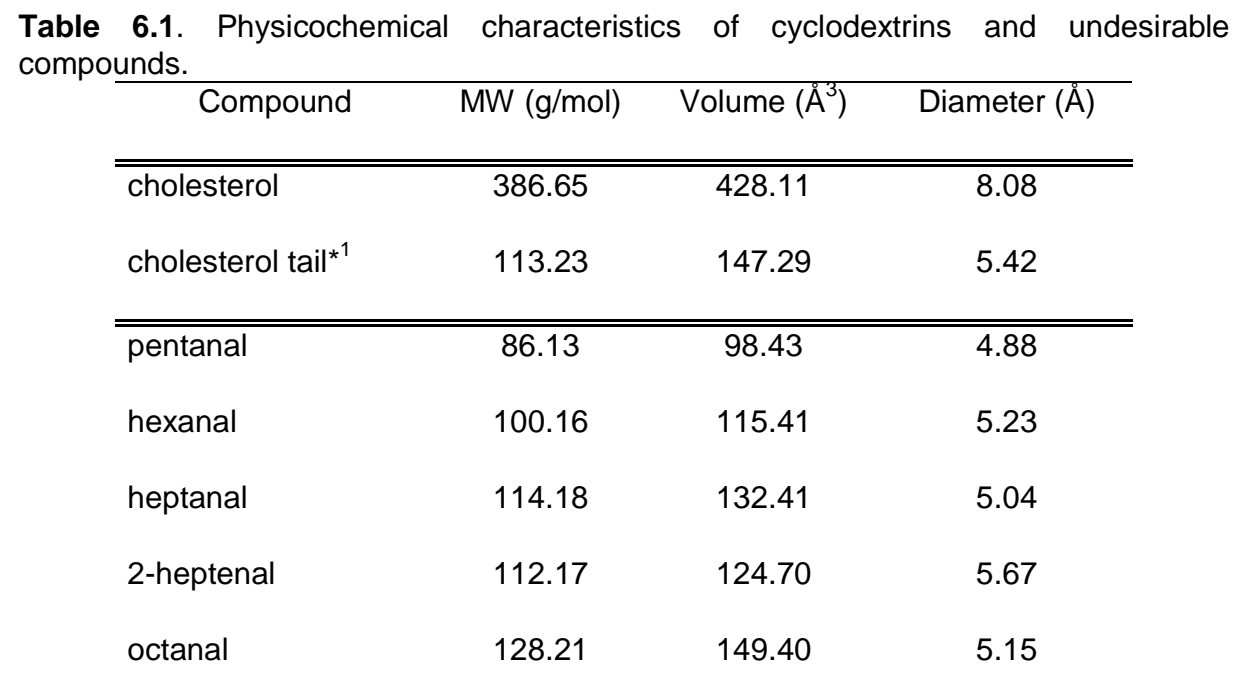




\begin{tabular}{lccc} 
2-octenal & 126.10 & 141.67 & 5.58 \\
\hline$\beta$-cyclodextrin ${ }^{2}$ & 1135.00 & 262.00 & $6.00-6.50$ \\
\hline${ }^{1}$ Corresponds to the alquilic chain of cholesterol molecule (6-methylheptyl). \\
$\star^{2}$ Corresponds to the inner cavity of the cyclodextrin.
\end{tabular}

Water was treated by a Milli-Q Plus purification system (Millipore, Molsheim, France). Hacendado ${ }^{\mathrm{TM}}$ fried peanuts and pasteurized whole milk and UHT whole milk were acquired from a local supermarket (Mercadona, Valencia, Spain).

\subsection{Film Preparation}

$\beta$-cyclodextrins were incorporated at two different concentrations (20 and 30\% w/w) into the hydrophilic EVOH material by flat extrusion. Polymer pellets were previously dried during two days at $60{ }^{\circ} \mathrm{C}$ under vacuum. In a previous trial, the direct addition of $\beta C D$ into the extruder hopper produced very deficient films with holes and $\beta C D$ agglomerates and a poor distribution of the oligosaccharides. For this reason, a glycerol- $\beta C D$ 1:1 (w:w) paste was prepared, mixed with the polymer pellets, and melt blended during extrusion in a Brabender DSE 20/40 co-rotating twin screw extruder (Plastograph, Dusseldorf, Germany) with a screw speed of $100 \mathrm{rpm}$ and with the following thermal profile: $160^{\circ} \mathrm{C}, 180^{\circ} \mathrm{C}, 200^{\circ} \mathrm{C}, 190^{\circ} \mathrm{C}$ in the barrel and $190^{\circ} \mathrm{C}$ at the flat die.

The addition of glycerol improved the miscibility of the $\beta C D$ and the polymer during the extrusion process and a more homogeneous distribution of the oligosaccharide was achieved The resulting films were ca. $50 \mu \mathrm{m}$ thick, although the thickness of every sample was individually measured with a digital Mitutoyo micrometer (Metrotec, San Sebastian, Spain) at 10 positions in the measured area before conducting the experiments. To avoid contaminations, film samples were vacuum-packed in aluminum/LDPE bags and stored at room temperature until the moment of analysis. 
The transparency of the films was determined through the surface reflectance spectra in a spectrocolorimeter CM-3500d (Minolta Co, Tokyo, Japan) with a $30 \mathrm{~mm}$ illuminated sample area. Measurements were taken from three samples in each formulation by using both a white and a black background. The transparency was determined by applying the Kubelka-Munk theory for multiple scattering to the reflection spectra. As each light flux passes through the layer, it is affected by the absorption coefficient $(K)$ and the scattering coefficient (S). Transparency (KIS) was calculated, as indicated by Hutchings (1999), from the reflectance of the sample layer on a known reflectance background and on an ideal black background. Also, the internal transmittance was evaluated. Further details on the procedure can be found in Fabra et al. (2010).

\subsection{Cholesterol in milk}

\subsubsection{Milk sample preparation}

In the present work, prior to any test, the film samples were immersed in water under agitation for 24 hours, to eliminate any polymer residues (including cyclodextrins) which could migrate out of the film, and then dried with a tissue paper and subsequently in a vacuum oven at $40^{\circ} \mathrm{C}$ for 24 hours. This way, no retention or scavenging could be attributed to inclusion complexes formed outside of the active film. To simulate the conditions of a conventional package for pasteurized whole milk, a piece of film was placed in contact with real milk at a surface/volume ratio equivalent to that of a $1 \mathrm{~L}$ carton. After sterilizing the film surfaces by UV irradiation for $15 \mathrm{~min}$, approximately $12.8 \mathrm{~cm}^{2}$ of each of the films were immersed in $20 \mathrm{~mL}$ of pasteurized whole milk and kept at $4{ }^{\circ} \mathrm{C}$ for one week in a closed vial covered by aluminum foil to avoid any potential effect of light.

In a second experiment, the UV irradiated film samples were immersed in 20 $\mathrm{mL}$ of UHT whole milk and kept at $23^{\circ} \mathrm{C}$ for one week. In this experiment, the milk package, films, vials and milk were handled under sterile conditions to 
prevent the risk of bacterial contamination and milk spoilage.The experiments were carried out in quintuplicate.

\subsubsection{Cholesterol determination}

The determination of cholesterol in milk was carried out by a simple and rapid method based on direct saponification of the samples with methanolic $\mathrm{KOH}$ solution (Fletouris et al., 1998). A $0.3 \mathrm{~g}$ sample of milk was accurately weighed into a sample preparation vial and $5 \mathrm{~mL}$ of $0.5 \mathrm{M} \mathrm{KOH}$ methanolic solution were added, followed by $40 \mu \mathrm{L}$ of a hexanolic solution of $5 \alpha$-cholestane 1 $\mathrm{mg} / \mathrm{mL}$ as the internal standard. The vial was closed tightly and vortexed for 15 s. The vial was then immersed in a $75^{\circ} \mathrm{C}$ bath under agitation for $25 \mathrm{~min}$. Several vials with different samples could be handled conveniently by placing them in a wire basket. Following heating, the vials were cooled to room temperature, $1 \mathrm{~mL}$ of water and $5 \mathrm{~mL}$ of hexane were added, and the contents were vortexed vigorously for $1 \mathrm{~min}$ and then centrifuged for $3 \mathrm{~min}$ at $1500 \mathrm{rpm}$. An aliquot of the upper phase was injected for GC analysis.

The cholesterol concentration was determined in a fused capillary column (30 $\mathrm{m} \times 0.22 \mathrm{~mm} \times 0.22 \mu \mathrm{m}$ ) model TRB-STEROL (Teknokroma S. Coop. C. Ltda., Barcelona, Spain) using an HP 5890 gas chromatograph (Agilent Technologies, Barcelona, Spain) equipped with a flame ionization detector. The chromatographic conditions were as follows: He carrier gas, $4 \mu \mathrm{L}$ sample injection volume, $1 / 20$ split ratio, isothermal running at $285^{\circ} \mathrm{C}$ for 15 minutes, injection port temperature $300{ }^{\circ} \mathrm{C}$, and flame ionization detector temperature $300^{\circ} \mathrm{C}$. The cholesterol was quantified through a 5 point calibration curve with $5 \alpha$-cholestane as the internal standard. A linear peak area/concentration response $(r=0.998)$ was observed within the tested range $(1-300 \mathrm{mg} / \mathrm{L})$. The analysis was carried out in triplicate and the cholesterol in the control/blank samples was determined for each batch of test samples. The results are expressed as the average \pm standard deviation concentration (w/v). 


\subsection{Monitoring oxidation by-products from fried peanuts}

Twenty-five grams of fried peanuts and a $10 \mathrm{~cm} \times 8 \mathrm{~cm}$ piece of the developed films were placed in a $100 \mathrm{~mL}$ glass vial, hermetically closed with a twist-off closure equipped with a sampling port, and stored at $37^{\circ} \mathrm{C}$ for 10 weeks. Vials with no material, named "peanut", and with EVOH without cyclodextrins, named "blank", were prepared in order to check the scalping activity of the pure $\mathrm{EVOH}$ copolymer. The tests were carried out in quintuplicate.

The organic compounds retention of the different films was quantified by gas chromatography with flame ionization detection (GC-FID) at intervals throughout the storage time. A Supelco 65- $\mu \mathrm{m}$ DVB/PDMS solid phase micro extraction (SPME) fiber (Teknokroma, Barcelona, Spain) was exposed to the vial headspace for $45 \mathrm{~min}$ and immediately desorbed for $10 \mathrm{~min}$ in the injector of an HP5890 gas chromatography (Agilent Technologies, Barcelona, Spain) equipped with a $30 \mathrm{~m}, 0.32 \mathrm{~mm}, 0.25 \mu \mathrm{m}$ TRB-MetaX5 capillary column (Teknokroma, Barcelona, Spain). The chromatographic conditions were as follows: $\mathrm{He}$ as the carrier gas, splitless injection, $210^{\circ} \mathrm{C}$ and $300^{\circ} \mathrm{C}$ injector and detector temperatures, $5 \mathrm{~min}$ at $40^{\circ} \mathrm{C}$, first heating ramp to $60^{\circ} \mathrm{C}$ at 3 ${ }^{\circ} \mathrm{C} / \mathrm{min}$, second heating ramp to $200^{\circ} \mathrm{C}$ at $10^{\circ} \mathrm{C} / \mathrm{min}$, and $5 \mathrm{~min}$ at $200^{\circ} \mathrm{C}$.

The volatile compounds were identified in an HP 5890 series II gas chromatograph equipped with an HP 5972 mass-selective detector. The compounds adsorbed by the fibre were desorbed in the injection port of the GC-MS for $10 \mathrm{~min}$ at $210^{\circ} \mathrm{C}$ with the purge valve off (splitless mode). The compounds were separated in a $30 \mathrm{~m}, 0.32 \mathrm{~mm}, 0.25 \mu \mathrm{m}$ TRB-5MS capillary column (Teknokroma, Barcelona, Spain) with the same conditions as in the GC-FID analysis. The compounds were identified by comparison with mass spectra from the library database (NIST 98), and by comparison with authentic standards in both GC-MS and GC-FID. No calibration curves were constructed; therefore the results are expressed as peak area units.

The aldehyde uptake was analyzed with a Dynatherm Thermal Desorber (Supelco, Teknokroma, Spain) connected in series to the column of an 
HP5890 gas chromatograph (Agilent Technologies, Barcelona, Spain) via a heated transfer line. At the end of the storage time, a cut piece of the film was inserted into an empty desorption tube. The tube was placed in the desorber chamber, which was immediately sealed. The desorption conditions were: desorption temperature $180{ }^{\circ} \mathrm{C}$, transfer line $180^{\circ} \mathrm{C}$, desorption time $300 \mathrm{~s}$. The GC was equipped with a TRB5 $(30 \mathrm{~m}, 0.32 \mathrm{~mm}, 0.25 \mu \mathrm{m})$ column (Teknokroma, Barcelona, Spain) and a flame ionization detector. After the analysis, the film sample was recovered from the desorption tube and weighed on an analytical balance. The Desorber-GC was calibrated by measuring film samples with known amounts of each aroma (measured independently by gravimetry).

\subsection{Statistical analysis}

One-way analyses of variance were carried out using the SPSS computer program (SPSS Inc., Chicago, IL, USA). Differences in pairs of mean values were evaluated by the Tukey-b test for a confidence interval of $95 \%$. The data are represented as average \pm standard deviations.

\section{RESULTS AND DISCUSSION}

In a previous characterization study of $\mathrm{EVOH}$ films containing betacyclodextrin the level of immobilization was measured by determining the global migration values of the polymer into water (Lopez de Dicastillo et al., 2010). This analysis revealed that films with $20 \%$ and $30 \%$ of cyclodextrins released approximately $12 \%$ and $14 \%$ of their weight respectively after one day's immersion in water. Similar values were measured after ten days of storage, indicating a non-diffusion controlled migration process. Since the release of glycerol in the control samples was below $2 \%$, approximately $10 \%$ and $18 \%$ of $\beta C D$ are actually immobilized in the EVOH film matrix. Film transparency was evaluated through the Kubelka-Munk K/S coefficient, defined as the ratio between light absorption and scattering and the internal transmittance of the film (Ti). An increase in $\mathrm{K} / \mathrm{S}$ or Ti can be assumed as an increase in transparency. 
Figure 6.1 shows the profile of K/S and internal transmittance values as a function of wavelength. As it can be seen, the addition of glycerol reduced the transparency of the film, especially at the lower wavelengths. The incorporation of cyclodextrins results is a slight decrease in the values of $\mathrm{K} / \mathrm{S}$ that increases with the wavelengths. This result appears to indicate that the presence of the cyclodextrins in the matrix reduces transparency by increasing light scattering. Nevertheless, this decrease is not so relevant when expressed as internal transmittance. Ti values for pure $\mathrm{EVOH}$ and $\mathrm{EVOH}$-glycerol films are well above $80 \%$ transmittance throughout all the spectra. The incorporation of $20-30 \%$ of cyclodextrins reduced the transmittance in a $10 \%$ at any wavelength. Therefore, the application of the active EVOH-based layer to the packaging structure will imply a reduction in transparency, which will be less noticeable with the reduction of layer thickness.
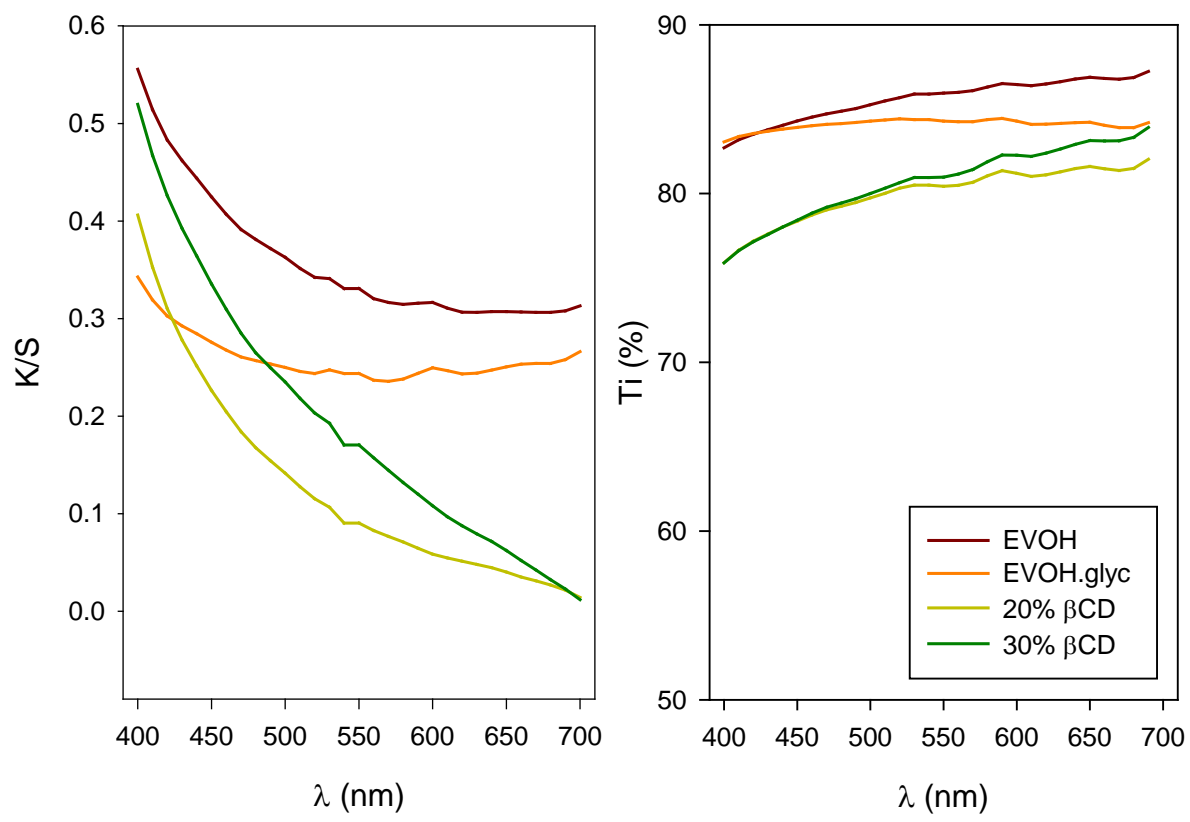

Figure 6.1. Values of the Kubelka-Munk transparency parameter (K/S) and of the internal transmittance (Ti) as a function oof wavelength. 


\subsection{Cholesterol scavenger results}

Firstly, the cholesterol concentration in milk was determined by GC following the method described by Fletouris (Fletouris et al., 1998), using $5 \alpha$-cholestane as the internal standard. The extraction method was tested by measuring the cholesterol content of a known sample; the cholesterol was dissolved in ethanol and then diluted with distilled water to a final cholesterol concentration of $150 \mu \mathrm{g} / \mathrm{mL}$. The results showed the method to have good efficacy, with yields of $95.7 \pm 2.3 \%$. The tests carried out on the milk samples as received yielded concentrations of $151.5 \pm 4.3$ and $161.6 \pm 3.2 \mu \mathrm{g} / \mathrm{mL}$ for the pasteurized and the UHT milk samples, respectively, which are in agreement with data reported in the literature (Valenzuela et al., 2002, Sterna and Jemeljanovs, 2003).

For the first set of experiments was carried out at $4{ }^{\circ} \mathrm{C}$ with pasteurized milk, the results obtained after 2 and 7 days of exposure are presented in Table 6.2. At day two, the milk sample exposed to a film without $\beta C D$ presented a slight reduction that cannot be considered significantly different from the cholesterol level of the control. In contrast, the concentration of cholesterol in the milk exposed to $\beta C D$ containing EVOH samples decreased significantly $(p<0.05)$ with respect to the control sample, although no effect of $\beta C D$ concentration could be observed. Similar results were obtained at day 7 , when the lowest cholesterol concentration values were obtained for the samples exposed to the films containing $\beta C D$, although the reduction in cholesterol concentration was only significant for the sample with the highest $\beta C D$ content. However, the most noticeable variation was that observed with storage time. The presence of cholesterol was significantly lower in all the samples, with the largest variations being found in the control samples. This decrease cannot be attributed to the presence of the EVOH films or to the incorporation of the $\beta C D$. A decrease in the cholesterol concentration in milk during storage can be due to internal milk reactions caused by lactic bacteria of a proteolitic and lipolitic nature (Varnam and Sutherland, 1995). The reason for the smaller reduction measured in the samples with $\beta C D$ could be that complexation 
within the active matrix has a protective effect on the cholesterol molecules. Feigenbaum et al. (1998) described the protective effect of scalping on unstable aroma components in orange juice.

A second set of experiments was carried out with UHT milk at $23^{\circ} \mathrm{C}$. In this assay, the sample with $\mathrm{EVOH}$ films without $\beta C D$ was not included since no scavenging effect by the pure polymer had been observed. As can be seen in Table 6.3, a significant reduction in cholesterol levels was measured for the samples with $\beta C D$ after two days of storage. No differences were observed between samples with $20 \%$ and $30 \%$ of $\beta C D$.

Table 6.2. Cholesterol concentration $(\mathrm{mg} / \mathrm{L})$ and $\%$ of reduction of cholesterol at days 2 and 7 in pasteurized milk exposed to EVOH materials at $4{ }^{\circ} \mathrm{C}$.

\begin{tabular}{c|cc|cc}
\hline & \multicolumn{2}{c}{ Day 2 } & \multicolumn{2}{c}{ Day 7} \\
& Cholesterol & Reduction (\%) & Cholesterol & Reduction (\%) \\
\hline Milk & $151.3 \pm 7.2 \mathrm{a}, \mathrm{x}$ & & $120.5 \pm 5.6 \mathrm{a}, \mathrm{y}$ & \\
Blank & $145.6 \pm 7.0 \mathrm{a}, \mathrm{x}$ & 3.8 & $115.7 \pm 5.4 \mathrm{ab}, \mathrm{y}$ & 4.0 \\
$20 \% \beta C D$ & $130.9 \pm 1.4 \mathrm{~b}, \mathrm{x}$ & 13.5 & $113.5 \pm 4.2 \mathrm{ab}, \mathrm{y}$ & 6.2 \\
$30 \% \beta C D$ & $125.5 \pm 6.9 \mathrm{~b}, \mathrm{x}$ & 17.1 & $110.5 \pm 2.1 \mathrm{~b}, \mathrm{y}$ & 8.3 \\
\hline
\end{tabular}

$a, b, c \ldots$ indicate significant differences in the values of different samples on the same day. $\mathrm{x}, \mathrm{y} \ldots$ indicate significant differences in the values of the same sample on different days.

When compared with the values shown in Table 6.2, the active films presented similar efficiency at the two storage temperatures, with slightly higher values for the pasteurized milk stored at $4^{\circ} \mathrm{C}$.

The behavior of the UHT milk samples was similar on day 7 . The presence of the active films resulted in a significant reduction in cholesterol concentration. The cholesterol scavenging activity increased with the concentration of $\beta C D$ in the film samples. In this test with UHT milk, no reduction of cholesterol with time was observed in the control sample, indicating that the handling of samples in aseptic conditions together with the use of UHT milk reduced the potential influence of lipolitic microorganisms on the results. After a week of exposure, the EVOH material containing 30\% $\beta C D$ had adsorbed nearly $23 \%$ 
of the initial cholesterol content. As mentioned in the introduction, 1:1, 1:2 and $1: 3$ cholesterol/ $\beta C D$ inclusion complexes have been reported in the literature. In this work, the low mobility of the cyclodextrin molecules within the matrix should hinder the formation of inclusion complexes other than 1:1 cholesterol/ $\beta C D$. Most probably, the alquilic chain of the cholesterol molecule is trapped in the $\beta C D$ cavity (see dimensions in Table 6.1). Taking this hypothesis into account and considering that after the washing steps the film samples contained $12 \%$ and $18 \%$ of $\beta C D$, the percentages of $C D$ molecules involved in cholesterol scavenging after 7 days were $15.5 \%$ and $15.7 \%$ for the $20 \% \beta C D$ and $30 \% \beta C D$ samples respectively.

Table 6.3. Cholesterol concentration $(\mathrm{mg} / \mathrm{L})$ and $\%$ of reduction of cholesterol at days 2 and 7 in UHT milk exposed to EVOH materials at $23^{\circ} \mathrm{C}$.

\begin{tabular}{c|cccc}
\hline & \multicolumn{3}{c}{ Day 2 } & \multicolumn{2}{c}{ Day 7} \\
& Cholesterol & Reduction (\%) & Cholesterol & Reduction (\%) \\
\hline Milk & $161.4 \pm 16.4 \mathrm{a}, \mathrm{x}$ & & $152.5 \pm 4.7 \mathrm{a}, \mathrm{x}$ & \\
$20 \% \beta C D$ & $142.8 \pm 2.2 \mathrm{ab}, \mathrm{x}$ & 11.5 & $129.2 \pm 1.2 \mathrm{~b}, \mathrm{x}$ & 15.3 \\
$30 \% \beta C D$ & $140.1 \pm 3.8 \mathrm{~b}, \mathrm{x}$ & 13.2 & $117.2 \pm 5.1 \mathrm{c}, \mathrm{y}$ & 23.2 \\
\hline
\end{tabular}

$a, b, c \ldots$ indicate significant differences in the values of different samples on the same day. $\mathrm{x}, \mathrm{y} \ldots$ indicate significant differences in the values of the same sample on different days.

A reduction in film thickness could accelerate the diffusion of the large cholesterol molecules and increase the scavenging efficiency of the films. No significant differences were observed between the samples containing $20 \%$ $\beta C D$ and $30 \% \beta C D$.

\subsection{Monitoring peanuts oxidative products}

Hexanal is one of the principal volatile compounds formed during lipid peroxidation and its concentration in the package headspace is usually monitored as an index of lipid deterioration. It has been described as the main oxidation product formed from linoleic acid, a polyunsaturated fatty acid present in peanuts, and it is chosen as an indicating chemical for the oxidation 
of peanuts (Han et al., 2008). In the present study, hexanal was the most important volatile component identified by GC-MS in the package headspace over the 10 weeks of storage.

A previous study of the food aroma retention capacity of $\beta C D$ (free and incorporated into EVOH films) showed preferential sorption of compounds with apolar molecules (Lopez de Dicastillo et al., 2010). In that study, exposing a $\beta C D$ containing film to a hydroalcoholic solution resulted in $n$-hexanal retention of up to $40 \%$. The formation of $\beta C D$ inclusion complexes with apolar 'guest' molecules has been described earlier (Goubet et al., 1998; Szente and Szejtli, 2004).

Four sets of samples were studied: peanuts (peanuts), peanuts with an EVOH film without $\beta C D$ to measure the scalping effect of the pure copolymer (blank), peanuts with a film sample containing $20 \%$ of $\beta C D(20 \% \beta C D)$ and peanuts with a film sample containing $30 \%$ of $\beta C D(30 \% \beta C D)$. Figure 6.2 shows the evolution of the hexanal concentration in the bag headspace of all the samples over the storage time. As can be seen, the amount of hexanal in the internal atmosphere of the peanuts samples increased rapidly and steadily with time till week eight. From that moment, the concentration of hexanal in the packaged headspace remained constant. This could be caused by a reduction in the release of hexanal and/or because a partition equilibrium between the fried peanuts and the internal atmosphere had been reached. The blank samples presented a similar profile. However, the hexanal concentration in the samples containing $\beta C D$ increased at a significantly slower pace $(p<0.05)$ than in the peanuts and blank samples. 


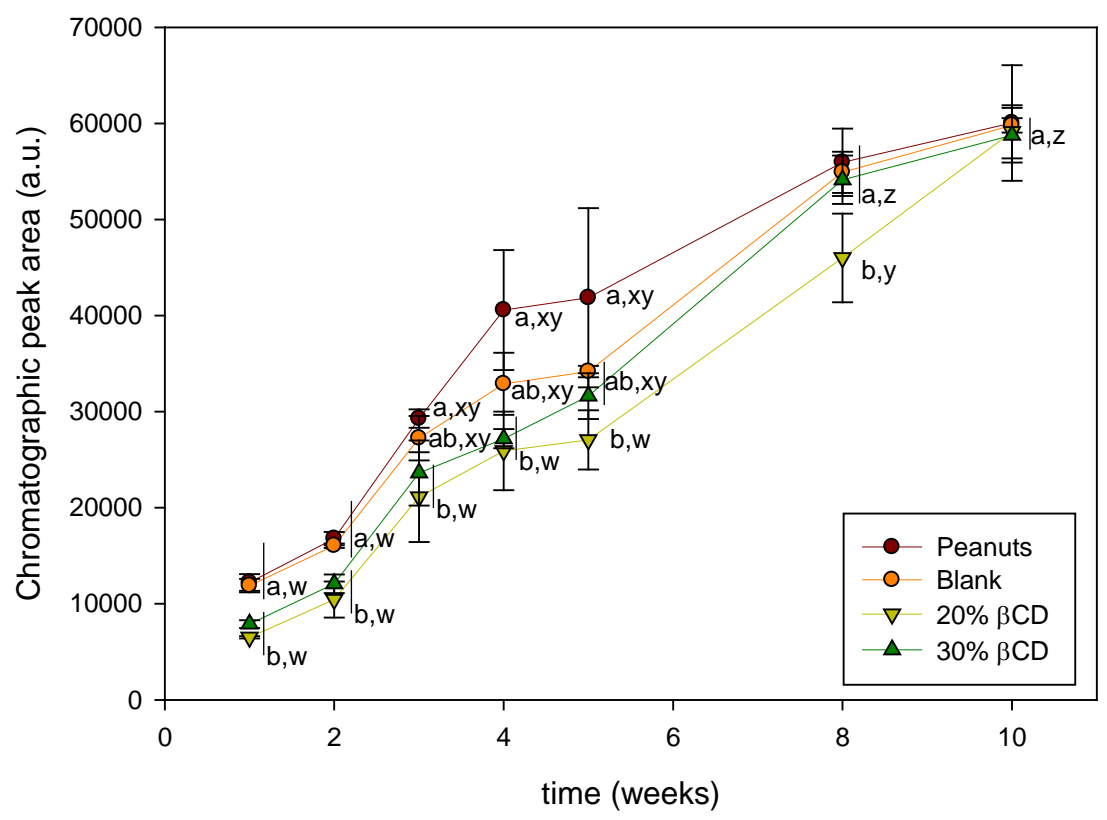

Figure 6.2. Hexanal concentration evolution over storage time. A, b and c indicate significant differences in the values of different samples on the same day; $x$ and $y$ indicate significant differences in the values of the same sample on different days.

This difference can be attributed to the presence of $\beta C D$ and the formation of inclusion complexes, since the sample with pure EVOH (blank) did not present significant differences with respect to the peanuts sample. During the first two weeks of storage, the concentration of hexanal in the samples with $\beta C D$ was half that of the control samples. This reduction continued up to week 5 , when the concentration of hexanal in all the samples increased to similar values. At weeks 9 and 10 no significant differences between samples were observed, possibly because the scavenging capacity of the films had been exhausted.

Additionally, more volatile compounds in the headspace were identified as pentanal, heptanal, 2-heptenal, octanal and 2-octenal. These could be the result of degradation of the vegetable oils used in the frying process. Chung et al. (1993) and Guillen and Ruiz (2005) reported that the main aldehydes 
generated by oxidation of frying oils were 2-alkenals and n-alkanals. The evolution of these aldehydes is shown in Figure 6.3.

As expected, the concentration of all five compounds increased over the storage time in all the samples. Also, in all the cases the compound formation slope was higher after the fourth week. With respect to the effect of the materials, the results showed that those containing $\beta C D$ presented the expected scavenging activity, significantly reducing the concentration of all aldehydes after the first week. At the tenth week, the reductions on pentanal, heptanal and 2-octenal concentrations were 28,33 and $56 \%$ in the case of the films with $20 \% \beta C D$, and 21,22 and $48 \%$ in the case of films with $30 \% \beta C D$, respectively, being the effect of $\beta C D$ concentration in the film not statistically significant on the concentration of aldehydes measured at the package headspace.

This result might be a consequence of partition equilibria that occur in the active film/food/headspace system and that can minimize the effect of scavenging on the measured concentrations at the headspace.

These results prove that these EVOH films presented the expected activity in reducing the concentration of apolar compounds in the package headspace. Since the blank samples did not show any noticeable scalping activity, the formation of inclusion complexes with the $\beta C D$ molecules appears to be the most plausible action mechanism. As can be seen in Table 6.1, all mentioned aldehydes present a maximum diameter below that of the $\beta C D$ cavity. 

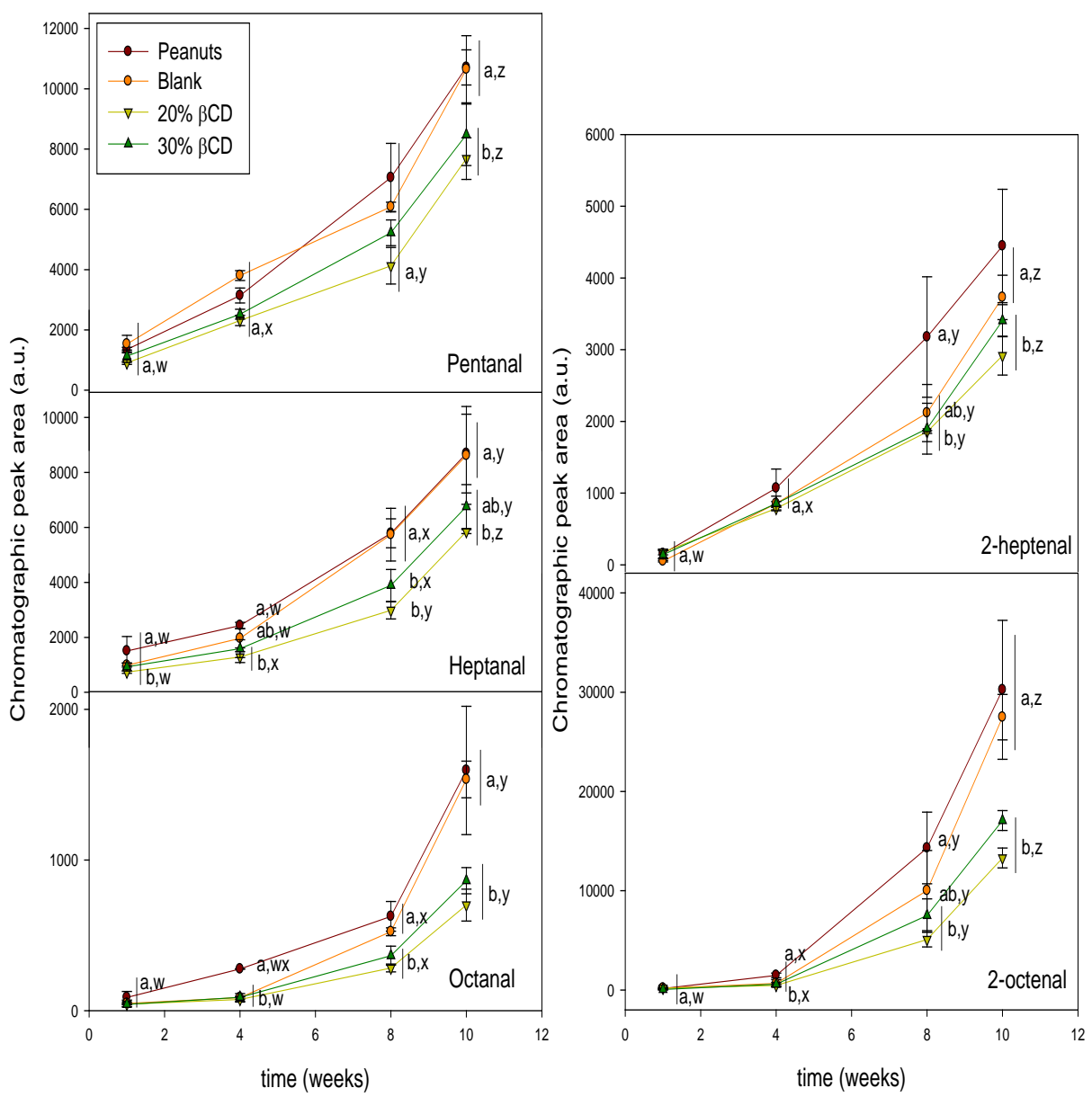

Figure 6.3. Concentration evolution of pentanal, heptanal, 2-heptenal, octanal and 2octenal, over storage time. $\mathrm{a}, \mathrm{b}$ and $\mathrm{c}$ indicate significant differences in the values of different samples on the same day; xand y indicate significant differences in the values of the same sample on different days.

To measure the actual amount of aldehydes retained by the film samples at the end of the storage period, the film was analyzed with a thermal desorber coupled to a GC. Unfortunately, separation of the different aldehydes could not be achieved and the chromatogram showed a wide peak. Since the calibration 
factors of the compounds were similar, with differences between constant values below $10 \%$ and molecular weights within a $10 \%$ range, hexanal (the main compound) was considered the only aldehyde present in the film. The results showed that the blank film retained $0.37 \pm 0.10 \mathrm{mg}$ of hexanal per $\mathrm{g}$ of polymer. The $20 \% \beta C D$ and the $30 \% \beta C D$ samples retained significantly higher amounts: $12.3 \pm 0.3$ and $15.4 \pm 0.3 \mathrm{mg} / \mathrm{g}$. Taking into consideration the actual $\beta C D$ concentrations in these films (10\% and $18 \%)$ and the formation of $1 / 1$ aldehyde/ $\beta C D$ inclusion complexes, the percentage of cyclooligosaccharides involved in the scavenging processes were $115 \pm 23 \%$ and $97 \pm 15 \%$ for the $20 \% \mathrm{CD}$ and $30 \%$ CD samples respectively. This result confirmed that the cyclodextrins were successfully incorporated into the EVOH films, with the internal cavity available for the retention of apolar organic compounds and that the films with 30\% CD retained higher amounts of aldehydes than those containing $20 \%$ even though it was not noticeable in the measured aldehyde concentrations in the headspace. The high polarity of the EVOH polymer segments appeared to interact only with the polar external surface of the oligosaccharides. The smaller molecular size of these aldehydes (see Table 6.1) compared to the cholesterol molecules increased the availability of $\beta C D$ for the formation of inclusion complexes.

\section{CONCLUSIONS}

This study explored the capacity of EVOH films containing $\beta$-cyclodextrins to retain undesirable substances present in food or in the surrounding headspace. The films containing 20 and $30 \%$ of $\beta C D$ successfully retained cholesterol from pasteurized and UHT milk at 4 and $23^{\circ} \mathrm{C}$, respectively. To check their applicability to scavenging oxidative byproducts, these films were also tested with fried peanuts. As expected, the inclusion of $\beta C D$ in the EVOH films resulted in a lower aldehyde concentration in the package headspace. Similar applications of EVOH- $\beta \mathrm{CD}$ films can be derived to retain undesired apolar compounds. Other potential applications could be to reduce migration by retaining apolar migrants within the film structure, or to incorporate active agents or functional components into the film in the form of inclusion 
complexes which would protect them during package manufacture and then release them into the food product.

\section{ACKNOWLEDGEMENTS}

The authors acknowledge the financial support of the Spanish Ministry of Science and Innovation, projects AGL2006-02176, AGL2009-08776 and Fun-

C-Food CSD2007-00063, and the C. L-d-D fellowship (FPU program). Mary Georgina Hardinge provided assistance with the English language text.

\section{REFERENCES}

Almenar, E., Auras, R., Rubino, M., \& Harte, B. (2007). A new technique to prevent the main post harvest diseases in berries during storage: Inclusion complexes betacyclodextrin-hexanal. International Journal of Food Microbiology, 118, 164-172.

Astray, G., Gonzalez-Barreiro, C., Mejuto, J.C., Rial-Otero, R., \& Simal-Gándara, J. (2009). A review on the use of cyclodextrins in foods. Food Hydrocolloids, 23, 16311640.

Burroni, L.V., Grosso, N.R., \& Gurzman, C.A. (1997). Principal volatile components of raw, roasted and fried Argentinean peanut flavors. Journal of Agricultural and Food Chemistry, 45, 3190-3192.

Charles, F., Sanchez, J., \& Gontard, N. (2006). Absorption kinetics of oxygen and carbon dioxide scavengers as part of active modified atmosphere packaging. Journal of Food Engineering, 72, 1-7.

Chung, T. Y., Eiserich, J.P., \& Shibamoto, T. (1993). Volatile compounds identified in headspace samples of peanut oil heated under temperatures ranging from 50 to $200^{\circ} \mathrm{C}$. Journal of Agricultural and Food Chemistry, 41, 1467-1470.

Cravotto, G., Binello, A., Baranelli, E., Carrazo, P., \& Trotta, F. (2006). Cyclodextrins as food additives and in food processing. Current Nutrition \& Food Science, 2, 343350.

Fabra, M.J., Talens, P., \& Chiralt, A. (2010). Influence of calcium on tensile, optical and water vapour permeability properties of sodium caseinate edible films. Journal of Food Engineering, 96, 356-364.

Feigenbaum, A.; Lebossé, R., \& Ducruet, V. Polypropylene as active packaging material for aroma sorption from model orange juice. In Food Flavors: Formation, 
Analysis, and Packaging Influences, No. 40 in Series: Developments in Food Science. Contis, E. T., Ho, C. T., Mussinan, C. J., Parliment, T. H., Shahidi, F., Spanier, A. M., Eds.; Elsevier: Amsterdam, The Netherlands, 1998; pp 743-751

Fletouris, D.J., Botsoglou, N.A., Psomas, I.E., \& Mantis, A.I. (1998). Rapid Determination of Cholesterol in Milk and Milk Products by Direct Saponification and Capillary Gas Chromatography. Journal of Dairy Science, 81, 2833-2840.

Flores, S., Conte, A., Campos, C., Gerschenson, L., \& Del Nobile, M. (2007). Mass transport properties of tapioca-based active edible films. Journal of Food Engineering, 81, 580-586.

Goubet, I., Le Quere, J.L., \& Voilley, A.J. (1998). Retention of aroma compounds by carbohydrates : Influence of Their Physicochemical Characteristics and of Their Physical State. A Review. Journal of Agricultural and Food Chemistry, 46, 19811990.

Guillén, M.D., \& Ruiz, A. (2005). Monitoring the oxidation of unsaturated oils and formation of oxygenated aldehydes by proton NMR. European Journal of Lipid Science and Technology, 107, 36-47.

Han, J.H., Hwang H.M., \& Krochta J.M. (2008). Coating of peanuts with edible whey protein film containing a-tocopherol and ascorbyl palmitate. Journal of Food Science, 73, 349-355.

Hutchings, J.B. (1999). Food colour and appearance, 2nd edn, Kluwer Academic/Plenum Publishers, London.

López-Carballo, G., Cava, D., Lagarón, J.M., Catalá, R., \& Gavara, R. (2005). Characterization of the interaction between two food aroma components, $\alpha$-pinene and ethyl butyrate, and ethylene-vinyl alcohol copolymer (EVOH) packaging films as a function of environmental humidity. J. Agric. Food Chem., 53, 7212-7216.

López de Dicastillo, C., Gallur, M., Catalá, R., Gavara, R., \& Hernandez-Muñoz, P. (2010). Immobilization of $\beta$-cyclodextrin in ethylene-vinyl alcohol copolymer for active food packaging applications. Journal of Membrane Science, 353, 184-191.

López-Rubio, A., Almenar, E., Hernandez-Muñoz, P., Lagarón, J. M., Catalá, R., \& Gavara, R. (2004). Overview of active polymer-based packaging technologies for food applications. Food reviews international, 20, 357-387.

Schroder, B.G., \& Baer, R.J. (1990). Utilization of cholesterol-reduced milk fat in fluid milks. Food Technology, 44, 145-150.

Sterna, V., \& Jemeljanovs, A. (2003). Comparison of fatty acids and cholesterol content in the milk of Latvian cows. Veterinarija ir Zootechnika, 22, 95-98.

Szejtli, J. (1982). Cyclodextrin in Food, cosmetics and toiletries. Starch, 34, 379-385. 
Szente, L., \& Szejtli, J. (2004). Cyclodextrins as food ingredients. Trends in Food Science\&Technology, 15, 137-142.

Valenzuela, A., Sanhueza, J., \& Nieto, S. (2002). Cholesterol oxides (oxisterols): factors conditioning their formation, biological effects and content in foods. Revista Chilena de Nutrición, 29, 116-124.

Varnam, A.H. \& Sutherland, J.P. (1995). Leche y productos lácteos. Tecnología, química y microbiología. Ed. Acribia, S.A. Zaragoza.

Wambura, P., \& Yang, W.W. (2010). Ultrasonication and edible coating effects on lipid oxidation of roasted peanuts. Food Bioprocess Technology, 3, 620-628.

Williams, J.P., Duncan, S.E., Williams, R.C., Mallikarjunan, K., Eigel III, W.N., \& O'Keefe, S.F. (2006). Flavors fade in peanuts during short-term storage. Journal of Food Science, 71, 265-269.

Yamamoto, S., Kurihara, H., Mutoh, T., Xing X., \& Unno, H. (2005). Cholesterol recovery from inclusion complex of $\beta$-cyclodextin and cholesterol by aeration at elevated temperatures. Biochemical Engineering Journal, 22, 197-205. 
Artículo 7

\title{
DEVELOPMENT OF ACTIVE POLYVINYL ALCOHOL/ $\beta$ - CYCLODEXTRIN COMPOSITES TO SCAVENGE UNDESIRABLE FOOD COMPONENTS
}

\author{
Carol López-de-Dicastillo, María Jordá, Ramón Catalá, \\ Rafael Gavara, Pilar Hernández-Muñoz
}

Submitted to Journal of Agricultural and Food Chemistry 



\section{ABSTRACT}

Active food packaging systems based on the incorporation of agents into polymeric package walls are being designed to purposely release or retain compounds to maintain or even increase food quality. The objective of this work was to develop polyvinyl alcohol (PVOH)/ $\beta$-cyclodextrin $(\beta C D)$ composite films which can be applied to reduce undesirable component content such as cholesterol in foods through active retention of the compounds in the package walls during storage. Cyclodextrins were added to $\mathrm{PVOH}$ in a proportion of 1:1, and crosslinked with glyoxal under acidic media to reduce its watersoluble character. Three different crosslinking procedures were used: crosslinking of the polymer/polysaccharide mixture in solution and film casting, $(P \vee O H . ~ \beta C D)^{*}$; crosslinking of the polymer, addition of $\beta C D$, and casting of the mixture, $\mathrm{PVOH}^{*} . \mathrm{CD}$; and casting of a $\mathrm{PVOH}$ film, addition of a $\beta C D / g l y o x a l$ solution onto the film, and crosslinking during drying, PVOH.CD*. The characterization studies showed that the $\mathrm{PVOH}^{*} . \mathrm{CD}$ and $\mathrm{PVOH} . \mathrm{CD}^{*}$ films provided the best physical characteristics with the lowest release values and the highest barrier properties. As a potential application, materials were tested as potential cholesterol scavenging films. There was a significant reduction in the cholesterol concentration in milk samples when they were exposed to the materials developed.

Keywords: $\beta$-cyclodextrin, polyvinyl alcohol, active material, composites, crosslinking, cholesterol, scavenger 


\section{INTRODUCTION}

The development of active materials, defined as those that are designed to produce a beneficial interaction with matter, are at the forefront of materials research in applications such as chromatographic fillers, membranes, active packaging, etc. This latter technology is presently focusing the attention of the food industry, since, in combination with other non-thermal technologies, it can improve the quality and safety of food products. Active packaging materials are designed to deliberately incorporate components that would release or absorb substances into or from the packaged food or the environment surrounding the food.

$\beta$-cyclodextrin ( $\beta C D)$ is a cyclic oligosaccharide composed of seven glucose units with a ring structure characterized by a hydrophilic external surface and a hydrophobic cavity. This unique structure enables CD molecules to form inclusion complexes, entrapping all or part of a 'guest' molecule inside their cavities, presenting a potential interest as agents to retain or release entrapped substances. Food ingredients, bioactive compounds, or flavor compounds can be complexed by CDs to protect them against oxidation, lightinduced reactions, heat-promoted decomposition, loss by volatility, or sublimation, or to reduce undesired tastes/odors (Cevallos et al., 2010; Reineccius et al., 2002; Szente and Szejtli, 2004). Empty $\beta C D$ is also being used in the food industry to entrap or remove undesirable compounds such as bitter components from coffee and tea (Yu, 1988), although reducing cholesterol in food is probably the main commercial use of $\beta C D$ in the food sector (Comini and Mentink, 1994).

Several applications have been described in which cyclodextrins or cyclodextrin derivatives have been immobilized in different polymeric supports as membranes for separation of mixed components (Kusumocahyo et al., 2004; Lue and Peng, 2003; Touil et al., 2008; Xiao and Chung, 2007). Most of these membranes were prepared by solution/casting and various crosslinking agents were added to immobilize the oligosaccharides. 
In a previous study, $\beta C D$ was immobilized in an ethylene-vinyl alcohol copolymer film by conventional extrusion (Lopez-de-Dicastillo et al., 2010). The resulting materials presented scavenging activity of apolar substances. This activity was also studied for its potential use in the active packaging of food (López de Dicastillo et al., 2011).

Polyvinyl alcohol (PVOH) is a water soluble, partially crystalline polymer, with technological potential as a biodegradable material (De Prisco et al., 2002; ElKader et al., 2002). This polymer has excellent film-forming, emulsifying, and adhesive properties. It is odorless and nontoxic in many applications (DeMerlis and Schoneker, 2003; Kelly et al., 2003). It has high tensile strength and flexibility, as well as high oxygen and aroma barrier properties. Nevertheless, these properties are dependent on humidity. Water, which acts as a plasticizer, reduces its tensile strength, but increases its elongation and tear strength. $\mathrm{PVOH}$ has a high water permeation rate, and it is completely hydrosoluble unless it is crosslinked. Several multifunctional compounds capable of reacting with the hydroxyl group may be used as a crosslinker (Gohil et al., 2006).

The objective of this work was to develop materials based on polyvinyl alcohol containing cyclodextrins which were resistant to water and applicable to the reduction of undesirable component content such as cholesterol in food through active retention of the compounds in the package walls during storage. To reduce the water soluble character of $\mathrm{PVOH}$, the $\mathrm{CD} /$ polymer composites were crosslinked with glyoxal under acidic media. The effect on the final properties of the order of addition of the different components and of the crosslinking process was analyzed. The final materials were characterized by the determination of $C D$ immobilization, glyoxal migration, thermal, barrier, and morphological properties. As an example of the capacities of the materials developed in active packaging, their application in the reduction of cholesterol content in food was also studied. 


\section{MATERIALS AND METHODS}

\subsection{Chemicals and Reagents}

Gohsenol type AH-17 (saponification degree $97-98.5 \%$ mol and viscosity 25$30 \mathrm{mPa}$.s) polyvinyl alcohol (PVOH) was obtained from The Nippon Synthetic Chemical Company (Osaka, Japan). $\beta C D$ was purchased from Wacker Fine Chemicals, S.L. (Barcelona, Spain). Glyoxal 40\% solution in water, hydrochloric acid 37\%, and orthophenylenediamine (OPD) were obtained from Sigma (Madrid, Spain). Reagent-grade hexane and methanol were from Merck (Barcelona, Spain). Cholesterol, 5a-cholestane, and potassium hydroxide were obtained from Fluka Biochemika (Sigma, Madrid, Spain). Water was obtained from a Milli-Q Plus purification system (Millipore, Molsheim, France). Whole UHT milk (Hacendado, Mercadona, Valencia, Spain) was acquired from a local supermarket.

\subsection{Film Preparation}

Films of PVOH containing $\beta$-cyclodextrin were obtained by solution-extensionevaporation ("casting"). This technique has the advantage of reducing thermal degradation of the composite with respect to conventional extrusion and can be compared to film coating techniques.

$\mathrm{PVOH}$ solution (5\% w/v) was prepared in Millipore water by heating it at $85-90$ ${ }^{\circ} \mathrm{C}$ with constant stirring for two hours. The solution was allowed to cool and the film was cast on a flat PS surface. Films of ca. $50 \mu \mathrm{m}$ were obtained. PVOH.CD composite films (1/1 w/w) were obtained by adding a $\beta C D$ solution $(10 \% \mathrm{w} / \mathrm{v})$ to the $\mathrm{PVOH}$ solution, stirring the mixture for $30 \mathrm{~min}$, and film casting (PVOH.CD sample).

To improve the water resistance of the $\mathrm{PVOH}$ films and composites, the polymer was crosslinked with glyoxal (Gohil et al., 2006) by various procedures. In this work, crosslinked materials are marked with an asterisk $\left(^{\star}\right)$. $5 \% \mathrm{w} / \mathrm{w}$ of glyoxal with respect to the weight of $\mathrm{PVOH}$ and $\mathrm{HCl}$ was added to the PVOH solution (to adjust $\mathrm{pH}$ to 3.5 ) and it was heated to $75^{\circ} \mathrm{C}$ for an 
additional two-hour period. The crosslinked $\mathrm{PVOH}$ film ( $\mathrm{PVOH}^{*}$ sample) was obtained from this solution by casting.

In a first development, a $\beta C D$ solution $(10 \% \mathrm{w} / \mathrm{v})$ was added to the previously crosslinked $\mathrm{PVOH}$ solution. This mixture was then stirred for $30 \mathrm{~min}$ and the film was cast ( $\mathrm{PVOH}^{*}$.CD sample). In a second development, glyoxal and $\mathrm{HCl}$ were added to the aqueous solution containing $\mathrm{PVOH}$ and $\beta C D$, and heated to $75{ }^{\circ} \mathrm{C}$ for two hours. The crosslinked film was obtained by casting $\left((\mathrm{PVOH} . \mathrm{CD})^{\star}\right.$ sample). In a third development, a water solution containing the cyclodextrins $(10 \% \mathrm{w} / \mathrm{w})$, glyoxal, and $\mathrm{HCl}$ was added over a cast film of $\mathrm{PVOH}$ and allowed to dry. Crosslinking occurred during the drying process to obtain the PVOH.CD* sample. In all the developments, the PVOH/ $\beta C D$ ratio was $1 / 1(\mathrm{w} / \mathrm{w})$ and casting was carried out in a chamber at $40^{\circ} \mathrm{C}$ and $15 \% \mathrm{RH}$. The final films were ca. $65 \mu \mathrm{m}$ thick.

\subsection{Immobilization studies}

A study of $\beta C D$ release from the films was carried out by determining the global migration from the polymer into water as aqueous food simulant following EU regulations (UNE-EN 1186-3) (Grob et al., 2007). A piece of each developed film was immersed in Millipore water, at a relation of $6 \mathrm{dm}^{2} / \mathrm{L}$, for a period of 10 days at $40^{\circ} \mathrm{C}$, and the global migration values were determined at day 1 and day 10 by calculating the weight loss according to the method prescribed in the applicable EC directives (European Economic Community, 1989, 1990; Garde et al., 1998). All the samples were measured in triplicate.

Simultaneously, the amount of glyoxal released from the materials into water (as food simulant for aqueous food products) was also analyzed by HPLC after derivatization with orthophenylenediamine (OPD) (Mavric et al., 2008; Weigel et al., 2004). $3.0 \mathrm{~mL}$ of simulant, or standard solutions of glyoxal, were mixed with $1.8 \mathrm{~mL}$ of a $0.5 \% \mathrm{w} / \mathrm{v}$ solution of OPD in Milli-Q water. The mixture was kept at room temperature in the dark for 12 hours. After membrane filtration $(0.45 \mu \mathrm{m})$, samples were subjected to chromatographic analysis using an Agilent Technologies 1200 Series HPLC equipped with an Eclipse XDB-C18 
column ( $4.6 \times 150 \mathrm{~mm}, 5 \mu \mathrm{m}$ particle size). The mobile phases were $0.15 \%$ acetic acid (solvent A) and $80 \%$ methanol containing $20 \%$ solvent $A$ (solvent B). The gradient started with $20 \%$ solvent B over a period of $2 \mathrm{~min}$, then it was changed linearly to $40 \%$ solvent B over a period of $20 \mathrm{~min}$ and to $100 \%$ solvent $B$ over a period of $5 \mathrm{~min}$, maintained for 5 minutes, and then changed to $20 \%$ solvent $B$ for $5 \mathrm{~min}$. The flow rate was $0.8 \mathrm{~mL} / \mathrm{min}$ and the column temperature was set at $30^{\circ} \mathrm{C}$. Peaks were detected by measurement of UVabsorbance at $312 \mathrm{~nm}$. A calibration using standard glyoxal solutions in the $0.5-10 \mathrm{mg} / \mathrm{kg}$ range was performed.

\subsection{Swelling assays}

A crosslinked $\mathrm{PVOH}^{*}$ blank and materials with cyclodextrin materials were accurately weighed and placed in a $100 \mathrm{ml}$ glass vial with $70 \mathrm{~mL}$ of water. The samples were removed after one day, cleaned with soft paper to remove surface water, and weighed. Films were dried in a vacuum oven (Heraeus, Germany) at $50^{\circ} \mathrm{C}$ for two days and weighed. The degree of swelling was calculated as the water uptake (difference between wet and dry weights) per $100 \mathrm{~g}$ of dry sample.

\subsection{Fourier Transform Infrared Spectroscopy (FTIR)}

Fourier Transform Infrared Spectroscopy (FTIR) was used to characterize the presence of specific chemical groups in the materials. Very thin $(5-10 \mu \mathrm{m}$ thick) PVOH films were obtained and analyzed by FTIR using Transmittance Mode. FTIR spectra were obtained in the range from 4000 to $500 \mathrm{~cm}^{-1}$, with a resolution of $2 \mathrm{~cm}^{-1}$ and 64 scans (Bruker Tensor 27 equipment).

$\mathrm{PVOH}-\beta C D$ composites were characterized by Attenuated Total Reflection FTIR (ATR-FTIR). Spectra were also obtained in the range from 4000 to 600 $\mathrm{cm}^{-1}$, with a resolution of $4 \mathrm{~cm}^{-1}$ and 64 scans per test. Results were recorded in duplicate. 


\subsection{Thermal analysis}

Thermal properties were determined with a DSC Model Q2000 from TA Instruments (New Castle, DE, USA). Thermograms were obtained from 25 to $250{ }^{\circ} \mathrm{C}$ with a $10{ }^{\circ} \mathrm{C} / \mathrm{min}$ heating ramp. The glass transition temperature, melting temperature, and melting enthalpy were calculated using the TA Universal Analysis software.

Thermogravimetric analyses were also carried out using a Mettler Toledo TGA/SDTA/851 thermal analyzer (Columbus, OH, USA). The samples were heated from room temperature to $600{ }^{\circ} \mathrm{C}$ under a nitrogen atmosphere to determine any evaporation of volatile compounds, as well as the degradation temperatures of the new materials.

\subsection{Barrier Properties}

\subsubsection{Water vapor permeability (WVP)}

WVP tests were carried out at $35,50,60$, and $70 \% \mathrm{RH}$ and $23{ }^{\circ} \mathrm{C}$ using a PERMATRAN-W model 3/33 Mocon (Lippke, Neuwied, Germany). The film samples were conditioned in the cells for ten hours, and then the transmission values were determined every 45 minutes.

\subsubsection{Oxygen permeability}

The oxygen permeation rates of the materials were determined at 50,75 , and 90\% RH and $23^{\circ} \mathrm{C}$ using an OXTRAN Model 2/21 ML Mocon (Lippke, Neuwied, Germany). The film samples were conditioned in the cells for ten hours, and then the transmission values were determined every 45 minutes.

\subsection{Milk sample preparation}

Taking into account results from migration tests, films were previously immersed in water for 24 hours to eliminate the amount of CDs and glyoxal that would have been released into the food product, and then dried with a paper tissue. 
To simulate the conditions of a conventional package for pasteurized milk, a piece of film was put in contact with real milk at a surface/volume ratio equivalent to a $1 \mathrm{~L}$ carton box. Approximately $12.8 \mathrm{~cm}^{2}$ of each film was immersed in $20 \mathrm{~mL}$ of pasteurized milk and kept at $23^{\circ} \mathrm{C}$ for one week in a closed vial covered by aluminum foil to avoid any potential light effect. The milk package, films, vials, and milk were handled under sterile conditions to prevent the risk of bacterial contamination and milk spoilage. The experiments were carried out in quintuplicate.

\subsection{Cholesterol analysis}

The determination of cholesterol in milk was carried out by a simple and rapid method based on direct saponification of the samples with methanolic $\mathrm{KOH}$ solution (Fletouris et al., 1998). A $0.3 \mathrm{~g}$ sample of milk was accurately weighed into a sample preparation vial, and $5 \mathrm{~mL}$ of methanolic $0.5 \mathrm{M} \mathrm{KOH}$ solution was added, followed by $40 \mu \mathrm{L}$ of a hexanolic solution of $5 \alpha$-cholestane 1 $\mathrm{mg} / \mathrm{mL}$, as internal standard. The vial was tightly closed, and its contents were vortexed for $15 \mathrm{~s}$. The vial was then immersed in a $75^{\circ} \mathrm{C}$ bath and kept there for 25 min. Several vials with different samples could be handled conveniently by placing them in a wire basket. Following heating, the vials were cooled to room temperature, $1 \mathrm{~mL}$ of water and $5 \mathrm{ml}$ of hexane were added, and the contents were vortexed vigorously for $1 \mathrm{~min}$ and then centrifuged for $3 \mathrm{~min}$ at $1500 \mathrm{rpm}$. An aliquot of the upper phase was injected in a GC analysis.

Total cholesterol was determined on a TRB-STEROL model fused capillary column (30 m x $0.22 \mathrm{~mm} \times 0.22 \mu \mathrm{m})$ (Teknokroma S. Coop. C. Ltda., Barcelona) using an HP5890 Gas Chromatograph (Agilent Technologies, Barcelona) equipped with a flame ionization detector. The chromatographic conditions were as follows: $\mathrm{He}$ as the carrier gas, $4 \mu \mathrm{L}$ sample injection volume, $1 / 20$ split ratio, isothermal running at $285^{\circ} \mathrm{C}$ for 15 minutes, injection port temperature and flame ionization detector temperature at $300{ }^{\circ} \mathrm{C}$. Quantification of cholesterol was done through a 5-point calibration curve with $5 \alpha$-cholestane as internal standard. A linear peak area/concentration response 
$(r=0.998)$ was observed within the tested range $(1-300 \mathrm{mg} / \mathrm{L})$. The analysis was carried out in triplicate and the determination of cholesterol in control/blank samples was done with each batch of test samples. Results are expressed as average \pm standard deviation concentration $(\mathrm{w} / \mathrm{v})$.

\subsection{Statistical analysis}

One-way analyses of variance were carried out. The SPSS computer program (SPSS Inc., Chicago, IL, USA) was used. Differences in pairs of mean values were evaluated by the Tukey-b test for a confidence interval of $95 \%$. Data are represented as average \pm standard deviation.

\section{RESULTS AND DISCUSSION}

Untreated $\mathrm{PVOH}$ and PVOH.CD films, crosslinked $\mathrm{PVOH}^{*}$ and crosslinked $\mathrm{PVOH}$ films containing $\beta C D$ s, that is, $\mathrm{PVOH}^{\star} \cdot \mathrm{CD},(\mathrm{PVOH} . \mathrm{CD})^{\star}$ and $\mathrm{PVOH} . \mathrm{CD}^{*}$, were successfully obtained following the procedures described in the experimental section. All films were transparent and uncolored, without visual presence of discontinuities or $\beta C D$ aggregates, with a thickness of ca. $45 \pm 5 \mu \mathrm{m}$ (polymeric films) and $65 \pm 5 \mu \mathrm{m}$ (composite films).

\subsection{Immobilization of $\beta C D$ s in the polymeric film}

The degree of immobilization of the oligosaccharides in the polymer matrix was determined by a migration study which consisted in immersion of the film samples in water for 10 days at $40{ }^{\circ} \mathrm{C}$ followed by evaluation of global migration and specific glyoxal migration values. The first important observation was that all the films manufactured from crosslinked materials had highly improved water resistance compared to untreated films of $\mathrm{PVOH}$ or $\mathrm{PVOH}$ with $\beta C D$ s, which lost their integrity by exposure to water. This result was an indication of a successful crosslinking process.

Figure 7.1 presents the results from the migration tests. As can be seen, the migration of all the samples was independent of time. This kind of effect 
matches the case of a migration process restricted to the more external zones of the polymeric sample, or a very fast migration process. This latter hypothesis is more plausible, since the film matrix is highly plasticized by

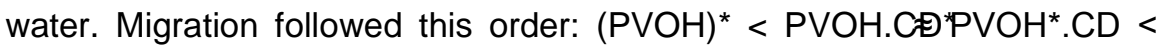
(PVOH.CD)*.

Control $\mathrm{PVOH}^{*}$ samples presented migration values close to $2.1 \%$, and part of this migration corresponded to unreacted glyoxal. The rest could be due to residues and additives from the original $\mathrm{PVOH}$ samples. Unfortunately, noncrosslinked $\mathrm{PVOH}$ film samples could not be tested since the films disintegrated in water.

With respect to migration from samples containing $\beta C D$ s, the highest global migration values (above 25\%) were measured for the $(\mathrm{PVOH} . \mathrm{CD}){ }^{\star}$ sample, that is, when the crosslinking reaction was done with $\mathrm{PVOH}$ and cyclodextrins simultaneously in the crosslinking solution. The presence of $\beta C D$ s probably reduced the $\mathrm{PVOH}$ interchain crosslinking, resulting in a polymeric matrix with low resistance to water.

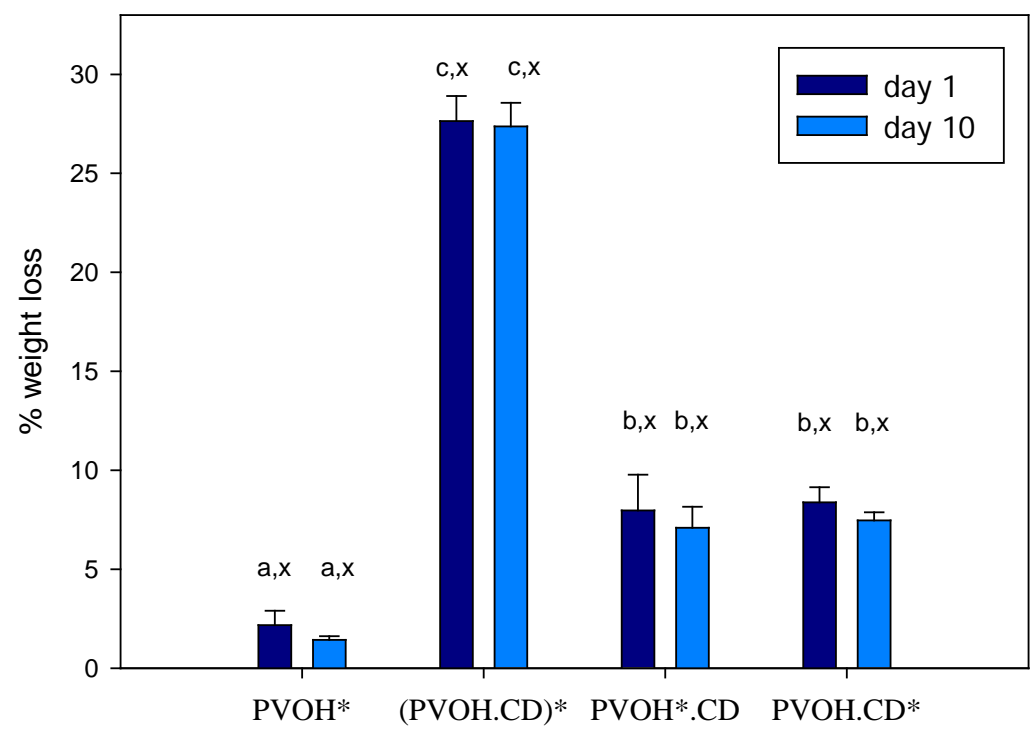


Figure 7.1. Global migration of PVOH layers obtained by casting $(a, b, c, \ldots$ indicate significant differences in migration of the same day between samples, and $x, y, .$. indicate significant differences in migration of the same sample at different days).

As a consequence of the partial disintegration of the matrix, the release of $\mathrm{PVOH}$ molecules together with $\beta \mathrm{CDs}$ and unreacted glyoxal increased the migration values.

In the $\mathrm{PVOH}^{\star} . \mathrm{CD}$, the glyoxal reacted for two hours with the $-\mathrm{OH}$ groups of the polymer and then $\beta C D$ s were added to the solution and films were cast. Efficient crosslinking of the polymer was obtained, resulting in a more stable film that reduced not only the water sensitivity of the film but also the release of oligosaccharides into the aqueous simulant.

The PVOH.CD* samples presented the lowest migration results (no significant differences with respect to $\mathrm{PVOH}^{\star} . \mathrm{CD}$ ). This unexpected result might be a consequence of partial dissolution of the polymeric film in the $\beta C D$ solution and entrance of the crosslinking agent in the film and a crosslinking process that occurs simultaneously with the film drying. Apparently, the addition of the $\beta C D+$ glyoxal solution to the previously cast $\mathrm{PVOH}$ film resulted in severe plasticization/partial dissolution of the PVOH film and transfer of both $\beta C D$ and glyoxal to the film matrix. The reduction of film water content during the reaction may produce a very efficient crosslinking reaction. Otherwise, linkages would have been limited to the $\beta C D$ molecules and the PVOH molecules in the contacting surface, and the bulk of the polymer and the other surface would have been untreated, which would have implied large migration values due to dissolution of $\mathrm{PVOH}$ in the liquid media.

Comparing the migration values of these samples with results from a similar work but using EVOH as polymer matrix (Lopez-de-Dicastillo et al., 2010), PVOH-based materials had lower migration values than EVOH materials obtained by extrusion. In that work, $\beta C D$ s were incorporated by melt mixing during extrusion, that is, immobilization was not achieved by chemical linkages. Since the content of cyclodextrins incorporated in the PVOH films 
was higher and PVOH sensitivity to water is greater, higher $\beta C D$ release results were expected. A possible crosslinking of the $\beta C D$ s to $P V O H$ molecules might be the cause of this greater immobilization.

Among the potential migrants released from the films developed, glyoxal requires a specific migration study. This crosslinking agent is used as a strengthening substance in protein and starch coatings (Code of Federal Regulations, 2001a), and in the production of epoxy resins (Code of Federal Regulations, 2001b). FDA Regulations about Food Contact Substances limit the use of glyoxal to a level not to exceed 6 percent by weight of the starch or protein fraction of the coating solids. The only migration limit detected in these regulations is the specific migration limit of $7.7 \mathrm{mg} / \mathrm{dm}^{2}\left(0.5 \mathrm{mg} / \mathrm{in}^{2}\right)$.

Table 7.1 shows the results of the glyoxal specific migration test, together with data from swelling tests which will be discussed below. The sample of crosslinked polymer released nearly $4.4 \mathrm{mg} / \mathrm{dm}^{2}$ of glyoxal, $15 \%$ of the glyoxal initially added. The $\mathrm{PVOH}^{\star} . \mathrm{CD}$ and $\mathrm{PVOH} . \mathrm{CD}^{*}$ samples had the lowest values, ca. $2 \mathrm{mg} / \mathrm{dm}^{2}$, less than $7 \%$ of the nominal glyoxal addition. This result appears to indicate that $\beta C D$ s were also involved in the reactions of the crosslinking agent.

As can be seen, (PVOH.CD)* was the only sample that exceeded the migration limit. In fact, $40 \%$ of the glyoxal added was released from the film, indicating a very inefficient reaction. The lower concentration of polymer and glyoxal in the mixed solution might be the cause of this effect. For all the materials, no effect of time on migration was observed, probably as a consequence of a very fast migration process, finished during the first 24 hours. 
Table 7.1. Migration of glyoxal $\left(\mathrm{mgr} / \mathrm{dm}^{2}\right)$ in water over time and swelling results.

\begin{tabular}{lccc}
\hline Sample & DAY 1 & DAY 10 & Swelling degree (\%) \\
\hline \hline PVOH $^{*}$ & $4.4 \pm 0.3 \mathrm{~b}$ & $4.1 \pm 0.5 \mathrm{~b}$ & $91.6 \pm 4.8 \mathrm{x}$ \\
PVOH.CD $^{*}$ & $13.1 \pm 1.5 \mathrm{a}$ & $12.7 \pm 0.9 \mathrm{a}$ & $266.3 \pm 24.0 \mathrm{z}$ \\
$\mathrm{PVOH}^{*} . \mathrm{CD}$ & $2.2 \pm 0.1 \mathrm{c}$ & $2.4 \pm 0.2 \mathrm{c}$ & $115.2 \pm 5.9 \mathrm{xy}$ \\
PVOH.CD* $^{*}$ & $2.0 \pm 0.1 \mathrm{~d}$ & $1.8 \pm 0.1 \mathrm{~d}$ & $139.5 \pm 6.6 \mathrm{y}$ \\
\hline
\end{tabular}

$a, b, c, \ldots$ indicate significant differences in migration among the samples at the same day; $x, y, z$ indicate differences in swelling degree among the samples.

\subsection{Swelling results}

Absorption of large quantities of water leads to a reduction of interpolymer interactions, an increase in flexibility of the polymer chain, and, as a consequence of both, a film expansion that directly affects the diffusivity of low molecular weight substances in the matrix and, obviously, the retention capacity of oligosaccharide molecules. Chemical crosslinking of the polymer with glyoxal results in the generation of covalent bonds between $\mathrm{PVOH}$ molecules that maintain the integrity of the polymeric network and reduce polymer chain flexibility and mobility.

Table 7.1 includes the results of the swelling study. Unfortunately, the swelling caused in samples not treated with glyoxal could not be measured owing to the disintegration of the samples in liquid water. Samples containing cyclodextrins presented significantly higher swelling values than crosslinked $\mathrm{PVOH}$, probably as a consequence of the large portion of the film constituted by oligosaccharides (50\%) and the fact that they are hydrophilic and include large cavities which become filled with water molecules when immersed in water. A comparison between the materials containing $\beta C D$ s shows that the $(P V O H . C D)^{\star}$ film samples had the highest swelling values $(p<0.05)$, double the swelling observed for the other two materials, and in agreement with the migration results. No significant differences were observed between 
$\mathrm{PVOH}^{*} . \mathrm{CD}$ and $\mathrm{PVOH} . \mathrm{CD}^{*}$, indicating a similar degree of crosslinking of the composite matrix.

\subsection{Fourier Transform Infrared Spectroscopy (FTIR)}

Infrared spectrophotometry was used to observe the crosslinking effect of glyoxal on the PVOH-based materials. Fig. 7.2 shows the transmission FTIR spectra recorded for the untreated $\mathrm{PVOH}$ and crosslinked $\mathrm{PVOH}^{*}$ films $(5 \mu \mathrm{m}$ thick films were especially prepared). The most relevant features of the $\mathrm{PVOH}$ spectrum are the large, wide $\mathrm{O}-\mathrm{H}$ stretching band $\left(3000-3600 \mathrm{~cm}^{-1}\right)$, the asymmetrical $\left(2941 \mathrm{~cm}^{-1}\right)$ and symmetrical $\left(2907 \mathrm{~cm}^{-1}\right) \mathrm{C}-\mathrm{H}$ stretching bands, the $\mathrm{C}=\mathrm{O}\left(1735 \mathrm{~cm}^{-1}\right)$ and $\mathrm{C}-\mathrm{O}\left(1708 \mathrm{~cm}^{-1}\right)$ stretching bands related to unhydrolyzed acetate groups, the secondary $\mathrm{O}-\mathrm{H}$ in-plane bending band (1426 $\mathrm{cm}^{-1}$ ), the $\mathrm{C}-\mathrm{H}$ wagging vibrations band $\left(1330 \mathrm{~cm}^{-1}\right)$, the $\mathrm{C}-\mathrm{C}-\mathrm{C}$ stretching band $\left(1144 \mathrm{~cm}^{-1}\right)$, and the $\mathrm{C}-\mathrm{O}$ stretching band $\left(1094 \mathrm{~cm}^{-1}\right)$.

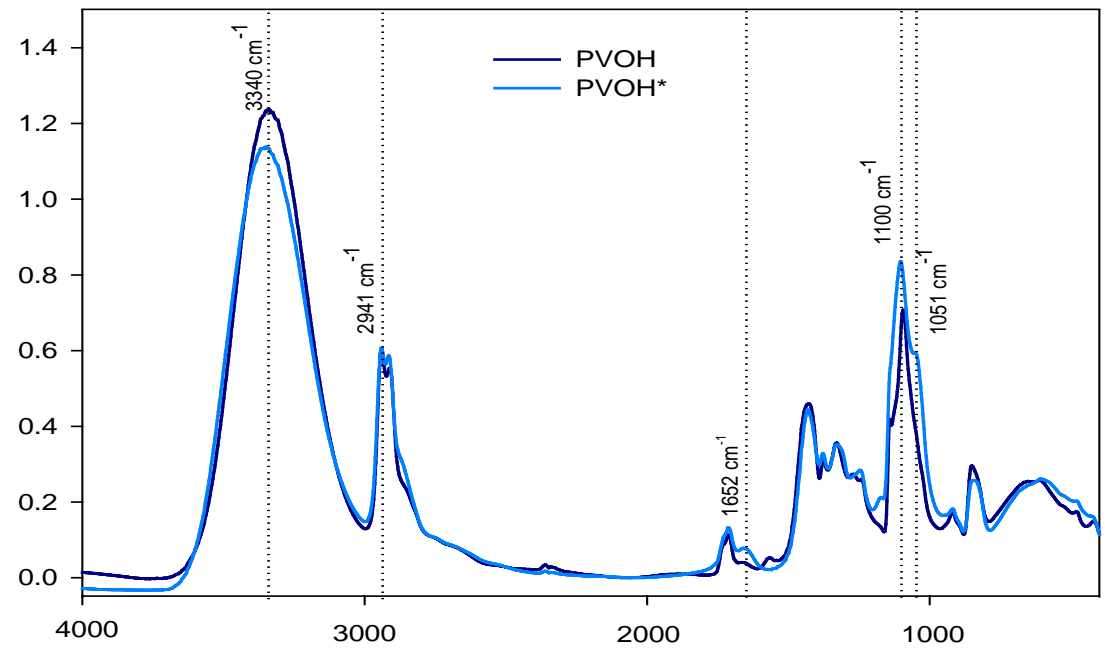

Figure 7.2. Transmission FTIR spectra from untreated $(\mathrm{PVOH})$ and treated $\left(\mathrm{PVOH}^{*}\right)$ polymeric films.

As can be seen, important changes appear with the crosslinking process. As a bi-functional crosslinker, one aldehyde group of the glyoxal molecule reacts with hydroxyl groups of the PVOH polymer chain by forming a hemiacetal structure. Crosslinking occurs by forming acetal bridges between the pendant 
carbonyl group of the glyoxal molecule and hydroxyl groups of another PVOH chain. Therefore, efficient crosslinking implies a reduction of available hydroxyl groups, which was clearly evidenced by the reduction of the relative intensity of the O-H stretching band (3000-3600). The formation of acetal bridges was confirmed by the presence of new features at 1053, 1104, 1180, and $1244 \mathrm{~cm}^{-}$ ${ }^{1}$ related to the presence of ether groups. The presence of a shoulder at ca. $2850 \mathrm{~cm}^{-1}$ related to the stretching of $\mathrm{C}-\mathrm{H}$ in the neighborhood of carbonyl substituents, and the new band at 1652 corresponding to the carbonyl of glyoxal and hemiacetal groups indicated the presence of unreacted glyoxal (Jang et al., 2002). The absence of the peak at $1141 \mathrm{~cm}^{-1}$ indicated the reduction of crystallinity with the crosslinking process (Mansur et al., 2008).

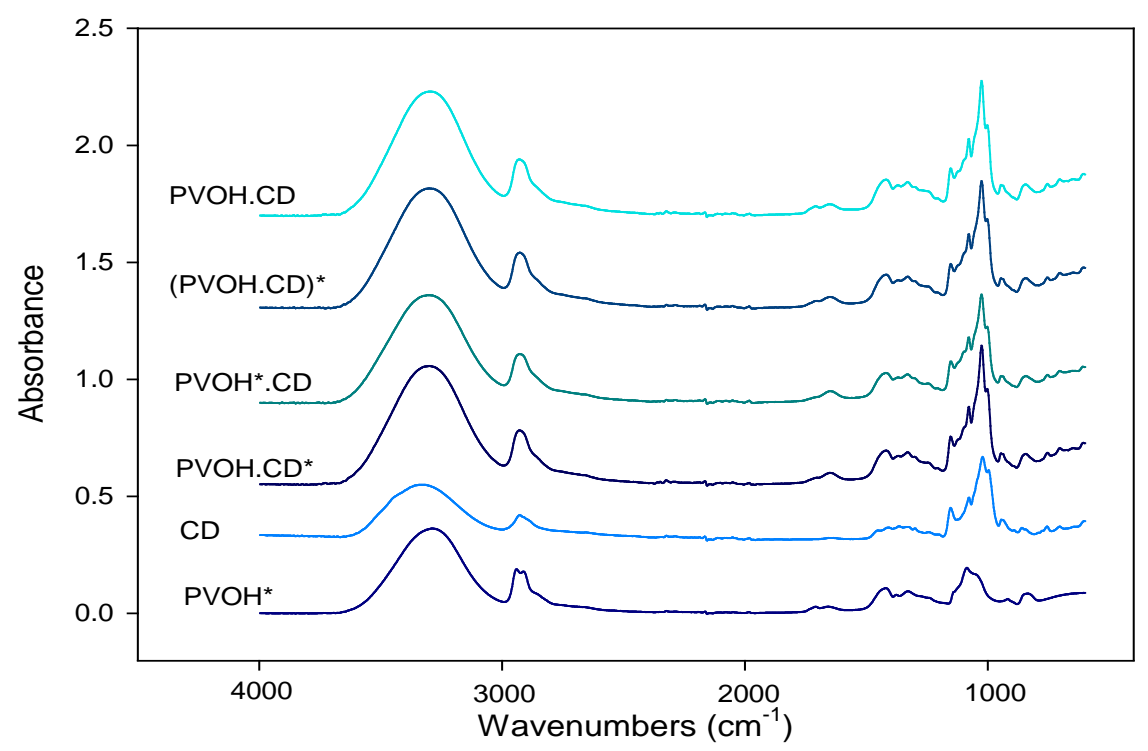

Figure 7.3. ATR-FTIR spectra of PVOH- $\beta C D$ composites and pure components.

Fig. 7.3 shows the ATR-FTIR spectra of $\mathrm{PVOH}^{*}, \beta C D$, and the various composites. The difficulty of obtaining very thin films of $\mathrm{PVOH}$ containing $\beta C D$ s impeded assays in the transmission mode due to superabsorbance. The spectra are displaced on the absorbance axis to facilitate comparison. 
As can be seen, the spectra of the various composites were very similar and practically corresponded to the addition of the $\mathrm{PVOH}^{\star}$ and $\beta \mathrm{CD}$ spectra. The characteristic bands of $\beta C D$ appeared in all spectra at 995, 1003, 1025, 1078, and $1155 \mathrm{~cm}-1$, without any displacement. Moreover, these features within the same wavelength as that of the acetal groups hindered any effect on the $\mathrm{PVOH}$ crosslinking process. The $\mathrm{O}-\mathrm{H}$ stretching band of the composites appeared at intermediate wavenumbers between those of the crosslinked $\mathrm{PVOH}$ and the $\beta C D$.

After the immobilization analysis, the films were dried and analyzed by ATRFTIR. The spectra obtained (not shown) did not exhibit relevant differences with respect to those corresponding to non-migrated films, indicating that the crosslinked films resisted the exposure to water and that the $\beta C D$ s were successfully immobilized.

\subsection{Thermal properties}

The materials developed in this study were analyzed by DSC and TGA. Fig. 7.4 shows representative DSC thermograms of the various film samples. Untreated PVOH showed a glass transition, $\mathrm{T}_{\mathrm{g}}$, at $65.14{ }^{\circ} \mathrm{C}$. This polymer exhibited a clear endotherm between 200 and $230{ }^{\circ} \mathrm{C}$, with a minimum at $220.3^{\circ} \mathrm{C}$ (melting temperature, $\mathrm{Tm}$ ) that reveals the semicrystalline nature of the polymer.

The cooling process (shown in Fig. 7.4) exhibited a crystallization exotherm with a maximum at $189{ }^{\circ} \mathrm{C}$. The other thermograms shown in Fig. 7.4 correspond to crosslinked samples, with and without cyclodextrins, and a noncrosslinked composite film. The clearest effect of crosslinking is the absence of the melting endotherm. The chemical bonding produced by the reaction of glyoxal with the polymer (and possibly with $\beta C D s$ ) impeded the chain rearrangement needed to create crystalline structures. In the cooling process, no signs of crystallization processes were observed. Similar results were observed by Mansur et al. in a $\mathrm{PVOH}$ hydrogel crosslinked with glutaraldehyde (Mansur et al., 2008). The inclusion of the $\beta C D$ s also affected 
the crystallization ability of the polymer in the noncrosslinked sample as observed in the first heating process, although the $\mathrm{PVOH}$ crystallized in the cooling process and presented a melting endotherm in the second heating process.

Table 7.2 shows the glass transition temperatures of the various samples. The addition of $\beta C D$ s yielded greater stiffness, increasing the $T_{g}$ value by about 5 ${ }^{\circ} \mathrm{C}$. The crosslinking process also resulted in an increase in $T_{g}$ since the generation of interchain covalent bonds reduced the flexibility of the polymeric molecules. Similar results have been observed in crosslinked proteins (Hernandez-Munoz et al., 2004; Soares and Soldi, 2010). Incorporation of cyclodextrins produced further increased rigidity of the composite crosslinked materials.

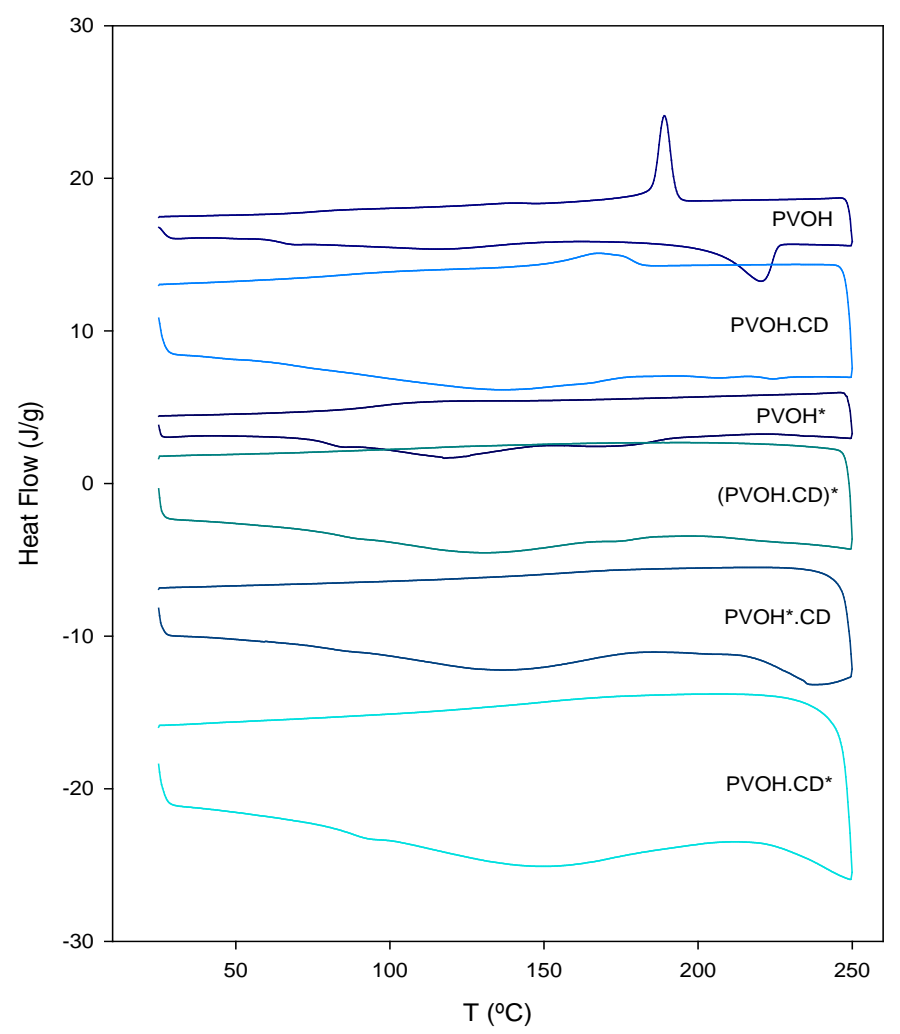

Figure 7.4. DSC thermograms of $\mathrm{PVOH}$ films during the first heating. 
Table 7.2

Thermal properties of the materials developed: glass transition temperatures, dehydration, and degradation peaks expressed as temperature $\left({ }^{\circ} \mathrm{C}\right)$ of the minimum at the derivative and attributed percentage of the weight loss.

\begin{tabular}{|c|c|c|c|c|c|c|c|c|c|}
\hline Material & $\begin{array}{c}T_{g} \\
\end{array}$ & \multicolumn{2}{|c|}{ Dehydration } & \multicolumn{6}{|c|}{ Degradation } \\
\hline Glyoxal & - & 125.9 & $53 \%$ & 152.2 & $10.2 \%$ & 223.4 & $36.8 \%$ & - & - \\
\hline$\beta C D$ & - & 89.3 & $13 \%$ & 330.5 & $87 \%$ & - & - & - & - \\
\hline $\mathrm{PVOH}$ & 65.14 & 113.3 & $1.1 \%$ & 293.7 & $40.7 \%$ & 346.6 & $42.9 \%$ & 433.1 & $15.4 \%$ \\
\hline PVOH.CD & 70.40 & 131.7 & $2.6 \%$ & 325.1 & $28.1 \%$ & 351.1 & $54.9 \%$ & 437.6 & $14.3 \%$ \\
\hline $\mathrm{PVOH}^{*}$ & 80.12 & 118.5 & $3.1 \%$ & 359.6 & $47.4 \%$ & 366.0 & $31.1 \%$ & 442.0 & $18.4 \%$ \\
\hline$(\mathrm{PVOH} . \mathrm{CD})^{*}$ & 84.56 & 127.5 & $3.4 \%$ & 326.6 & $45.3 \%$ & 380.2 & $51.3 \%$ & - & - \\
\hline $\mathrm{PVOH}^{*} . \mathrm{CD}$ & 82.90 & 132.0 & $3.7 \%$ & 309.0 & $35.7 \%$ & 369.0 & $55.6 \%$ & 435.8 & $5.0 \%$ \\
\hline PVOH.CD* & 88.01 & 145.4 & $6.0 \%$ & 304.2 & $40.0 \%$ & 380.4 & $49.3 \%$ & 433.9 & $4.8 \%$ \\
\hline
\end{tabular}

The TGA thermograms showing the weight loss and its derivative with temperature for all the materials and components are plotted in Fig. 7.5. As can be seen, they show that there were several degradation processes. To determine their individual contributions to the mass loss, the wide bands presented in the derivative curve have been deconvoluted using Origin software with Gaussian or Lorentzian fitting. In all cases, a good fit was observed with $\mathrm{R}^{2}>0.99$. The deconvolution of the $\mathrm{PVOH}^{*}$ sample is included as an insert in Fig. 7.5. The results of the various degradation contributions to mass loss are included in Table 7.2.

All samples showed a weight loss at temperatures slightly above $100^{\circ} \mathrm{C}$ which is related to the evaporation of water. The degradation of the $\beta C D$ s appeared in a single narrow feature at $330{ }^{\circ} \mathrm{C}$. Glyoxal also degraded in practically a single process at $223{ }^{\circ} \mathrm{C}$. On the other hand, $\mathrm{PVOH}$ underwent three 
degradation processes, the two more important ones occurring at 294 and 347 ${ }^{\circ} \mathrm{C}$. According to Ballistreri et al. (1980) and Holland and Hay (2001) the degradation of $\mathrm{PVOH}$ starts with the loss of water molecules by elimination of hydroxyl side groups and acetaldehyde, acetone, ethanol, unsaturated aldehydes, and ketones.
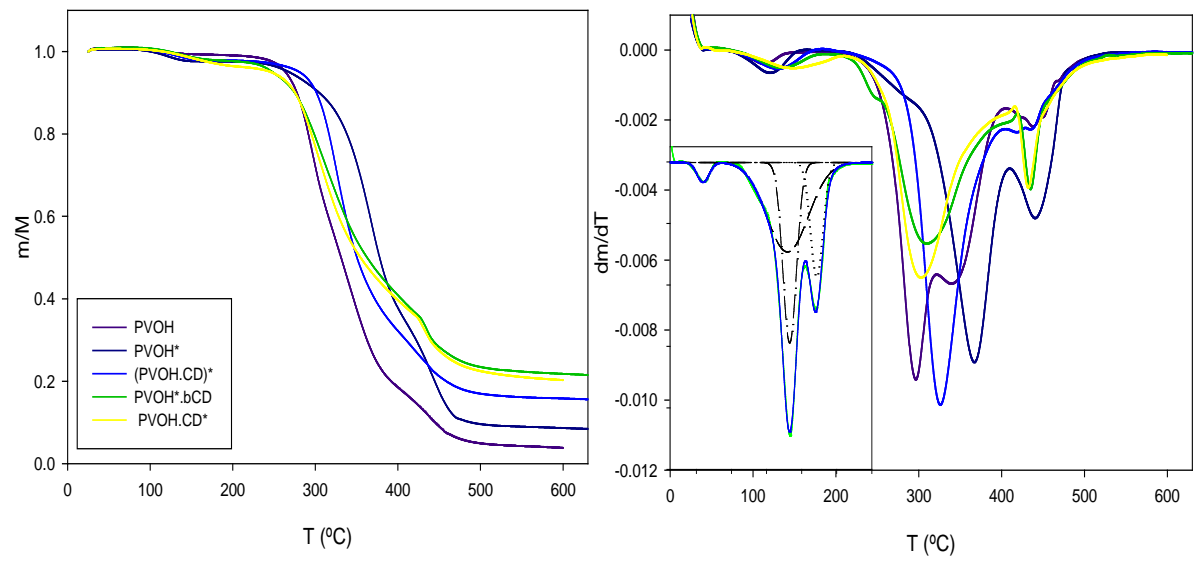

Figure 7.5. TGA and derivative curves of the films developed. Insert: Deconvolution of the TGA derivative curve of $\mathrm{PVOH}^{*}$ material, using a Gaussian algorithm.

At higher temperatures, degradation continues with the breakdown of the polymer backbone and the release of aromatic substances (benzene, naphthalene, and derivatives). A noncrosslinked film of $\mathrm{PVOH}$ containing $\beta C D$ s was prepared and included in this study. This particular sample showed the original TG features of the two components.

As can be seen in Fig. 7.5, the crosslinked samples presented a different thermal behavior. The first degradation process observed from the crosslinked $\mathrm{PVOH}$ sample $\left(\mathrm{PVOH}^{\star}\right)$ took place at $360^{\circ} \mathrm{C}$, well above that of the untreated $\mathrm{PVOH}$. The crosslinking process, which makes use of the $-\mathrm{OH}$ groups, reduces the initiation of the degradation process by dehydration, causing this change. Variations in the temperature of the first and second degradation processes were also observed in all composites. The absence of the 
degradation band of the pure $\beta C D$ (except in the (PVOH.CD) ${ }^{*}$ sample) indicates that the oligosaccharide was involved in the crosslinking process.

\subsection{Barrier property results}

\subsubsection{Water vapor permeability}

The water vapor barrier of a polymer is a very important datum in packaging design. Owing to the hydrophilic character of $\mathrm{PVOH}$, the analysis of the water vapor permeability of the $\mathrm{PVOH}$ samples was carried out at various relative humidity conditions, and the results are included in Table 7.3.

As expected, all the materials showed a strong dependence on the relative humidity. The sorption of large amounts of water caused an increase in polymer chain mobility and, consequently, in water diffusivity. Moreover, it is well known that the water sorption isotherm for $\mathrm{PVOH}$ deviates from linearity towards higher values (Kulagina et al., 2007). The $\mathrm{PVOH}^{*}$ sample had significantly higher values $(p>0.05)$ than $\mathrm{PVOH}$ at all the humidities tested. These differences were greater at the lowest humidities tested. The reduction in crystallinity induced by crosslinking as indicated by DSC and ATR analysis is one of the causes of this effect. At $70 \% \mathrm{RH}$, the permeability is still higher but much closer to the original $\mathrm{PVOH}$ permeability.

Table 7.3. Water vapor permeability values of $\mathrm{PVOH}$-based materials.

\begin{tabular}{lcccc}
\hline \multicolumn{5}{c}{ Table 7.3. Water vapor permeability values of PVOH-based materials. } \\
\cline { 2 - 5 } & \multicolumn{4}{c}{$10^{16} . \mathrm{WVP}\left(\mathrm{kg} \cdot \mathrm{m} / \mathrm{m}^{2} . \mathrm{s} . \mathrm{Pa}\right)$} \\
\cline { 2 - 5 } & $\mathrm{RH} 35 \%$ & $\mathrm{RH} 50 \%$ & $\mathrm{RH} 60 \%$ & $\mathrm{RH} 70 \%$ \\
\hline \hline PVOH & $6.0 \pm 0.6 \mathrm{~b}, \mathrm{x}$ & $5.3 \pm 0.6 \mathrm{c}, \mathrm{x}$ & $15.4 \pm 0.6 \mathrm{c}, \mathrm{y}$ & $132.5 \pm 2.9 \mathrm{c}, \mathrm{z}$ \\
\hline PVOH $^{*}$ & $9.7 \pm 0.6 \mathrm{c}, \mathrm{x}$ & $8.6 \pm 0.6 \mathrm{~d}, \mathrm{x}$ & $45.7 \pm 2.9 \mathrm{~d}, \mathrm{y}$ & $142.8 \pm 5.7 \mathrm{~d}, \mathrm{z}$ \\
(PVOH.CD) $^{*}$ & $2.8 \pm 1.1 \mathrm{a}, \mathrm{x}$ & $3.4 \pm 0.6 \mathrm{~b}, \mathrm{x}$ & $8.6 \pm 0.6 \mathrm{a}, \mathrm{y}$ & $99.9 \pm 2.8 \mathrm{~b}, \mathrm{z}$ \\
PVOH $^{*}$.CD & $2.3 \pm 0.3 \mathrm{a}, \mathrm{x}$ & $1.7 \pm 0.3 \mathrm{a}, \mathrm{x}$ & $6.8 \pm 0.6 \mathrm{a}, \mathrm{y}$ & $42.8 \pm 2.8 \mathrm{a}, \mathrm{z}$ \\
PVOH.CD* $^{*}$ & $8.6 \pm 0.6 \mathrm{c}, \mathrm{x}$ & $7.8 \pm 0.6 \mathrm{~d}, \mathrm{x}$ & $12.9 \pm 0.3 \mathrm{~b}, \mathrm{y}$ & $131.4 \pm 2.8 \mathrm{c}, \mathrm{z}$
\end{tabular}

$a, b, c, \ldots$ indicate significant differences among the values of permeability at the same $\mathrm{RH}$. 
$x, y, z, \ldots$ indicate significant differences among the values of permeability of a sample at different values of $\mathrm{RH}$.

The intercatenary bonds reduced chain mobility and swelling of the material, counterbalancing the observed effect of the more amorphous structure. Among the composites, the PVOH.CD* sample presented a very similar permeability profile to that of $\mathrm{PVOH}$. The manufacturing process of this particular sample (casting of $\mathrm{PVOH}$ film and addition of the glyoxal/ $\beta C D$ aqueous solution) might be responsible for this result. The other composites presented improved water barrier properties at all humidities. The incorporation of a substance with a less hydrophilic character than the polymer reduces water sorption and swelling of the composite. This effect, combined with the previously mentioned crosslinking action, is responsible for these improvements.

\subsubsection{Oxygen permeability}

Gas permeability, especially oxygen, is also a key parameter for a packaging material. Permeation values were therefore determined for all samples at three humidities, owing to the $\mathrm{RH}$ effect on the barrier properties of this hydrophilic polymer. The results are included in Table 7.4. As expected, the water vapor permeability increases with $\mathrm{RH}$ for all samples as a consequence of the previously mentioned plasticization effect. This result is in agreement with permeation values of pure PVOH films (Aucejo et al., 2000). Water molecules adsorbed by the polymer interact with the hydroxyl groups of the polymer and deteriorate intra- and intermolecular hydrogen bonds, facilitating mobility of the polymer chains and diffusion of the molecules of oxygen.

Table 7.4. Oxygen Permeability Values of $\mathrm{PVOH}$-based materials.

\begin{tabular}{|c|c|c|c|}
\hline \multicolumn{4}{|c|}{ Oxygen Permeability $10^{21} \cdot \mathrm{PO}_{2}\left(\mathrm{Kg} \cdot \mathrm{m} /\left(\mathrm{m}^{2} . \mathrm{s} . \mathrm{Pa}\right)\right.$} \\
\hline & RH 50 & RH 75 & RH90 \\
\hline $\mathrm{PVOH}^{\star}$ & $5.4 \pm 1.0 \mathrm{a}, \mathrm{x}$ & $15.3 \pm 0.6$ a,y & $595.6 \pm 24.1 \mathrm{a}, \mathrm{z}$ \\
\hline
\end{tabular}




\begin{tabular}{lccc} 
(PVOH.CD)* & $9.6 \pm 1.1 \mathrm{~b}, \mathrm{x}$ & $38.3 \pm 2.5 \mathrm{bc}, \mathrm{y}$ & $1791.9 \pm 5.1 \mathrm{c}, \mathrm{z}$ \\
PVOH $^{*} . \mathrm{CD}$ & $8.8 \pm 0.1 \mathrm{~b}, \mathrm{x}$ & $40.7 \pm 0.7 \mathrm{c}, \mathrm{y}$ & $1521.6 \pm 88.9 \mathrm{~b}, \mathrm{z}$ \\
PVOH.CD* & $9.3 \pm 1.3 \mathrm{~b}, \mathrm{x}$ & $37.5 \pm 3.4 \mathrm{bc}, \mathrm{y}$ & $1660.5 \pm 44.2 \mathrm{bc}, \mathrm{z}$ \\
\hline PVOH & $3.6 \pm 1.2 \mathrm{a}, \mathrm{x}$ & $28.4 \pm 4.7 \mathrm{~b}, \mathrm{y}$ & $2111.6 \pm 101.4 \mathrm{~d}, \mathrm{z}$ \\
PVOH.CD & $19.8 \pm 2.4 \mathrm{c}, \mathrm{x}$ & $388.7 \pm 15.1 \mathrm{~d}, \mathrm{y}$ & $8066.7 \pm 162.4 \mathrm{e}, \mathrm{z}$ \\
\hline
\end{tabular}

$a, b, c, d, \ldots$ indicate significant differences among the values of permeability at the same $\mathrm{RH} ; \mathrm{x}, \mathrm{y}, \mathrm{z}, \ldots$ indicate significant differences among the values of permeability of the same sample at different values of $\mathrm{RH}$.

The generation of intermolecular chemical bonds in $\mathrm{PVOH}$ reduced molecular mobility and, subsequently, oxygen diffusivity. For this reason, $\mathrm{PVOH}^{*}$ presented better oxygen barrier characteristics than untreated PVOH. Table 4 also shows that the incorporation of cyclodextrins increased the permeability to oxygen of the composite films. The presence of the cavity of the molecules of cyclodextrins can facilitate diffusion of oxygen molecules in the polymer matrix. Nevertheless, the crosslinked composite films are more efficient barriers than the untreated composite one.

\subsection{Cholesterol scavenger results}

As mentioned in the introduction, one of the main applications of $\beta C D$ s in food and pharmaceutical applications is the formation of inclusion complexes for: a) the protection of a sensitive ingredient, or b) the extraction of an undesired component. In this work, the potential use of the composites developed in the reduction of the cholesterol content of foods was explored - specifically, in milk. Table 7.5 shows the results obtained for the various materials. Untreated material films could not be analyzed since they lose their integrity as a result of exposure to milk. $\mathrm{PVOH}^{\star}$ films, used as controls, did not present any significant cholesterol retention during storage time. The low chemical compatibility between the film and the fatty molecule is probably responsible for this result. 
Table 7.5. Cholesterol concentration ( $\mathrm{mg} / \mathrm{L}$ ) and \% reduction of cholesterol in milk exposed to $\mathrm{PVOH}$ materials at days 2 and 7 at $23^{\circ} \mathrm{C}$.

\begin{tabular}{|c|c|c|c|c|c|}
\hline & \multicolumn{5}{|c|}{ Day 2} \\
\hline & Milk & $\overline{\text { PVOH}^{\star}}$ & $\overline{(\mathrm{PVOH} . \mathrm{CD})^{\star}}$ & "PVOH*.CD & "PVOH.CD* \\
\hline Cholest. & $151.3 \pm 7.2 \mathrm{~b}, \mathrm{x}$ & $148.43 \pm 1.06 b, x$ & $141.94 \pm 1.77 \mathrm{a}, \mathrm{x}$ & $141.47 \pm 0.61 \mathrm{a}, \mathrm{y}$ & $142.16 \pm 1.4 \mathrm{a}, \mathrm{y}$ \\
\hline \multirow[t]{3}{*}{$\%$ Reduct. } & & $1.90 \pm 0.7$ & $6.19 \pm 1.17$ & $6.50 \pm 0.40$ & $6.04 \pm 0.92$ \\
\hline & \multicolumn{5}{|c|}{ Day 7} \\
\hline & "Milk & $\overline{\mathrm{PVOH}^{\star}}$ & $\overline{(P V O H . C D)^{\star}}$ & 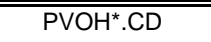 & PVOH.CD* \\
\hline Cholest. & $151.3 \pm 7.2 \mathrm{c}, \mathrm{x}$ & $147.76 \pm 1.65 \mathrm{c}, \mathrm{x}$ & $138.26 \pm 3.12 b, x$ & $136.15 \pm 2.48 a b, x$ & $130.69 \pm 2.1 \mathrm{a}, \mathrm{x}$ \\
\hline \% Reduct. & & $2.34 \pm 1.09$ & $8.62 \pm 2.06$ & $10.01 \pm 1.64$ & $13.62 \pm 1.39$ \\
\hline
\end{tabular}

$a, b, c, \ldots$ indicate significant differences among the values of the same day between samples. $x, y, \ldots$ indicate significant differences among the values of the same sample at different days.

On the other hand, the immersion of $\beta C D$-containing PVOH films in whole milk reduced the cholesterol content by the formation of inclusion complexes. At day 2, (PVOH.CD)* reduced the cholesterol concentration by $6.2 \%$. After 7 days of storage, the amount retained by the film increased slightly (6.5\%), although the difference is not significant. $\mathrm{PVOH}^{*} . \mathrm{CD}$ and $\mathrm{PVOH} . \mathrm{CD}^{*}$ samples presented a similar reduction at day 2 , but at day 7 the reduction was significantly higher, between 10 and $15 \%$. (PVOH.CD)* presented severe swelling, increasing the film thickness by $300 \%$. This large water retention produced a strong plasticization of the polymeric structure, allowing fast diffusion of the cholesterol molecules in the structure.

Also, $\beta C D$ molecules presented higher mobility, making possible the formation of cholesterol/ $\beta C D 1 / 2$ and $1 / 3$ inclusion complexes. In the other two samples the lesser degree of swelling produced a lesser plasticization of the polymer and, as a consequence, a slower diffusion of the cholesterol molecules in the polymer matrices. Also, a lesser number of $1 / 2$ and $1 / 3$ inclusion complexes increases the number of available $\beta C D$ molecules, increasing the final cholesterol reduction. 


\section{CONCLUSIONS}

Water resistant polyvinyl alcohol films containing $\beta C D$ s were successfully obtained thanks to the crosslinking action of glyoxal, although the efficiency of the immobilization was dependent on the crosslinking procedure, $\mathrm{PVOH}^{\star} . \mathrm{CD}$ and $\mathrm{PVOH} . \mathrm{CD}^{*}$ being the films with the best properties in terms of glyoxal migration, immobilization of $\beta C D$ s, and barrier properties. Moreover, these materials exhibited promising cholesterol scavenging activities. The materials were tested for their potential application as cholesterol scavengers in active packaging. The films crosslinked after the addition of CDs were more efficient.

\section{ACKNOWLEDGEMENTS}

The authors acknowledge the financial support of the Spanish Ministry of Science and Innovation, projects AGL2006-02176, AGL2009-08776 and FunC-Food CSD2007-00063, and the C. L-d-D fellowship (FPU program). Karel Clapshaw provided assistance with the English language text.

\section{REFERENCES}

Aucejo, S., Catala, R., Gavara, R., (2000). Interactions between water and EVOH food packaging films. Food Science and Technology International 6(2), 159-164.

Cevallos, P.A.P., Buera, M.P., Elizalde, B.E., (2010). Encapsulation of cinnamon and thyme essential oils components (cinnamaldehyde and thymol) in beta-cyclodextrin: Effect of interactions with water on complex stability. Journal of Food Engineering 99(1), 70-75.

Code of Federal Regulations, (2001a). Title 21: Food and Drugs. Chapter I - Food and drug aministration. Department of health and human services. Subchapter B - Food for human consumption. Part 177 - Indirect food additives: polymers.

Code of Federal Regulations, (2001b). Title 21:Food and Drugs. Chapter I - Food and drug administration. Department of health and human services. Subchapter B Food for human consumption. Part 176 - Indirect food additives: paper and paperboard components. 
Comini, S., Mentink, L., (1994). Process for refining mixtures resulting from treatment of fatty substances with cyclodextrin and containing complexes of cyclodextrin with fatty acid type lipophilic compounds. Roquette Freres, France, United States.

De Prisco, N., Immirzi, B., Malinconico, M., Mormile, P., Petti, L., Gatta, G., (2002). Preparation, physico-chemical characterization, and optical analysis of polyvinyl alcohol-based films suitable for protected cultivation. Journal of Applied Polymer Science 86(3), 622-632.

DeMerlis, C.C., Schoneker, D.R., (2003). Review of the oral toxicity of polyvinyl alcohol (PVA). Food and Chemical Toxicology 41(3), 319-326.

El-Kader, K., Hamied, S.F.A., Mansour, A.B., El-Lawindy, A.M.Y., El-Tantaway, F., (2002). Effect of the molecular weights on the optical and mechanical properties of poly(vinyl alcohol) films. Polymer Testing 21(7), 847-850.

European Economic Community, (1989). Council Directive of 21 December 1988. Official Journal European Community 32((L40)), 38-44.

European Economic Community, (1990). Council Directive 90/128/EEC of 23 February 1990, Official Journal European Community, pp. 26-47.

Fletouris, D.J., Botsoglou, N.A., Psomas, I.E., Mantis, A.I., (1998). Rapid determination of cholesterol in milk and milk products by direct saponification and capillary gas chromatography. Journal of Dairy Science 81(11), 2833-2840.

Garde, J.A., Catala, R., Gavara, R., (1998). Global and specific migration of antioxidants from polypropylene films into food simulants. Journal of Food Protection 61(8), 1000-1006.

Gohil, J.M., Bhattacharya, A., Ray, P., (2006). Studies on the crosslinking of Poly (vinyl alcohol). Journal of Polymer Research 13, 161-169.

Grob, K., Pfenninger, S., Pohl, W., Laso, M., Imhof, D., Rieger, K., (2007). European legal limits for migration from food packaging materials: 1 . Food should prevail over simulants; 2. More realistic conversion from concentrations to limits per surface area. PVC cling films in contact with cheese as an example. Food Control 18(3), 201-210.

Hernandez-Munoz, P., Kanavouras, A., Villalobos, R., Chiralt, A., (2004). Characterization of biodegradable films obtained from cysteine-mediated polymerized gliadins. Journal of Agricultural and Food Chemistry 52(26), 78977904.

Jang, M.S., Czoschke, N.M., Lee, S., Kamens, R.M., (2002). Heterogeneous atmospheric aerosol production by acid-catalyzed particle-phase reactions. Science 298(5594), 814-817.

Kelly, C.M., DeMerlis, C.C., Schoneker, D.R., Borzelleca, J.F., (2003). Subchronic toxicity study in rats and genotoxicity tests with polyvinyl alcohol. Food and Chemical Toxicology 41(5), 719-727.

Kulagina, G.S., Chalykh, A.E., Gerasimov, V.K., Chalykh, K.A., Puryaeva, T.P., (2007). Sorption of water by poly(vinyl alcohol). Polymer Science Series A 49(4), 425-432.

Kusumocahyo, S.P., Kanamori, T., Sumaru, K., Iwatsubo, T., Shinbo, T., (2004). Pervaporation of xylene isomer mixture through cyclodextrins containing polyacrylic acid membranes. Journal of Membrane Science 231(1-2), 127-132. 
Lopez-de-Dicastillo, C., Gallur, M., Catala, R., Gavara, R., Hernandez-Munoz, P., (2010). Immobilization of beta-cyclodextrin in ethylene-vinyl alcohol copolymer for active food packaging applications. Journal of Membrane Science 353(1-2), 184191.

López de Dicastillo, C., Catala, R., Gavara, R., Hernandez-Munoz, P., (2011). Food applications of active packaging $\mathrm{EVOH}$ films containing cyclodextrins for the preferential scavenging of undesirable compounds. Journal of Food Engineering , in press.

Lue, S.J., Peng, S.H., (2003). Polyurethane (PU) membrane preparation with and without hydroxypropyl-beta-cyclodextrin and their pervaporation characteristics. Journal of Membrane Science 222(1-2), 203-217.

Mansur, H.S., Sadahira, C.M., Souza, A.N., Mansur, A.A.P., (2008). FTIR spectroscopy characterization of poly (vinyl alcohol) hydrogel with different hydrolysis degree and chemically crosslinked with glutaraldehyde. Materials Science \& Engineering $C$ Biomimetic and Supramolecular Systems 28(4), 539-548.

Mavric, E., Wittmann, S., Barth, G., Henle, T., (2008). Identification and quantification of methylglyoxal as the dominant antibacterial constituent of Manuka (Leptospermum scoparium) honeys from New Zealand. Molecular Nutrition \& Food Research 52(4), 483-489.

Reineccius, T.A., Reineccius, G.A., Peppard, T.L., (2002). Encapsulation of flavors using cyclodextrins: Comparison of flavor retention in alpha, beta, and gamma types. Journal of Food Science 67(9), 3271-3279.

Soares, R.M.D., Soldi, V., (2010). The influence of different cross-linking reactions and glycerol addition on thermal and mechanical properties of biodegradable gliadinbased film. Materials Science \& Engineering C-Materials for Biological Applications 30(5), 691-698.

Szente, L., Szejtli, J., (2004). Cyclodextrins as food ingredients. Trends in Food Science \& Technology 15(3-4), 137-142.

Touil, S., Palmeri, J., Tingry, S., Bouchtalla, S., Deratani, A., (2008). Generalized dualmode modelling of xylene isomer sorption in polyvinylalcohol membranes containing alpha-cyclodextrin. Journal of Membrane Science 317(1-2), 2-13.

Weigel, K.U., Opitz, T., Henle, T., (2004). Studies on the occurrence and formation of 1,2-dicarbonyls in honey. European Food Research and Technology 218(2), 147151.

Xiao, Y.C., Chung, T.S., (2007). Functionalization of cellulose dialysis membranes for chiral separation using beta-cyclodextrin immobilization. Journal of Membrane Science 290(1-2), 78-85.

Yu, E.K.C., (1988). Novel decaffeination process using cyclodextrins. Applied Microbiology and Biotechnology 28(6), 546-552. 


\section{CONCLUSIONES}




\section{CONCLUSIONES}

1. Se han obtenido películas extruidas de EVOH con los antioxidantes naturales quercitina, catequina y extracto de té verde. Las películas fueron flexibles y $\sin$ discontinuidades, transparentes y coloreadas. Como consecuencia del tratamiento térmico recibido en el procesado se produjo una reducción en el contenido de antioxidante final en el polímero de entre un 10 a un 30\%, dependiendo del agente activo.

2. También se ha conseguido desarrollar películas de EVOH con ácido ascórbico, ácido ferúlico, quercitina y extracto de verde mediante la técnica de disolución/evaporación. Las películas fueron flexibles y con excelentes propiedades ópticas y retuvieron la práctica totalidad de la capacidad antioxidante nominal.

3. El estudio de las propiedades térmicas de los materiales obtenidos reveló que la adición de los antioxidantes mejora la estabilidad térmica del polímero, especialmente en los materiales desarrolladas por extrusión. No se observaron cambios relevantes ni en la cristalinidad de las películas ni en la temperatura de transición vítrea.

4. La incorporación de antioxidantes en las películas de EVOH no da lugar a cambios sensibles en sus propiedades barrera frente a vapor de agua y oxígeno. En general, a baja humedad relativa, se obtuvieron menores valores de permeabilidad al vapor de agua y al oxígeno, principalmente en las películas obtenidas por extrusión. A elevada humedad relativa, la presencia de antioxidantes con baja afinidad por el agua, produce una reducción en la permeabilidad al agua de las películas, observándose el efecto contrario en las películas que incluyeron los ácidos ascórbico y 
ferúlico. La permeabilidad al oxígeno a humedad relativa alta presenta este mismo comportamiento.

5. La liberación de los antioxidantes desde el EVOH a los diferentes simulantes se desarrolla por un proceso de transferencia de masa cuya extensión está gobernada por un equilibrio de partición, siendo por tanto dependiente de la concentración de antioxidante presente en las películas y de la solubilidad del agente en el medio simulante. Así, la liberación de los flavonoides catequina y quercitina es superior conforme aumenta el contenido alcohólico del simulante. El análisis por HPLC mostró que los componentes del extracto de té verde que se liberan varían con el tipo de simulante alimentario empleado; en simulantes acuosos destaca la presencia de ácido gálico mientras que en medio alcohólico hay una relevante presencia de catequinas, responsables del $70 \%$ de la elevada actividad antioxidante observada en este simulante. En las películas que incorporan ácido ascórbico, la liberación fue superior en el simulante acuoso.

6. El seguimiento de la liberación mostró que el proceso cumple las leyes de Fick y que queda controlado por la difusividad de los agentes en la matriz polimérica. Los valores del coeficiente de difusión indicaron que el proceso es más rápido en etanol, siendo éste el disolvente que más plastifica al EVOH. En todos los casos los valores obtenidos para todos los agentes indican que los materiales están severamente plastificados y no se comportan como materiales de alta barrera.

7. El estudio de la actividad antioxidante frente a radicales hidroxilo en estado vapor de las películas obtenidas por extrusión y sus aplicaciones con cacahuetes fritos demostró la eficacia de dichas películas para reducir la oxidación sin necesidad de un contacto directo con el alimento. 
8. Según los resultados derivados de los análisis de índice de peróxidos y de TBARS, todas las películas desarrolladas por casting presentaron actividad antioxidante en su aplicación para el envasado de sardina fresca salada, siendo especialmente efectivas las películas con extracto de té verde.

9. Se han obtenido satisfactoriamente películas de $\mathrm{EVOH}$ con $\beta$-ciclodextrinas mediante extrusión, utilizando glicerol como agente que facilita la incorporación y dispersión en la matriz polimérica. Los materiales presentaron aglomerados de ciclodextrina y una reducción en la cristalinidad de la matriz que afectaron a las propiedades barrera con un aumento en los valores de permeabilidad.

10. Se han desarrollado películas de $\mathrm{PVOH} \operatorname{co} \beta C D$ por el método de extensión/evaporación usando glioxal como agente entrecruzante para evitar la redisolución del polímero y mejorar la inmovilización de la ciclodextrina. Las películas mostraron mayores valores de migración en comparación con las películas de EVOH y también un aumento en la permeabilidad a gases y al agua, atribuibles a la elevada proporción de oligosacáridos.

11. Las películas de EVOH con ciclodextrinas presentaron una importante actividad atrapadora de volátiles en el espacio cabeza resultantes de la oxidación de cacahuetes envasados con estas películas.

12. En los ensayos realizados con leche entera, las películas de PVOH y EVOH presentaron una capacidad de retención de colesterol significativa, siendo las de $\mathrm{EVOH}$ con mayor concentración de ciclodextrinas las que presentaron los mejores resultados. 
5. ANEJOS 
Journal of Membrane Science 353 (2010) 184-19

Contents lists available at ScienceDirect

\begin{tabular}{|c|c|c|}
\hline$\frac{1}{5}$ & $\begin{array}{l}\text { Contents lists available at ScienceDirect } \\
\text { Journal of Membrane Science } \\
\text { journal homepage: www.elsevier.com/locate/memsci }\end{array}$ & 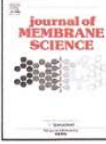 \\
\hline
\end{tabular}

Immobilization of $\beta$-cyclodextrin in ethylene-vinyl alcohol copolymer for active food packaging applications

Carol López-de-Dicastillo ${ }^{\mathrm{a}}$, Miriam Gallur ${ }^{\mathrm{b}}$, Ramón Cataláa ${ }^{\text {, }}$, Rafael Gavara ${ }^{\mathrm{a}, *}$, Pilar Hernandez-Muñoz ${ }^{\mathrm{a}}$

2Packaging Lab, Instituto de Agroquimica y Tecnología de Alimentos, CSIC, Apdo, de correos 73, 46100 Bujassot, Spain
b IIIENE, Parque Tecnologico, c/Albert Einstein, 1, 46980 Paterna, Spain

A R T I CLE INFO

Article history:

Received 28 October 2009

23 December 2009

Accepted 15 February 2010
Available online 20 February 2010

Keywords:

$\beta$-Cyclodextrin
EVoH copolym

Extrusion

DSC

Retention of organic compounds

\begin{abstract}
A B S T R A C T
Current developments in active food packaging are focusing on incorporating agents into the polymeric package walls that will release or retain substances to improve the quality, safety and shelf-life of the lood. Because cyclodextrins are able to form inclusion complexes with various compounds, they are potential interest as agents to retain or scavenge substances in active packaging applications. In this $244 \%$ molar percentage of ethylene ( $\mathrm{EVOH} 44$ ) by using regular extrusion with glycerol as an adjuint Films with $10 \%, 20 \%$ and $30 \%$ of $\beta C D$ were flexible and transparent. The presence of the agent slightly increased the glass-transition temperature and the crystallinity percentage of the polymer, that is say, it induced some fragility and a nucleating effect. The water vapor, oxygen and carbon dioxide barner properties of the materials containing $\beta C D$ were determined and compared with those of the pure the presence of discontinuities in the matrix and to the internal cavity of the oligosaccharide. Also the in the food aroma was analyzed. The materials with $\beta C D$ preferentially sorbed apolar compounds such as terpenes. This characteristic could be useful in active packaging applications for preferentially retaining undesired apolar food components like hexanal or cholesteral.

O 2010 Elsevier B. A. All rights reserved.
\end{abstract}

\section{Introductio}

Active food packaging is one of the most dynamic emerging technologies that the food industry is investigating as an alternaacidication, dying che especially coming with other technologies such as map, wes, tion pulsed electric fields, high pressure treatments, etc [11, Active food packaging is defined as the technology in which the packaging system plays an active role in food preservation and quality during the marketing process. Examples of active packaging technologies include the use of oxygen scavengers, carbon dioxide or ethylen emitters and scavengers, ethanol releasers, amine or aldehyde scavengers, and antimicrobial or antioxidant agents.

In many present-day active packaging technologies the active agent is placed in the package with the food, in a small sachet, pa or device manufactured from a permeable material which allows

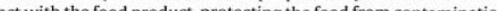

\footnotetext{
* Corresponding author. Tel.: + +34 963900022; fax: +34963636301.
}

0376-7388/5 - see front matter 02010 Elsevier B.V. All rights reservec or degradation. Active packaging developments are now focusing on incorporating the agents into the polymeric matrices which constitute the package walls; the resulting materials act by releasing substances which have a positive effect on the food or by retaining package

Because cyclodextrins (CDs) are able to form inclusion complexes with various compounds, they present a potential interest as agents to retain or scavenge substances such as odors, bitter compounds, lactose, cholesterol, etc, or to add aromas, colors, or functional ingredients whose release could enhance the quality of the packaged product and extend its shelf-life.

Cyclodextrins (CDs) are cyclic oligosaccharides composed of several glucose units ( 6 units in $\alpha \mathrm{CD}, 7$ units in $\beta C D$ or 8 units in $y C D)$ linked by $\alpha-(1-4)$ bonds, with a ring structure characterized by an hydrophilic external surface and an hydrophobic cavity. This unique structure enables $\mathrm{CD}$ s to form inclusion complexes, entrapping all or part of a 'guest' molecule inside their cavities. In aqueous

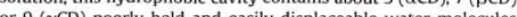
(2) aliphatic and aromatic compounds such as aroma compounds and lipophilic drugs. 


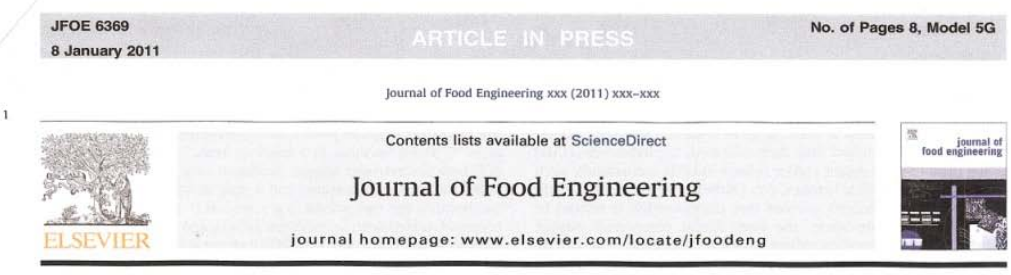

2 Food applications of active packaging EVOH films containing cyclodextrins

3 for the preferential scavenging of undesirable compounds

4 Carol López-de-Dicastillo, Ramón Catalá, Rafael Gavara *, Pilar Hernández-Muñoz

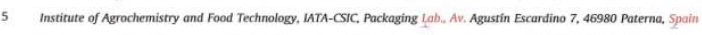

ARTICLE INFO

Arricle history:
Received 26 October 2010

Received 26 October 2010
Received in revised form 23 December 2010

Accepted 30 December 2000
Available online xxxx

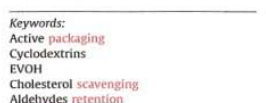

Cycodextrins
Evou
cholesterol scavent Aldehydes retention
Lid oxidation

A B S T R A C T

Novel ethylene-vinyl alcohol copolymer (EVOH) films containing beta-cyclodextrins ( $(\mathrm{BCD})$ with potenti

sired food components. The films were immersed on pastewrized milk and UHT milk and stored at 4 ald

$23^{\circ}$ C, respectively. The films con aing ing tion. achieving a 33 . to the films were involved in the formation of $\beta C D /$ /cholesterol inclusion complexes. In another set experiments, the films were used to reduce the presence of aldehydes (substances which develop as

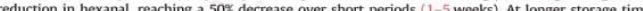
(10 weeks) the retention capacity of the developed films was exhausted and no differences were observed between the samples.

2011 Published by Elsevier Lt

38 1. Introduction

39 Active packaging is one of the emerging technologies which is (intense heat treastments, salting acidification, drying and chem cal preservation). Active packaging does more than simply provide a barrier to external detrimental factors, as the packaging syste plays an active role in food preservation and quality during the materials are designed to deliberately incorporate componing that release or absorb substances into or from the packaged food or the environment surrounding the food to extend the shelf-life or to maintain or improve the condition of the packaged food (Regrial developments are focusing on polymeric ms a tives whe release active agents (antimicrobials, antioxidants, etc) and/or retain substances such as oxygen, ethylene or water (Charles et a 2006: Flores et al., 2007) or undesired food components. While the scavengers used in the later applicacions are maliny based based on irreversible reactions, the present work studies the 15 e of cyclodextrins as potential scavengers.

Beta-cyclodextrin $(B C D)$ is an inexpensive enzyme-modified starch derivalive, composed of seven glucose

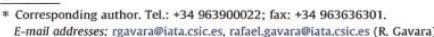
$\alpha(1 \rightarrow 4)$ glycosidic bonds in a cylindrically shaped cavity with cuter surface. The

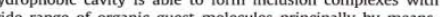
weak forces, su and hydrogen bonding. The use of cyclodextrins has increased annually in the food sector (Astray et al., 2009) mainly to remove cholesterol but also as carriers for molecular encapsulation of tiapublished describing their possibte applications in food pore bs and as food additives with different aims (Cravotto et al 2006. although their use is mainly based on the direct addition of the oligosaccharides to the liquid food, and precipitation and separatio size is compatible with filling the $\beta$-cyclodextrin cavity. In the literature it is possible to find cholesterol//BCD complexation ratios

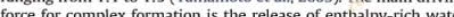
molecules from the cavity. Waser molecules are disphed by more hydrophobic guest molecules present in the solution to attain polar-apolar association and a decrease of cyclodextrin ring strai resulting in a more stable lower energy state. Cholesterol has a ndistinguishable from untreated products (Schroder and Baer. 1990).

0260-8774/5 - see front matter 02011 Published by Elsevier thit

Please cite this article in press as: Lopez-de-Dicastillo, C, et al. Food applications of active packaging EVOH films containing cyclodextrins for the preferMease cite this article in press as: Lopez-de-Dicastillo, C, et al. Food applications of active packaging EVOH films conta
ential scavenging of undesirable compounds. Journal of Food Engineering (2011), doi: 10.1016/j.jfoodeng.2010.12.033 
Journal of Agricultural and Food Chemistry

Development of new antioxidant active packaging films based on EVOH and green tea extract

\begin{tabular}{|r|l|}
\hline Journal: & Journal of Agricultural and Food Chemistry \\
\hline Manuscript ID: & Draft \\
\hline Manuscript Type: & Article \\
\hline Author: & n/a \\
\hline Complete List of Authors: & $\begin{array}{l}\text { Lopez-de-Dicastillo, Carol; IATA-CSIC, Packaging Lab } \\
\text { Nerin, Cristina; University of Zaragoza, Quimica Analitica } \\
\text { Alfaro, Pilar; University of Zaragoza, Quimica Analitica } \\
\text { Catalá, Ramón; IATA-CSIC, Packaging Lab } \\
\text { Gavara, Rafael; IATA-CSIC, Packaging Lab } \\
\text { Hernandez-Munoz, Pilar; IATA-CSIC, Packaging Lab }\end{array}$ \\
\hline & \\
\hline
\end{tabular}

SCHOLARONE

Manuscripts

ACS Paragon Plus Environment 
Improving the Antioxidant Protection of Packaged Food by Incorporating Natural Flavonoids into Ethylene-Vinyl Alcohol Copolymer (EVOH) Films

Carol lópez-de-Dicastillo, ${ }^{\dagger}$ José M. Alonso, ${ }^{\S}$ Ramón Catalá, ${ }^{\dagger}$ Rafael Gavara, ${ }^{*},{ }^{\dagger}$ and Pilar Hernández-Muñoz

'Packaging Lab, Instituto de Agroquimica y Tecnologia de Alimentos, CSIC, Avenida Agustin Escardin

Ethylene-vinyl alcohol copolymer (EVOH) films containing catechin or quercetin as antioxidant agents were successfully produced by extrusion. The addition of these bioactive compounds did not modify greatly their water and oxygen permeabilities, $T_{\mathrm{g}}$, or crystallinity but improved their therma resistance. Exposure of the films to different food simulants showed that both compounds were released, although the extent and kinetics of release were dependent on the type of food. In aqueous and alcoholic food simulants their release was greater in the case of the catechincontaining samples. Exposure of the films to isooctane and ethanol 95\% (fatty food simulants) provided controversial results; no release was observed in isooctane, whereas both bioactive compounds were extracted by ethanol due to their high solubility in alcohol and the plasticizing effect of ethanol on the polymer. Packaging applications of these films can improve food stability and provide a method for adding such bioactive compounds.

KEYWORDS: Flavonoids; active packaging; antioxidant; release; EVOH

\section{INTRODUCTION}

Oxidation processes are involved in most deterioration mepecially polymeric packages. To protect the contain term protection to the film, and a secondary antioxidant, which prection the and a secondary antioxidant, which the com por arylamines, organoshores and thiesters of synthetic that are approved by nato plastics in contact with foods. Nevertheles, nigregulations for additives and their degradation products into food during storage may change the sensory properties of the product they contain even lead to toxicity upon consumption. For these reasons, several research studies have focused on the development alternative polymer formulas with antioxidants that are considered to be food additives, such as BHT and BHA (4-6). However, the presence of these synthetic antioxidants in food questioned, owing to the potential risks, and strict statutory controls are required. The alternative that is being studied widel is the use of natural antioxidants, particularly tocopherol, pla extracts, and essenti Many phenolic che

are commonly found in plants reported to possess multiple biological effects,

${ }^{*}$ Corresponding author (phone +34-963900022; fax +34-96363630) e-mail rgavara@iata.csic.es). including antioxidant activity $(10)$. The principal antioxidan activity of these compounds is mainly as radical scavengers. However, many of the constituents of plant essential oils are volatile and difficult to use in conventional packaging manufacturing processes (extrusion, injection). Some initial studies have

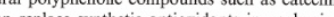
retection (11) To reduce oxide

idation in sensitive food products, the addition of antioxidants or the design of a suitable packaging technology are the two most common alternatives. Vacuum or modifiedtmosphere packaging combined with high-barrier packaging materials can limit the presence of oxygen, although it is no always completely and effectively eliminated because of a residual presence at the time of packing or because it permeates in from the exterior through the package wall. Moreover, some food products such as fresh red meat cannot be packaged without oxygen. Recently, other strategies have been considered including the us EU Re

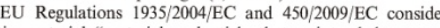
作 food" by the purposeful incorportion of componts released or purpoct or the environment surrounding the food $(16-18)$.

Highly reactive species such as free radicals, superoxide, hydro$\mathrm{xyl}$, and singlet oxygen are generated in food or in the surrounding atmosphere by different mechanisms and are involved in oxidatio reactions in lipids and other food components, contributing to 
Elsevier Editorial System(tm) for Food Chemistry

Manuscript Draft

\section{Manuscript Number:}

Title: Active antioxidant packaging films: development and effect on lipid stability of brined sardines

Article Type: Research Article (max 7,500 words)

Keywords: active packaging; antioxidant release; EVOH; sardines; lipid oxidation

Corresponding Author: Dr Rafael Gavara,

Corresponding Author's Institution: IATA-CSIC

First Author: Carol López-de-Dicastillo

Order of Authors: Carol López-de-Dicastillo; Joaquín Gómez-Estaca, PhD; Ramón Catalá, PhD; Rafael Gavara; Pilar Hernández-Muñoz, PhD

Abstract: Active antioxidant food packaging films were produced by the incorporation of ascorbic acid, ferulic acid, quercetin, and green tea extract into an ethylene vinyl alcohol copolymer (EVOH) matrix. The characterization of the thermal and barrier properties of the film developed showed that the addition of these bioactive compounds did not greatly modify their properties. However, the presence of ascorbic and ferulic acid resulted in a significant decrease in water vapor permeability, possibly due to the high affinity to water of these substances. Exposure of the films to various food simulants showed that the release from the films was dependent on the type of food simulant and the antioxidant incorporated: in the aqueous food simulant, materials containing ascorbic acid produced the largest release; in the fatty food simulant, quercetin and green tea extract presented the best performance. The efficiency of the films developed was determined by real packaging applications of brined sardines. The evolution of the peroxide index and the malondialdehyde content showed that, in general, the films improved sardine stability. Films with green tea extract offered the best protection against lipid oxidation. 

(

composites to scavenge undesirable food components

\begin{tabular}{|r|l|}
\hline Journal: & Journal of Agricultural and Food Chemistry \\
\hline Manuscript ID: & Draft \\
\hline Manuscript Type: & Article \\
\hline Autho Submitted by the & n/a \\
\hline Complete List of Authors: & $\begin{array}{l}\text { Lopez-de-Dicastillo, Carol; IATA-CSIC, Packaging Lab } \\
\text { Jordá-Beneyto, Maria; ITENE } \\
\text { Catalá, Ramón; IATA-CSIC, Packaging Lab } \\
\text { Gavara, Rafael; IATA-CSIC, Packaging Lab } \\
\text { Hernandez-Munoz, Pilar; IATA-CSIC, Packaging Lab }\end{array}$ \\
\hline & \\
\hline
\end{tabular}

SCHOLARONE

Manuscripts

ACS Paragon Plus Environment 
Elsevier Editorial System(tm) for Innovative Food Science and Emerging Technologies Manuscript Draft

Manuscript Number:

Title: Reducing oxidation of foods through antioxidant active packaging based on EVOH and natural flavonoids

Article Type: Research Article

Keywords: antioxidant; active packaging; quercetin; catechin; EVOH; sunflower oil; peanuts; radical species

Corresponding Author: Dr. Rafael Gavara,

Corresponding Author's Institution: IATA-CSIC

First Author: Carol López-de-Dicastillo

Order of Authors: Carol López-de-Dicastillo; Davinson Pezo; Cristina Nerín, Ph.D.; Ramón Catalá, Ph.D.; Rafael Gavara; Pilar Hernández-Muñoz, Ph.D.

Abstract: The development of antioxidant active packaging systems is attracting considerable attention as one of the preferred emerging technologies for reducing the incidence of lipid peroxidation. This work presents the use of ethylene-vinyl alcohol copolymer films containing two natural flavonoids, catechin and quercetin, to reduce the oxidation of food. In a series of experiments, these materials showed their ability to reduce the presence of hydroxyl radicals in the package headspace. Packaging fried peanuts in bags manufactured with these active films resulted in a large reduction in the presence of hexanal, a compound produced during peroxidation of the unsaturated fat in peanuts. The results indicated that the materials actively reduced the presence of radical oxidative species even though the antioxidants are not released into the food. On exposing sunflower oil to the films, the peroxide values obtained showed that the films actively protected the oil; because of the higher solubility of quercetin in this food product as well as the higher antioxidant capacity, the samples containing this flavonoid were more efficient. 